\title{
Hanford Surplus Facilities Program Plan Fiscal Year 1991
}

\author{
M. C. Hughes \\ R. K. Wahlen \\ R. A. Winship
}

Date Published

September 1990

Prepared for the U.S. Department of Energy Assistart Secrctary for Defense Programs

\footnotetext{
(2) Westinghouse Hanford Company Richland, Washington 99352 


\title{
HANFORD SURPLUS FACILITIES PROGRAM PLAN
}

FISCAL YEAR 1991

\author{
M. C. Hughes \\ R. K. Wahlen \\ R. A. Winship
}

\section{ABSTRACT}

The Hanford Surplus Facilities Program is responsible for the safe and cost-effective surveillance, maintenance, and decommissioning of surplus facilities at the Hanford Site. The management of these facilities requires a surveillance and maintenance program to keep them in a safe condition and development of a plan for ultimate disposition. Criteria used to evaluate each factor relative to decommissioning are based on the guidelines presented by the U.S. Department of Energy-Richland Operations Office, Environmental Restoration Division, and are consistent with the Westinghouse Hanford Company commitment to decommission the Hanford site retired facilities in the safest and most cost-effective way achievable. This document outlines the plan for managing these facilities to the end of disposition. 
WHC-EP-0231-3

\section{EXECUTIVE SUMMARY}

The Hanford Surplus Facilities Program (HSFP) is responsible for the safe and cost-effective surveillance, maintenance, and decommissioning of surplus facilities at the Hanford Site. The number of facilities in the program will vary from year to year in accordance with the demolition of some structures and the addition of other facilities that have been declared excess and are transferred to this program during the last year. There are 129* facilities listed in the current inventory. These facilities have been retired from programmatic use and, with the exception of a number of ancillary buildings, are contaminated with radioactive material. The majority of these facilities are located in the 100 and 200 Areas and include shutdown production reactors, chemical separations and processing plants, waste-handling facilities, and various support structures. The management of these facilities requires a surveillance and maintenance program to keep them in a safe condition, and development of a plan for ultimate disposition. This document outines the plan for managing these facilities to the end of disposition.

The surveillance and maintenance cost for these facilities is approximately $\$ 5$ million annually in FY 1991 values. This cost will vary, decreasing when facilities are decommissioned and increasing substantially if they are placed in a long-term protective storage mode.

The decommissioning costs of this program will total approximately $\$ 800$ million and are projected over a period of 30 years beginning in FY 1989.

\footnotetext{
*One facility was completed during fiscal year (FY) 1990, and 32 facilities were added with 13 others transferred to another program.
} 
This cost can vary significantly depending on the decommissioning alternative (e.g., in situ decommissioning, total dismantlement), regulatory requirements, and actual budget received per fiscal year.

The surveillance, maintenance, and decommissioning work will be accomplished by employees of the Westinghouse Hanford Company (Westinghouse Hanford) Hanford Restoration Operations (HRO), except in cases requiring specialists, such as divers or explosives experts. When specialties are required, the services will be contracted out under the direction of the HSFP.

The Westinghouse Hanford Management Control System is used for financial planning and scheduling work. Budget guidance is received annually from the U.S. Department of Energy (DOE), Office of Environmental Restoration and Waste Management. Projects and associated budgets and schedules are established based on this guidance. Project sitatus is monitored and reported monthly. Control procedures have been established for routine surveillance and services. Controls, which ensure compliance with regulations, are incorporated into the individual decommissioning project plans. 


\section{CONTENTS}

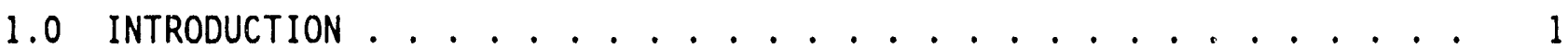

1.1 PURPOSE ......................... . . . . 1

1.2 SCOPE . . . . . . . . . . . . . . . . . . . . . 1

1.3 MAJOR SURPLUS FACILITIES MANAGEMENT OBJECTIVES . . . . . . . . 2

2.0 ORGANIZATIONAL STRUCTURE AND RESPONSIBILITIES . . . . . . . . . . 3

2.1 ORGANIZATION STRUCTURE . . . . . . . . . . . . . . 3

2.2 RESPONSIBILITIES ....................... . . . . . 3

2.2.1 U.S. Department of Energy-Richland Operations office. . 3

2.2.2 Westinghouse Hanford Company Environmental Division . . 3

2.2.3 Environmental Restoration Programs........... 3

2.2.4 Hanford Site Surplus Facilities Programs . . . . . . . . 3

2.2.5 Defense Waste Planning, Integration, and Budgets.... 5

2.2.6 Hanford Restoration Operations . . . . . . . . . . 5

3.0 BUDGETING AND PLANNING . . . . . . . . . . . . . . . . . . . . 7

4.0 SURPLUS FACILITIES MANAGEMENT PRDGRAM ASSUMPTIONS, CRITERIA, AND PRIORITIES

4.1 ASSUMPTIONS . . . . . . . . . . . . . . . . . . . . . . . . . . . 9

4.2 CRITERIA . . . . . . . . . . . . . . . . . . . . . . . . . 10

4.2.1 Criteria Used in Assessing Decommissioning

Alternatives................... 10

4.2.2 Environmental Protection Criteria . . . . . . . . 10

4.2.3 Safety Criteria .. . . . . . . . . . . . . 11

4.3 PROJECT PRIORITIES . . . . . . . . . . . . . . . . . 12

4.3.1 Prioritization Criteria . . . . . . . . . . . 12

4.3.2 Prioritization of Projects............ 13

5.0 WORK ELEMENTS . . . . . . . . . . . . . . . . . 15

5.1 GENERAL . . . . . . . . . . . . . . . . . . . 15

5.1.1 Program Management and Administration . . . . . . . 15

5.1.2 Surveillance and Maintenance . . . . . . . . . . . 15

5.1.3 Decommissioning Projects ............... 15

5.1.4 Underground Storage Tanks . . . . . . . . . . . 15

5.1.5 Asbestos Abatement ................. . 15

5.1.6 Reactor Support Facilities ............. . 16

6.0 CONTROL . . . . . . . . . . . . . . . . . . . . . . . . 17

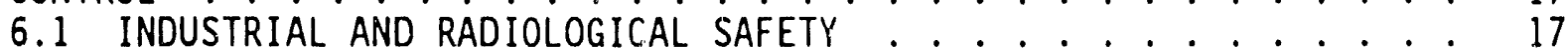

6.1.1 Industrial Safety . . . . . . . . . . . . . . . . 17

6.1.2 Radiological Safety ................. . 17

6.1.2.1 Management of Waste Generated during
Decontamination and Decommissioning...... . 21

6.1.2.2 Waste Left at the Site (Decommissioned
In Situ) . . . . . . . . . . . . 21

6.1.2.3 Allowable Residual Contamination Levels... . . 21

6.1.2.4 Application of the Allowable Residual
Contamination Limits Method . . . . . . . . 22

6.1.2.5 Release of Materials for Unrestricted Offsite
Use......................... 23

6.1.2.6 Disposition of Contaminated Equipment.... . 23 


\section{CONTENTS (continued)}

6.2 DISFOSITION OF NONRADIOACTIVE, HAZARDOUS MATERIAL . . . . . 25

6.3 QUALITY ASSURANCE . . . . . . . . . . . . . . 25

6.4 PROJECT MANAGEMENT AND CONTROL . . . . . . . . . . . . . 25

6.4.1 Cost and Schedule Performance Monitoring . . . . . . . 25

6.5 REGULATORY REQUIREMENTS .................. . . . 27

6.6 FACILITY ACCEPTANCE AND TRANSFER ........... 27

6.6.1 Facility Transfer and Acceptance Requirements . . . . . 27

6.6.2 Facility Transfer into the Program ........... 28

6.6.3 Facility Transfer out of the Program ......... 28

6.6.4 Identification and Description of Surplus

Facilities Questionnaire............ 29

6.6.5 Property Management . . . . . . . . . . . . . 29

7.0 DOCUMENTATION AND APPROVALS ................... 31

7.1 SURVEILLANCE AND MAINTENANCE GUIDELINES . . . . . . . . . . 31

7.2 DECOMMISSIONING PROJECT WORK . . . . . . . . . . . 31

7.3 LISTINGS OF HANFORD SITE FACILITIES ........... 31

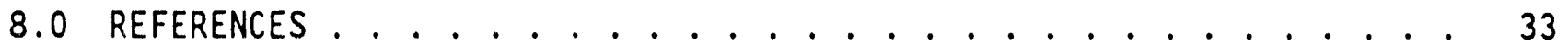
APPENDIXES:

A. WORK ELEMENTS ................... . . . . . . .

B. AREA SITE MAPS ..................... B-1

C. LONG-RANGE COST/SCHEDULE PROJECTION ............ 
WHC-EP-0231-3

\section{LIST OF FIGURES}

1 Organization Structure . . . . . . . . . . . . . . . 4

2 Rollup Process for Developing Cost Accounts . . . . . . . . . . 8

\section{LIST OF TABLES}

1 Regulatory Requirements . . . . . . . . . . . . . 18

2 Release Levels and Priorities for Decommissioned Facilities and Land Areas .. . . . . . . . . . . . . . . 20

3 Acceptable Surface Contamination Levelc for Materials Removed from the Site ................... . 24

4 Nonradioactive, Hazardous Materials Present in the Hanford Site Shutdown Facilities 


\section{LIST OF TERMS}

ACWP

ADM

ADS

ALARA

ARCL

BCWP

BCWS

CAA

CAM

CAP

CERCLA

CV

D\&D

DFDPO

DOE

DOE-RL

DOT

EA

EAC

Ecology

EIS

ERD

FDS

FY

HRO

HSFP

NEPA

PBR

PCB

PNI.

QA

RCRA

RI/FS

SFMP

SV

TEC

TRU

VAR

WAC

Westinghouse

Hanford actual cost of work performed action description memorandum activity data sheets

as low as reasonably achievable

allowable residual contamination limits

budget cost of work performed

budget cost of work scheduled

cost account authorizations

cost account manager

cost account $\mathrm{plans}$

Comprehensive Environmental Response, Compensation, and Liability Act

cost variance

decontamination and decommissioning

Defense Facilities Decommissioning Programs Office

U.S. Department of Energy

U.S. Department of Energy-Richland Operations Office

U.S. Department of Transportation

environmental assessment

estimate at completion

Washington State Department of Ecology

environmental impact statement

Environmental Restoration Division

Financial Data System

fiscal year

Hanford Restoration Operations

Hanford Surpius Facilities Program

National Environmental Policy Act

program business representative

polychlorinated biphenyl

Pacific Northwest Laboratory

Quality Assurance

Resource Conservation and Recovery Act

remedial investigation/feasibility study

surplus facilities maintenance program

schedule variance

total estimate cost

transuranic

variance analys is report

Washington Administrative Code

Westinghouse Hanford Company

$$
\text { xilxii }
$$


WHC-EP-0231-3

\section{HANFORD SURPLUS FACILITIES PROGRAM PLAN \\ FISCAL YEAR 1991}

\subsection{INTRODUCTION}

\subsection{PURPOSE}

Many IJ.S. Department of Energy (DOE)-owned nuclear facilities at the Hanford Sice that were used during the early nuclear energy programs have no current use and have been retired and declared excess. The majority of these facilities have residual radioactive contamination requiring surveillance, maintenance, and ultimate disposition.

This program plan identifies the work breakdown structure, cost, schedule, and priorities for decommissioning the surplus facilities at the Hanford Site. The plan also describes the activities of the Hanford Surplus Facilities Programs (HSFP) of Westinghouse Hanford Company (Westinghouse Hanford) in the management of these facilities to meet the objectives listed in Section 1.3 of this report and to comply with regulations set forth by the DOE directives.

\subsection{SCOPE}

This plan covers 129* separate retired facilities located on the Hanford Site. These facilities include large concrete and cement block structures used to house chemical separation processes, nuclear production reactors, support systems, storage tanks, and ancillary buildings.

The scope of this document includes the following increments of the overall program:

- Purpose, scope, and objectives

- Program organizational structure and responsibilities

- Budgeting and planning

- Assumptions and criteria

- Work elements

- Control.

*One facility was completed during fiscal year (FY) 1990, and 32 facilities were added with 13 others transferred to another program. 
WHC-EP-0231-3

\subsection{MAJOR SURPLUS FACILITIES MANAGEMENT OBJECTIVES}

The following items are the major objectives in the management of the surplus retired facilities.

- Continue maintenance and surveillance of the retired HSFP fac:liti?s in a safe, cost-effective, and environmentally sound manner pendinc decontamination and decommissioning (D\&D).

- Provide the planning and engineering necessary to ensure the efficient, cost-effective decommissioning of the HSFP retired facilities.

- Develop short- and long-range budgets and schedules, including identification of projects to complete decommissioning of all contaminated facilities within the program.

- Assess technical and economic feasibility of decommissioning and surveillance alternatives.

- Determine if there are any cost-effective reuses for shutdown facilities.

- Comply with the provisions of both state and federal environmental policies, and develop support documentation.

- Develop innovative, cost-effective decommissioning, surveillance, and asbestos abatement methods that comply with regulatory requirements for environmental and occupational safety.

- Decommission facilities in the safest and most cost-effective manner practicable.

- Maintain worker exposure to as low as reasonably achievable (ALARA) levels through the use of administrative or engineered controls.

- Review and update this program plan annuaily. 
WHC-EP-0231-3

\subsection{ORGANIZATIONAL STRUCTURE AND RESPONSIBILITIES}

\subsection{ORGANIZATION STRUCTURE}

A block diagram of the organization structure is presented in Figure 1.

\subsection{RESPONSIBILITIES}

\subsubsection{U.S. Department of Energy-Richland Operations Office}

The U.S. Department of Energy-Richland Operations Office (DOE-RL) Environmental Restoration Division (ERD) is responsible for the Envirciumental Restoration Program at Hanford.

\subsubsection{Westinghouse Hanford Company Environmental Division}

The Westinghouse Hanford Company Environmental Division has overall responsibility for planning, coordinating, and integrating the Westinghouse Hanford environmental activities. This includes the D\&D and surplus facilities management.

\subsubsection{Environmental Restoration Programs}

This program integrates the Environmental Restoration and Remedial Action Program with the Environmental Restoration-Decontamination and Decommissioning Program.

\subsubsection{Hanford Site Surplus Facilities Programs}

At the Hanford Site, the programmatic responsibility within the Westinghouse Hanford-Environmental Restoration Programs for the surveillance, maintenance, and decommissioning of surplus facilities is the HSFP. The HSFP establishes the cost, schedule, and technical baselines for individual projects, such as the 100 Area shutdown reactor facilities, and provides the project management for completing the work. The work acicivities relative to projects are completed by various functional organizations through a matrix management system. Performing organizations are assigned work by the Program Office using cost account authorizations (CAA) and cost account plans (CAP). Project status is reported to the Program Office using an earned-value system. The majority of decommissioning field work and engineering at the Hanford Site is performed by Hanford Restoration Operations (HRO). Subcontracted work is managed through the HSFP. (Rejer to Figure 1 for the organization structure.) 
Figure 1. Organization Structure.

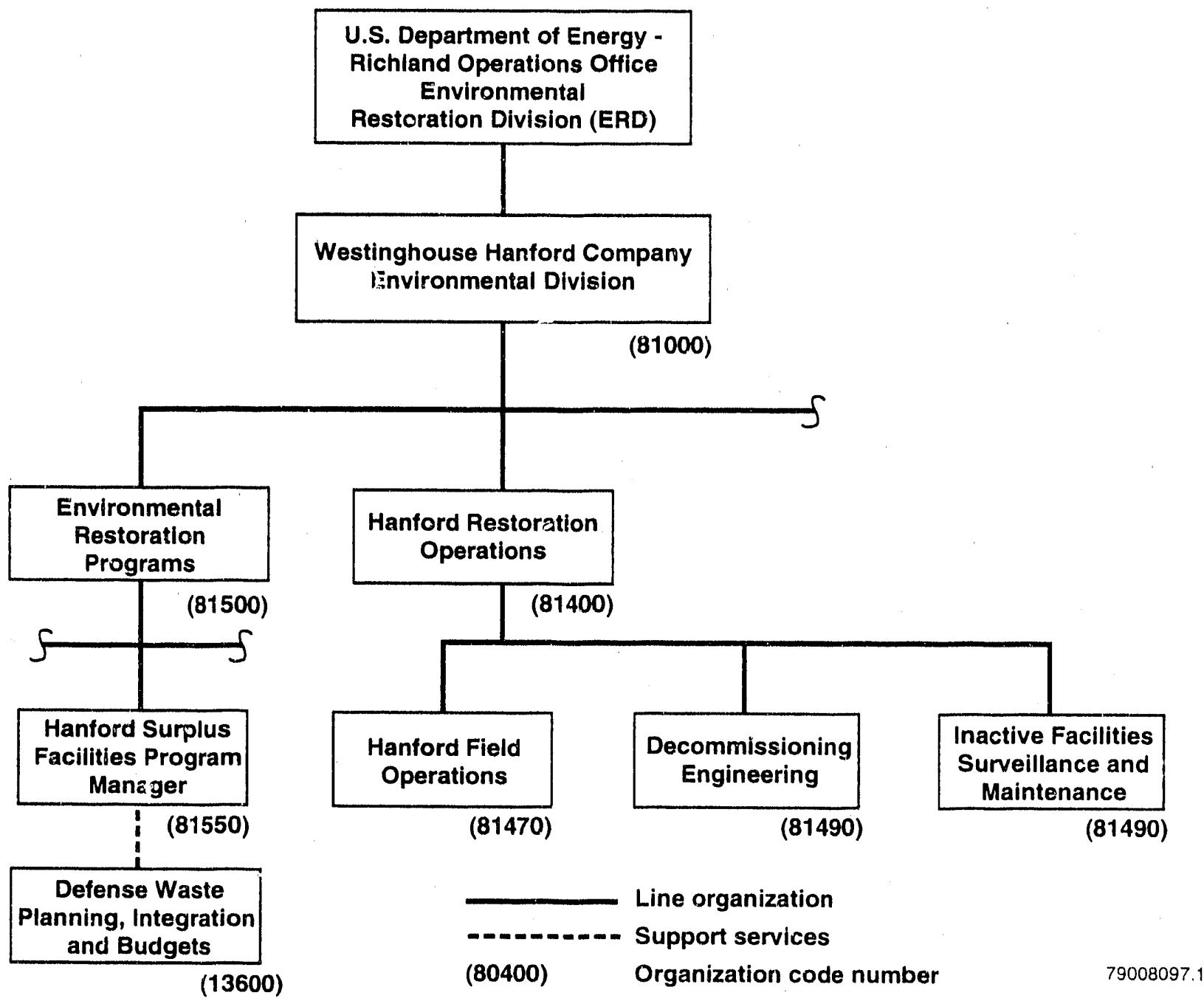




\subsubsection{Defense Waste Planning, Integration, and Budgets}

This office provides a full range of business management services for the Waste Management and Environmental Divisions. Some of the direct support services provided to the HSFP include the detailed budget development and the associated monitoring, analysis, and reporting relative to cost and schedule.

\subsubsection{Hanford Restcration Operations}

The HRO performs the necessary surveillance and maintenance, decommissioning and environmental restoration field operations on the Hanford Site, including the engineering act,ivities in support of these operations. The HRO alsn functions as iandlord and plant manager for all cortaminated surplus facilities and a selected number of inactive noncontaminated facilities. 
WHr.-EP-0231-3

\subsection{BUDGETING AND PLANNING}

The HSFP adheres to the guidelines and procedures set forth by the DOE-RL and Westinghouse Hanford with regard to the budgeting and planning of decontamination and decommissioning activities. Defined below are the processes followed by the HSFP in the development and preparation of detailed budgeting, planning, and scheduling of D\&D activities.

The HSFP obtains funding for the D\&D activities from the DOE-Office of Envirorimental Restoration and Waste Management. The HSFP receives detailed guidance from the DOE-RL Environmenta? Restoration Di ision.

The budgeting cycle (fiscal year +2 ) begins each fiscal year upon receipt of budget guidance current i ical year and (fiscal year +1 ) from DOE. Included in the guidance are funding levels and escalation and inflation assumptions for the outyears. The HSFP also has prenared Activity Data Sheets (ADS) in support of the Office of Environmental Restoration and Warte Management 5-year plan. The ADS provide details by major projects and support all other budget submittals. The ADSs are updated annually as par: of the 5-year planning effort.

The HSFP management initiates its detailed planning for the upcoming fiscal year during the first quarter of the current fiscal year. This planning begins by integrating guidance funding levels with long-range plan objectives and project priorities to derive a detailed list of projects for the year. The list is transmitted to HRO for Decommissioning Engineering to develop draft documents that detail the scope for the project. (These documents are known as "scoping" documents.) A project team (headed by the cognizant engineer, including a project coordinator, cost estimator, cost account manager (CAM), scheduler, and program business representative (PBR) prepares the detailed scoping documents. The estimator prepares a project cost estimate based on the scoping document. This estimate is reviewed by the project team and used as a tool for preparing CAAs, the detailed work schedules, and CAPs. This process is targeted for completion by mid-July of each fiscal year.

The CAAs are prepared by the activity manager and approved by the HSFP manager and the PBR. The CAAs are sent to the appropriate CAM to generate the CAPs. The CAMs are responsible for coordination with work package and task package development. The CAAs and CAPs are approved by the HSFP manager before initiating work October 1 of the fiscal year (see Figure 2).

The detailed planning and budgeting begin at the lowest level, the task package, where each task package manager provides the respective work package manager input into the development of the work package. The work package managers follow sequence by providing their input into the development of the cost accounts. This "rollup" process continues to the program level. These data are input into the Financial Data System (FDS) in a development mode until a consensus and approval of workscope and schedules by all responsible management have been achieved. Once the funded activities are approved and their total budget ties with the given funding parameters for the upcoming fiscal year, the planned activities are ready for monitoring and reporting of cost and schedule status information. 
WIC-EP-0231-3

Figure 2. Rollup Process for Developing Cost Accounts.

Activity

managers

Work package

managers

Task package

managers

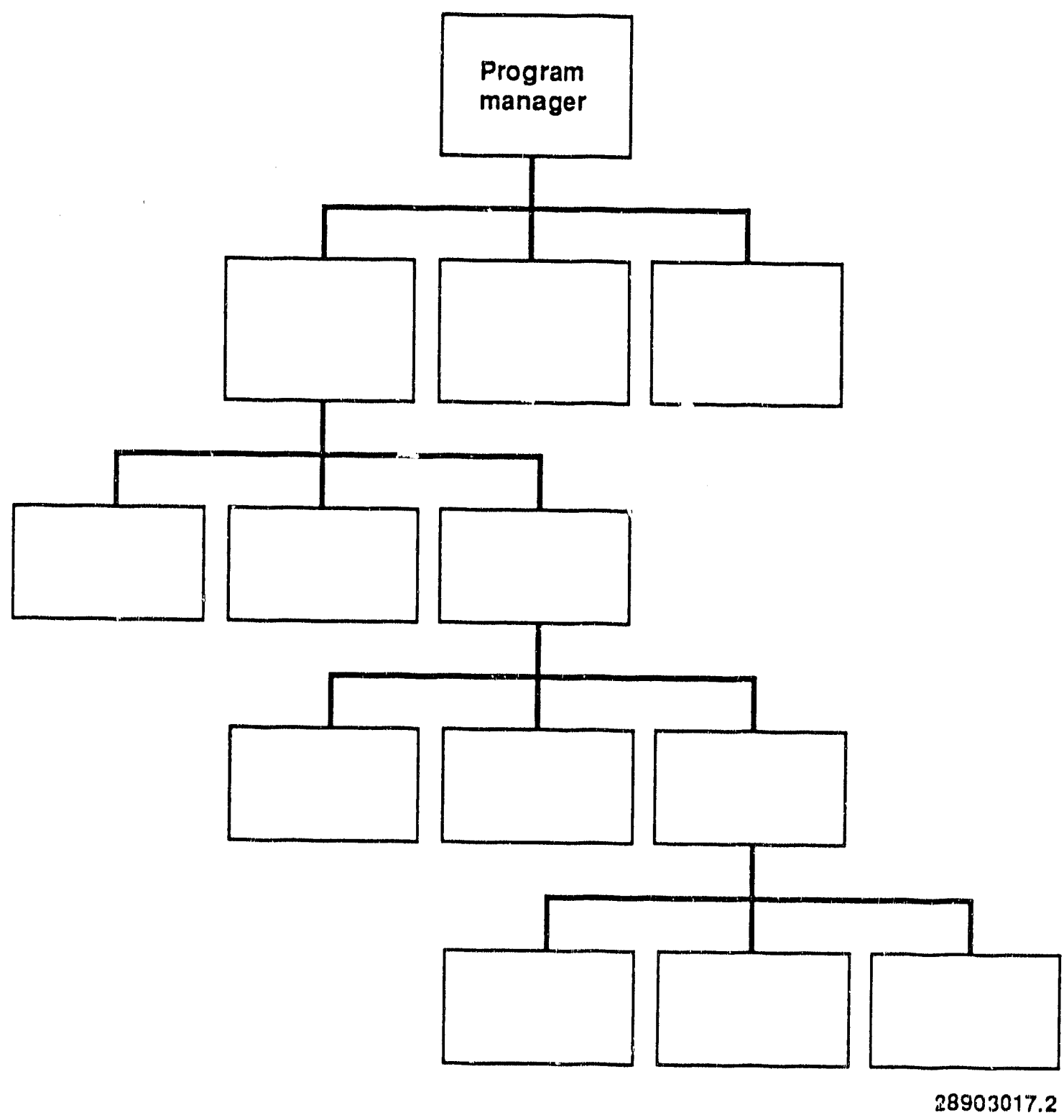


WHC-EP-0231-3

\subsection{SURPLUS FACILITIES MANAGEMENT PROGRAM ASSUAPTIJNS, CRITERIA, ANO PRIORITIES}

\subsection{ASSUAPTIONS}

The program costs, management, and technical strategies presented in this plan are based on the assumptions listed below. These assumptions are based on experience gained in previous surveillance, maintenance, and decommissionina work; engineering studies; and facility characterization.

The follewing assumptions are consistent with the guidance provided by the DOE-RL. A change in any of the assumptions would result in the need to reevaluate this plan. The HSFP assumptions are as follows:

- Surveiliance and maintenance recuirements affecting safety and the environment have the highest priority and $4: 111$ be funded ahead of any other program activity. Additional maintenance activities are supported relative to the potential health risk involved and cost effectiveness.

- Radiological dose rales to personnel and to members of the public will be controlled in accordance with DOE standards for radiation protection and will be reduced to ALARA levels.

- Hllowable residual contamination limits (ARCL) for in situ decommissioning will be calculated using the pathway analysis methodology as applicable.

- Future radiological and chemical potential characterization changes were not considered in the current overall decommissioning strategy. Estimated radionuclide inventories are based on the best data available when this plan was prepared.

- Radioactive wastes, transuranic (TRU), and mixed waste not decommissioned in situ will be handled in compliance with applicable DOE orders and with Westinghouse Hanford requirements.

- Material or equipment removed from the site and released for uncontrolled use will meet all radiological DOE requirements applicable at the time of removal.

- The annual budget is based on guidance received from DOE for the specific fiscal year. The outyear's annual budget also is based on DOE guidance and on completing all project work by FY 2017 . (See Appendix $C$ for cost and schedule.)

- The reactor facilities and 1 and they occupy can, if necessary, be controlled institutionally for a period of up to 100 years. Institutional control means the controlled use of a decommissioned site or area through regulation by local, county, state, or federal agencies. Because of radiological conditions, institutional control may include access control, minor maintenance and sur ieillance, and 
site-use restrictions. Institutional control starts when a facility is considered to be decommissioned and ends at 100 years, or any time within the 100-year period.

- The site terrain will be restored to as near-natural condition as practicable.

- The program plan work element schedule and cost are based on the one-piece removal alternative for the reactors. The 100 Area ancillaries and the 200 and 300 Area facilities, schedule, and cost are based on in situ decommissioning. A change to other alternatives will require a review and update of these schedules and costs.

\subsection{CRITERIA}

\subsubsection{Criteria Used in Assessing Decommissioning Alternatives}

The following factors are used to assess the relative merits of several candidate decommissioning methods to determine objectively the preferred alternatives:

- Dollar expenditure

- Public and occupational radiation exposure

- Manpower requirements

- Project duration

- Radioactive waste disposal volume

- Potential for reuse of equipment, material, and facility

- Time until site can be restored to a near-natural condition.

Criteria used to evaluate each factor are based on the guidelines presented by the DOE-RL and are consistent with the Westinghouse Hanford commitment to decommission the Hanford Site retired facilities in the safest and most cost-effective way achievable.

\subsubsection{Environmental Protection Criteria}

Before siarting any decommissioning work at the Hanford Site, Westinghouse Hanford, as a DOE-RL contractor, is required to comply with local, state, and federal environmental protection criteria. Compliance will require a review of all applicable regulations of the National Environmental Policy Act (NEPA), Comprehensive Environmental Response, Compensation, and Liability Act (CERCLA), Resource Conservation and Recovery Act (RCRA), and the Washington Administrative Code (WAC) for dangerous waste. The requirements of these regulations are of particular concern because of the range of 
WHC-EP-0231-3

environmental issues that may have to be addressed and because of the potential for significant impact on the decommissioning budget and schedule.

These processes will be implemented early in the planning stages to allow Westinghouse Hanford and the DOE-RL sufficient time to complete the necessary documentation. Depending on the proposed project, the DOE may specify one of two levels of NEPA documentation, including an environmental assessment (EA), and/or an environmental impact statement (EIS). The DOE may also prepare an action description memorandum (ADM). The ADM serves as a basis for deternination of the required level of NEPA documentation. In some cases, a specific action may be determined to be categorically excluded and therefore would not equire an EA or an EIS.

In conjunction with the specified NEPA process, the DOE may direct that a remedial investigation/feasibility study (RI/FS) be conducted to satisfy the requirements of the RCRA and CERCLA and/or those specified by the WAC on Dangerous Waste Regulations (Ecology 1987).

\subsubsection{Safety Criteria}

Until decommissioning is complete, routine maintenance and surveillance will be conducted on the shutdown facilities to maintain an industrial and radiological safe status and to correct any safety conditions found to be out of standard.

Completing the decommissioning work safely is of primary concern to Westinghouse Hanford. Accordingly, the guidelines presented in DOE Order 5481.1A (DOE-RL 1983) will be followed for all decommissioning work. This Order establishes specific safety criteria for all DOE activities, including decommissioning work, and requires safety analyses be prepared on all projects.

The safety analysis process consists of two parts. The first part is a preliminary safety analysis that becomes a part of the planning documentation for a specific decommissioning activity and determines the level of safety review and approval required to authorize the activity.

The second part of the safety analysis process is documented in the startup readiness review to authorize starting the decommissioning activity. Both the preliminary and final safety analyses will follow the Westinghouse Hanford requirements. The suggested format of both the preliminary and final safety analyses will discuss the following general headings as applicable to decommissioning:
1.0 Summary
2.0 Introduction
3. 0 Site Description
4.0 Facility and Process Description 


\subsection{Facility Description \\ 4.2 Process Description \\ 4.3 Waste Management \\ 4.4 Safety Features}

5.0 Design Criteria

6.0 Safety Analysis

\subsection{Safety Analysis Methodology \\ 6.2 Hazards Analysis \\ 6.3 Risk Assessment \\ 6.4 Summary}

7.0 Operational Safety Limits

8.0 References

Appendixes (as necessary)

\subsubsection{Quality Assurance}

The implementation of quality assurance criteria relative to Decontamination \& Decommissioning (D\&D) activates is outlined in 8 quality assurance plan. All line organizations performing D\&D work are responsible for ensuring quality work per the established criteria. In addition, the quality assurance organization provides an independent overview to ensure that the overall Hanford Surplus Facilities Program requirements are effectively implemented. The quality assurance organizations also review, assess, and verify the achievement of quality.

\subsection{PROJECT PRIORITIES}

\subsubsection{Prioritization Criteria}

Because of the large number of surplus facilities at the Hanford Site awaiting final disposition and the limited funds availabile to perform this work, decommissioning priorities must be set. Once pricrities are established, detailed costs and schedules that reflect these priorities can be developed with more accuracy.

The former Defense Facilities Decommissioning Programs office (DFDPO) established criteria to guide participating decommissioning contractors in determining project priorities and ranking (DOE-RL 1982). These criteria continues to be used until a new method of prioritization is developed. The six factors are listed below in order of priority assigned by DFDPO.

1. Legal and Safety Standards--The evaluation factor of greatest concern to DFDPO is legal or contractual obligations. Legal requirements generally pertain to the safety of the public, workers, and the environment. Priorities are assigned to ensure that the facilities in the program pose no uriacceptable safety risk. Surveillance and maintenance of surplus facilities in a safe 
condition (until a decommissioning project can be initiated) is considered to be the highest overall program priority.

2. Economic Impact of Delayed Versus Immediate Decommissioning-Consideration must be given to the tradeoff between the cost of continued maintenance and surveillance and the cost of final facility disposition. An economic analysis model that uses a monetary discounting technique to calculate the "present value" cost. for surveillance and maintenance, as well as for decommissioning, is used in this determination.

3. Health Risks of Delayed Decommissioning--The health risk to onsite personnel and the general public as a result of postponing decommissioning must be considered. A health-risk model is used that ranks each project relative to all other surplus facilities maintenance program (SFMP) projects based on the condition of the facility, the amount and types of radioactive material present in the facility, and the population and meteorological conditions of the area surrounding the facility.

4. Future Site Plans--The compatibility of the existing facility with future plans for the site is a factor used to identify facilities that are incompatible with either existing or projected future uses of the site on adjoining sites.

5. Cost-Effectiveness Program Management--Cost-effective program management is another evaluation factor that could result in early initiation of a decommissioning project or delay it until a later date. This factor concerns the availability of a developed, efficient organization for the facility project. Where organized programs are already in place at a site, D\&D work for facilities on the site will proceed more efficiently and safely than for projects where staff development and training rampup are still required. Cost-effective program management may have important influence on the total cost of this project. High weight is assigned to cost; thus, this factor may have significant bearing on project prioritization.

6. Other Special Factors--In some instances, special factors may be unique to a few projects and might contribute to the overall priority ranking of these projects. Special factors such as local government concerns and public opposition or acceptance of proposed D\&D work may influence a project priority.

\subsubsection{Prioritization of Projects}

The criteria presented above were considered in establishing the order in which the facilities are decommissioned. The listing of facilities scheduled for decommissioning presented in Appendix $C$ are in order of priority; however, it should be recognized that changes in the ranking may be necessary to accommodate unforeseen change in the availability of funds, regulatory requirements, and changes to the above factors. 


\subsection{WORK ELEMENTS}

\subsection{GENERAL}

The work elenents fall in three general categories: (1) program management and administration, (2) surveillance and maintenance, and (3) decommissioning projects. The specific work elements and cost for these categories are identified in Appendix $C$.

\subsubsection{Program Management and Administration}

The program management and administration activity includes the HSFP manager, his staff, and various support services. This activity provides the long-range planning, advanced engineering, and program management.

\subsubsection{Surveillance and Maintenance}

The surveillance and maintenance activity includes the staff dedicated to this activity and the support services received from 100 Area, Site Surveillance Health Physics, and Operations Support Services. Cost for surveillance and maintenance will vary with the level of maintenance required to maintain the confinement of radioactive materials and provide the degree of safety required to comply with the goals and objectives of Westinghouse Hanford and the DOE-RL. For planning purposes, the surveillance and maintenance cost is estimated at $\$ 5$ million annually.

\subsubsection{Decommissioning Projects}

A project comprises work elements that may include several individual facilities. The tables in Appendix A identify the facilities in each project and assign task numbers to the project. The budget requirement for disposing of the current inventory of retired facilities is estimated at approximately $\$ 800$ million.

\subsubsection{Underground Storage Tanks}

The reinoval of underground tanks regulated by 40 CFR Parts 280 and 281 is being coordinated through the Surplus Facilities Program office. The implementation plan for this work is included in the work packages.

\subsubsection{Asbestos Abatement}

The asbestos abatement program is being consolidated by the representatives of HSFP office into a site-wide program. The consolidated program plan will be documented under separate cover, and will outline a management plan to be followed in implementing asbestos abatement. 


\section{WHC-EP-0231-3}

\subsubsection{Reactor Support Facilities}

There are 18 noncontaminated facilities in the 100 and 200 Areas that supported the production facilities. These have been added to the schedule for decommissioning and are 1 isted under A-12 in Appendix $A$. 
WHC -EP-0231-3

\subsection{CONTROL}

\subsection{INDUSTRIAL AND RADIOLOGICAL SAFETY}

In line with Westinghouse Hanford policy to operate and maintain companymanaged facilities according to DOE Orders and in compliance with the letter and spirit of other applicable federal, state, and local regulations, Table 1 has been prepared and shows the orders critical to control the items listed below.

\subsubsection{Industrial Safety}

Transfer of new facilities to the status of "retired" is accepted on completion of a Facilities Transfer form. Before a facility is accepted, it is inspected and any deviation from conditions noted are resolved. Ince the facility has been accepted, it is placed on the surveillance and maintenance schedule to receive inspections, surveys, and maintenance as required to meet the goals and objectives of the ongoing safety program of Westinghouse Hanford.

The safety of a facility is the single most important factor in funding to eliminate the hazards or scheduling a facility for decommissioning. When a facility is targeted for decommissioning, a detailed engineering package is developed that includes a safety hazards analys is and a startup readiness review. Before starting work, the startup readiness review is made, evaluating the safety preparedness of the workers, adequacy of procedures to cope with potential hazards, and the safety conditions of the facility and site. The readiness review also ensures that all environmental and safety documentation is in place. During the progress of work, regular safety meetings and safety inspections are made. The personnel assigned to the project participate in all ongoing safety programs. At the completion of the project, a project closeout report is issued. This report identifies the status of the site at the end of the project and identifies surveillance and maintenance requirements, if needed beyond the closeout.

\subsubsection{Radiological Safety}

Monitoring for radiological and environmental safety will be in compliance with established controls.

Waste disposal will be made in compliance with DOE order 5480.1A (DOE-RL 1988). The ARCL methodology developed by Pacific Northwest Laboratory (PNL) will be used, as applicable, to define the amount of radioactive material that may safely remain after decommissioning a facility. The management of various types of waste generated during D\&D is outlined in the following sections. 
Table 1: Regulatory Requirements. (sheet 1 of 3 )

\begin{tabular}{|c|c|c|}
\hline $\begin{array}{l}\text { DOE Order } \\
\text { Number }\end{array}$ & Title & Comments \\
\hline 1324.2 & Records Disposition & $\begin{array}{l}\text { Establishes records handling } \\
\text { procedures }\end{array}$ \\
\hline 3790.1 & $\begin{array}{l}\text { Occupational Safety } \\
\text { and Health Program } \\
\text { for Federal Employees }\end{array}$ & $\begin{array}{l}\text { Establishes the policy for } \\
\text { implementing and administration } \\
\text { of occupational safety and health } \\
\text { program. }\end{array}$ \\
\hline $\begin{array}{l}4300.1 B \\
4320.1 A\end{array}$ & $\begin{array}{l}\text { Real Property and } \\
\text { Site Development } \\
\text { Site Development and } \\
\text { Facility Utilization }\end{array}$ & $\begin{array}{l}\text { Provides requirements for } \\
\text { preparing site development } p l \text { ans } \\
\text { and facility utilization for DOE } \\
\text { facilities. }\end{array}$ \\
\hline 5000.3 & $\begin{array}{l}\text { Unusual Occurrence } \\
\text { Reporting System }\end{array}$ & $\begin{array}{l}\text { Establishes DOE policy and } \\
\text { provides instructions for } \\
\text { reporting, analyzing, and } \\
\text { disseminating information on } \\
\text { programmatically significant } \\
\text { events. }\end{array}$ \\
\hline 5100.3 & Field Budget Process & $\begin{array}{l}\text { Establishes budget procedure and } \\
\text { requirements. }\end{array}$ \\
\hline 5400.1 & $\begin{array}{l}\text { General Environmental } \\
\text { Protection Program } \\
\text { Requirements }\end{array}$ & $\begin{array}{l}\text { The order defines environmental } \\
\text { protection requirements that are } \\
\text { established in DOE Order } 5400.1 \mathrm{~B} \text {. } \\
\text { A11 CM, MP, and MRP references in } \\
\text { the DOE Orders } 5400 \text { series have } \\
\text { application to this order. }\end{array}$ \\
\hline $\begin{array}{l}5400 . x y \\
\text { In Draft }\end{array}$ & $\begin{array}{l}\text { Radiological Effluent } \\
\text { Monitoring and } \\
\text { Environmental } \\
\text { Surveillance }\end{array}$ & $\begin{array}{l}\text { Provides guidance for } \\
\text { radiological monitoring and } \\
\text { environmental surveillance. }\end{array}$ \\
\hline 5400.3 & $\begin{array}{l}\text { Hazardous and } \\
\text { Radioactive Mixed } \\
\text { Waste Management }\end{array}$ & $\begin{array}{l}\text { Provides instructions for } \\
\text { implementing a DOE hazardous } \\
\text { waste management program. }\end{array}$ \\
\hline 5400.4 & $\begin{array}{l}\text { Comprehensive } \\
\text { Environmental } \\
\text { Response, } \\
\text { Compensation, and } \\
\text { Liability Act } \\
\text { Requirements }\end{array}$ & $\begin{array}{l}\text { Provides direction for } \\
\text { implementing a DOE CERCLA } \\
\text { program. }\end{array}$ \\
\hline
\end{tabular}


Table 1. Regulatory Requirements. (sheet 2 of 3 )

\begin{tabular}{|c|c|c|}
\hline $\begin{array}{c}\text { DOE Order } \\
\text { Number }\end{array}$ & Title & Comments \\
\hline 5400.5 & $\begin{array}{l}\text { Radiation Protection of the } \\
\text { Public and the Environment }\end{array}$ & $\begin{array}{l}\text { Presents a progran and standards } \\
\text { for radiation protection. }\end{array}$ \\
\hline $5440.1 B$ & $\begin{array}{l}\text { National Environmental } \\
\text { Policy Act (NEPA) }\end{array}$ & $\begin{array}{l}\text { Establishes DOE policy for } \\
\text { implementation of NEPA } 1969 .\end{array}$ \\
\hline $5480.1 \mathrm{~A}$ & $\begin{array}{l}\text { Environmental Safety and } \\
\text { Health Program for DOE } \\
\text { Operations }\end{array}$ & $\begin{array}{l}\text { Outlines environmental } \\
\text { protection, safety and health } \\
\text { protection policies and } \\
\text { responsibilities. }\end{array}$ \\
\hline 5400.5 & $\begin{array}{l}\text { Radiation Protection of the } \\
\text { Public and the Environment }\end{array}$ & $\begin{array}{l}\text { Presents a program and standards } \\
\text { for radiation protection. }\end{array}$ \\
\hline $5482.1 \mathrm{~B}$ & $\begin{array}{l}\text { Environmental, Safety, and } \\
\text { Health Appraisal Program }\end{array}$ & $\begin{array}{l}\text { Establishes DOE environmental } \\
\text { protection, safety, and health } \\
\text { protection appraisal program. }\end{array}$ \\
\hline 5484.1 & $\begin{array}{l}\text { Environmental Protection, } \\
\text { Safety, and Health } \\
\text { Protection Information } \\
\text { Reporting Requirements }\end{array}$ & $\begin{array}{l}\text { Specifies requirements and } \\
\text { procedures for reporting and } \\
\text { investigating matters of } \\
\text { environmental protection, } \\
\text { safety, and health protection } \\
\text { significant to DOE operations. }\end{array}$ \\
\hline 5700.4 & Project Management System & $\begin{array}{l}\text { Establishes requirements and } \\
\text { objectives, and assigns } \\
\text { responsibilities and authorities } \\
\text { necessary for acquisition of } \\
\text { major systems. }\end{array}$ \\
\hline $5780.6 \mathrm{~B}$ & Quality Assurance & $\begin{array}{l}\text { Defines DOE's Quality Assurance } \\
\text { program. }\end{array}$ \\
\hline 5720.2 & $\begin{array}{l}\text { Radioactive Waste } \\
\text { Mariegement }\end{array}$ & $\begin{array}{l}\text { Policies and guidelines for } \\
\text { management of radioactive waste } \\
\text { and contaminated facilities. }\end{array}$ \\
\hline 6530.1 & $\begin{array}{l}\text { General Design Criteria } \\
\text { Manual }\end{array}$ & $\begin{array}{l}\text { Provides general design criteria } \\
\text { for use in requisitions of DOE } \\
\text { facilities. }\end{array}$ \\
\hline
\end{tabular}


Table 1. Regulatory Requirements. (sheet 3 of 3 )

\begin{tabular}{|c|l|l|}
\hline $\begin{array}{c}\text { Washington } \\
\text { State } \\
\text { Control }\end{array}$ & \multicolumn{1}{|c|}{ Title } & \multicolumn{1}{|c|}{ Comments } \\
\hline WAC 173-303 & $\begin{array}{l}\text { Dangerous Waste } \\
\text { Regulations }\end{array}$ & $\begin{array}{l}\text { Identifies dangerous solid } \\
\text { wastes, defines surveillance and } \\
\text { monitoring requirements, } \\
\text { reporting and tracking } \\
\text { requirements, regulations for } \\
\text { siting, construction, operation } \\
\text { and disposal of facilities, } \\
\text { permit requirements, and } \\
\text { encourages recycling. }\end{array}$ \\
\hline 5481.1 & $\begin{array}{l}\text { Safety Analysis and } \\
\text { Review System }\end{array}$ & $\begin{array}{l}\text { Provides a system for evaluating } \\
\text { safety preparedness and approval } \\
\text { to implement and proceed with } \\
\text { work. }\end{array}$ \\
\hline
\end{tabular}

NOTE: Westinghouse Hanford Company addresses the U.S. Department of Energy regulations in various manuals, procedures, and data compilations.

Table 2. Release Levels and Priorities for Decommissioned Facilities and Land Areas.

\begin{tabular}{|c|l|l|}
\hline Priority & \multicolumn{1}{|c|}{ Release level } & \multicolumn{1}{c|}{ Site status } \\
\hline 1 & $\begin{array}{l}\text { Decontaminate to less than } \\
\text { detectable }\end{array}$ & $\begin{array}{l}\text { Site can be released immediately } \\
\text { for unrestricted use. }\end{array}$ \\
\hline 2 & $\begin{array}{l}\text { ARCL of } 25 \text { mrem/year or less } \\
\text { immediately following } \\
\text { decommissioning. }\end{array}$ & $\begin{array}{l}\text { Site can be released immediately } \\
\text { for unrestricted use. }\end{array}$ \\
\hline 3 & $\begin{array}{l}\text { ARCL of } 25 \mathrm{mrem} / \text { year or less } \\
\text { within 100-year } \\
\text { institutional control } \\
\text { period. }\end{array}$ & $\begin{array}{l}\text { Site can be released in the year } \\
\text { that the radionuclides have } \\
\text { decayed to ARCL value of less } \\
\text { than } 25 \mathrm{mrem} / \text { year. }\end{array}$ \\
\hline 4 & $\begin{array}{l}\text { ARCL of up to 500 mrem/year } \\
\text { at end of 100-year } \\
\text { institutional control } \\
\text { period. }\end{array}$ & $\begin{array}{l}\text { DOE-RL approval is needed to } \\
\text { exceed } 25 \mathrm{mrem} / \text { year. }\end{array}$ \\
\hline
\end{tabular}

${ }^{a}$ Allowable residual contamination levels.

b.S. Department of Energy-Richland Operations Office. 
WHC -EP-0231-3

\subsubsection{Management of Waste Generated during Decontamination and Decommissioning.}

6.1.2.1.1 Clean Waste--Clean wastes that are free of radioactive contamination and other hazardous material such as wood, cloth, paper, plastic, and most construction materials are not subject to regulation and will be disposed of in approved clean waste landfills.

6.1.2.1.2 Mixed Waste--Waste that is both a radioactive hazard and a chemical hazard is designated mixed waste. Mixed waste will be packaged and disposed of in accordance with provisions of Part 1 of WHC-CM-7-5

Environmental Compliance and WAC 173-303 as implemented in WHC-CM-5-16 (WHC 1989).

6.1.2.1.3 High-Level Radioactive Waste--Readily retrievable high-level waste will be processed to a final immobilized form in the Defense Waste Processing Facility and the Waste Vitrification Plant preparatory to permanent disposal in a deep geologicdl repository (WHC-CM-7-5, DOE 5820.2A, 1988).

6.1.2.1.4 Transuranic Waste--Transuranic waste will be transferred in compliance with DOE and Department of Transportation (DOT) regulations to the Waste Isolation Plant for interim storage and safe disposal (WHC-CM-7-5, DOE 5820.2A).

6.1.2.1.5 Low-Level Radioactive Waste--Low-level waste will be processed by two general disposal methods. When the low-level waste meets the requirements of $A R C L$ calculations, the waste will be disposed of in situ. If a low-levei waste fails to meet $A R C L$ requirements, the waste will be packaged and shipped to the approved low-level waste burial ground in the 200 Area (WHC-CM-7-5, DOE 5820.2A).

\subsection{Hazardous Waste--The Washington State Dangerous Waste} Regulations, Washington Administrative Code (WAC 1989) will be used to classify the type of hazardous waste. The regulations in WAC 173-303 will be implemented by the applicable procedures in Westinghouse Hanford Controlled Manuals 4-2, 2-14,1-1, 1-3, and 7-5 (WHC 1989, 1990).

6.1.2.2 Waste Left at the Site (Decommissioned In Situ). The majority of radioactive wastes will be left in place as the facilities are decommissioned. The amount (curies) that can remain safely in a decommissioned facility is the amount that will not produce an annual whole body dose or organ dose greater than 25 mrem to an individual living on the site released. The ARCL methodology is used to estimate dose from the residual radioactivity by analysis. This methodology is explained in the following section.

6.1.2.3 Allowable Residual Contamination Levels. The historic practice at the Hanford Site is to release equipment and materials for unrestricted use when found to be "free of contamination." Generally, the definition for free 
of contamination has been less than detectable with portable radiation detection instrumentation, such as a Geiger Muller or portable alpha monitor. This same approach has been used for decontamination and decommissioning of surplus facilities, i.e., cleanup to less-than-detectable levels before release and demolition.

The DCE recently adopted the release limits defined in Regulatory Guide 1.86 (NRC 1974). These limits, in some cases, are less restrictive than the less-than-detectable criterion. In the spirit of the ALARA philosophy, the less-than-detectable criterion will be used whenever practicable. However, in all cases, material released for offsite use will, as a minimum, meet the limits defined in Regulatory Guide 1.86. Use of Regulatory Guide 1.86 release limits requires the previous approval of Westinghouse Hanford Environmental and Occupational Safety.

This conservative approach is corisidered a good practice when releasing equipment and materials for offsite use; however, when the less-thandetectable criterion is applied to clean up surplus facilities, it can result in unreasonably high cost. Therefore, the DOE-RL has directed the Hanford Site contractors to use the ARCL methodology, where applicable, to establish radiological release criteria for decommissioning surplus contaminated facilities on the Hanford Site.

The ARCL method, developed by PNL, defines the amount of radioactive material that may remain safely after a facility has been decommissioned. The ARCL method defines realistic exposure scenarios, based on an analysis of potential radiation exposure pathways. The scenarios consider the numerous ways in which persons could be exposed to the remaining radioactive materials during or after institutional control of the site.

The radiological inventory of the facility is estimated from sampling data and then, using the appropriate dose pathways, a dose along with a $90 \%$ upper-confidence limit is estimated. If the predicted potential dose to an individual determined by this method is less than $25 \mathrm{mrem} /$ year, then no further actions would be required for that site. If the predicted potential dose exceeds the limit, then additional remedial action must be taken.

\subsubsection{Application of the Allowable Residual Contamination Limits Method.} Current DOE guidance requires that the dose to a maximally exposed person, following the release of a decommissioned facility or land area for unrestricted use, be less than $25 \mathrm{mrem} /$ year to the whole body or any organ. (A maximally exposed site resident is assumed to receive the maximum possible radiation dose fiom all of the exposure pathways on a particular site.)

If the ARCL analysis indicates that the $25 \mathrm{mrem} /$ year criterion cannot be achieved cost effectively for a particular site, then the DOE-RL must approve the specific dose ievels for that site, calculated by use of the ARCL method, 
before initiation of the decommissioning work. The ALARA philosophy is applicable whenever it is cost effective to reduce doses below the $25 \mathrm{mrem} /$ year level.

Table 2 lists dose levels to a maximally exposed person and how dose levels relate to site status after decominissioning. The ALARA philosophy and cost-effectiveness are of primary importance in determining which release level will be achieved for a particular site.

6.1.2.5 Release of Materials for Unrestricted Offsite Use. The DOE recently a'dopted the release limits defined in Regulatory Guide 1.86 (NRC 1974). These limits, in some cases, are less restrictive than the less-than-detectable criterion. In the spirit of the ALARA philosophy, the less-than-detectable criterion will be used whenever practicable. However, in all cases, material released for offsite use will, as a minimum, meet the limits defined in Regulatory Guide 1.86. Use of Regulatory Guide 1.86 release limits requires the previous approval of Westinghouse Hanford Environmental and Occupational Safety. Table 3 lists these criteria.

6.1.2.6 Disposition of Contaminated Equipment. Equipment contaminated with radioactive materials should be dispositioned using the priorities listed below. The intent of these priorities is to practice the ALARA philosophy by minimizing the movement and handling of radioactive materials.

- Reuse Equipment--Equipment should be removed for reuse if it is cost effective to do so and if a new user for the equipment has been identified. The new user will provide the funds for removal and transport to the new location.

- Leave Equipment in Place--If a cost-effective reuse is not identified, equipment should be left in place. This priority should be used only if the radioactive material on the equipment can be contained during the demolition phase of decommissioning.

- Relocate Equipment in Same Facility--If there is a potential for release of radioactive material to the environment during demolition of the facility containing the equipment, the equipment should be relocated to an area in the same facility where it is protected (e.g., tunnel, basement) before demolition.

- Relocate Equipment to Another Contaminated Facility--If equipment cannot be left in place or relocated in its own facility, the equipmeni should be relocated to a below-grade void in another contaminated facility where it can be covered with a minimum of $1 \mathrm{~m}$ of clean fill. 
Table 3. Acceptable Surface Contamination Levels for Materials Removed from the Site.

\begin{tabular}{|c|c|c|c|}
\hline Radionuclide & Average $^{b, c}$ & Maximum ${ }^{b, d}$ & Removable $e^{b, e}$ \\
\hline $\begin{array}{l}\text { Uranium (natural), } \\
{ }^{235} \mathrm{U},{ }_{238} \mathrm{U} \text { associated } \\
\text { decay products }\end{array}$ & $\begin{array}{l}5,000 \mathrm{dpm} \\
\text { aipha } / 100 \mathrm{~cm}^{2}\end{array}$ & $\begin{array}{l}15,000 \mathrm{dpm} \\
\text { a)pha } / \mathrm{cm}^{2}\end{array}$ & $\begin{array}{l}1,000 \mathrm{dpm} \\
\text { alpha } / \mathrm{cm}^{2}\end{array}$ \\
\hline $\begin{array}{l}\text { Transuranics, }{ }^{226} \mathrm{Ra}, \\
{ }^{228} \mathrm{Ra},{ }^{230} \mathrm{Th},{ }^{228} \mathrm{Th}, \\
{ }^{231} \mathrm{~Pa},{ }^{227} \mathrm{Ac},{ }^{125} \mathrm{I}, \\
{ }^{129} \mathrm{I}\end{array}$ & $100 \mathrm{dpm} / 100 \mathrm{~cm}^{2}$ & $300 \mathrm{dpm} / 100 \mathrm{~cm}^{2}$ & $20 \mathrm{dpm} / 100 \mathrm{~cm}^{2}$ \\
\hline $\begin{array}{l}\text { Thorium (natural) } \\
{ }^{232} \mathrm{rh},{ }^{90} \mathrm{Sr},{ }^{223} \mathrm{Ra}, \\
{ }^{224} \mathrm{Ra},{ }^{232} \mathrm{U},{ }^{126} \mathrm{I}, \\
{ }^{131} \mathrm{I},{ }^{133} \mathrm{I}\end{array}$ & $1,000 \mathrm{dpm} / 100 \mathrm{~cm}^{2}$ & $3,000 \mathrm{dpm} / 100 \mathrm{~cm}^{2}$ & $200 \mathrm{dpm} / 100 \mathrm{cll}^{2}$ \\
\hline $\begin{array}{l}\text { Beta-gamma emitters } \\
\text { (radionuclides with } \\
\text { decay modes other } \\
\text { than alpha emission } \\
\text { or spontaneous } \\
\text { fission, except } \\
{ }^{90} \text { Sr and others } \\
\text { noted above) }\end{array}$ & $\begin{array}{l}5,000 \mathrm{dpm} / B-Y / \\
100 \mathrm{~cm}^{2}\end{array}$ & $\begin{array}{l}15,000 \mathrm{dpm} / \mathrm{B}-\mathrm{Y} / \\
100 \mathrm{~cm}^{2}\end{array}$ & $\begin{array}{l}1,000 \mathrm{dpm} / B-Y / \\
100 \mathrm{~cm}^{2}\end{array}$ \\
\hline
\end{tabular}

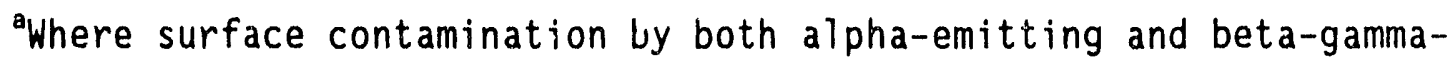
emitting nuclides exists, the limits established for alpha-emitting and beta-gamma emitting nuclides should apply independently.

${ }^{5}$ As used in this table, dpm (disintegrations per minute) means the rate of emission by radioactive materials as determined by correcting the counts per minute observed by an appropriate detector for background, efficiency, and geometric factors associated with the instrumentation.

'Measurements of average contaminant should not be averaged over more than $1 \mathrm{~m}^{2}$. For objects of less surface area, the average should be derived for each such object. $100 \mathrm{~cm}^{2}$.

The maximum contamination level appiies to an area of not more than

'The amount of removable radioactive material per $100-\mathrm{cm}^{2}$ surface area should be determined by wiping that area with dry filter or soft, absorbent paper, applying moderate pressure, and assessing the amount of radioactive material on the wipe with an appropriate instrument of known efficiency. When removable contamination on objects of less surface is determined, the pertinent levels should be reduced proportionally, and the entire surface should be wiped. 
- Relocate Equipment to a Noncontaminated Facility--If the equipment cannot be relocated to a void in another contaminated facility, it should be relocated to a void in a noncontaminated facility that is scheduled to be decommissioned. Special authorization from Westinghouse Hanford Environmental and Occupational Safety is required for this option.

- Remove Equipment for Burial--As a last resort, the equipment should be removed and packaged for disposal at the Hanford Site 200 Area low-level waste disposal site.

\subsection{DISPOSITION OF NONRADIOACTIVE, HAZARDOUS MATERIAL}

The disposition of nonradioactive, hazardous wastes and materials, including asbestos, mercury, polychlorinated biphenyl (PCB) 0i1, and possible other materials, will be addressed in the safety hazards assessment issued by Westinghouse Hanford, in accordance with DOE directives, before any actual decommissioning work begins on a facility. The applicable decommissioning work procedures will provide explicit instructions to control the release of any hazardous material during decommissioning work. Table 4 lists some of the significant nonradioactive hazardous materia?s present in the Hanford Site facilities. In addition, Section 6.1.2.1 outlines the management of various types of waste generated during the D\&D process.

\subsection{QUALITY ASSURANCE}

A quality assurance (QA) plan has been prepared for implementation of Nuclear Quality Assurance-1 requirements for D\&D activities. The QA plan applies to operations performed on surplus facilities, inactive sites, and selected treatment, storage, and disposal facilities subject to closure requirements at the Hanford Site.

\subsection{PROJECT MANAGEMENT AND CONTROL}

The administrative controls for tracking cost and schedules are listed in the following.

\subsubsection{Cost and Schedule Performance Monitoring}

The HSFP will track cost and schedule, using Westinghouse Hanford Management Control System. 
Table 4. Nonradioactive, Hazardous Materials Present in the Hanford Site Shutdown Facilities."

\begin{tabular}{|l|l|l|}
\hline \multicolumn{1}{|c|}{ Material } & \multicolumn{1}{|c|}{ Location } & \multicolumn{1}{c|}{ Preferred disposition } \\
\hline Asbestos & $\begin{array}{l}\text { Pipe insulation in many } \\
\text { facilities; siding } \\
\text { material and floor } \\
\text { covering on a number of } \\
\text { facilities }\end{array}$ & $\begin{array}{l}\text { All friable asbestos will be } \\
\text { removed and disposed of in } \\
\text { accordance with established } \\
\text { procedures. }\end{array}$ \\
\hline Mercury & $\begin{array}{l}\text { Panel gauges for } \\
\text { control equipnient in } \\
\text { all facilities. }\end{array}$ & $\begin{array}{l}\text { All mercury will be removed } \\
\text { before decommissioning. }\end{array}$ \\
\hline $\begin{array}{l}\text { Polychlorinated } \\
\text { biphenyl (PCB) } \\
\text { oil shutdown }\end{array}$ & $\begin{array}{l}\text { In transformers. } \\
\text { fall PCB remaining in }\end{array}$ \\
\hline Lead & $\begin{array}{l}\text { Reactors, shielding } \\
\text { joints, and storage } \\
\text { jofities will be removed } \\
\text { Sampling program currently } \\
\text { is being conducted to } \\
\text { determine PCB inventories. }\end{array}$ \\
\hline
\end{tabular}

aisting is not all inclusive. Some chemical hazardous wastes have not been included.

This earned-value system tracks cost, schedule, and performance on a monthly and to-date basis of all decommissioning projects as they progress toward completion. Cost-performance reports will be prepared through the FDS on a monthly basis. The reports will use the CAPs to establish a fiscal year performance baseline. The report will compare scheduled cost, budget cost of work scheduled (BCWS), to work performance, budget cost of work performed $(B C W P)$, to actual cost of work performed (ACWP). Any deviations from the planned schedules or spending will be reported as a schedule variance (SV) or a cost variance (CV). If the variances exceed the thresholds of $10 \%$ or $\$ 100,000$, whichever is less, the CAM is required to complete a variance analysis report (VAR), which is to be returned to the activity manager by the tenth working day of the following month. The VAR will explain cause for the SVs and CVs, along with corrective action and impacts. Additionally, a current fiscal year and future year's estimate at completion (EAC), along with a total estimate cost (TEC), will be calculated. The VAR information will be reviewed by the activity manager and approved by the HSFP manager. 
Changes to the work scheduled in the base plan will be documented by processing a change control request. An approved copy of the change request will be filed by Program Administration in the Program Office.

\subsection{REGULATORY REQUIREMENTS}

The DOE regulatory requirements are implemented through the various control manuais developed by Westinghouse Hanford as management directives (see Table 1). These directives, as applicable to the HSFP, become a part of the activities associated with surveillance, maintenance, and decommissioning of the facilities. The requirements are to provide employees with clear, documented guidelines consisting of policies, work procedures, performance requirements, process or equipment operational limits, and the following rules of conduct.

- Avoid or mitigate nuclear, radiological, environmental, or industrial safety incidents.

- Protect the general public and employees from injury.

- Avoid or mitigate production or property losses.

- Ensure compliance with DOE Orders, state and federal laws and regulations, industrial codes and standards, requirements of prime contract with the DOE, and Westinghouse Corporate policies.

- Ensure the financial integrity and cost effectiveness of operations of Westinghouse Hanford.

- Ensure the quality and technical excellence of work performed.

\subsection{FACILITY ACCEPTANCE AND TRANSFER}

\subsubsection{Facility Transfer and Acceptance Requirements}

To be eligible for acceptance in the HSFP, facilities must meet the following administrative, technical, and physical requirements.

- The facility and surrounding area will be in a radiologically safe ondition, with a current radiation and hazardous chemical survey complete and available.

- The struc ure(s) and monitoring system will be in a condition adequate to contain and monitor for radiation, contamination, and hazardous chemicals. 
- All stored special nuclear materials, reactor fuels, radioactive contaminated liquids, and hazardous chemicals will have been removed from the facility. In addition, all bulk and containerized radioactive-contaminated waste and sludge will have been removed from the facility.

- Deactivation and shutdown status of the facility will have been documented (i.e., final radiological and hazardous substance survey, final configuration, surveillance and maintenance records, and requirements).

- If available, a formal surveillance and maintenance plan will be provided.

- Security systems and procedures will be adequate to prevent unauthorized entry.

\subsubsection{Facility Transfer into the Program}

The required actions to transfer a surplus facility into the HSFP are coordinated between the manager of HSFP and the building manager.

If a facility is accepted, HSFP management incorporates it into the program $\mathrm{plans}$ and budget until disposition is complete and the facility is transferred out of the program. Identification of the funding source for surveillance, maintenance, and decommissioning will be determined at the time the facility is being considered for transfer, and the agreement then becomes part of the approval documentation.

\subsubsection{Facility Transfer out of tile Program}

When determined there is a use for a facility currently in the HSFP or the decommissioning of a facility is completed, a formal letter is submitted to HSFP requesting its transfer out of the program. Organizations accepting the facility from the HSFP assume full responsibility for the facility and any further disposition, including decommissioning as appropriate. 


\subsubsection{Identification and Description of Surplus Facilities Questionnaire}

A facility questionnaire form (which includes information that will assist users when filling out the form) and a suggested form letter for submitting a facility transfer request to HSFP is documented in special Program Management Instructions. The forms are in four parts and identified as follows:

Part 1. Facility Disposition Planning and Cost Data (Form No. A3000-423)

Part 2. Facility Data

(Form No. A3000-424)

Part 3. Facility Radiological Data

(Form No. A3000-426)

Part 4. Surveillance Data

(Form No. A3000-425)

\subsubsection{Property Management}

Before the disposition of a facility and piece of equipment, a declaration of excess is prepared which makes the property available to other organizations and government agencies. If no interest is shown, a property disposal request form is completed and the facility and equipment are disposed of. Disposal can include demolition or salvage. Regardless of the final disposition, the facility and equipment must be properly released. Release criteria are outlined in Section 6.1. 
WHC-EP-0231-3

\subsection{DOCUMENTATION AND APPROVALS}

\subsection{SURVEILLANCE AND MAINTENANCE GUIDELINES}

Surveillance and maintenance guidelines unify the surveillance and maintenance activities concerning responsibility, surveillance inspection, maintenance, monitoring, and recordkeeping. These guidelines set forth the surveillance and maintenance requirements that will be used in documenting unit procedures and tasks performed in surveillance and maintenance as outlined in site-specific instructions. These guidelines require approval of the HRO manager.

The surplus facilities will be maintained to meet the requirements of protective storage until an alternative is opted and funded for final disposition. Long-range surveillance and maintenance plans for the 100 Areas and 200 Areas are being revised and will be reissued in FY 1991.

\subsection{DECOMMISSIONING PROJECT WORK}

All surplus facilities will be segregated into work packages. When the decision is made to decommission a facility and funding is available, a project proposal will be developed tha $i$ includes detailed engineering, detailed procedures on how the job is to be done, safety hazard analysis, a start-up readiness review, and project closeout requirements. These elements of the project are documented in the project $\mathrm{plan}$ and require various levels of approval depending on the size of the project. Approval levels are set forth under the Westinghouse Hanford management control system. Work approval for the specific tasks is established in the work package project plan.

\subsection{LISTINGS OF HANFORD SITE FACILITIES}

A listing of all aboveground facilities, both operational and retired, is maintained by Westinghouse Hanford Support Services, Facility Management and Site Planning. A listing of all underground facilities (i.e., cribs, tanks, and burial grounds) is maintained by Westinghouse Hanford Environmental Division, Environmental Engineering. 
WHC-EP-0231-3

\subsection{REFERENCES}

DOE, 1988, Radioactive Waste Management, DOE Order 5820.2A, U.S. Department of Energy, Washington, D.C.

DOE-RL, 1982, Surplus Facilities Management Program Methodology for Establishing Decommissioning Priorities, RLO/SFM-82-7, U.S. Department of Energy-Richland Operations Office, Richland, Washington.

DOE-RL, 1983, Safety Analysis Review System, DOE-RL Order 5481.1, U.S. Department of Energy-Richland Operations Office, Richland, Washington.

DOE-RL, 1988, Environment, Safety, and Health Program for Department of Energy Operations for Richland Operations, DOE-RL Order 5480.1A, U.S. Department of Energy-Richland Operations Office, Richland, Washington.

Ecology, 1989, Dangerous Waste Regulations, Washington Administrative Code, WAC 173-303, Washington State Department of Ecology, 0lympia, Washington.

NRC, 1974, Termination of Nuclear Operating Licenses for Nuclear Reactors, Regulatory Guide 1.86, U.S. Nuclear Regulatory Commission, Washington, D.C.

WHC, 1989a, Environmental Compliance Manual, WHC-CM-7-5, Westinghouse Hanford Company, Richland, Washington.

WHC, 1989b, Hazardous Material Packaging and Shipping, WHC-CM-2-14, Westinghouse Hanford Compaliy, Richland, Washington.

WHC, 1989c, Nonradioactive Dangerous Waste Disposal Manual, WHC-CM-5-16, Westinghouse Hanford Company, Richland, Washington.

WHC, 1990a, Management Policies, WHC-CM-1-1, Rel. 24, Westinghouse Hanford Company, Richland, Washington.

WHC, 1990b, Management Requirements and Procedures, WHC-CM-1-3, Re1. 46, Westinghouse Hanford Company, Richland, Washington.

WHC, 1990c, Quality Assurance Manual, WHC-CM-4-2, Releases 22-28, 30, Westinghouse Hanford Company, Richland, Washington. 
WHC-EP-0231-3

APPENDIX A

WORK ELEMENTS

$\bar{A}-1 / \hat{\alpha}$ 
WHC-EP-0231-3

\section{APPENDIX A}

\section{A.1 WORK ELEMENTS}

Following is a list of facilities within the Hanford Surplus Facilities Programs (HSFP) that currently are being maintained and controlled in accordance with specific surveillance and maintenance procedures while awaiting decontamination and decommissioning (D\&D).

Accompanying each facility identification title and/or number is a brief description, including type of construction, overall dimensions, estimated decommissioning cost, current plan for fiscal year project work to commence, and related work breakdown structure (WBS) numbers. All project costs are estimates and are in constant fiscal year (FY) 1991 dollars. 
A.2 100 AREA REACTORS. (sheet 1 of 3 )

\begin{tabular}{|c|c|c|c|c|c|c|}
\hline 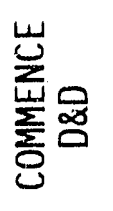 & $\begin{array}{l}\text { शे } \\
\text { す̆ } \\
\text { 乙 }\end{array}$ & $\begin{array}{l}\overline{0} \\
\text { N } \\
\text { Lे }\end{array}$ & $\begin{array}{l}\text { 合 } \\
\text { 芒 }\end{array}$ & $\begin{array}{l}\text { ¿े } \\
\stackrel{N}{L} \\
\text { ¿े }\end{array}$ & $\begin{array}{l}\text { 옹 } \\
\text { ż }\end{array}$ & 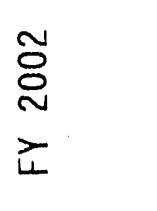 \\
\hline 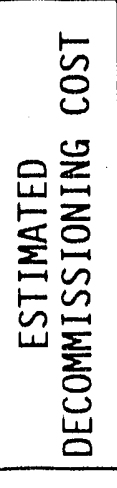 & 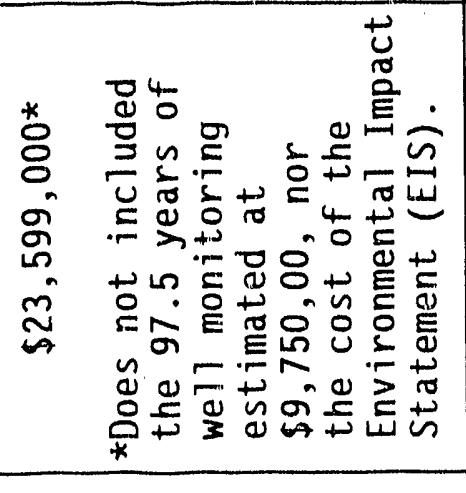 & 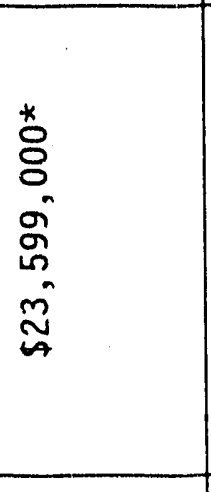 & 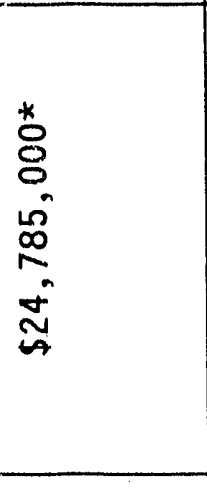 & 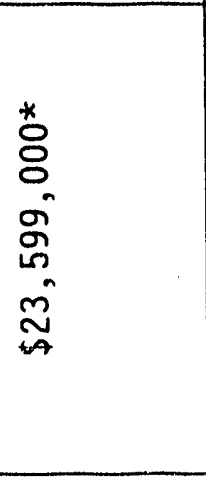 & 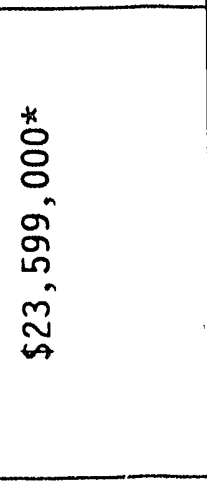 & 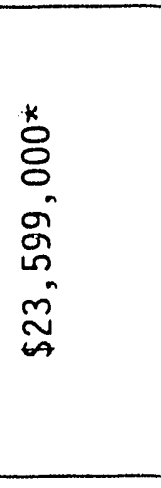 \\
\hline 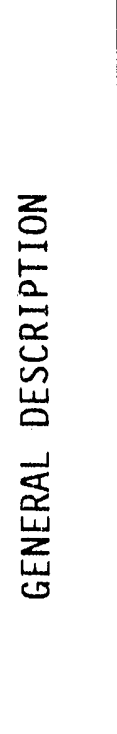 & 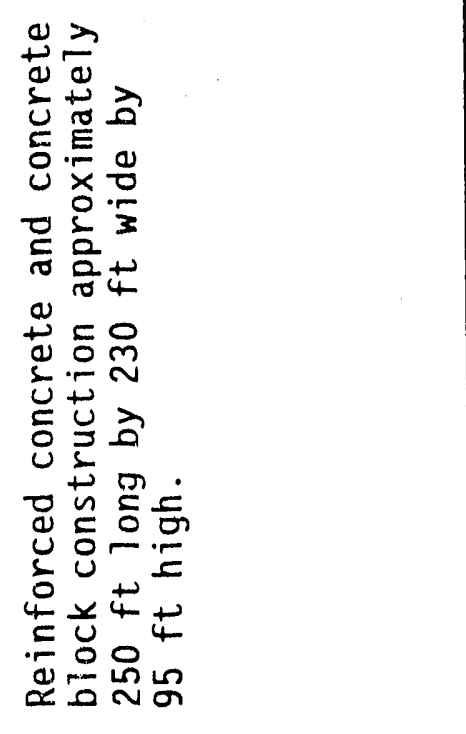 & 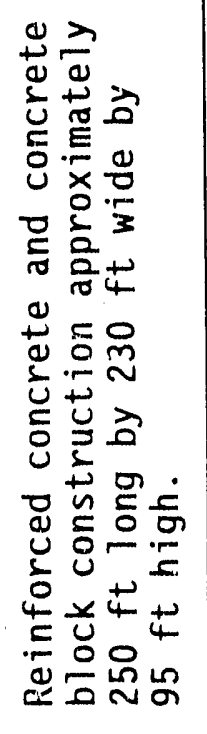 & 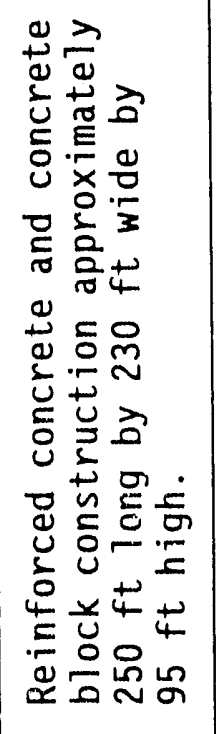 & 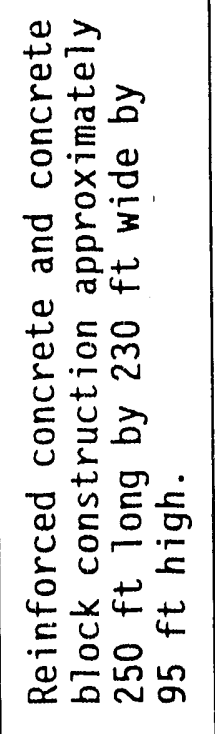 & 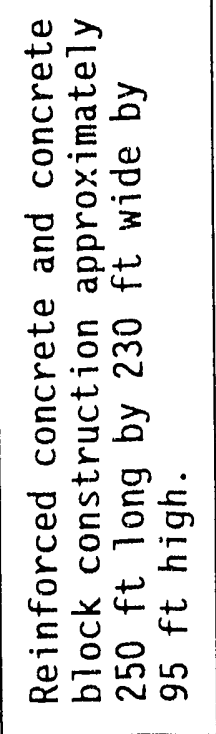 & 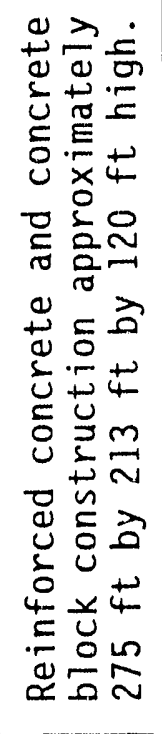 \\
\hline 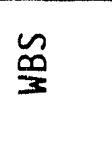 & $\begin{array}{l}\text { 怘 } \\
\text { 号 }\end{array}$ & $\begin{array}{l}\widetilde{D} \\
\text { Ф̊) }\end{array}$ & 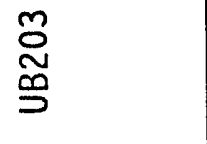 & $\begin{array}{l}\text { 莒 } \\
\text { 号 }\end{array}$ & $\begin{array}{l}\text { 足 } \\
\text { 号 }\end{array}$ & 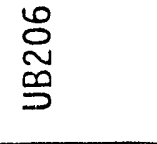 \\
\hline $\begin{array}{l}\text { 总 } \\
\text { o } \\
\text { ․․ㅁ }\end{array}$ & 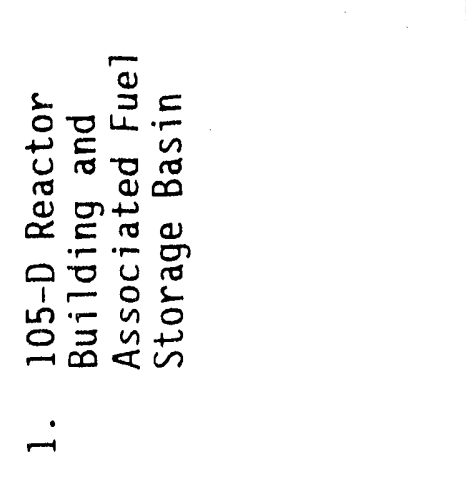 & 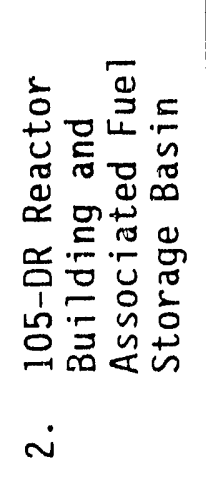 & 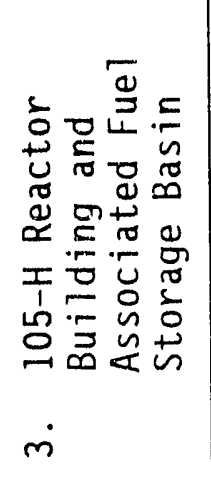 & 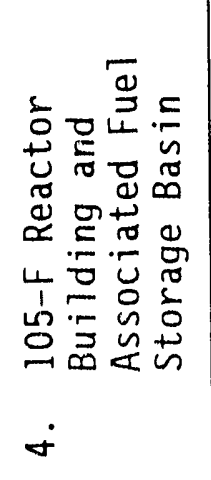 & 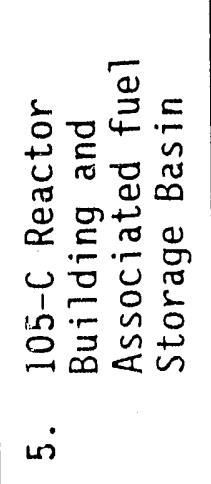 & 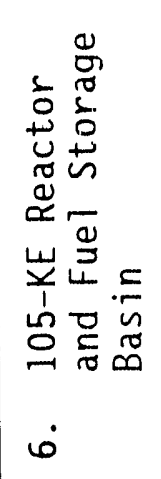 \\
\hline
\end{tabular}


A.2. 100 AREA REACTORS. (sheet 2 of 3 )

\begin{tabular}{|c|c|c|c|c|c|c|}
\hline 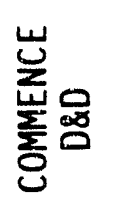 & $\begin{array}{l}\stackrel{m}{D} \\
\text { ¿̀ }\end{array}$ & $\begin{array}{l}\stackrel{2}{\circ} \\
\text { ¿ } \\
亡\end{array}$ & $\begin{array}{l}8 \\
\frac{8}{6} \\
\frac{7}{4}\end{array}$ & 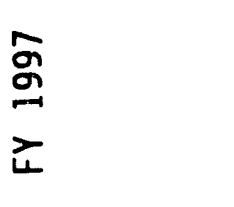 & $\begin{array}{l}\text { ğ } \\
\text { ঠे }\end{array}$ & $\begin{array}{l}\text { જ̆ } \\
\text { б }\end{array}$ \\
\hline 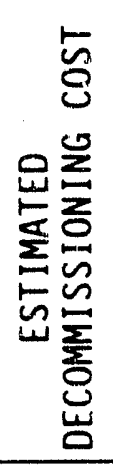 & 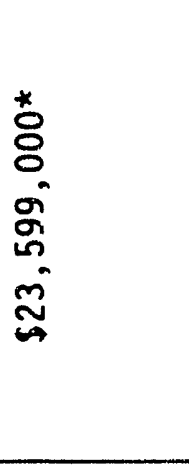 & 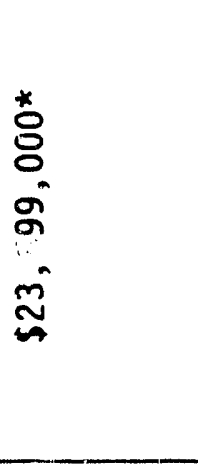 & $\begin{array}{l}8 \\
8 \\
8 \\
\stackrel{8}{0} \\
\text { ñ } \\
\text { in }\end{array}$ & $\begin{array}{l}8 \\
8 \\
\text { ñ } \\
n\end{array}$ & 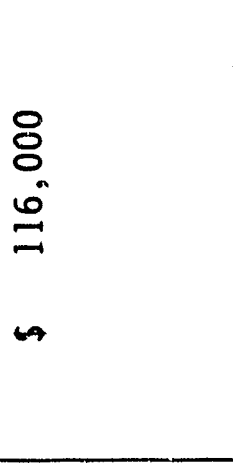 & $\begin{array}{l}8 \\
8 \\
0 \\
\emptyset \\
\cdots\end{array}$ \\
\hline 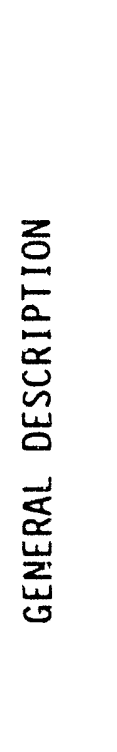 & 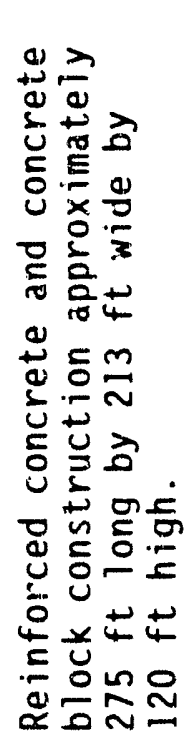 & 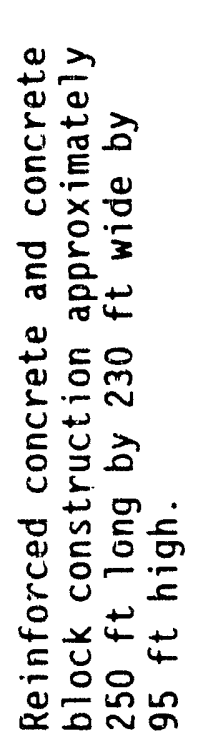 & 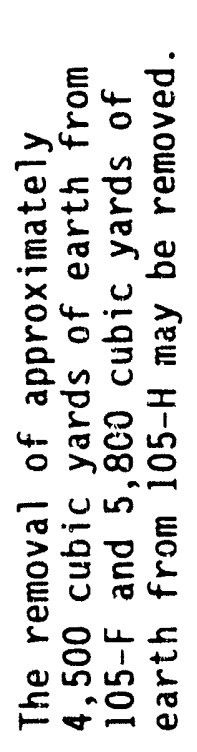 & 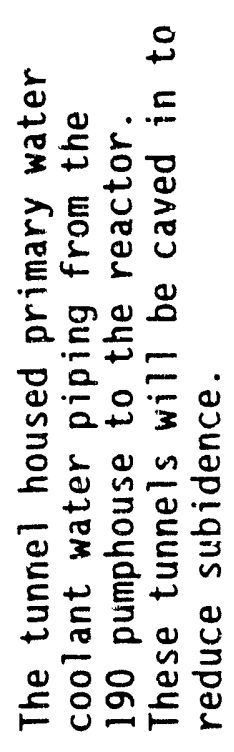 & 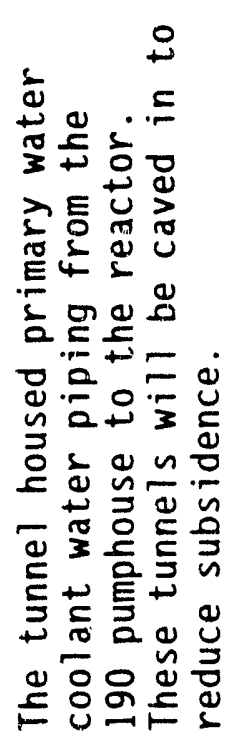 & 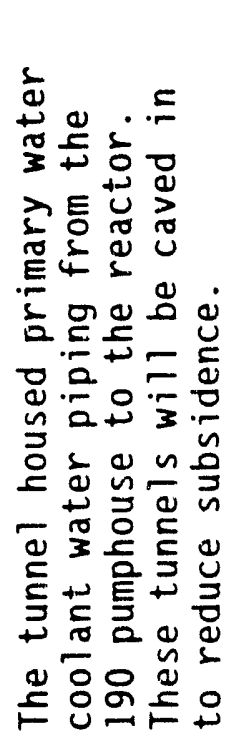 \\
\hline$\stackrel{\mathscr{m}}{\underline{x}}$ & 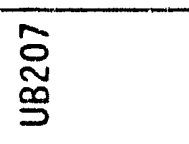 & 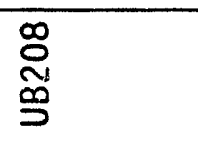 & 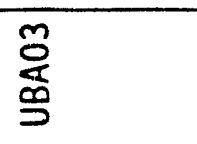 & $\begin{array}{l}\stackrel{\sim}{\sim} \\
\stackrel{\mathscr{O}}{\supset}\end{array}$ & $\frac{n}{\sim}$ & $\frac{\mathscr{\sigma}}{\widetilde{g}}$ \\
\hline 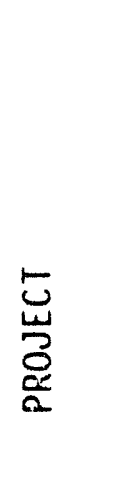 & 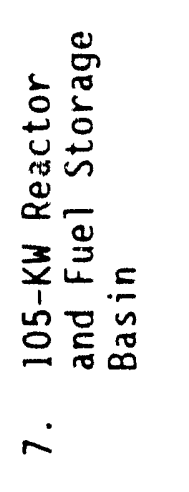 & 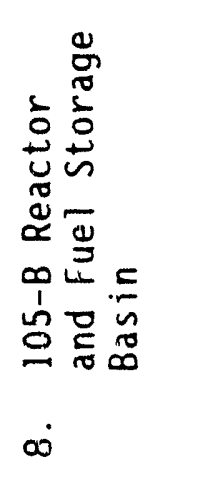 & 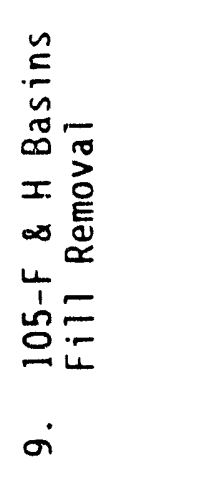 & 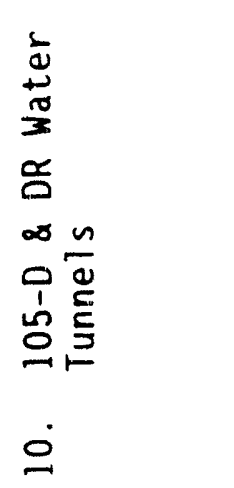 & 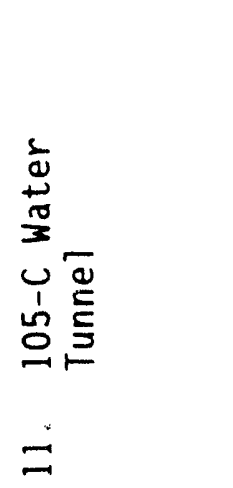 & 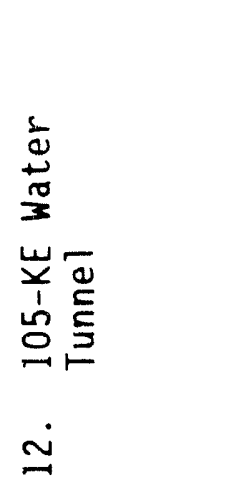 \\
\hline
\end{tabular}


WHC-EP-0231-3

A.2 100 AREA REACTORS. (sheet 3 of 3 )

\begin{tabular}{|c|c|c|c|}
\hline 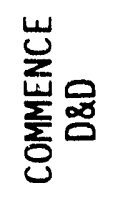 & $\begin{array}{l}\text { बे } \\
2 \\
2\end{array}$ & $\frac{\sigma}{2}$ & \\
\hline 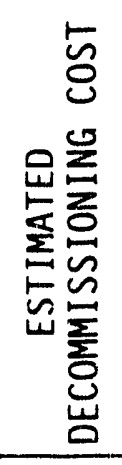 & 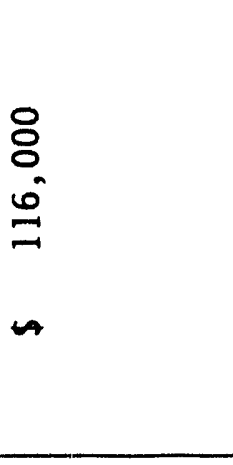 & $\begin{array}{l}\stackrel{8}{0} \\
\stackrel{0}{ٍ} \\
\cdots\end{array}$ & $\theta$ \\
\hline 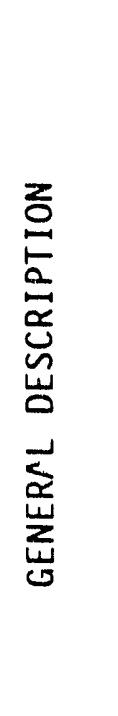 & 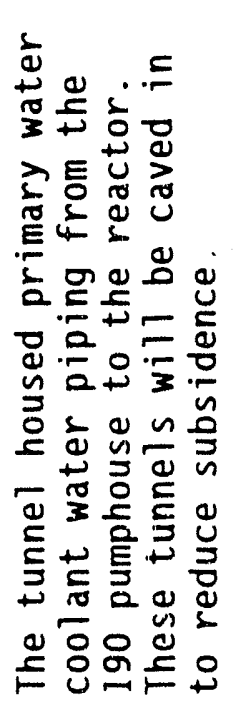 & 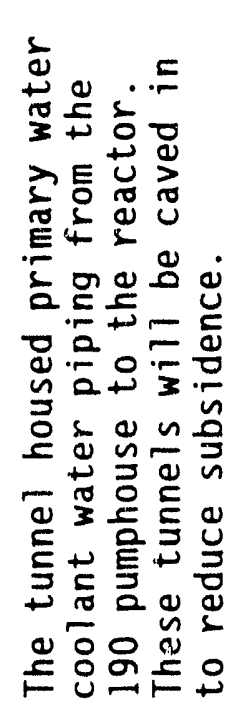 & 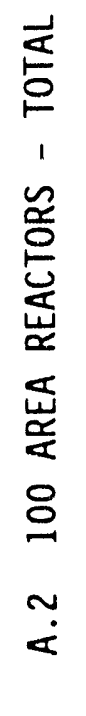 \\
\hline 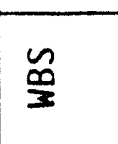 & 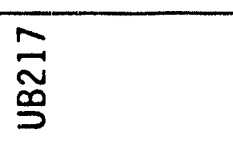 & $\stackrel{\infty}{\underset{\sim}{\sim}}$ & \\
\hline 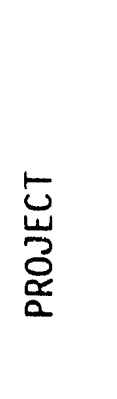 & 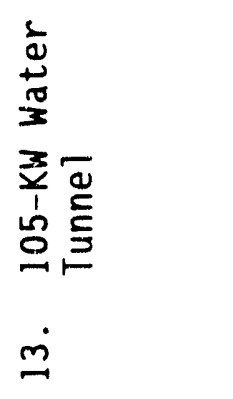 & 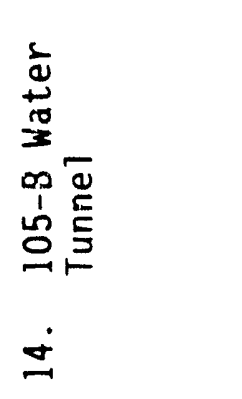 & \\
\hline
\end{tabular}


A.3 100 AREA ANCILLARIES. (sheet 1 of 4 )

\begin{tabular}{|c|c|c|c|c|c|c|}
\hline 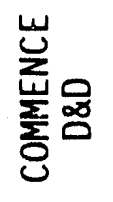 & $\begin{array}{l}\stackrel{2}{2} \\
2 \\
\longleftarrow\end{array}$ & 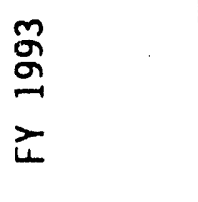 & $\begin{array}{l}\text { \%̆ } \\
\text { જ } \\
z\end{array}$ & $\begin{array}{l}\text { ğ } \\
\text { こ }\end{array}$ & $\begin{array}{l}\mathscr{2} \\
\text { g } \\
\text { خ }\end{array}$ & 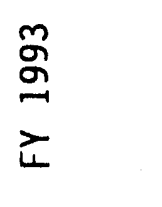 \\
\hline 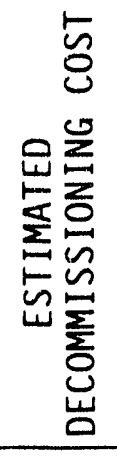 & $\begin{array}{l}8 \\
0 \\
0 \\
\vdots \\
\text { i }\end{array}$ & $\begin{array}{l}8 \\
0 \\
0 \\
\vdots \\
\sim\end{array}$ & $\begin{array}{l}8 \\
0 \\
\text { ì } \\
\text { n }\end{array}$ & $\begin{array}{l}8 \\
8 \\
n \\
n\end{array}$ & 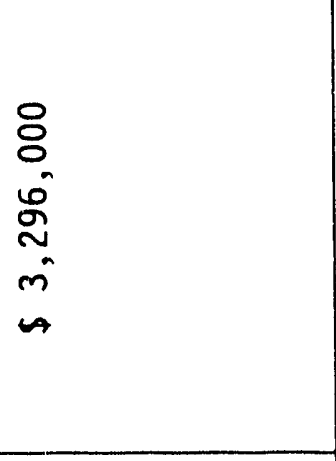 & 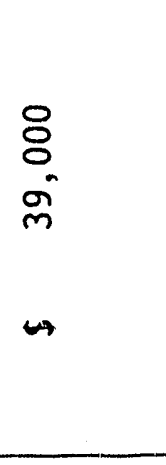 \\
\hline 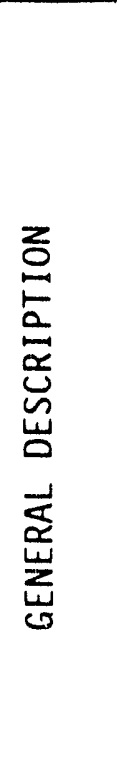 & 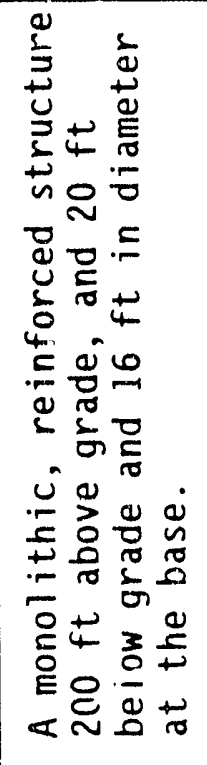 & 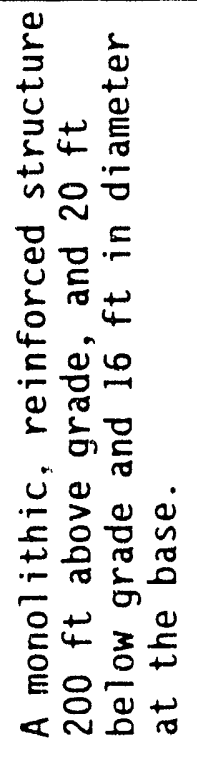 & 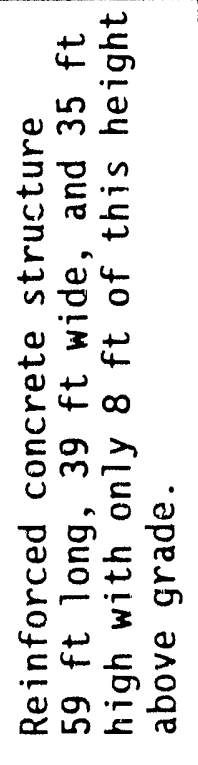 & 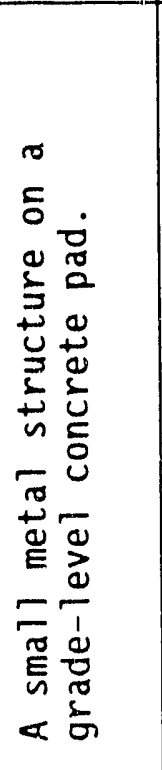 & 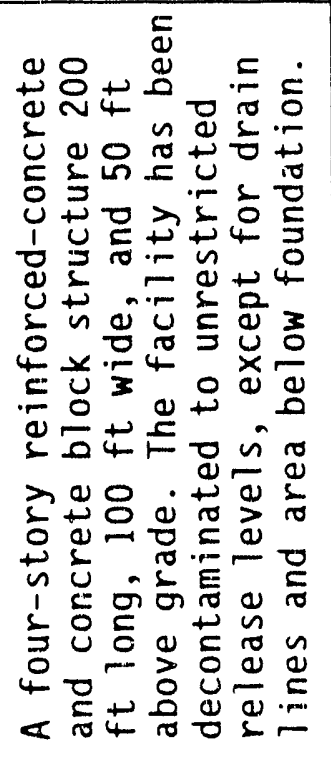 & 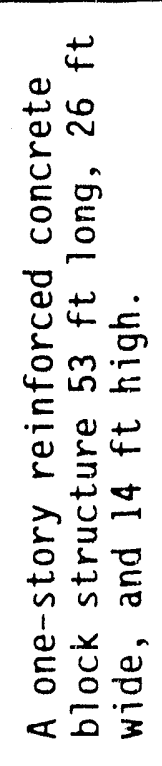 \\
\hline$\tilde{\mathscr{m}}$ & $\frac{\vec{Q}}{5}$ & $\begin{array}{l}\tilde{O} \\
\stackrel{\delta}{S}\end{array}$ & $\begin{array}{l} \\
\\
\end{array}$ & $\varliminf_{0}^{m}$ & 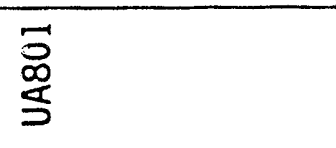 & 容 \\
\hline $\begin{array}{l}\text { 吕 } \\
\text { O } \\
\text { \& }\end{array}$ & 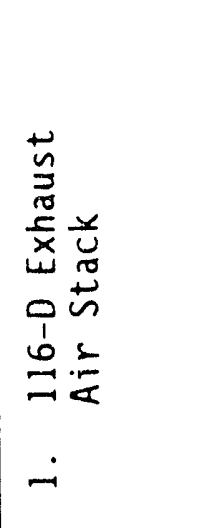 & 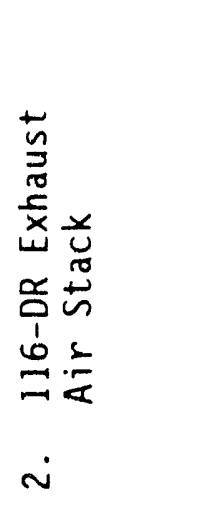 & 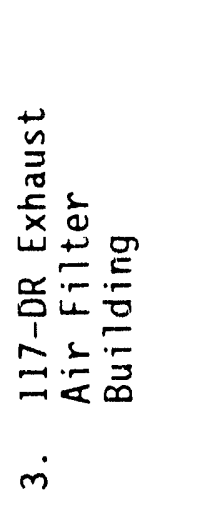 & 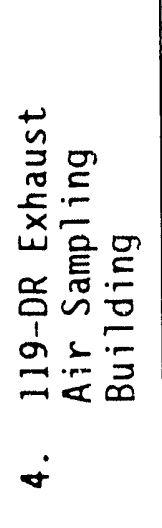 & 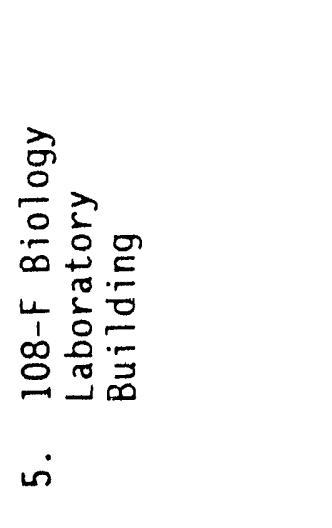 & 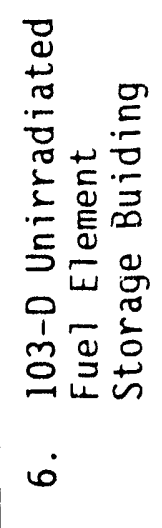 \\
\hline
\end{tabular}


A.3 100 AREA ANCILLARIES. (sheet 2 of 4 )

\begin{tabular}{|c|c|c|c|c|}
\hline 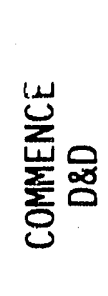 & 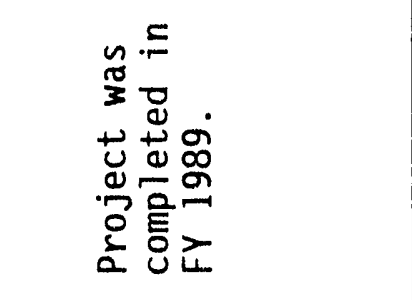 & 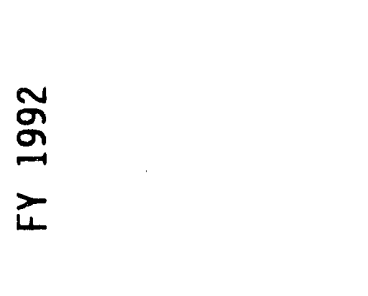 & $\begin{array}{l}\text { 号 } \\
\text { خ }\end{array}$ & 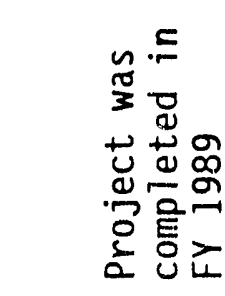 \\
\hline 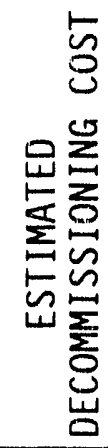 & $\begin{array}{l}8 \\
8 \\
0 \\
0 \\
0 \\
0\end{array}$ & 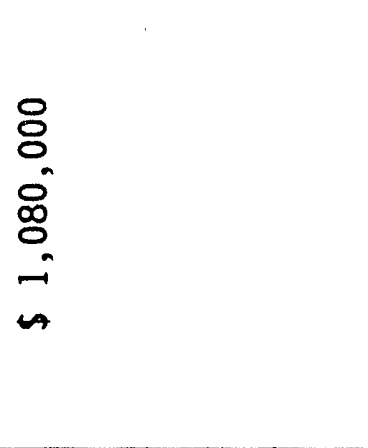 & 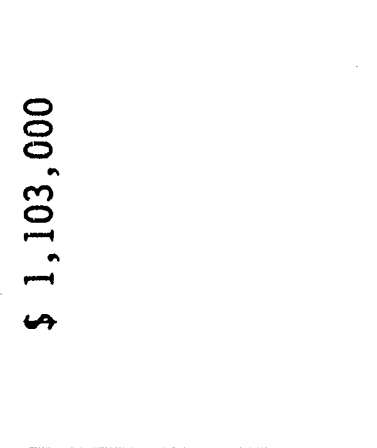 & 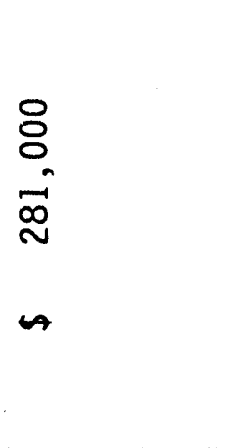 \\
\hline 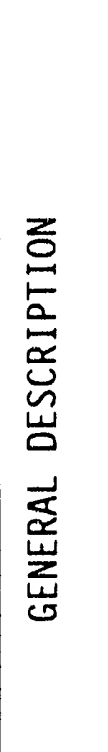 & 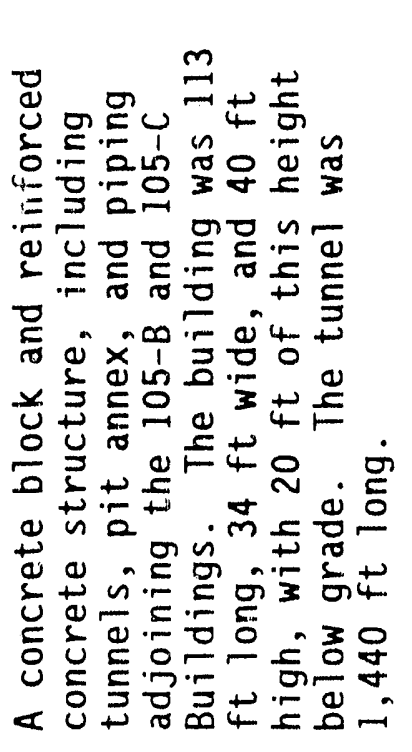 & 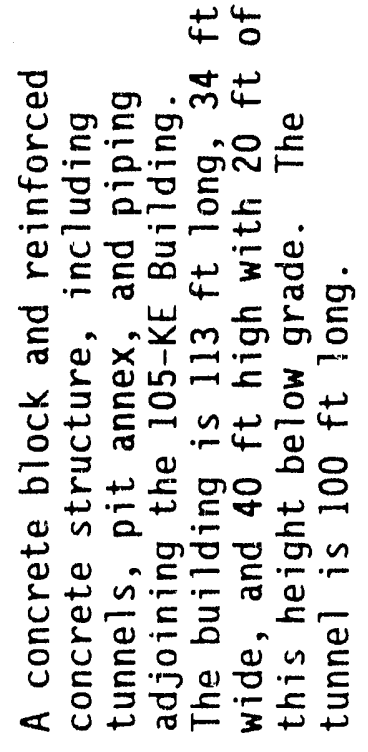 & 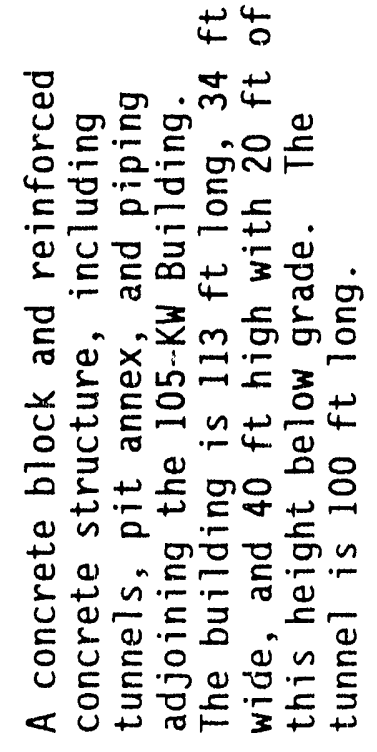 & 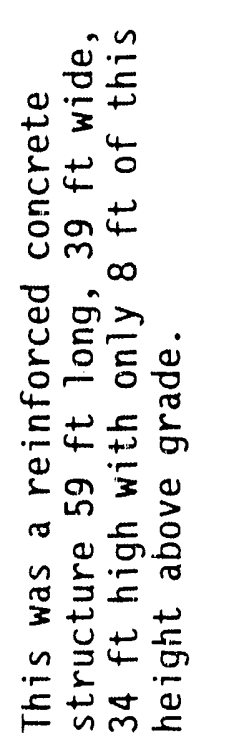 \\
\hline$\widetilde{\mathscr{m}}$ & 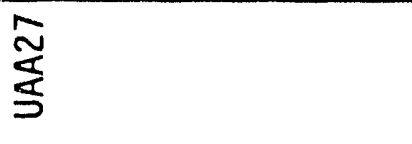 & 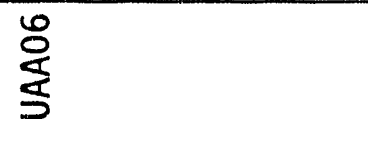 & 道 & 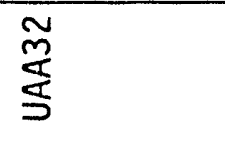 \\
\hline 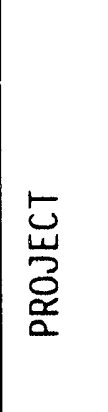 & 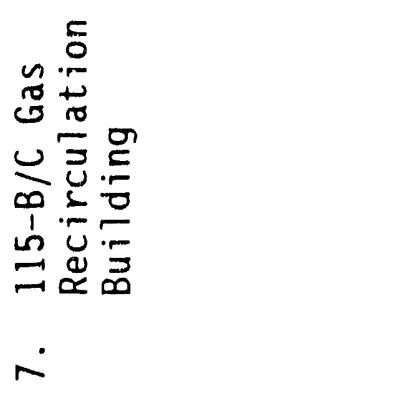 & 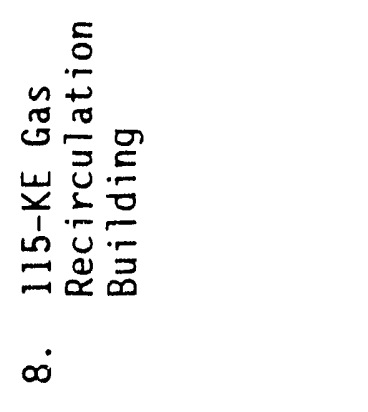 & 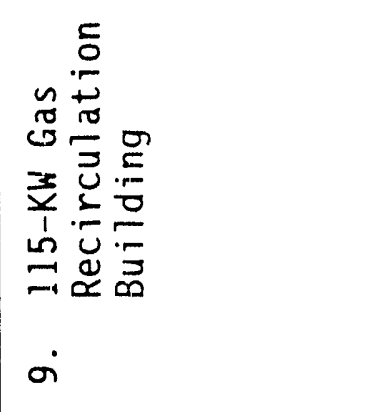 & 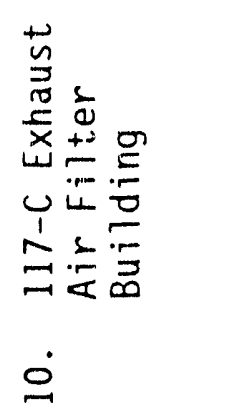 \\
\hline
\end{tabular}


A.3 100 AREA ANCILLARIES. (sheet 3 of 4 )

\begin{tabular}{|c|c|c|c|c|c|c|c|}
\hline 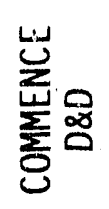 & $\begin{array}{l}\text { Оू } \\
\text { 立 }\end{array}$ & $\begin{array}{l}\text { જે } \\
\text { ปे }\end{array}$ & $\begin{array}{l}\text { Оू } \\
\text { ঠे }\end{array}$ & $\begin{array}{l}\text { \% } \\
\text { g } \\
\text { 乙 }\end{array}$ & $\begin{array}{l}\text { Oે } \\
\text { O } \\
\text { خ্் }\end{array}$ & $\begin{array}{l}\text { \%̆ } \\
\text { 号 }\end{array}$ & $\begin{array}{l}\stackrel{m}{\sigma} \\
\stackrel{-}{2} \\
z \\
z\end{array}$ \\
\hline 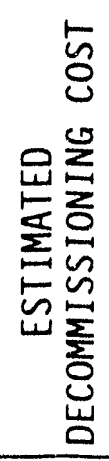 & $\begin{array}{l}\text { Oे } \\
\text { d } \\
\text { n }\end{array}$ & $\begin{array}{l}\stackrel{8}{0} \\
\stackrel{n}{*} \\
\stackrel{\sim}{*} \\
n\end{array}$ & $\begin{array}{l}8 \\
8 \\
\stackrel{\circ}{0} \\
\text { N }\end{array}$ & 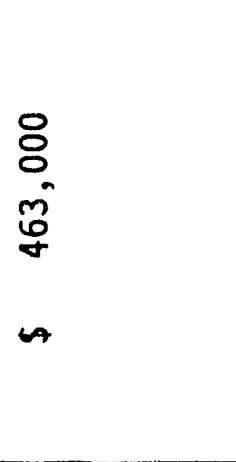 & $\begin{array}{l}8 \\
8 \\
0 \\
6 \\
0\end{array}$ & 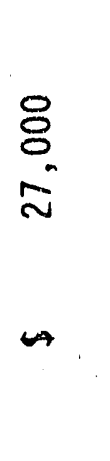 & $\begin{array}{l}8 \\
8 \\
\text { i } \\
\end{array}$ \\
\hline 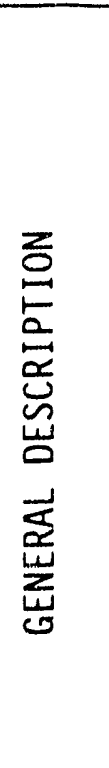 & 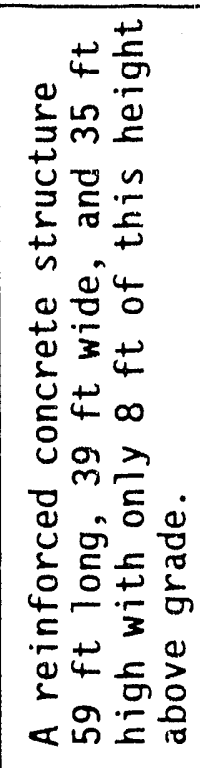 & 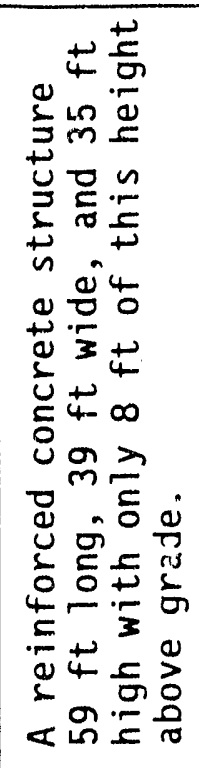 & 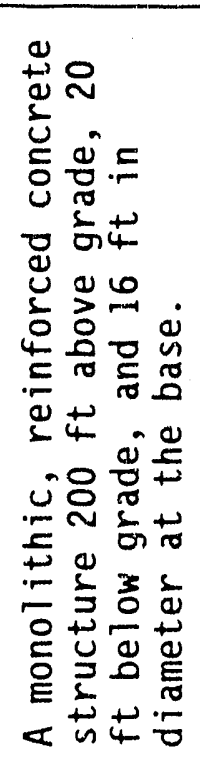 & 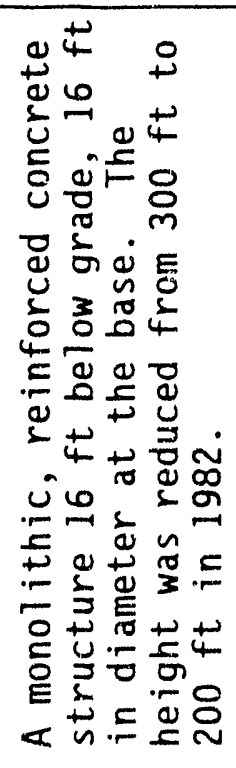 & 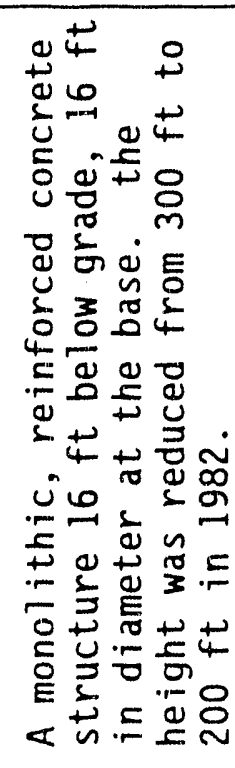 & 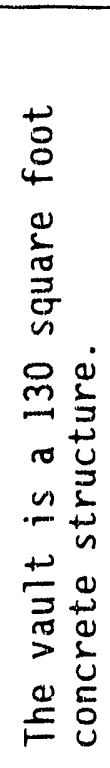 & 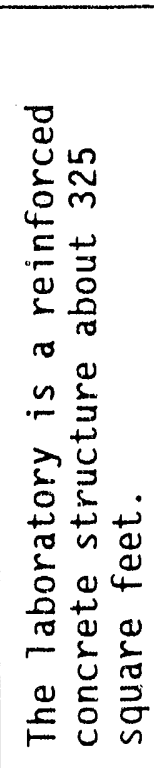 \\
\hline 愛 & $\begin{array}{l}0 \\
0 \\
\frac{0}{5} \\
\end{array}$ & $\begin{array}{l}9 \\
0 \\
0 \\
0\end{array}$ & 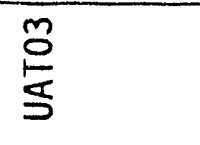 & $\begin{array}{l}\text { J } \\
\text { 兵 }\end{array}$ & $\begin{array}{l}\stackrel{\mathscr{O}}{\circ} \\
\stackrel{\sigma}{S}\end{array}$ & 客 & 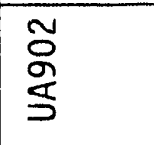 \\
\hline 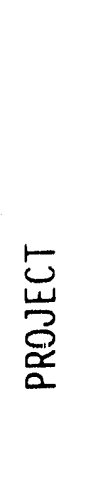 & 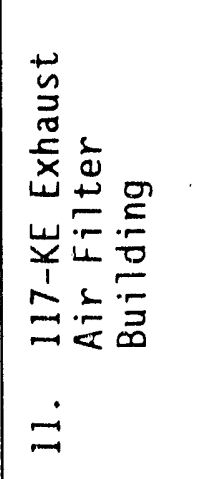 & 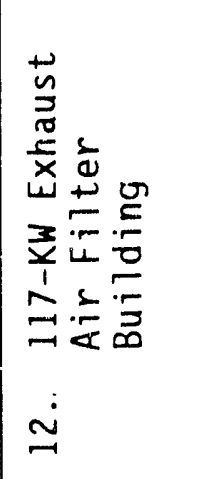 & 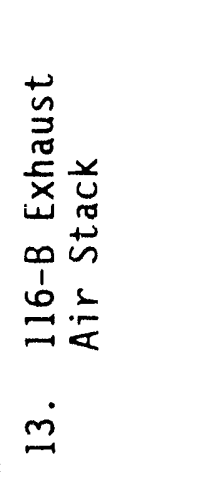 & 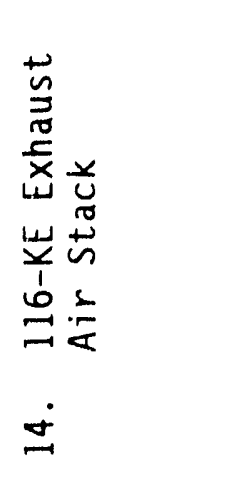 & 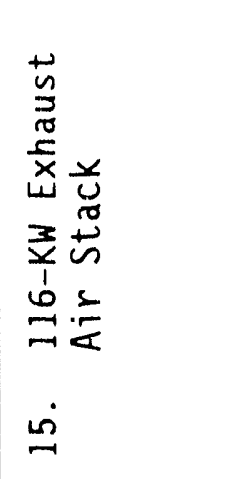 & 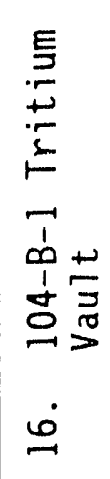 & 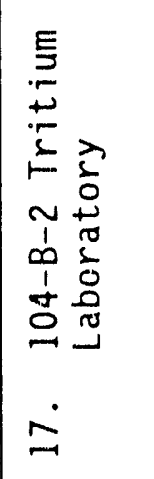 \\
\hline
\end{tabular}




\section{A.3 100 AREA ANCILLARIES. (sheet 4 of 4 )}

\begin{tabular}{|c|c|c|c|c|c|c|}
\hline 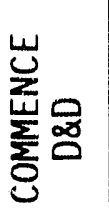 & $\begin{array}{l}\text { ğ } \\
\text { ป } \\
\text { z }\end{array}$ & 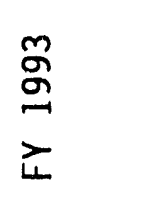 & 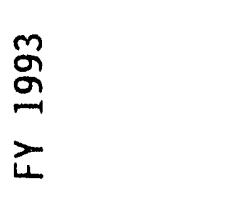 & $\begin{array}{l}\text { જ̆ } \\
\text { Љ } \\
\text { خ }\end{array}$ & 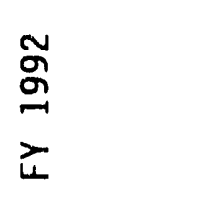 & \\
\hline 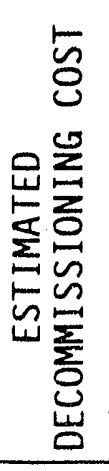 & $\begin{array}{l}8 \\
8 \\
n \\
n\end{array}$ & $\begin{array}{l}8 \\
8 \\
n \\
n \\
n\end{array}$ & $\begin{array}{l}8 \\
8 \\
m \\
\stackrel{n}{0} \\
m^{n} \\
m \\
n\end{array}$ & $\begin{array}{l}8 \\
\text { on } \\
\text { n } \\
n\end{array}$ & $\begin{array}{l}\stackrel{8}{0} \\
\stackrel{\circ}{\infty} \\
\stackrel{-}{-1} \\
\sim\end{array}$ & \\
\hline 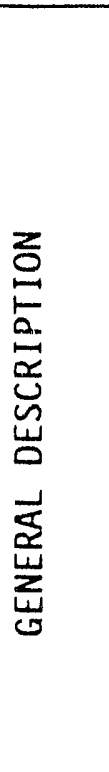 & 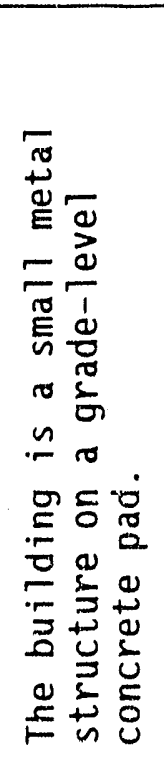 & 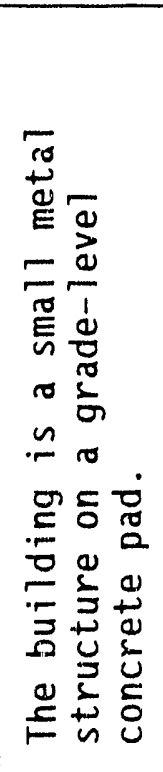 & 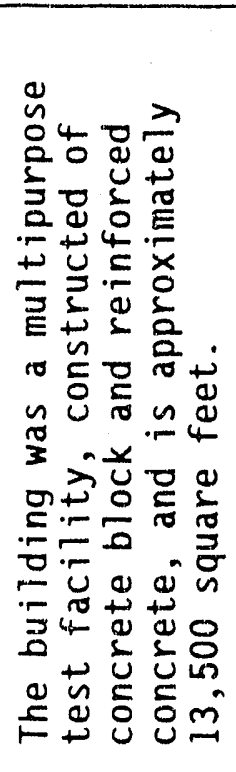 & 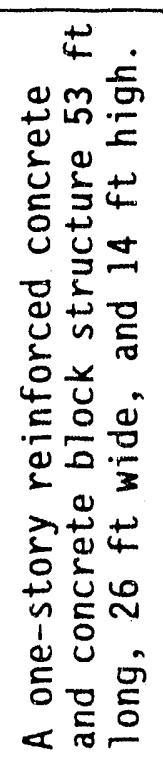 & 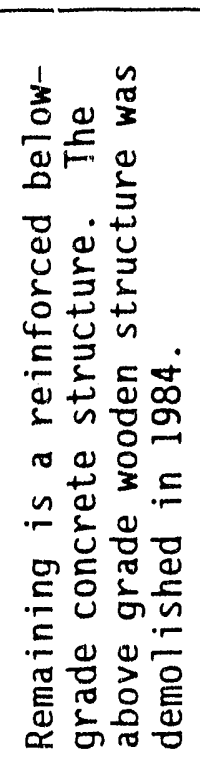 & 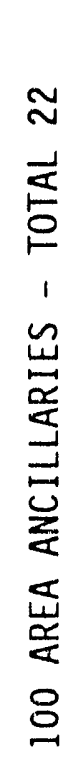 \\
\hline$\stackrel{\mathscr{\mathscr { O }}}{\Im}$ & 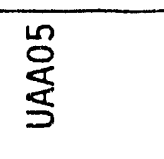 & 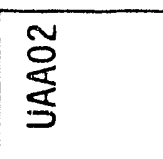 & $\begin{array}{l}\text { 온 } \\
\text { 䒺 }\end{array}$ & $\begin{array}{l}0 \\
0 \\
0 \\
\end{array}$ & $\begin{array}{l}\text { m. } \\
\text { ஜ } \\
\text { Sั }\end{array}$ & $\stackrel{m}{\dot{\alpha}}$ \\
\hline $\begin{array}{l}\text { 岀 } \\
\text { Oे } \\
\stackrel{\alpha}{2}\end{array}$ & 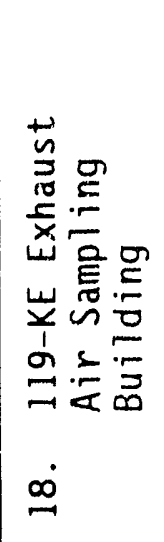 & 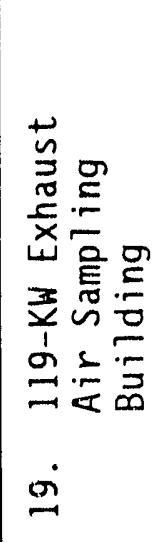 & 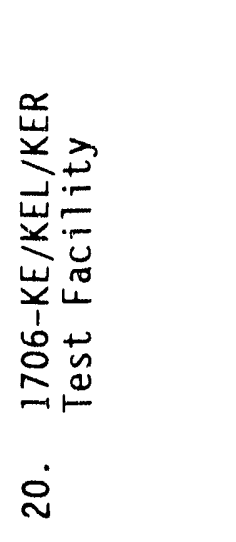 & 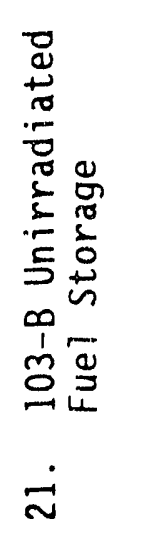 & 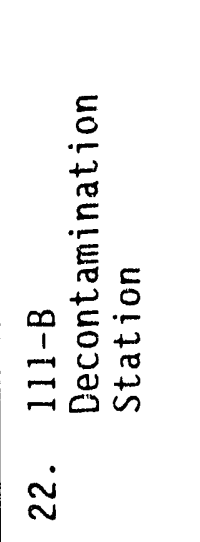 & \\
\hline
\end{tabular}


A.4 100 AREA EFFLUENTS. (sheet 1 of 4)

\begin{tabular}{|c|c|c|c|c|c|c|}
\hline 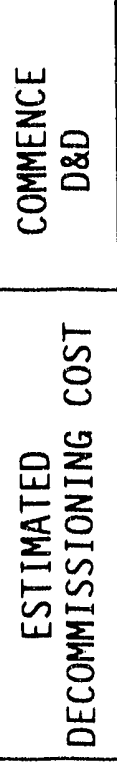 & 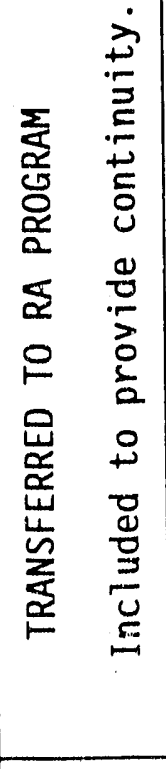 & 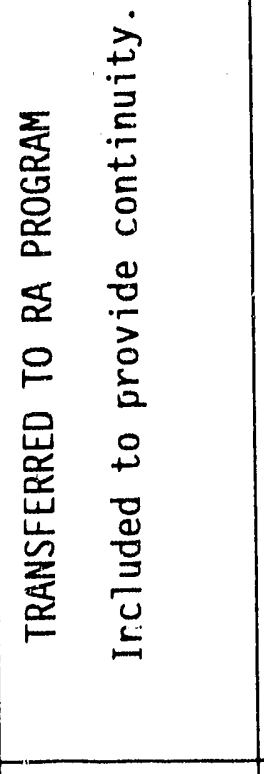 & 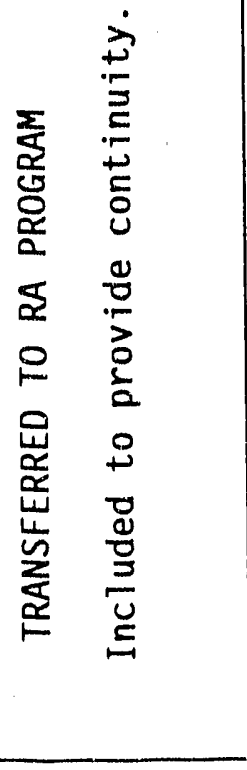 & 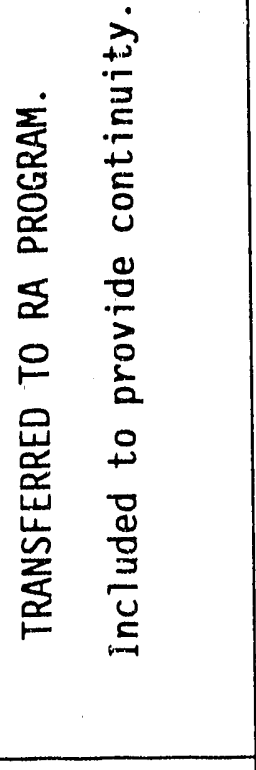 & 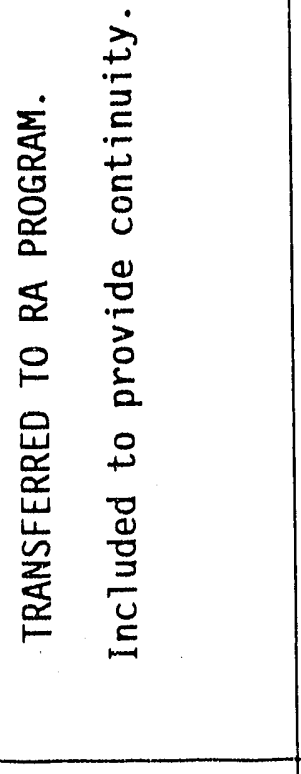 & 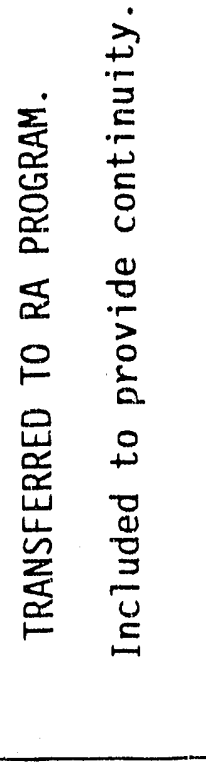 \\
\hline 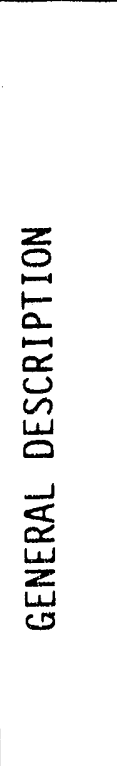 & 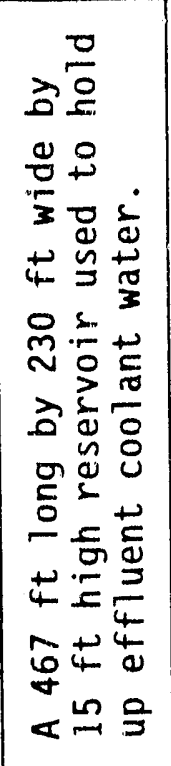 & 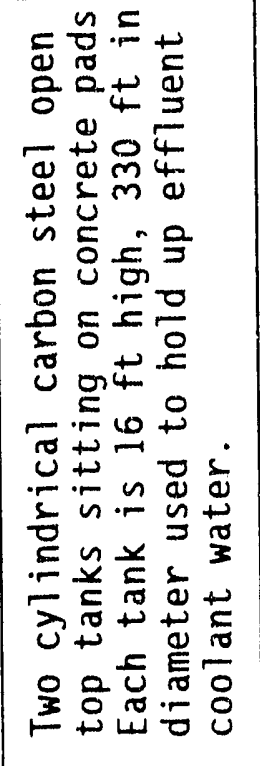 & 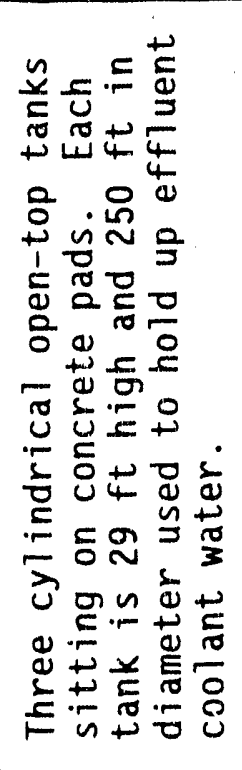 & 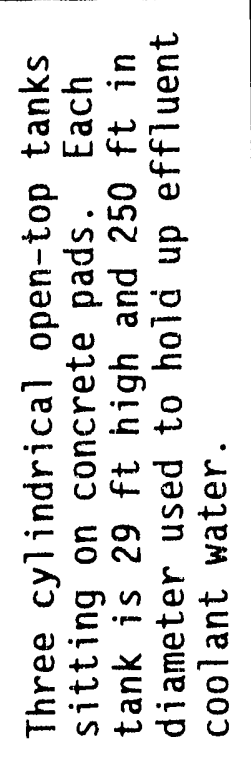 & 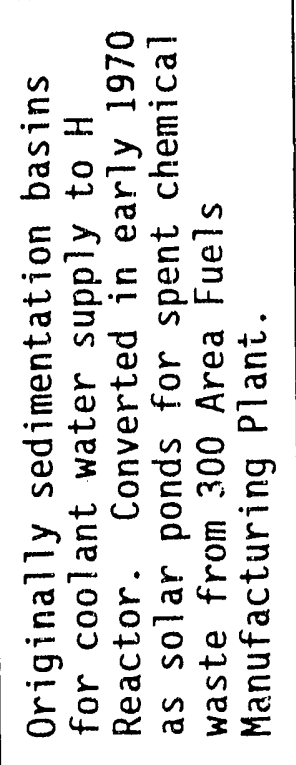 & 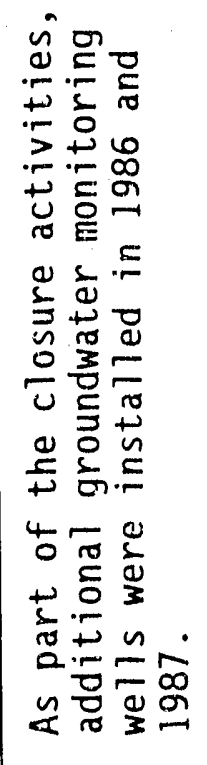 \\
\hline$\stackrel{\mathscr{0}}{\widetilde{x}}$ & & & & & & \\
\hline $\begin{array}{l}\text { ․ } \\
\text { 号 } \\
\text { \& }\end{array}$ & 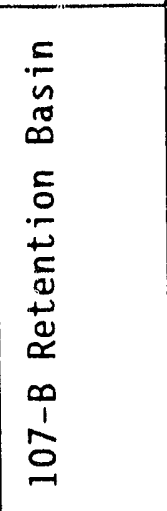 & 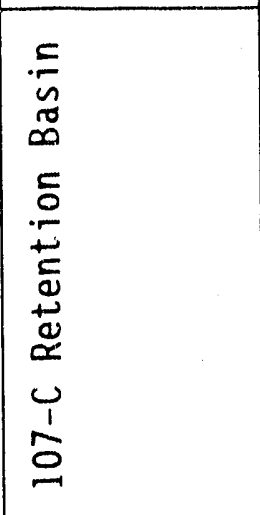 & 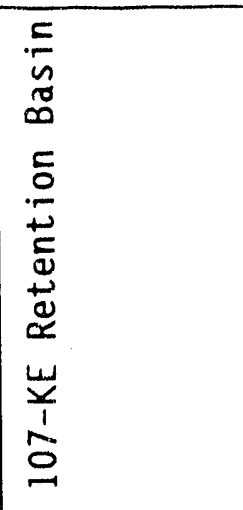 & 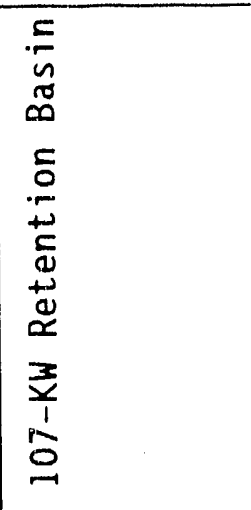 & 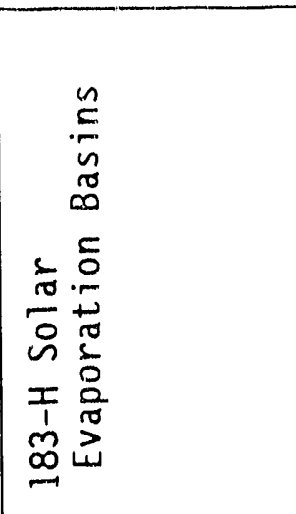 & 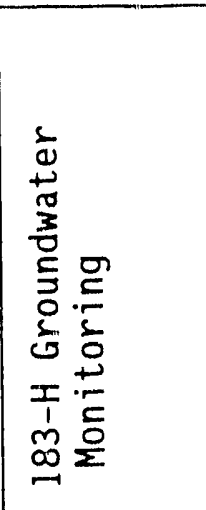 \\
\hline
\end{tabular}


A.4 100 AREA EFFLUENTS. (sheet 2 of 4 )

\begin{tabular}{|c|c|c|c|c|c|c|}
\hline 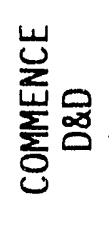 & 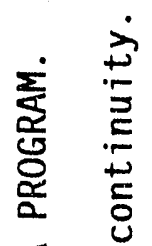 & 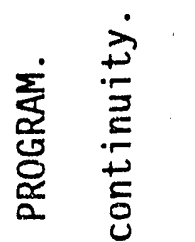 & 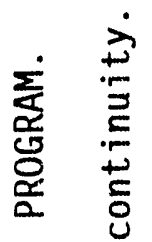 & 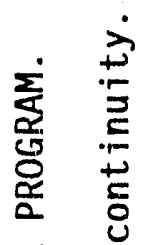 & 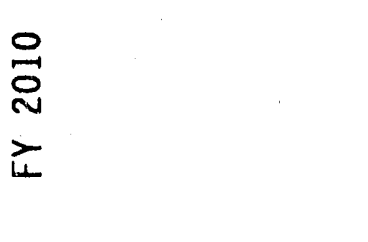 & 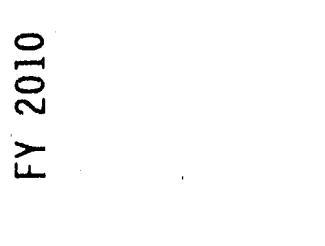 \\
\hline 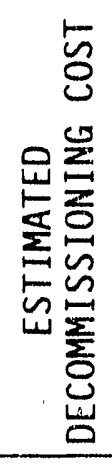 & 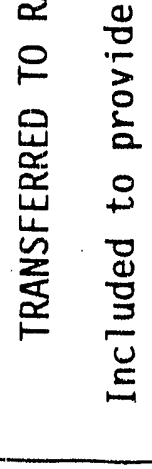 & 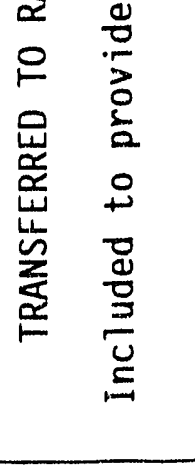 & 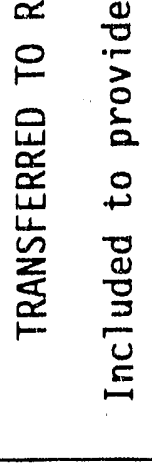 & 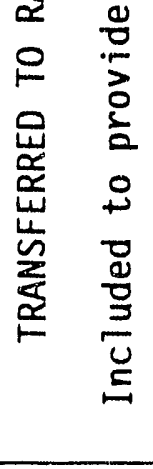 & $\begin{array}{l}8 \\
8 \\
\text { in } \\
\stackrel{m}{N}\end{array}$ & $\begin{array}{l}8 \\
8 \\
\stackrel{0}{N} \\
\stackrel{n}{N} \\
n\end{array}$ \\
\hline 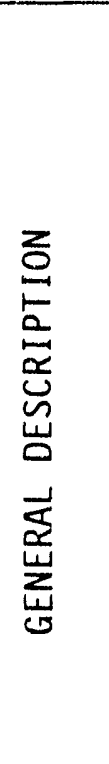 & 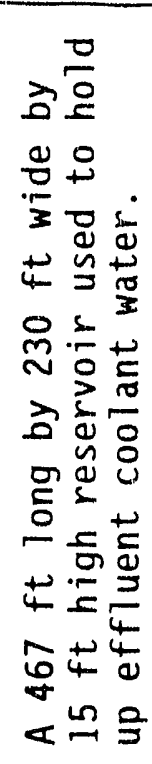 & 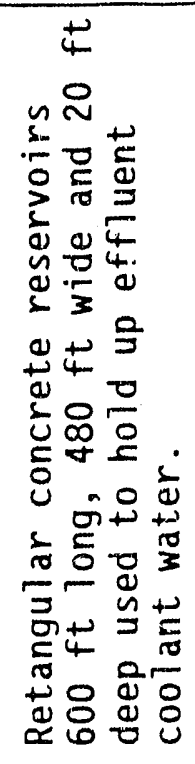 & 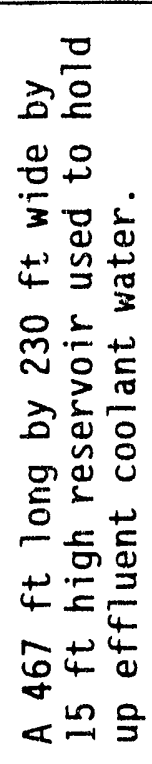 & 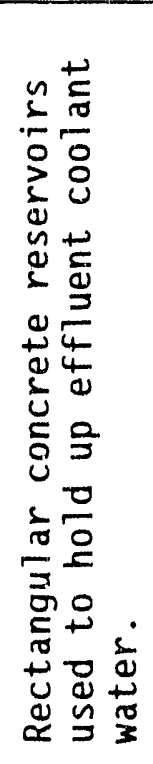 & 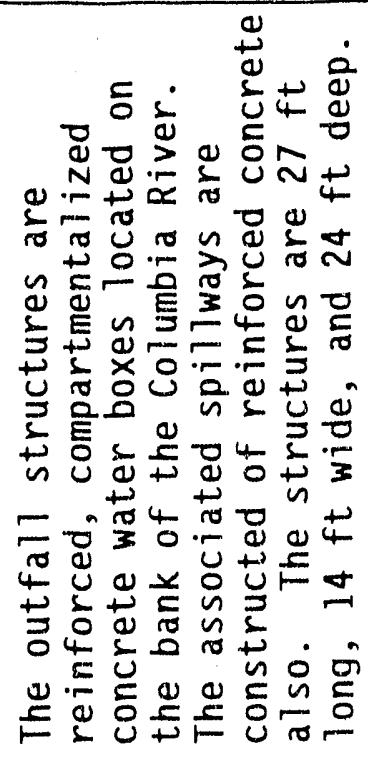 & 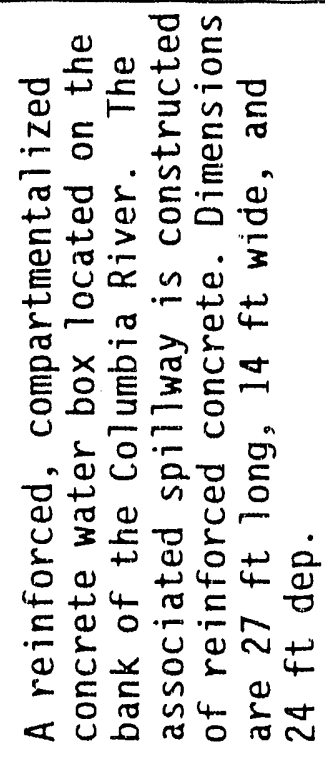 \\
\hline$\stackrel{\mathscr{m}}{\underline{3}}$ & & & & & 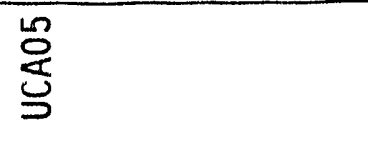 & 仓̊용 \\
\hline 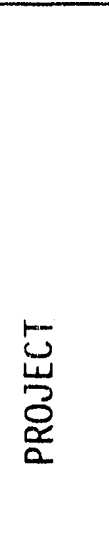 & 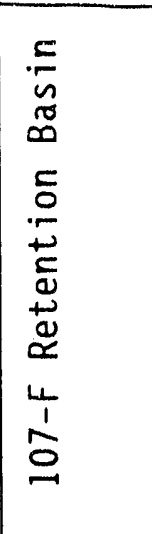 & 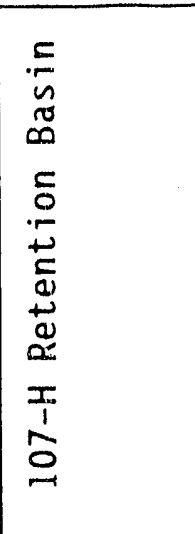 & 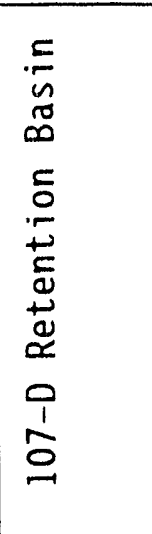 & 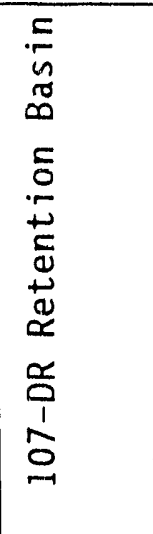 & 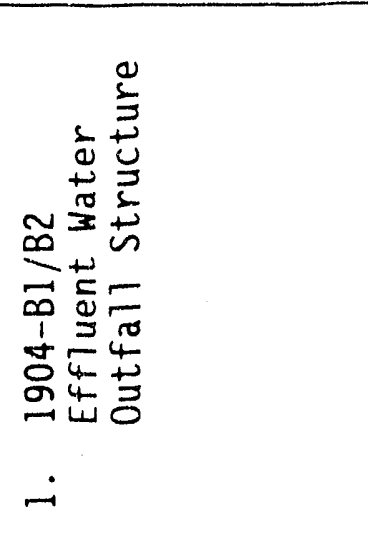 & 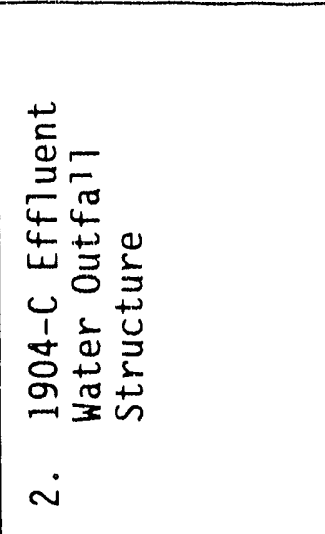 \\
\hline
\end{tabular}




\section{A.4 100 AREA EFFLUENTS. (sheet 3 of 4 )}

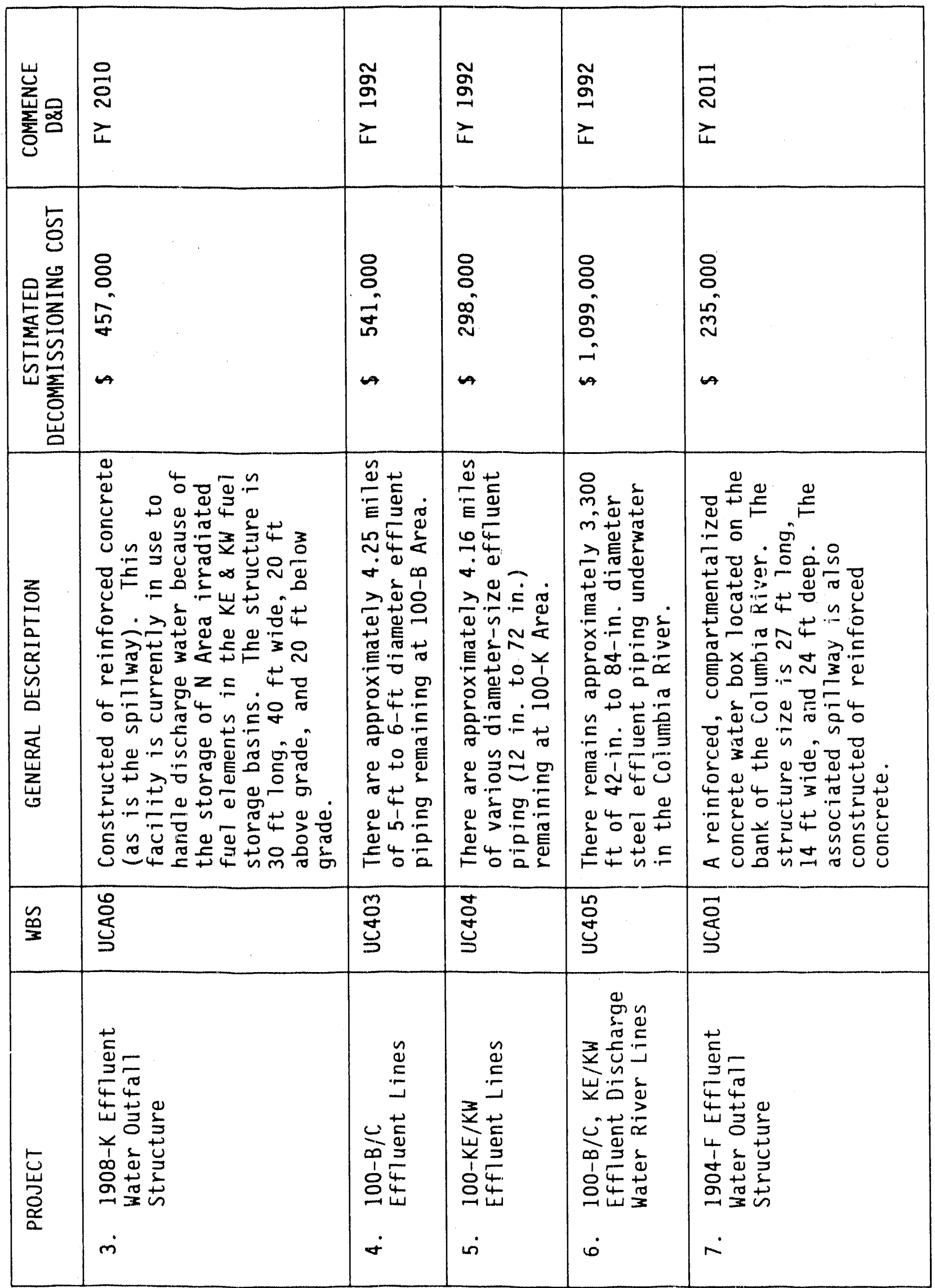


A.4 100 AREA EFFLUENTS. (sheet 4 of 4 )

\begin{tabular}{|c|c|c|c|c|c|c|}
\hline 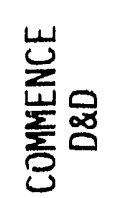 & $\begin{array}{l}\vec{\Xi} \\
\text { D } \\
\text { Zे }\end{array}$ & $\begin{array}{l}\bar{\Xi} \\
\text { N } \\
\text { Zे }\end{array}$ & $\begin{array}{l}\vec{Z} \\
\text { N } \\
\text { Zे }\end{array}$ & 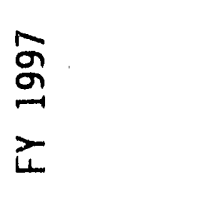 & $\begin{array}{l}\stackrel{0}{O} \\
\stackrel{N}{ } \\
⿱ 亠 䒑\end{array}$ & \\
\hline 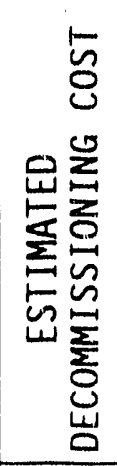 & $\begin{array}{l}\stackrel{8}{0} \\
\stackrel{\infty}{\sim} \\
\sim\end{array}$ & $\begin{array}{l}\stackrel{8}{0} \\
\stackrel{0}{N} \\
\stackrel{n}{N} \\
n\end{array}$ & $\begin{array}{l}\stackrel{8}{0} \\
\stackrel{0}{\sim} \\
\stackrel{\sim}{\sim} \\
\sim\end{array}$ & 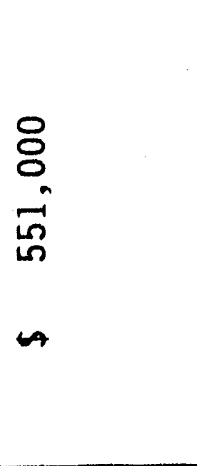 & 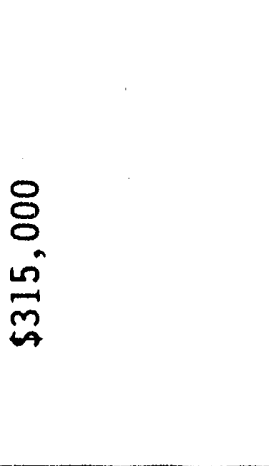 & \\
\hline 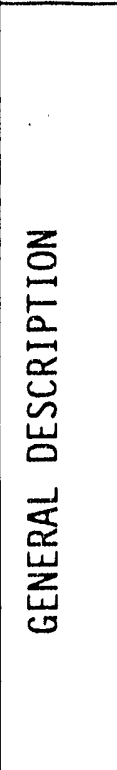 & 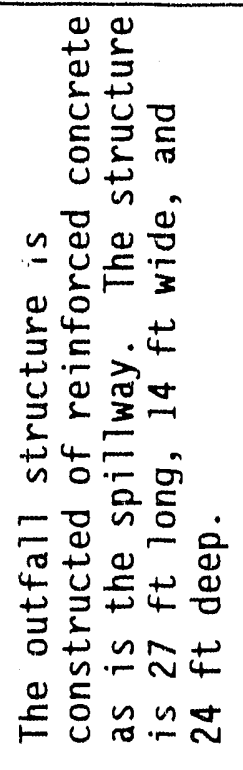 & 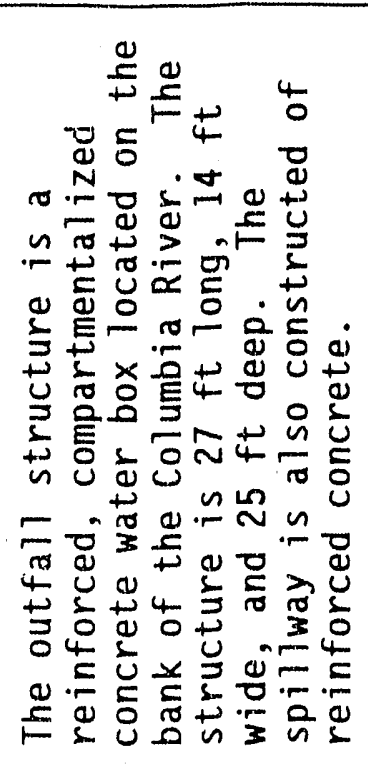 & 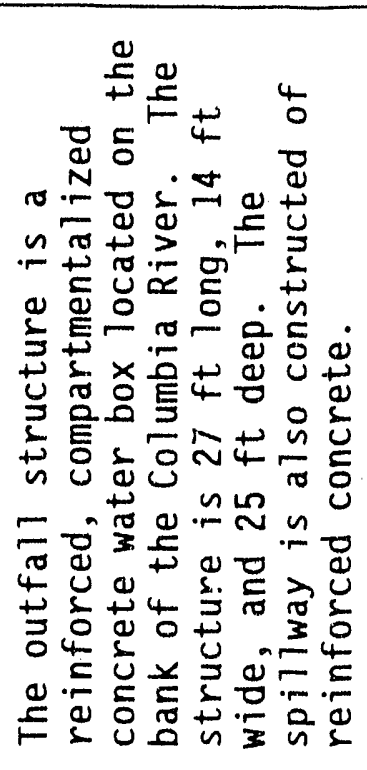 & 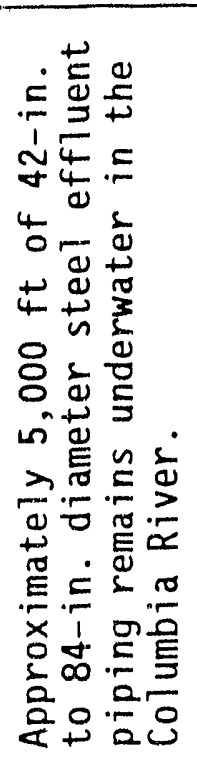 & 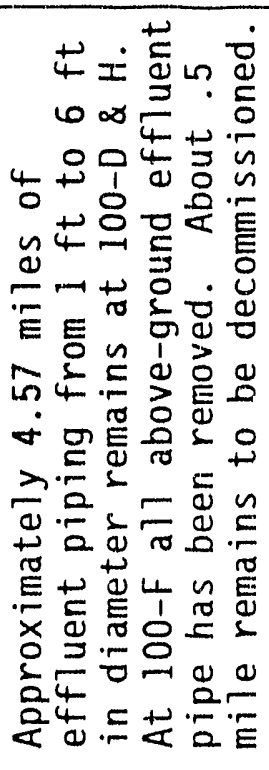 & \\
\hline 岗 & 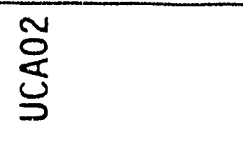 & 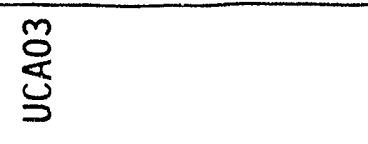 & 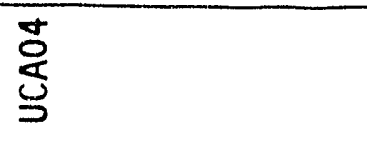 & 客 & $\begin{array}{l}\tilde{O} \\
\dot{y} \\
\text { J }\end{array}$ & \\
\hline \begin{tabular}{|l} 
\\
岁 \\
品 \\
\end{tabular} & 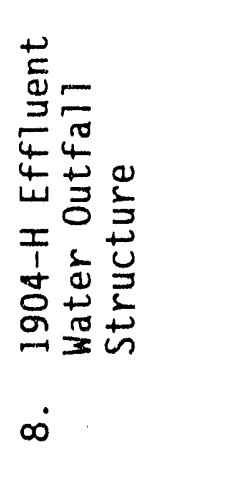 & 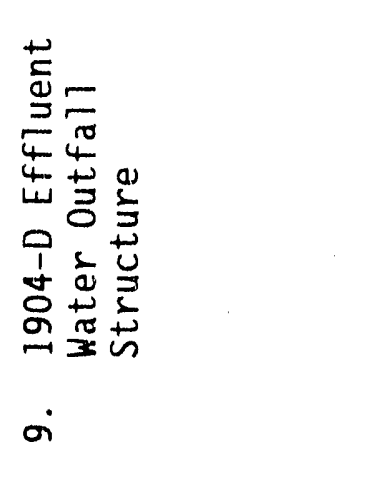 & 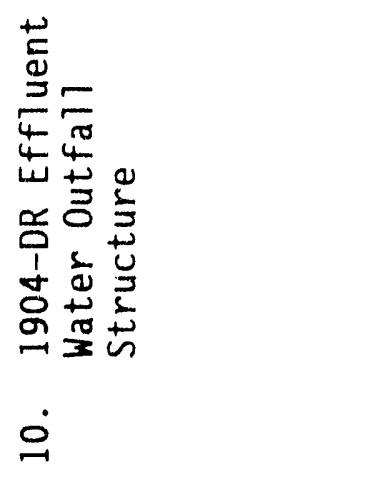 & 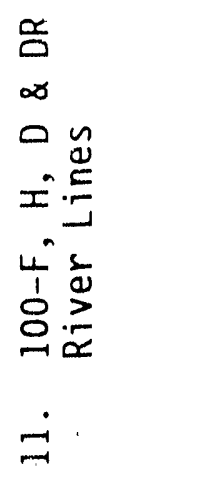 & 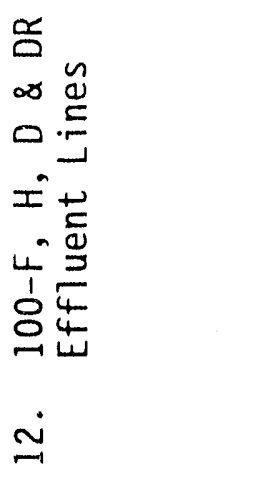 & \\
\hline
\end{tabular}


A.5 200 AREA MAJOR PROCESSING/SUPPORT BUILDINGS. (sheet 1 of 9 )

\begin{tabular}{|c|c|c|c|c|c|c|c|}
\hline 岕 & 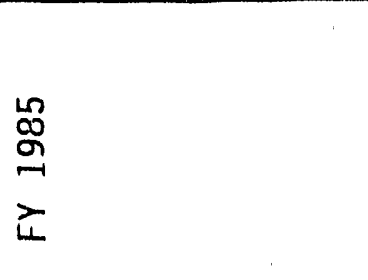 & 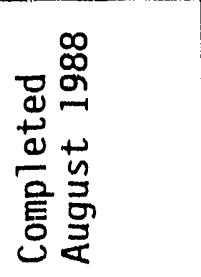 & 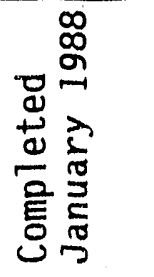 & 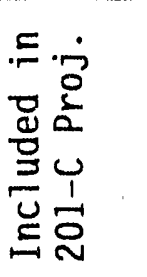 & 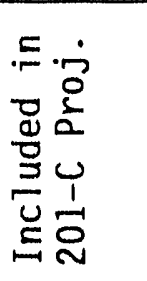 & 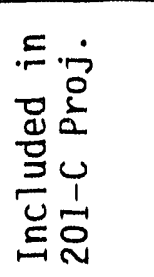 & 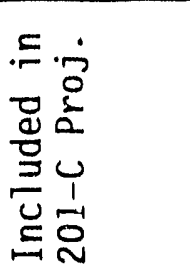 \\
\hline 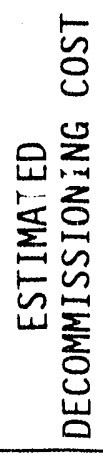 & 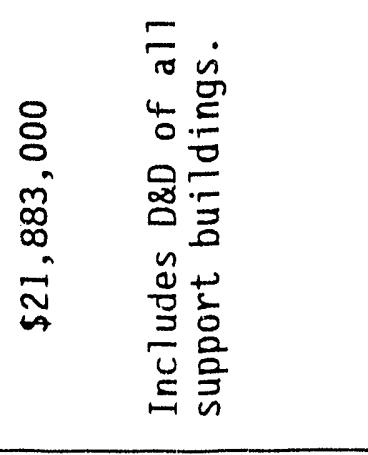 & 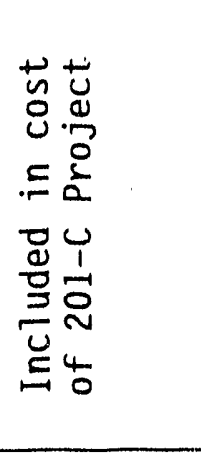 & 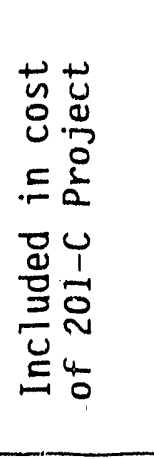 & 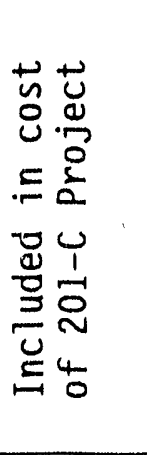 & 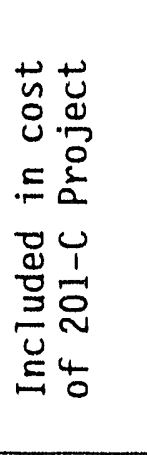 & 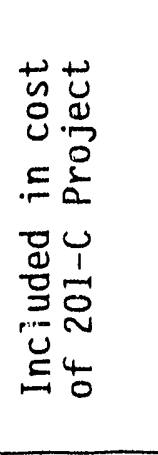 & 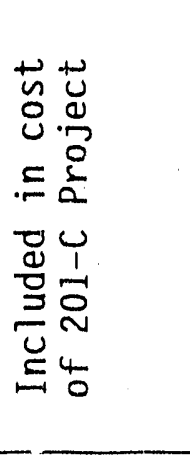 \\
\hline 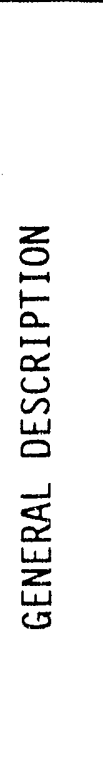 & 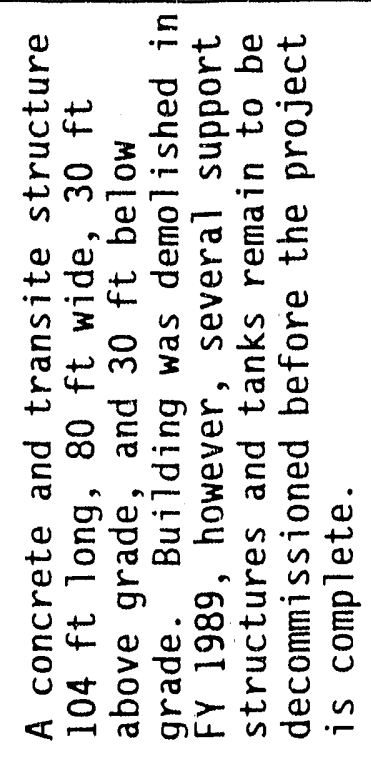 & 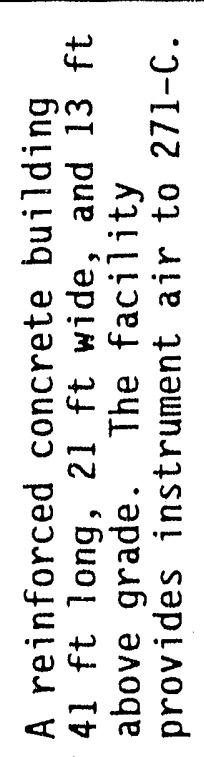 & 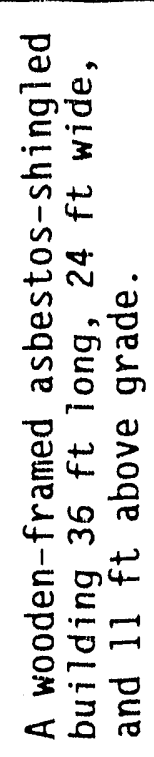 & 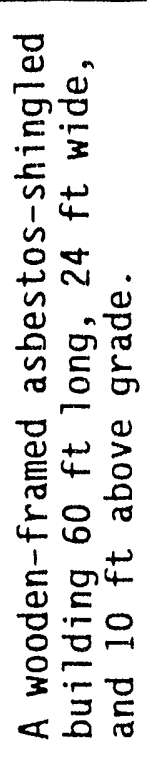 & 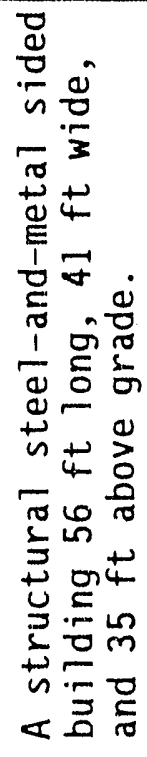 & 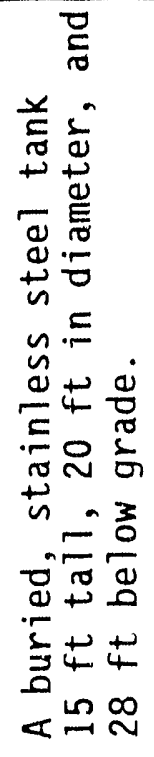 & 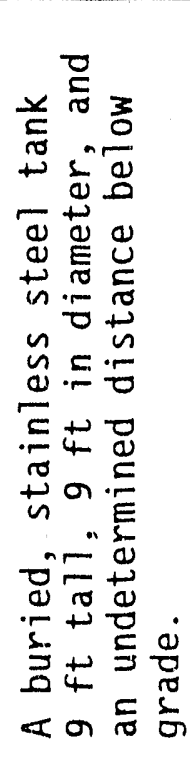 \\
\hline$\stackrel{\mathscr{0}}{\underline{\Xi}}$ & 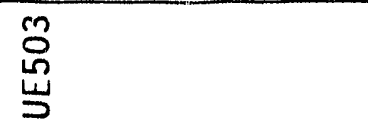 & $\begin{array}{l}\text { m } \\
\text { 怘 } \\
\text { 岁 }\end{array}$ & $\begin{array}{l}\text { 号 } \\
\text { 吕 }\end{array}$ & $\begin{array}{l}\text { 号 } \\
\text { 岂 }\end{array}$ & $\begin{array}{l}\text { m } \\
\text { 足 } \\
\text { 岁 }\end{array}$ & $\begin{array}{l}\text { m } \\
\text { 足 } \\
\text { 岁 }\end{array}$ & $\begin{array}{l}\text { m } \\
\text { 怘 } \\
\text { 崩 }\end{array}$ \\
\hline 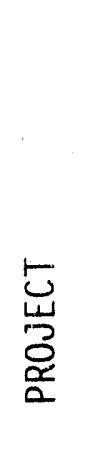 & 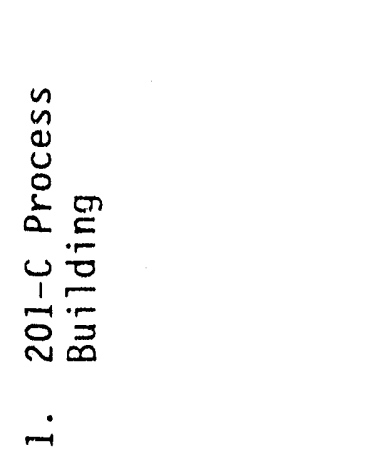 & 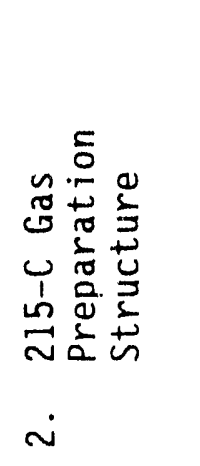 & 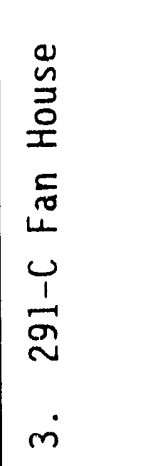 & 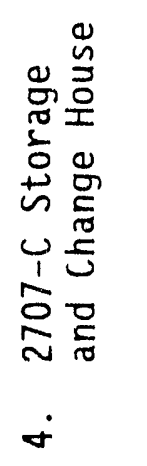 & 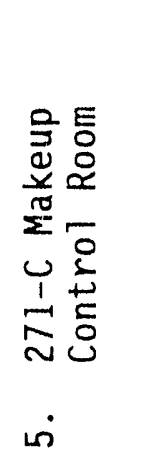 & 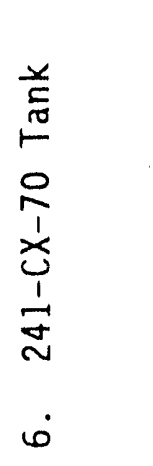 & 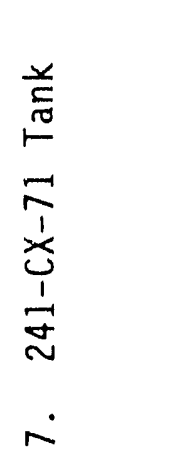 \\
\hline
\end{tabular}


WHC-EP-0231-3

A.5 200 AREA MAJOR PROCESSING/SUPPORT BUILDINGS. (sheet 2 of 9)

\begin{tabular}{|c|c|c|c|c|c|c|c|}
\hline 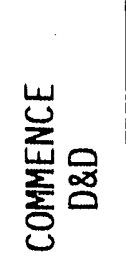 & 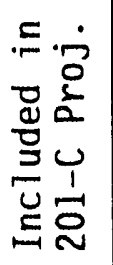 & 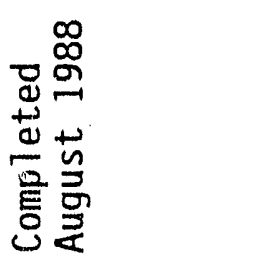 & 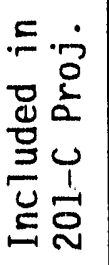 & $\begin{array}{l}\text { ૂ̆ } \\
\text { 乙ે }\end{array}$ & 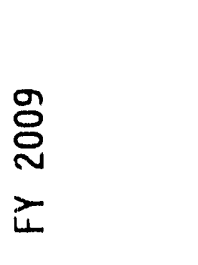 & $\begin{array}{l}\text { Oे } \\
\text { ㅇ } \\
\text { ż }\end{array}$ & 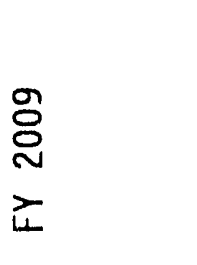 \\
\hline 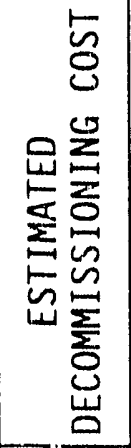 & 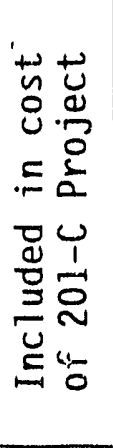 & 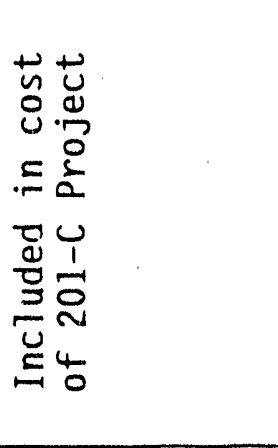 & 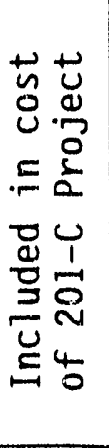 & $\begin{array}{l}8 \\
0 \\
0 \\
0 \\
0 \\
= \\
= \\
n\end{array}$ & $\begin{array}{l}8 \\
0 \\
0 \\
0 \\
0 \\
0 \\
-1 \\
-1\end{array}$ & $\begin{array}{l}8 \\
8 \\
0 \\
0 \\
0 \\
-1 \\
n\end{array}$ & $\begin{array}{l}8 \\
8 \\
\dot{0} \\
0 \\
- \\
-1\end{array}$ \\
\hline 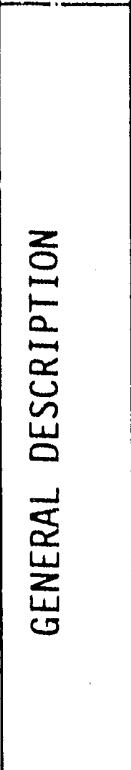 & 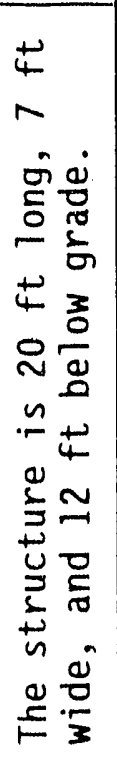 & 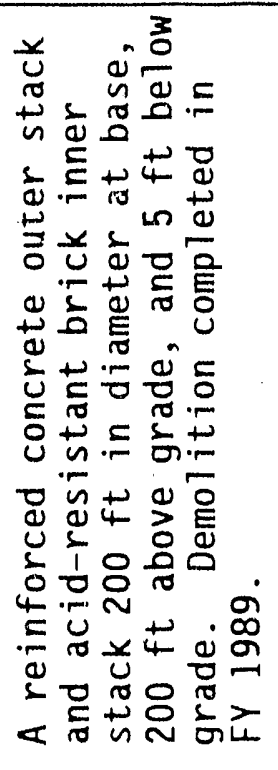 & 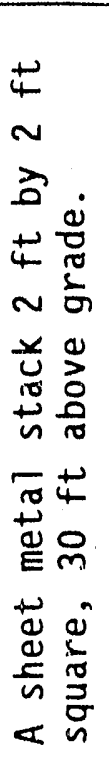 & 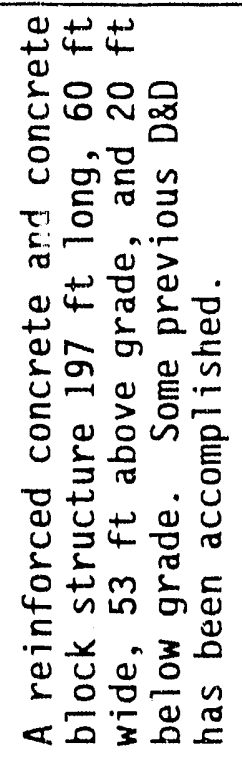 & 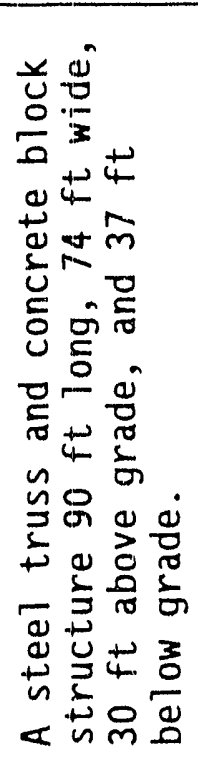 & 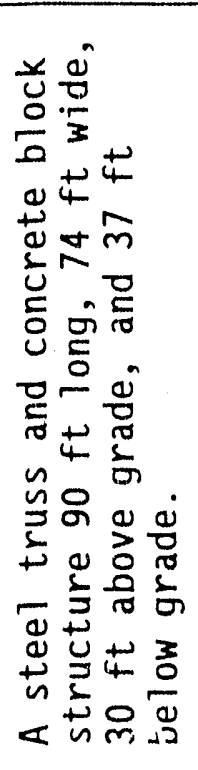 & 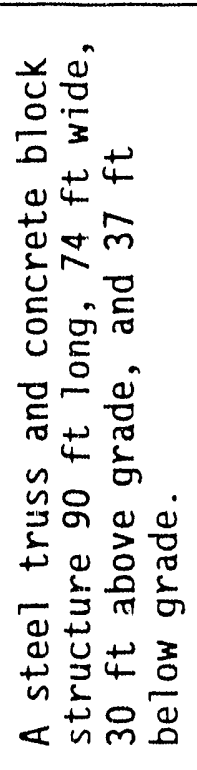 \\
\hline 脬 & $\begin{array}{l}\text { 总 } \\
\text { 㟔 }\end{array}$ & 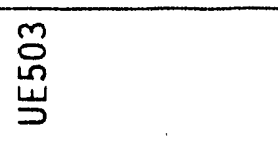 & $\begin{array}{l}\text { m } \\
\text { 吕 } \\
\text { 岁 }\end{array}$ & $\begin{array}{l}\text { 吕 } \\
\text { 岃 }\end{array}$ & 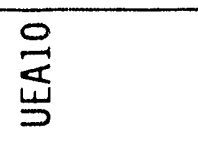 & 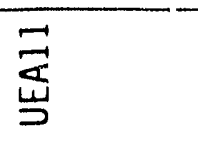 & $\underset{\text { 岌 }}{\beth}$ \\
\hline 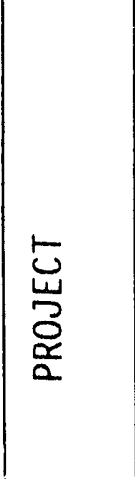 & 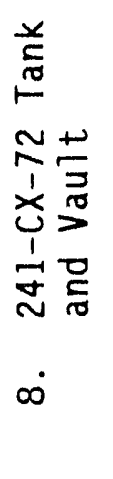 & 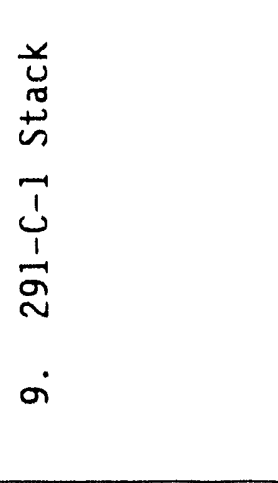 & 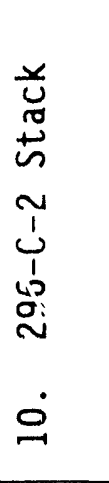 & 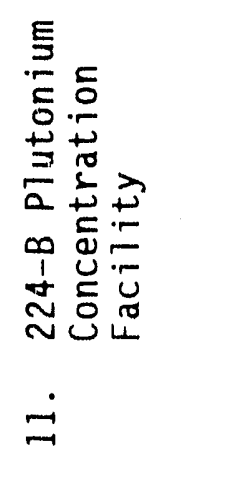 & 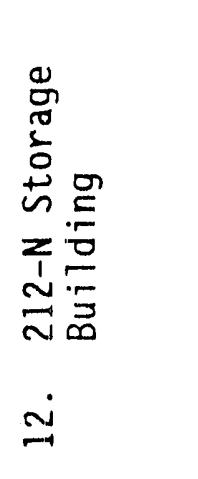 & 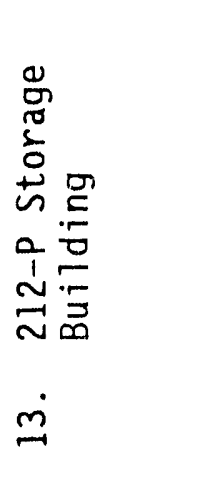 & 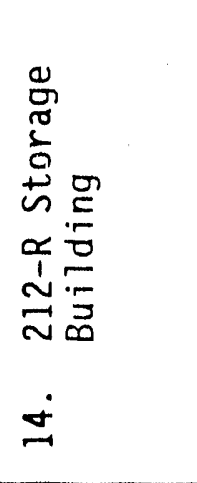 \\
\hline
\end{tabular}


A.5 200 AREA MAJOR PROCESSING/SUPPORT BUILDINGS. (sheet 3 of 9)

\begin{tabular}{|c|c|c|c|c|c|c|c|}
\hline 崖 & $\begin{array}{l}\text { Оू } \\
\text { 乙े }\end{array}$ & 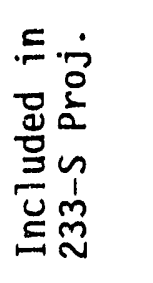 & 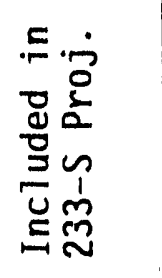 & $\begin{array}{l}\text { जे } \\
\text { N } \\
\text { zे }\end{array}$ & $\begin{array}{l}\overline{\text { Dे }} \\
\text { ż }\end{array}$ & $\begin{array}{l}\text { oे } \\
\text { i } \\
\text { tे }\end{array}$ & 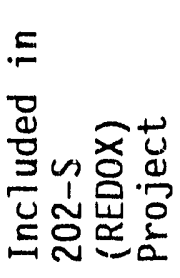 \\
\hline 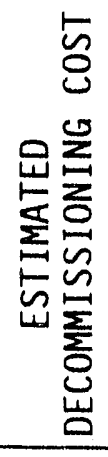 & $\begin{array}{l}8 \\
0 \\
o \\
\stackrel{0}{m} \\
m \\
m \\
m\end{array}$ & 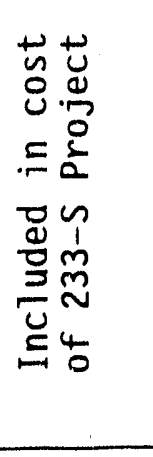 & 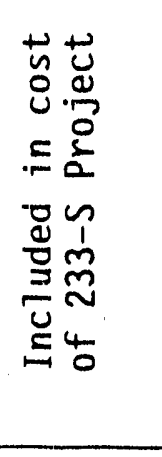 & 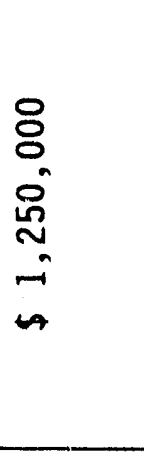 & 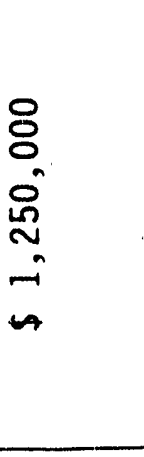 & $\begin{array}{l}8 \\
8 \\
8 \\
8 \\
\infty \\
\stackrel{n}{m} \\
\stackrel{-}{\infty}\end{array}$ & 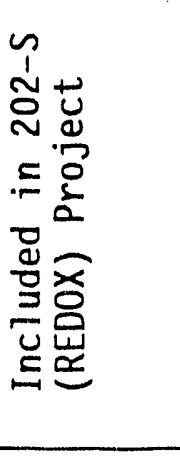 \\
\hline 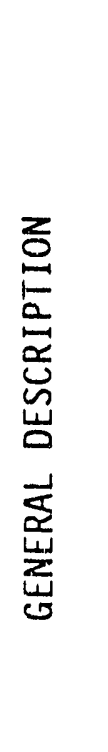 & 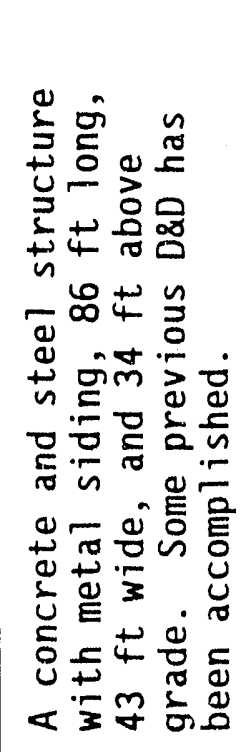 & 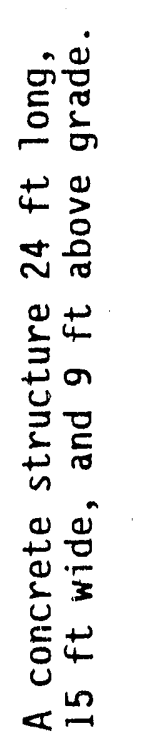 & 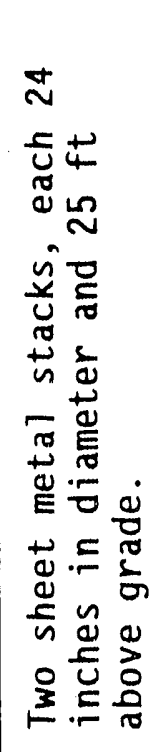 & 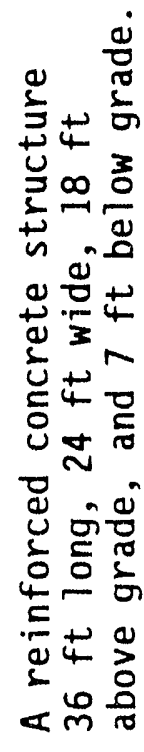 & 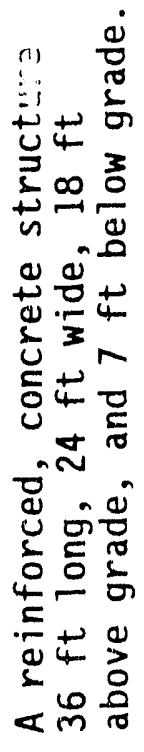 & 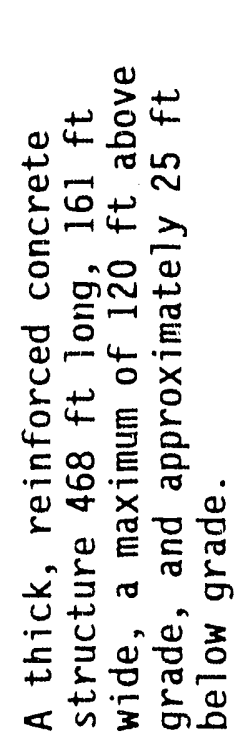 & 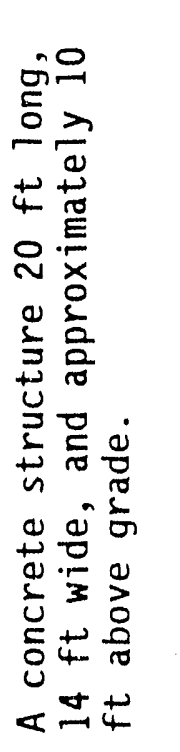 \\
\hline 岕 & $\begin{array}{l}\tilde{D} \\
\text { 号 } \\
\text { 岁 }\end{array}$ & $\begin{array}{l}\widetilde{O} \\
\text { 岃 }\end{array}$ & 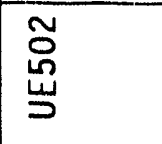 & $\begin{array}{l}\vec{S} \\
\text { 岁 }\end{array}$ & $\begin{array}{l}\text { Oे } \\
\stackrel{+}{J}\end{array}$ & $\begin{array}{l}\vec{\circ} \\
\text { 岁 }\end{array}$ & $\begin{array}{l}\text { 宮 } \\
\stackrel{\leftrightarrow}{\supset}\end{array}$ \\
\hline $\begin{array}{l}\bar{u} \\
\text { 岁 } \\
\text { \& }\end{array}$ & 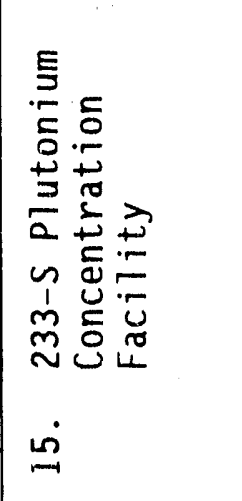 & 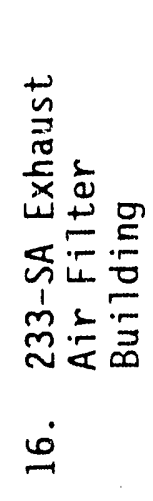 & 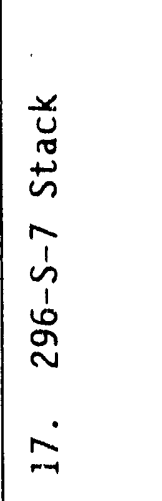 & 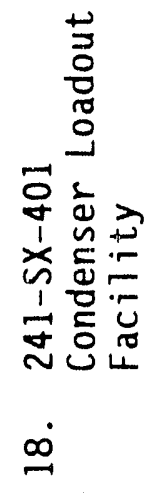 & 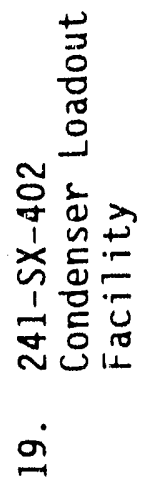 & 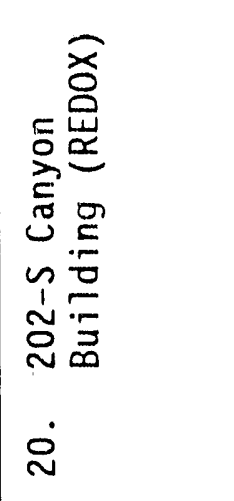 & 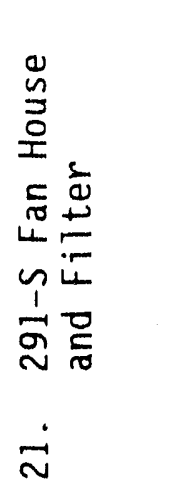 \\
\hline
\end{tabular}


A.5 200 AREA MAJOR PROCESSING/SUPPORT BUILDINGS. (sheet 4 of 9)

\begin{tabular}{|c|c|c|c|c|c|c|c|}
\hline 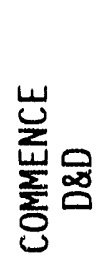 & 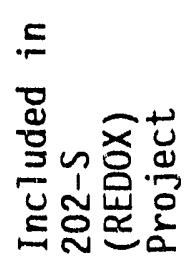 & 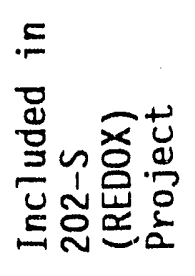 & 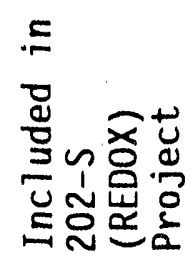 & 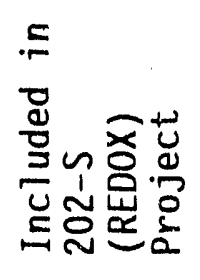 & 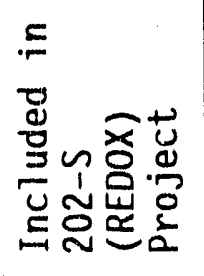 & 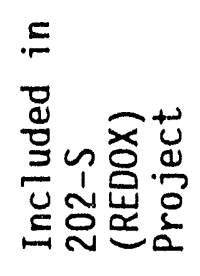 & 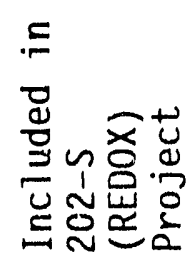 \\
\hline 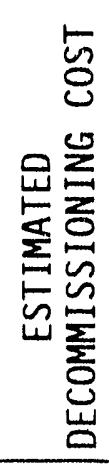 & 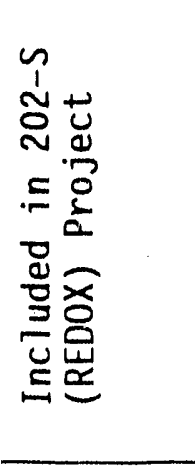 & 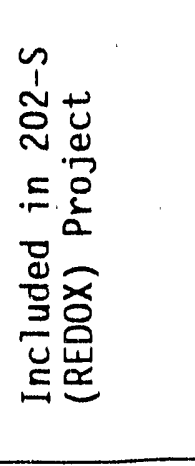 & 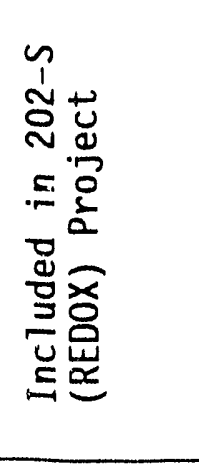 & 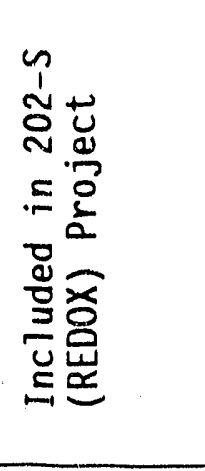 & 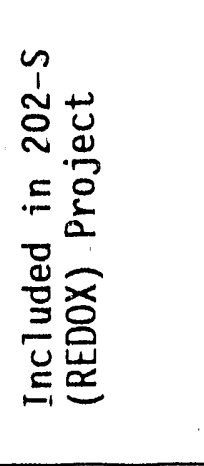 & 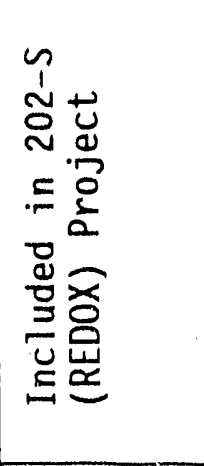 & 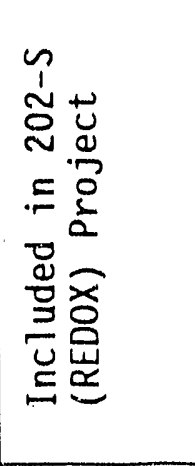 \\
\hline 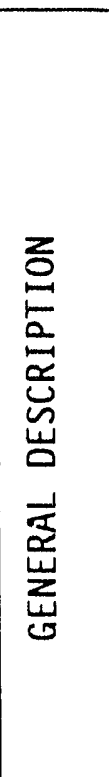 & 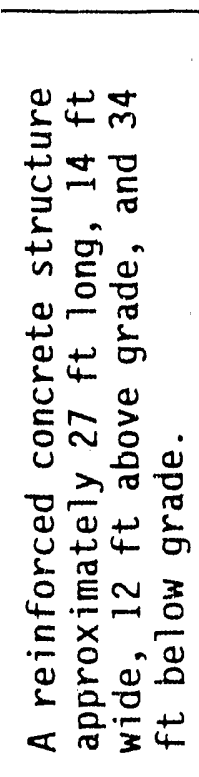 & 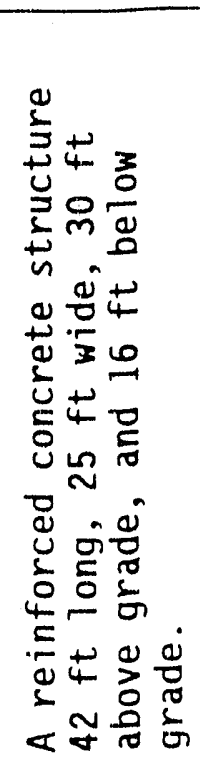 & 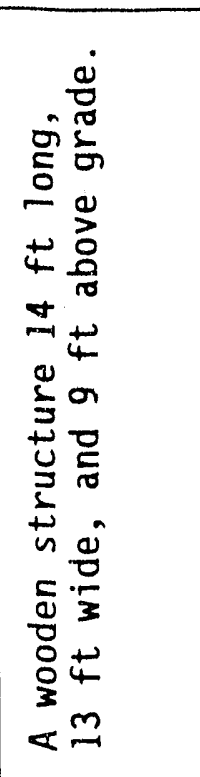 & 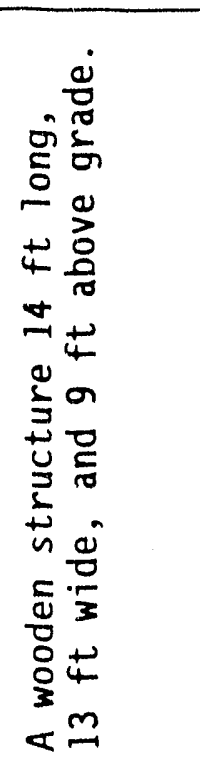 & 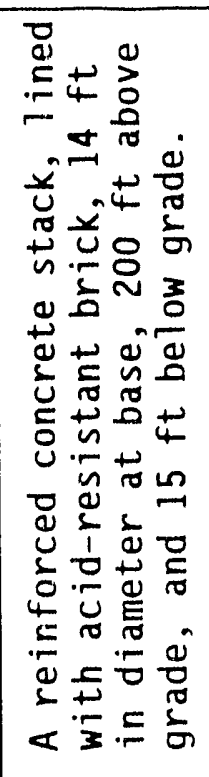 & 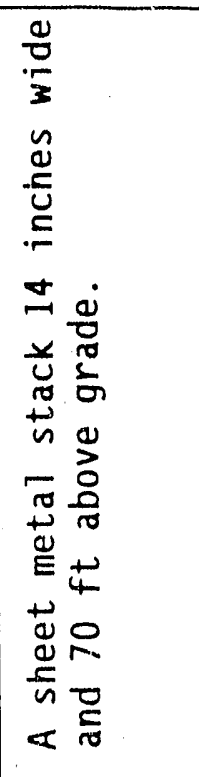 & 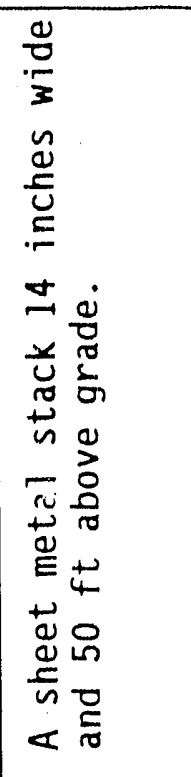 \\
\hline$\tilde{\mathscr{m}}$ & 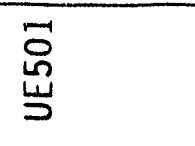 & $\begin{array}{l}\vec{\circ} \\
\stackrel{0}{J} \\
\end{array}$ & $\begin{array}{l}\overline{5} \\
\stackrel{0}{د}\end{array}$ & $\begin{array}{l}\overrightarrow{0} \\
\stackrel{5}{J}\end{array}$ & 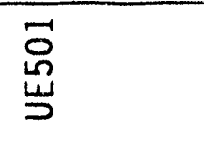 & 总 & $\begin{array}{l}\overrightarrow{0} \\
\text { 号 } \\
\end{array}$ \\
\hline 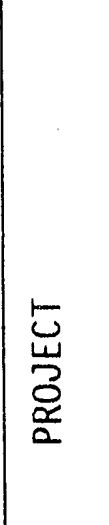 & 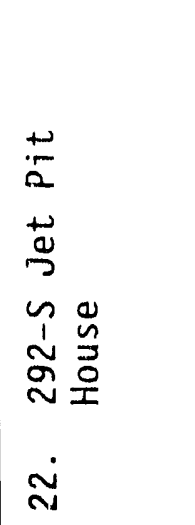 & 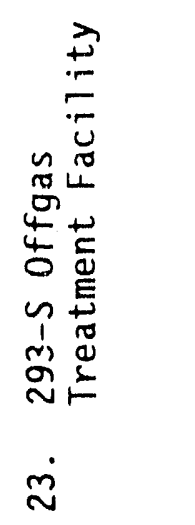 & 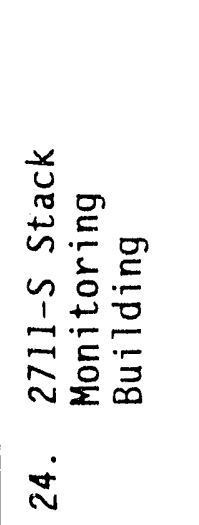 & 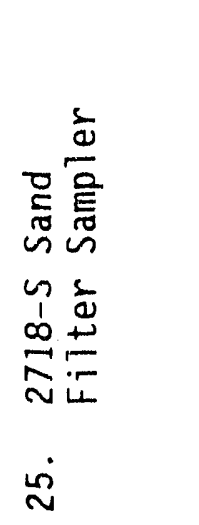 & 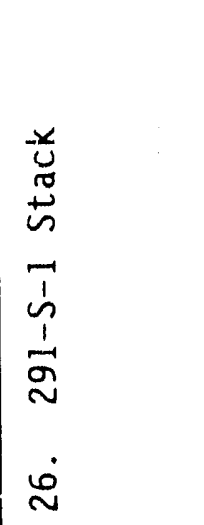 & 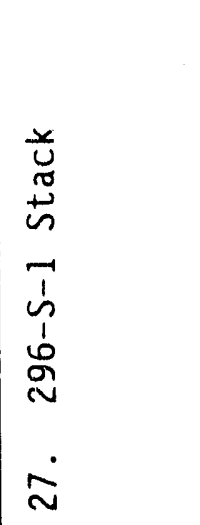 & 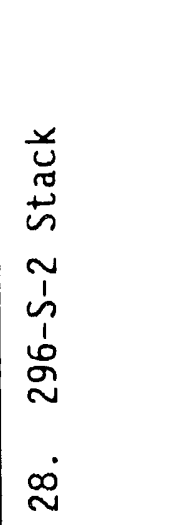 \\
\hline
\end{tabular}


A.5 200 AREA MAJOR PROCESSING/SUPPORT BUILDINGS. (sheet 5 of 9)

\begin{tabular}{|c|c|c|c|c|c|c|c|}
\hline 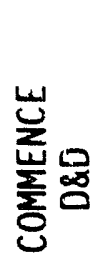 & 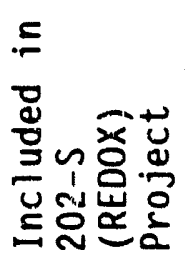 & 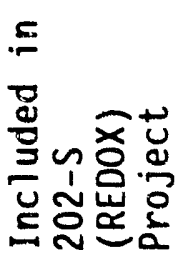 & $\begin{array}{l}\text { gू } \\
\frac{1}{2}\end{array}$ & 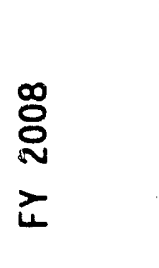 & 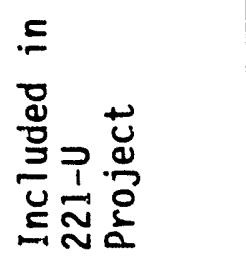 & 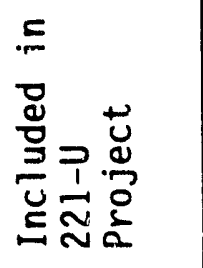 & 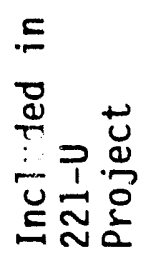 \\
\hline 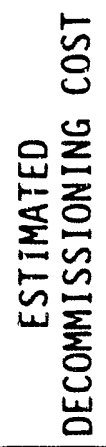 & 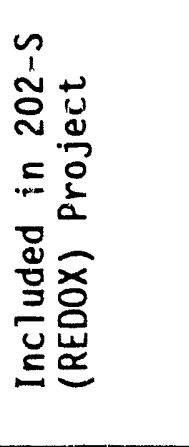 & 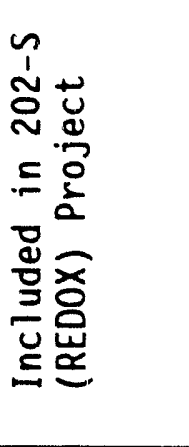 & $\begin{array}{l}8 \\
8 \\
0 \\
0 \\
\infty\end{array}$ & 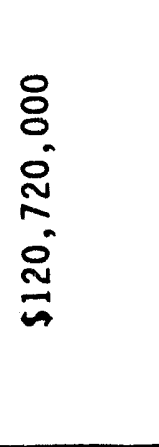 & 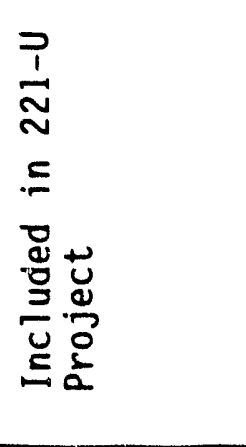 & 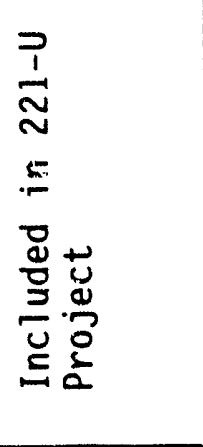 & 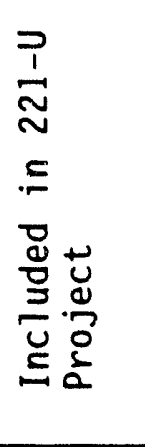 \\
\hline 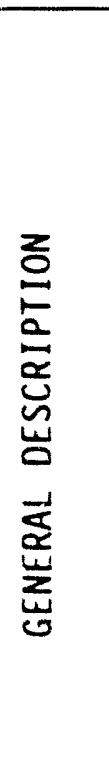 & 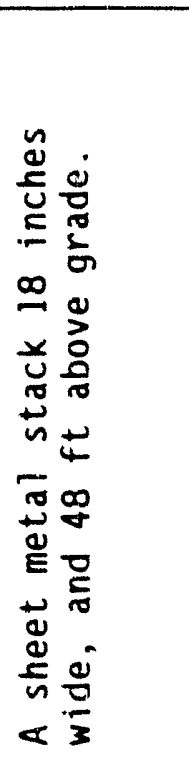 & 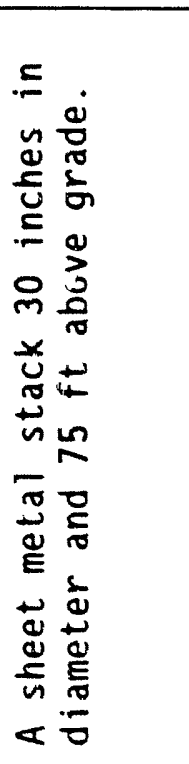 & 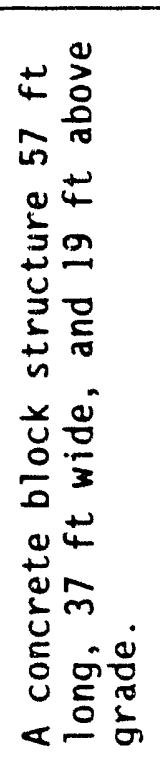 & 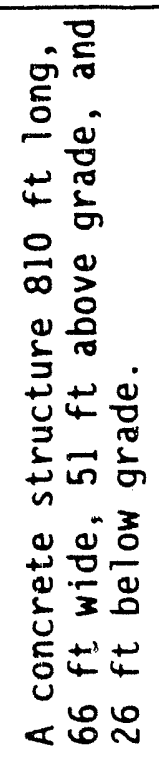 & 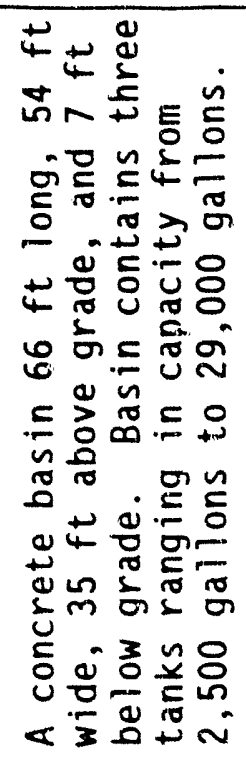 & 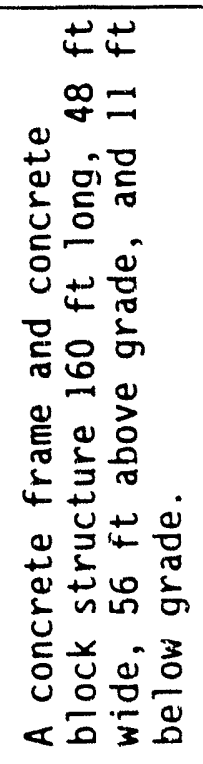 & 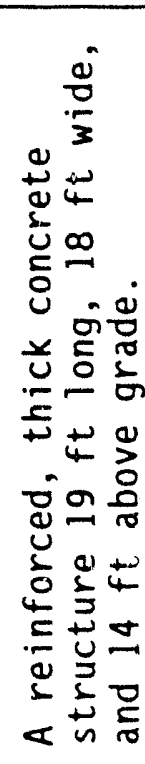 \\
\hline$\cong$ & 宫 & 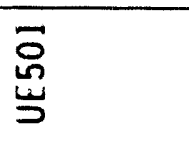 & $\begin{array}{l} \\
\\
\end{array}$ & 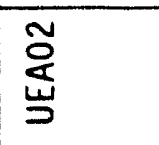 & 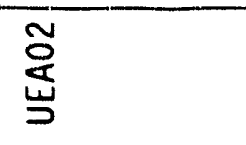 & 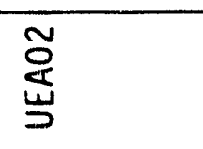 & 茟 \\
\hline 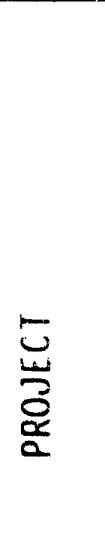 & 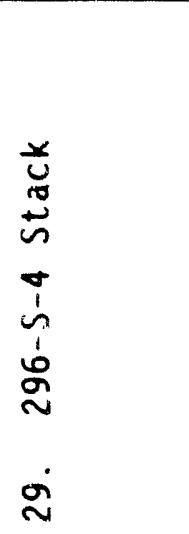 & 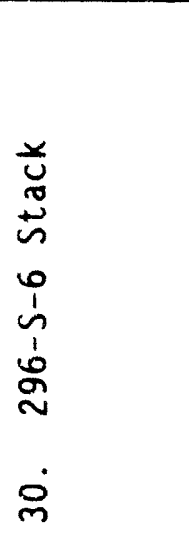 & 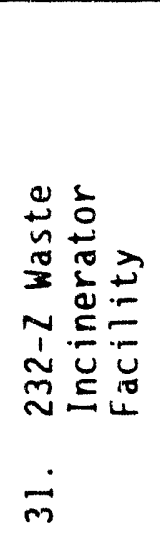 & 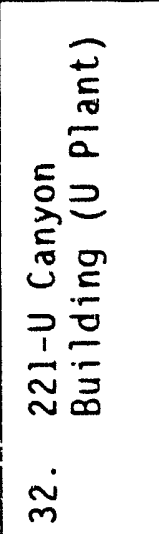 & 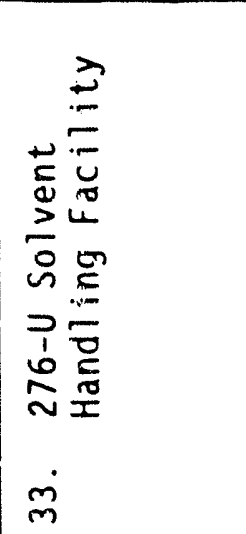 & 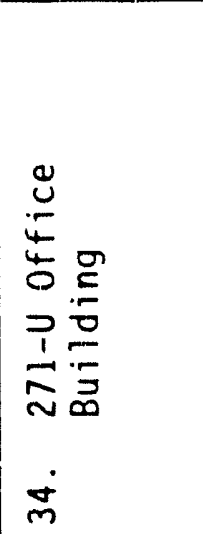 & 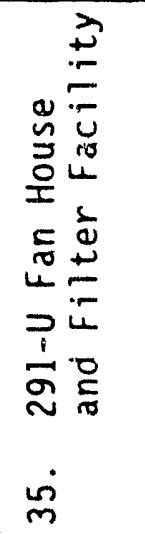 \\
\hline
\end{tabular}


A.5 200 AREA MAJOR PROCESSING/SUPPORT BUILDINGS. (sheet 6 of 9)

\begin{tabular}{|c|c|c|c|c|c|c|c|c|}
\hline 岁 & 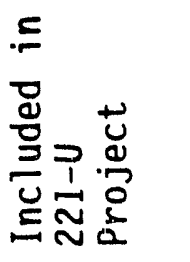 & 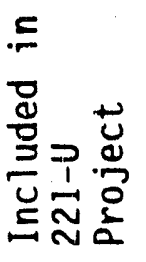 & 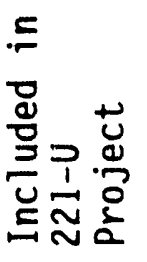 & $\begin{array}{l}\stackrel{9}{0} \\
\text { 은 } \\
7\end{array}$ & $\begin{array}{l}\text { gू } \\
\text { ऽ } \\
\frac{1}{4}\end{array}$ & 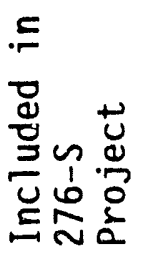 & 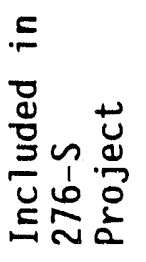 & 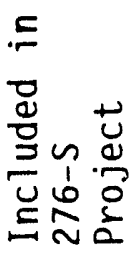 \\
\hline 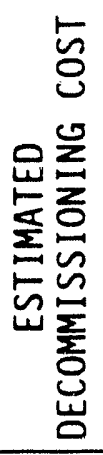 & 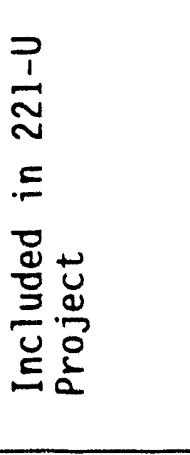 & 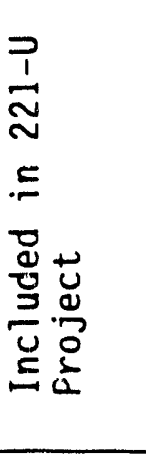 & 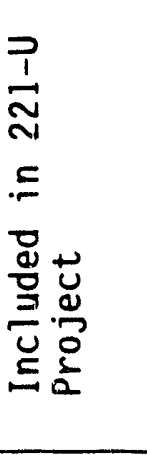 & $\begin{array}{l}8 \\
8 \\
0 \\
n \\
n \\
n\end{array}$ & $\begin{array}{l}8 \\
8 \\
\infty \\
\infty \\
1 \\
n\end{array}$ & 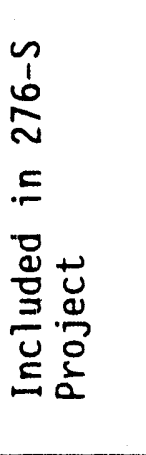 & 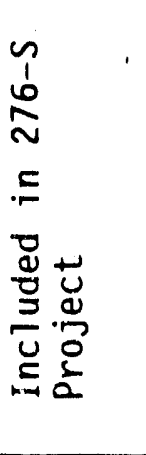 & 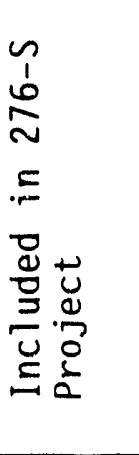 \\
\hline 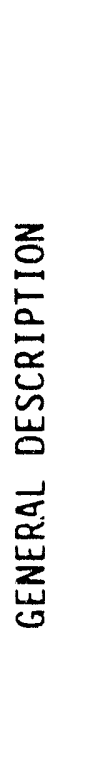 & 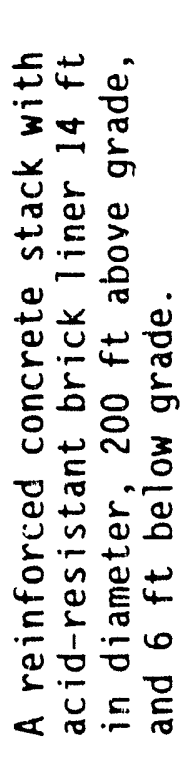 & 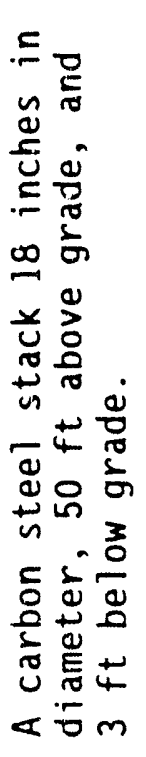 & 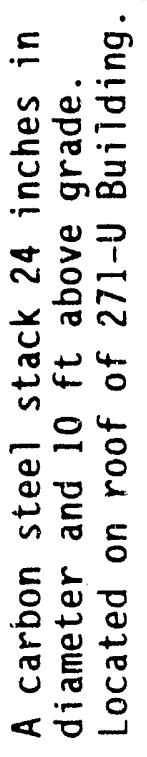 & 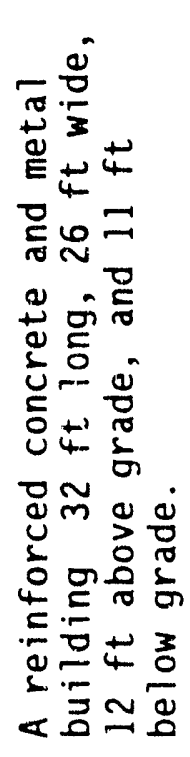 & 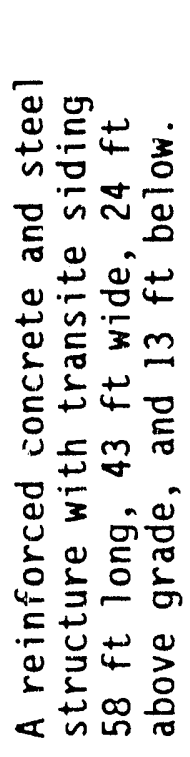 & 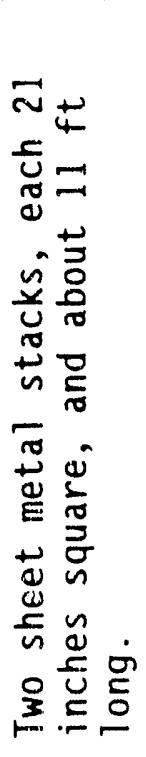 & 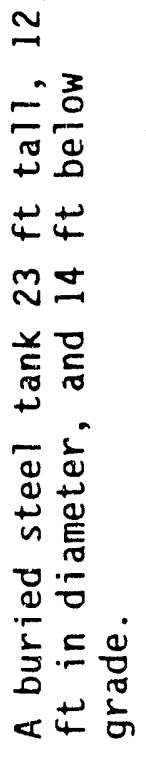 & 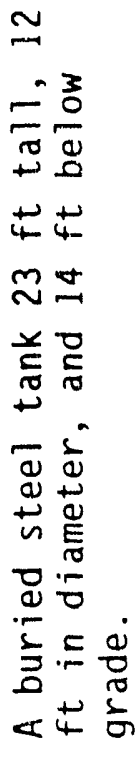 \\
\hline $\begin{array}{l}\mathscr{\cong} \\
\stackrel{\mathscr{N}}{\mathbf{n}}\end{array}$ & 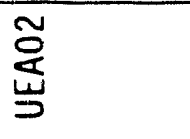 & 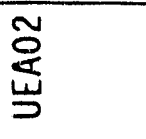 & 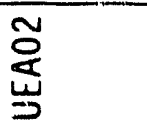 & 总 & 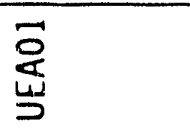 & 定 & $\begin{array}{l}\vec{\Phi} \\
\stackrel{\underline{J}}{J}\end{array}$ & 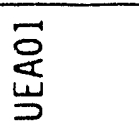 \\
\hline 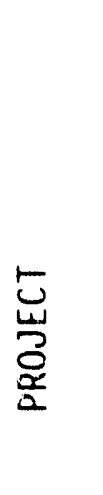 & 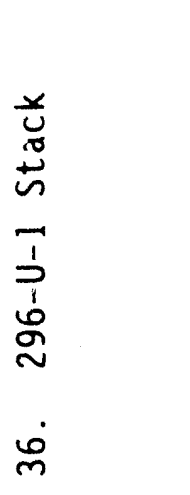 & 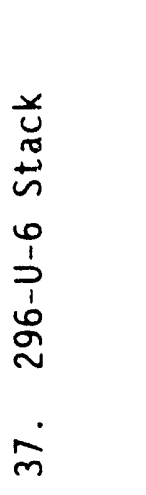 & 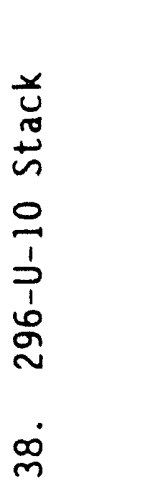 & 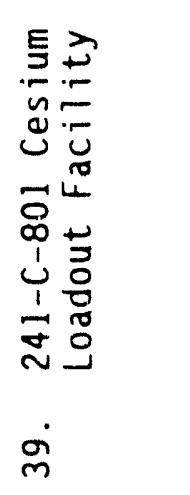 & 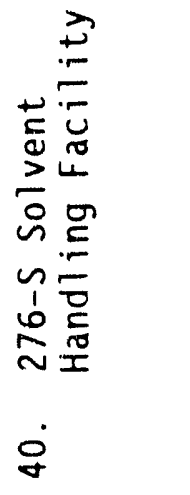 & 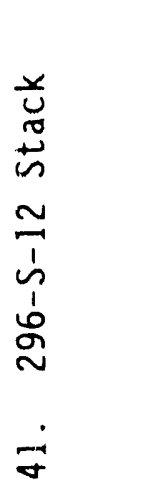 & 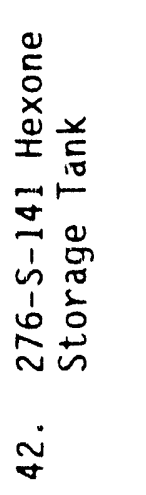 & 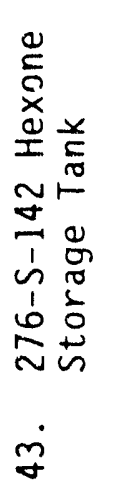 \\
\hline
\end{tabular}


WHC-EP-0231-3

A.5 200 AREA MAJOR PROCESSING/SUPPORT BUILDINGS. (sheet 7 of 9)

\begin{tabular}{|c|c|c|c|c|c|}
\hline 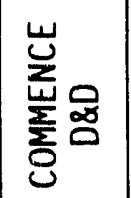 & $\begin{array}{l}\infty \\
\stackrel{\infty}{\circ} \\
亡\end{array}$ & $\begin{array}{l}\infty \\
\stackrel{\sim}{2} \\
\grave{L}\end{array}$ & $\begin{array}{l}\infty \\
0 \\
0 \\
亡 \\
亡\end{array}$ & $\begin{array}{l}\text { 음 } \\
\text { } \\
\frac{2}{4}\end{array}$ & 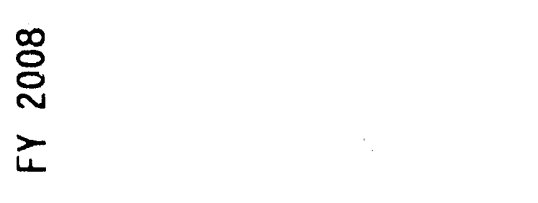 \\
\hline 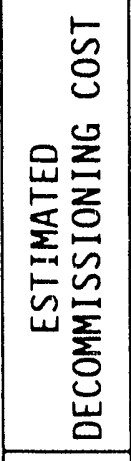 & 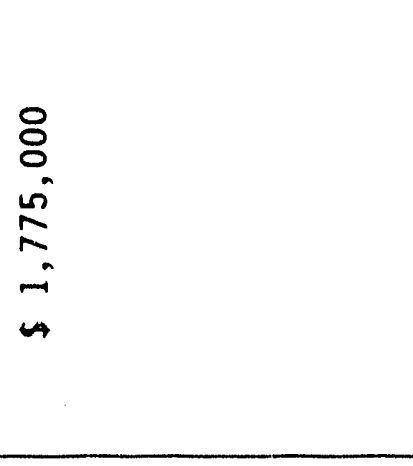 & $\begin{array}{l}8 \\
8 \\
\text { in } \\
n\end{array}$ & $\begin{array}{l}\stackrel{8}{8} \\
\stackrel{\infty}{\pi} \\
\stackrel{\infty}{*} \\
\sim\end{array}$ & 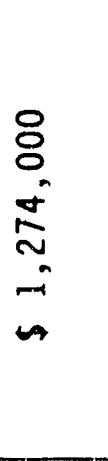 & 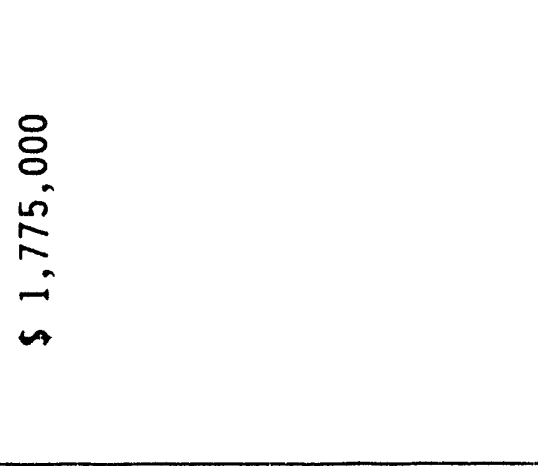 \\
\hline 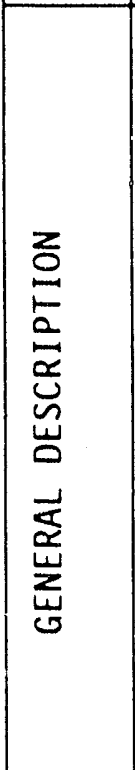 & 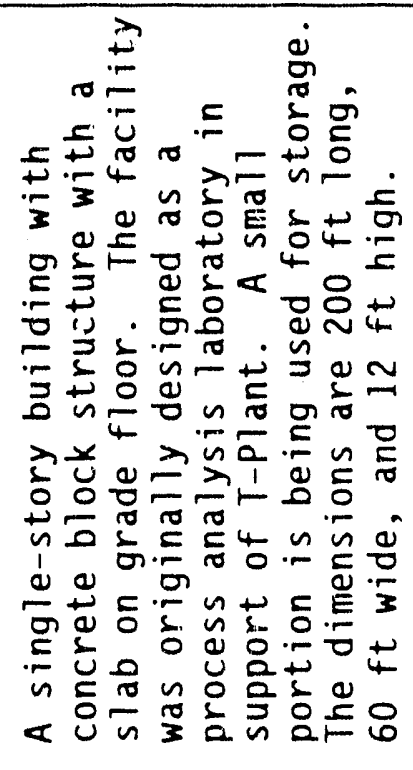 & 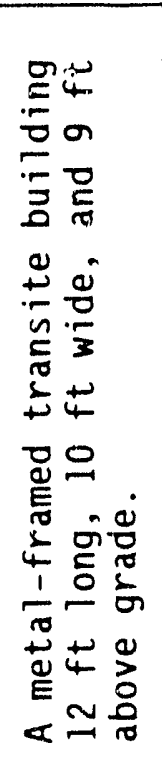 & 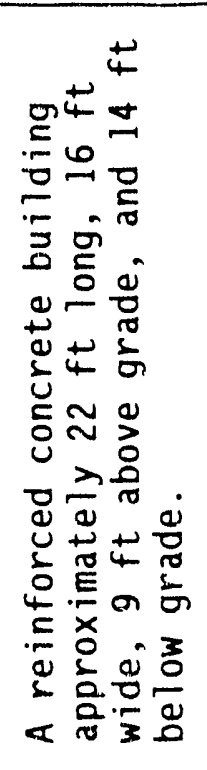 & 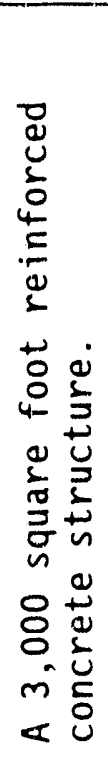 & 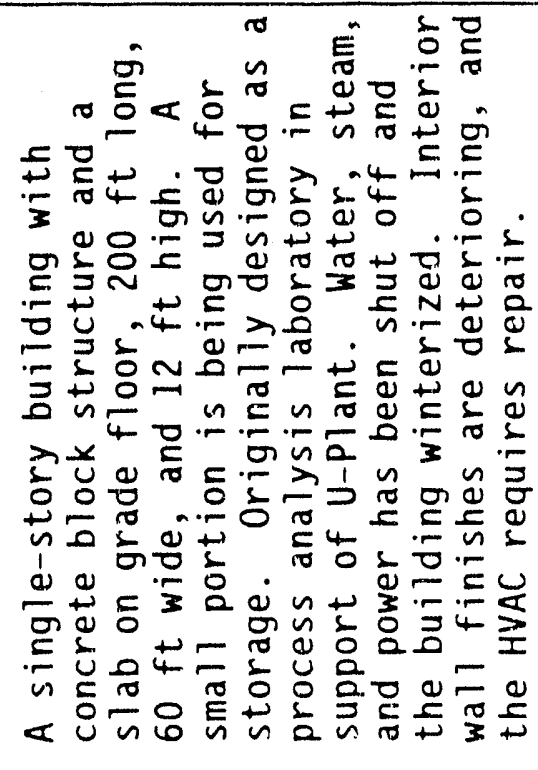 \\
\hline$\tilde{\mathscr{m}}$ & $\begin{array}{l}\overrightarrow{8} \\
\mathbb{8} \\
\text { J }\end{array}$ & 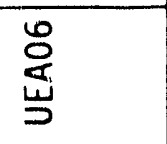 & $\begin{array}{l}\text { 导 } \\
\text { 岁 }\end{array}$ & $\begin{array}{l}\text { 운 } \\
\text { 岁 }\end{array}$ & $\begin{array}{l}\widetilde{\widetilde{O}} \\
\text { 品 }\end{array}$ \\
\hline 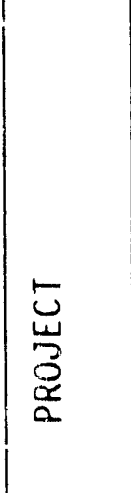 & 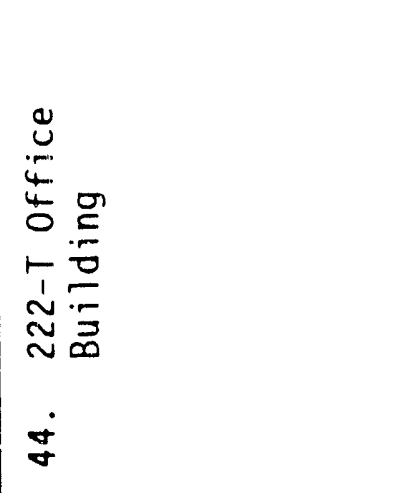 & 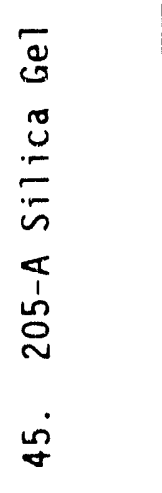 & 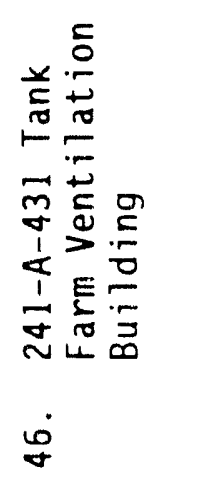 & 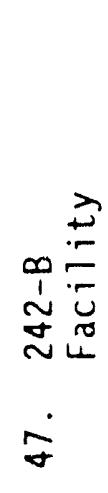 & 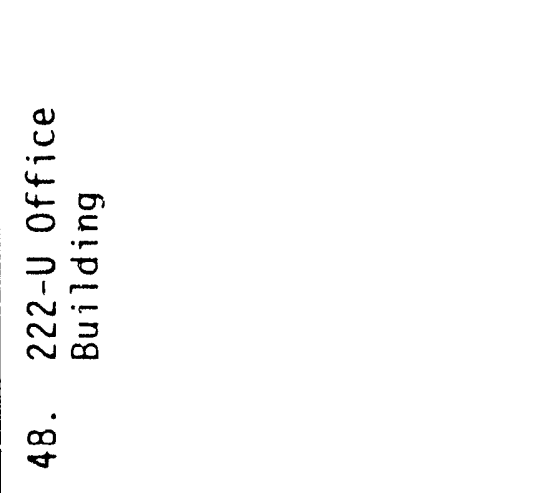 \\
\hline
\end{tabular}


A.5 200 AREA MAJOR PROCESSING/SUPPORT BUILDINGS. (sheet 8 of 9 )

\begin{tabular}{|c|c|c|}
\hline 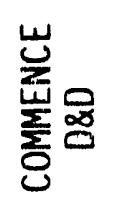 & $\begin{array}{l}\text { gू } \\
\text { g- } \\
\frac{1}{4}\end{array}$ & 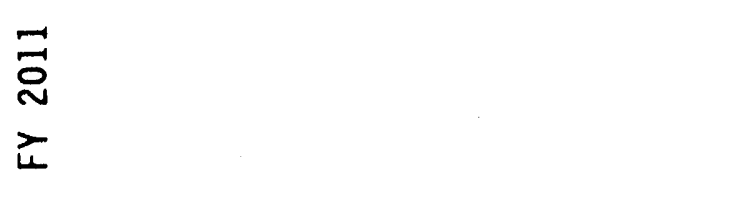 \\
\hline 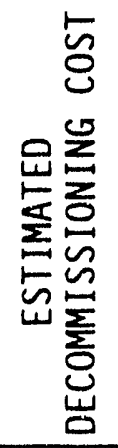 & $\begin{array}{l}8 \\
8 \\
0 \\
\text { on } \\
n\end{array}$ & $\begin{array}{l}8 \\
8 \\
0 \\
\text { مீ } \\
\text { on } \\
\text { - }\end{array}$ \\
\hline 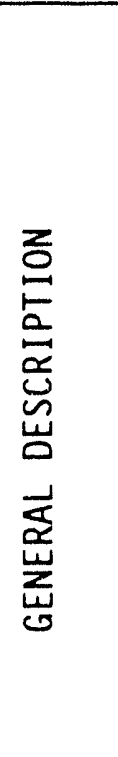 & 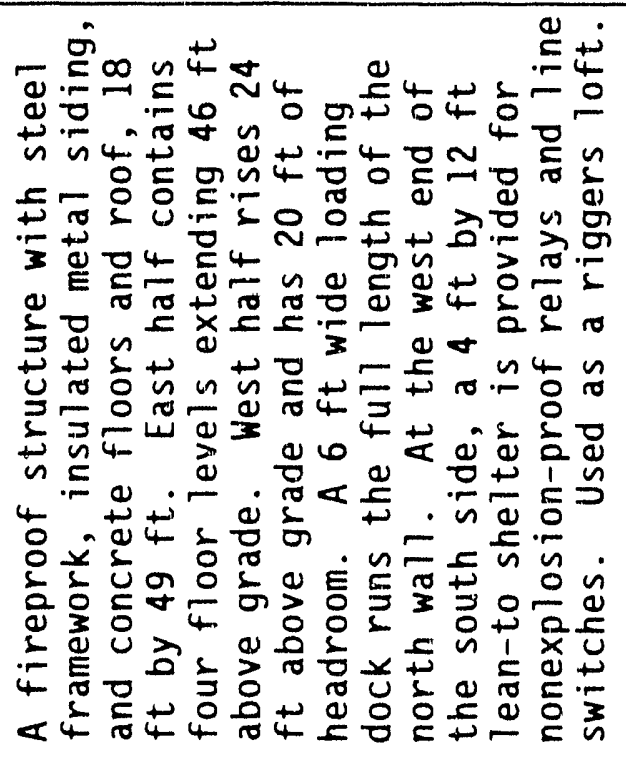 & 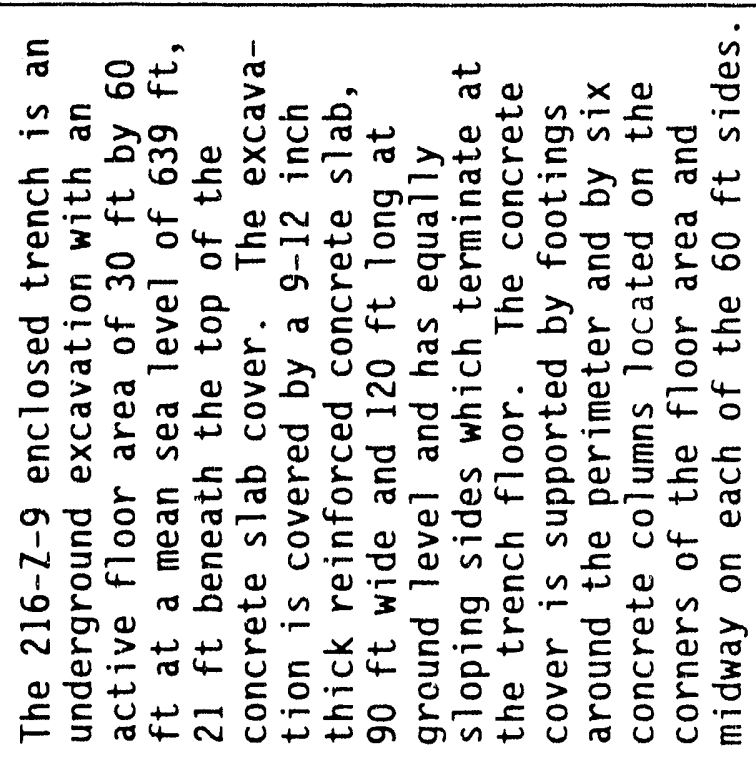 \\
\hline$\stackrel{\mathscr{N}}{3}$ & 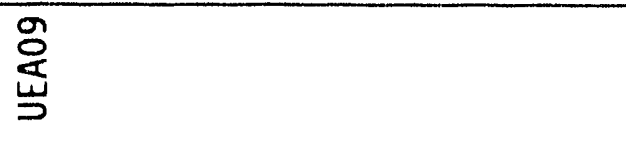 & $\begin{array}{l}\infty \\
\stackrel{0}{⿺} \\
\stackrel{4}{J}\end{array}$ \\
\hline 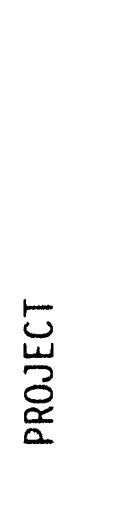 & 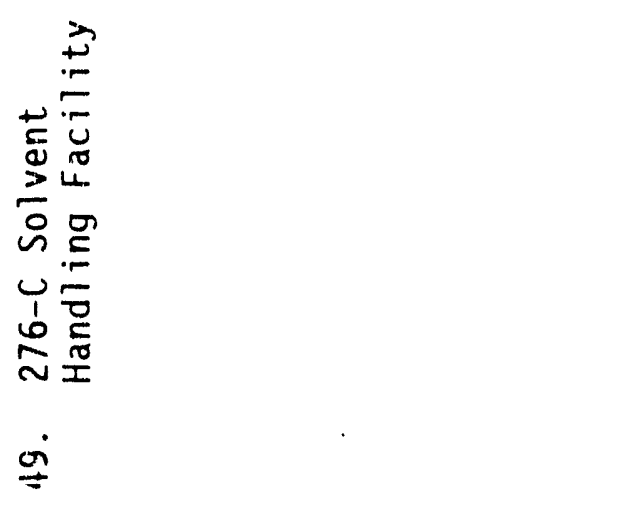 & 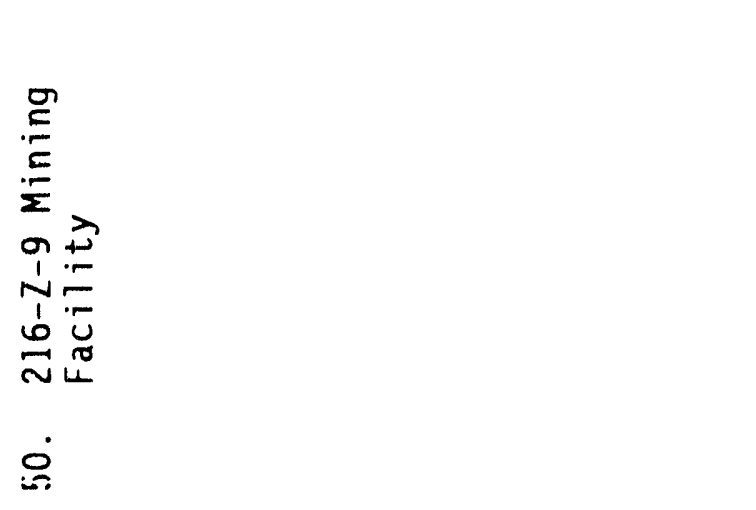 \\
\hline
\end{tabular}


WHC-EP-0231-3

A.5 200 AREA MAJOR PROCESSING/SUPPORT BUILDINGS. (sheet 9 of 9 )

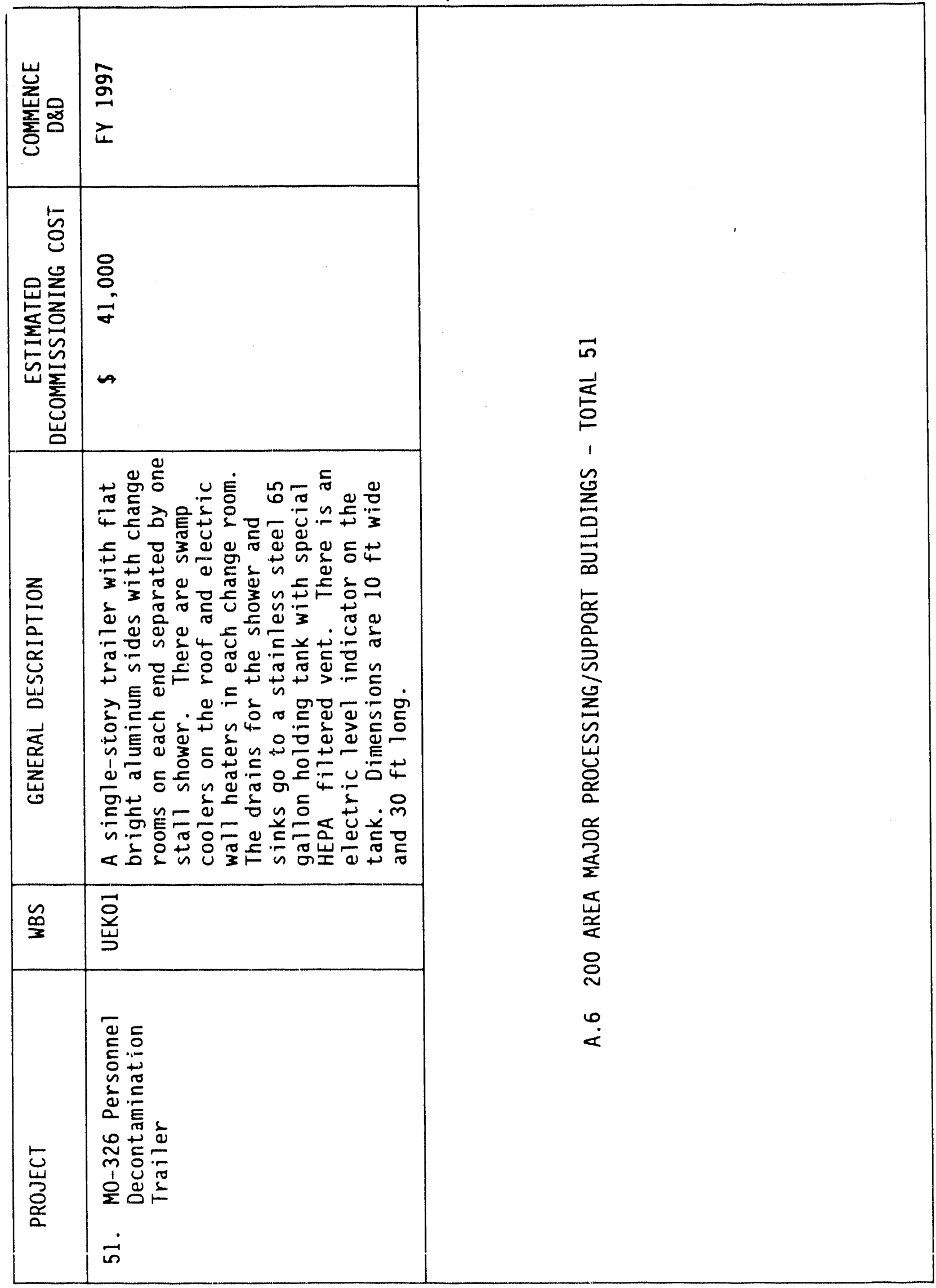


WHC-EP-0231-3

A.6 207-S RETENTION BASIN.

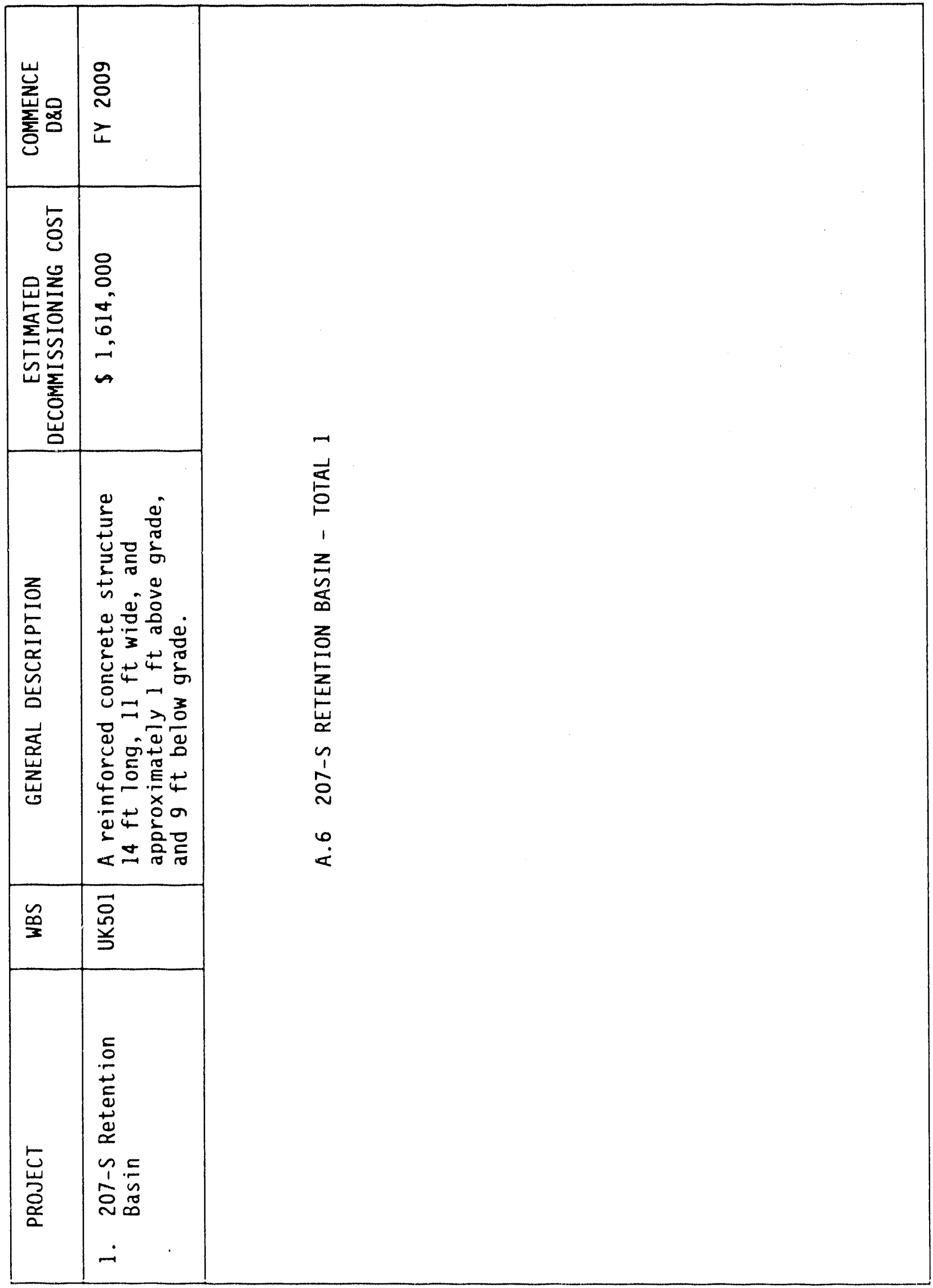


A.7 200 AREA CONTROL STRUCTURES AND WEIR BOXES.

\begin{tabular}{|c|c|c|c|c|c|c|c|}
\hline 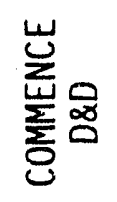 & $\begin{array}{l}\stackrel{0}{0} \\
\text { ํ. } \\
Z\end{array}$ & $\begin{array}{l}\stackrel{0}{0} \\
\text { ․ } \\
亡\end{array}$ & 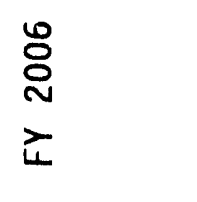 & 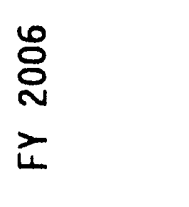 & 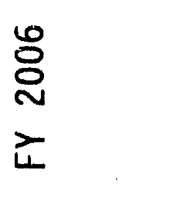 & $\begin{array}{l}\stackrel{0}{0} \\
\stackrel{N}{4} \\
\check{\amalg}\end{array}$ & \\
\hline 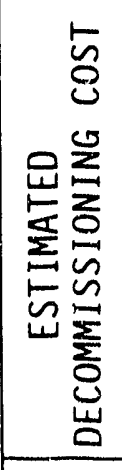 & 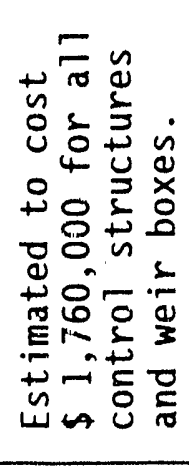 & 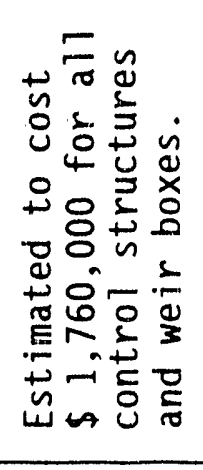 & 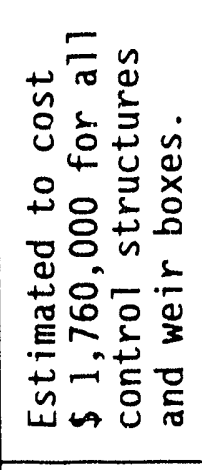 & 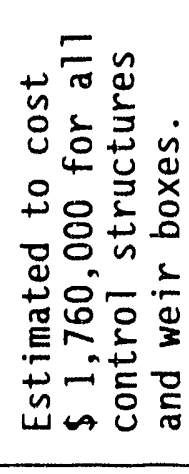 & 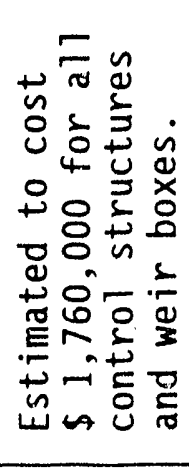 & 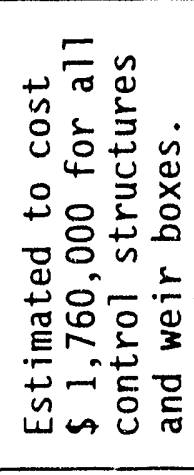 & 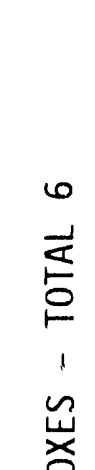 \\
\hline 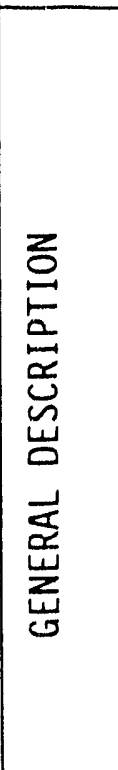 & 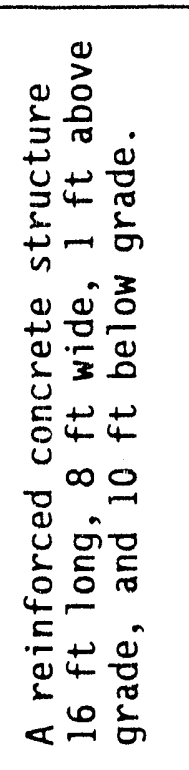 & 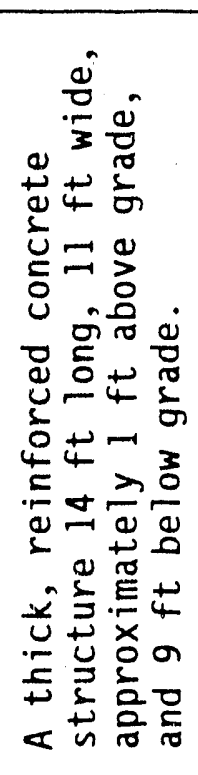 & 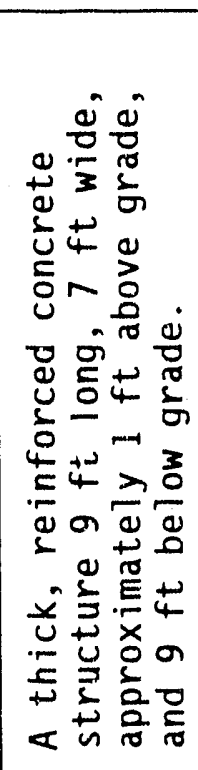 & 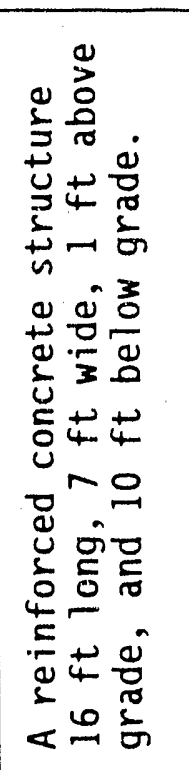 & 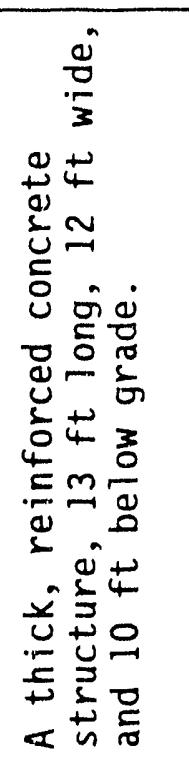 & 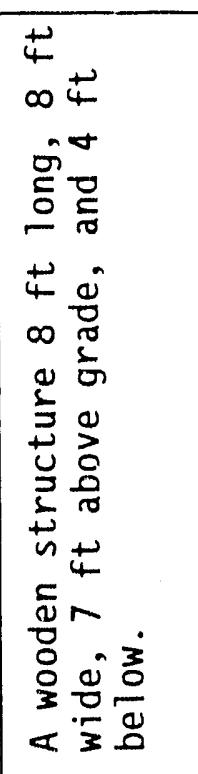 & 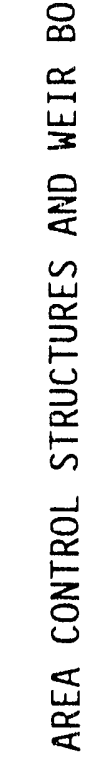 \\
\hline$\tilde{\mathscr{\alpha}}$ & 홍 & $\begin{array}{l}\text { ㅇ } \\
\text { 곻 }\end{array}$ & 誉 & 옴 & $\begin{array}{l}\stackrel{12}{0} \\
\stackrel{7}{5}\end{array}$ & $\begin{array}{l}\stackrel{0}{\circ} \\
\text { 곡 }\end{array}$ & $\begin{array}{l}\stackrel{D}{\sim} \\
\text { r. }\end{array}$ \\
\hline $\begin{array}{l}\text { 崩 } \\
\text { J } \\
\text { \& }\end{array}$ & 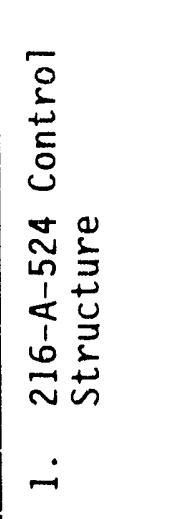 & 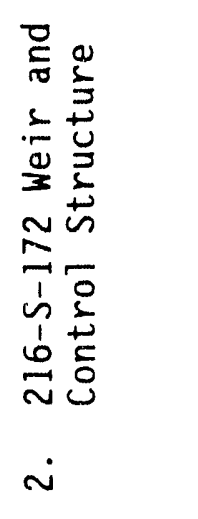 & 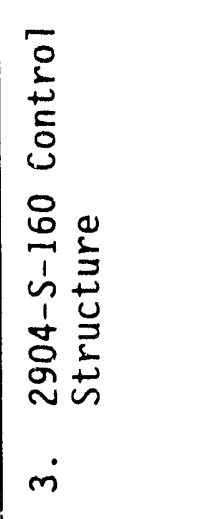 & 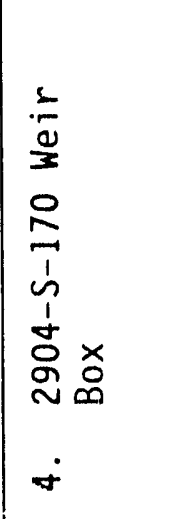 & 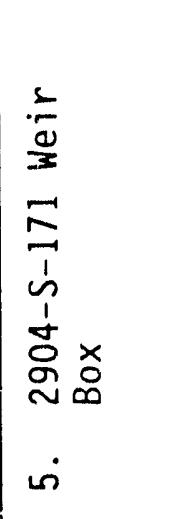 & 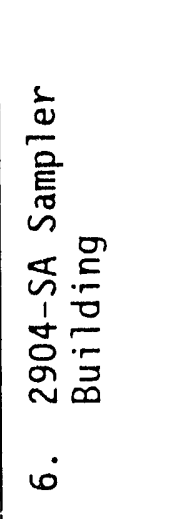 & \\
\hline
\end{tabular}


A.8 200 AREA DIRECT-BURIED TANKS.

\begin{tabular}{|c|c|c|c|c|c|c|}
\hline 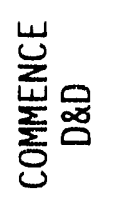 & $\begin{array}{l}\text { g } \\
8 \\
\text { 긴 }\end{array}$ & $\begin{array}{l}\text { O } \\
\text { O } \\
\text { ঠे }\end{array}$ & $\begin{array}{l}\text { g } \\
\text { ㅇ } \\
\text { 눈 }\end{array}$ & $\begin{array}{l}\text { O } \\
\text { D } \\
\text { Z }\end{array}$ & $\begin{array}{l}\text { Oे } \\
\text { 은 } \\
\text { ż }\end{array}$ & \\
\hline 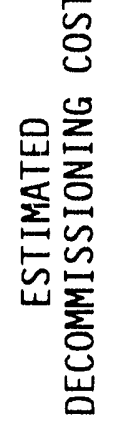 & 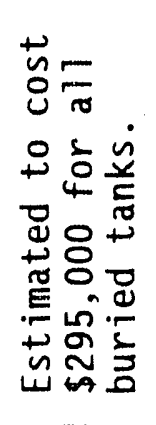 & 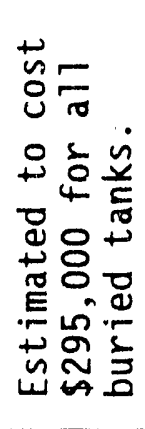 & 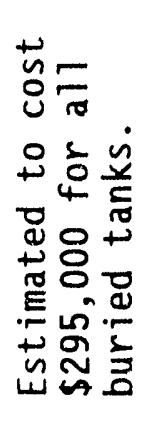 & 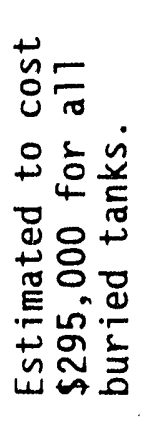 & 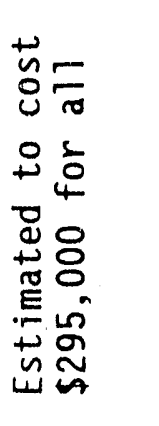 & \\
\hline 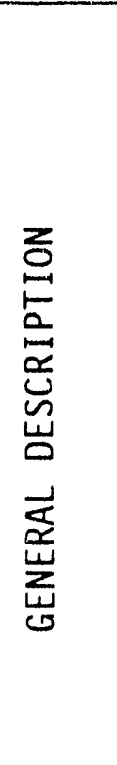 & 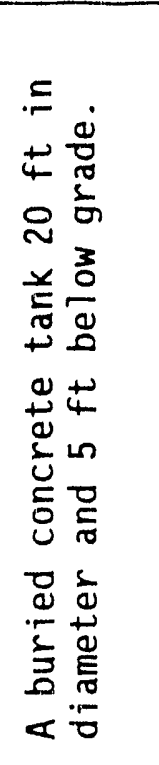 & 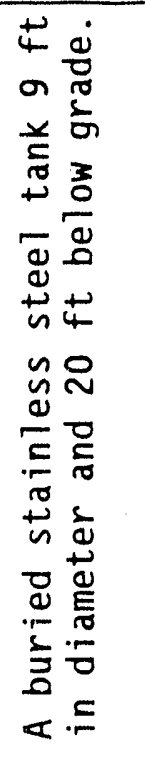 & 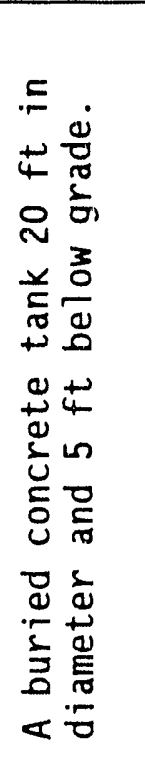 & 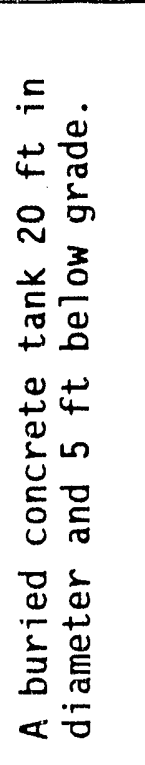 & 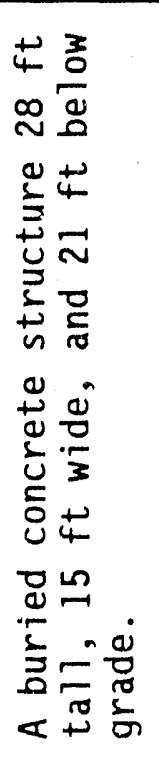 & 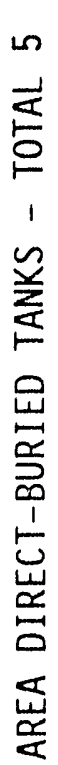 \\
\hline$\stackrel{\mathscr{D}}{\mathscr{Z}}$ & 惡 & 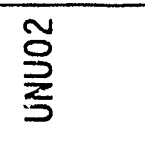 & $\stackrel{\text { m }}{\grave{S}}$ & $\begin{array}{l}\text { む্ } \\
\grave{\zeta}\end{array}$ & $\stackrel{10}{\stackrel{0}{3}}$ & $\begin{array}{l}\text { O } \\
\infty\end{array}$ \\
\hline 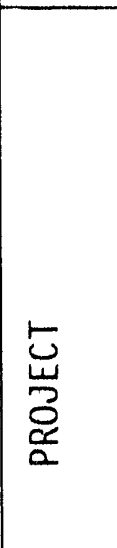 & 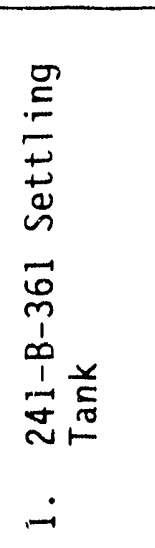 & 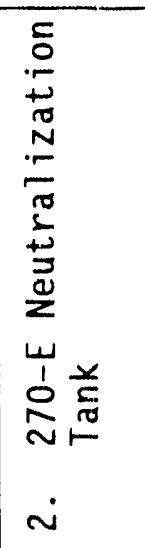 & 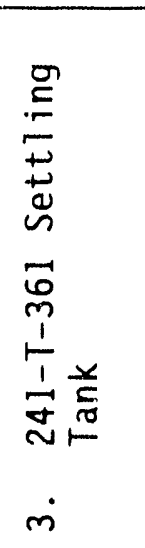 & 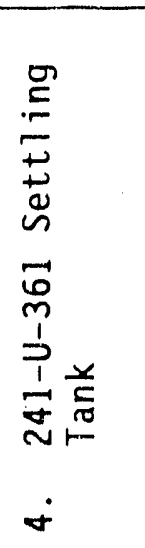 & 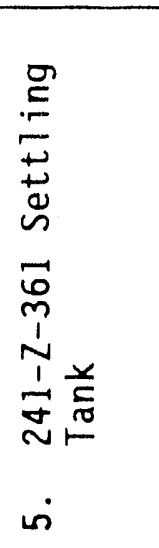 & $\dot{\tau}$ \\
\hline
\end{tabular}


A.9 300 AREA CONTAMINATED FACILITIES. (sheet 1 of 2)

\begin{tabular}{|c|c|c|}
\hline 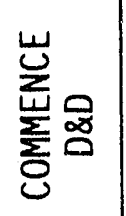 & $\begin{array}{l}\text { જे } \\
\text { ఫ } \\
\text { خ }\end{array}$ & 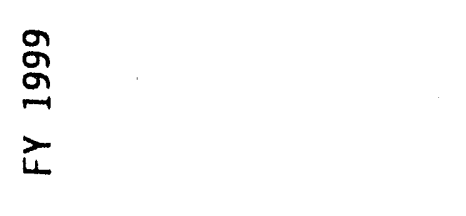 \\
\hline 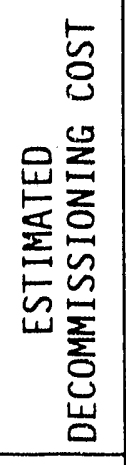 & 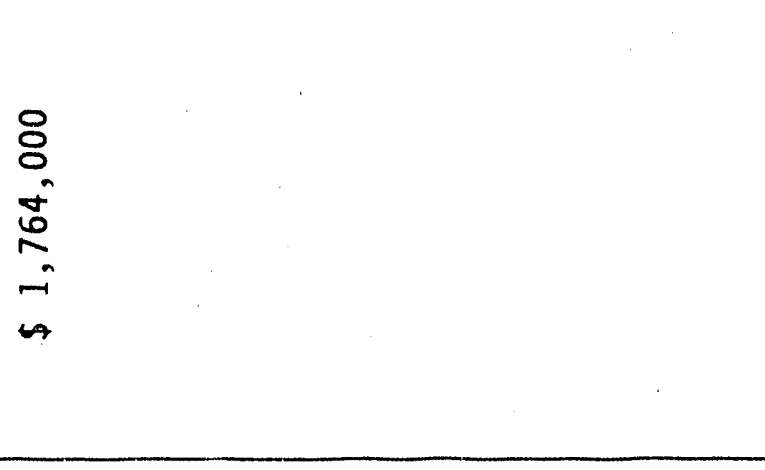 & $\begin{array}{l}8 \\
8 \\
\infty \\
\infty \\
0 \\
\sim \\
\sim \\
n \\
n\end{array}$ \\
\hline 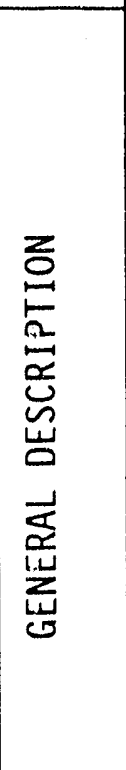 & 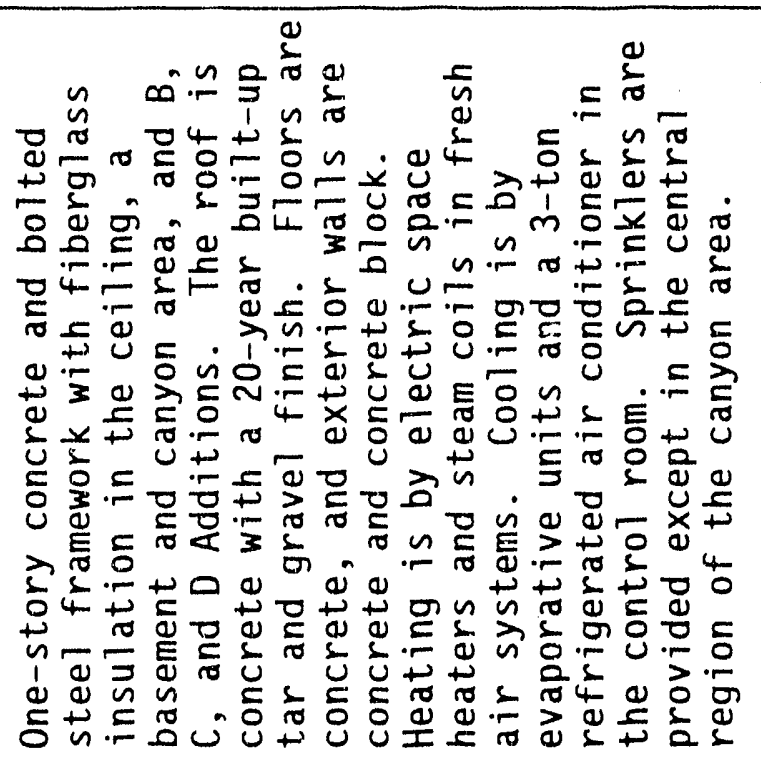 & 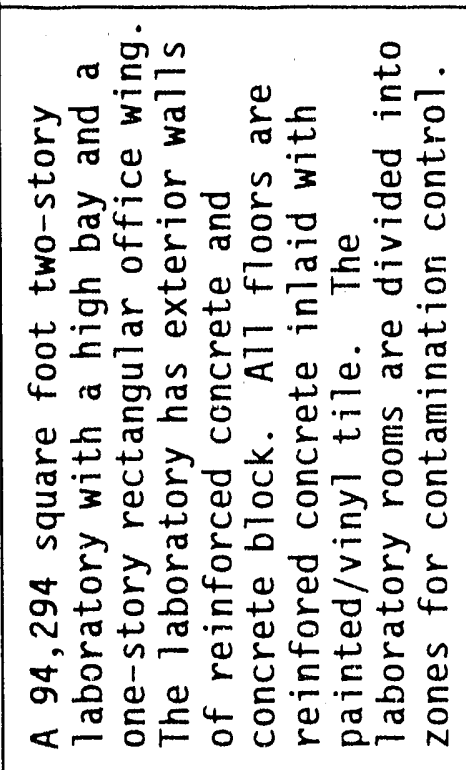 \\
\hline 诌 & $\begin{array}{l}\overline{0} \\
\frac{1}{5} \\
\text { a }\end{array}$ & 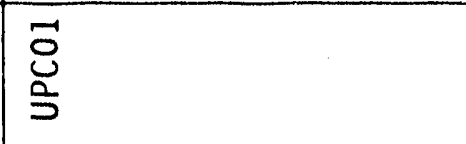 \\
\hline 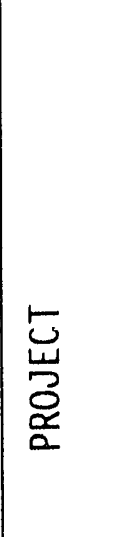 & 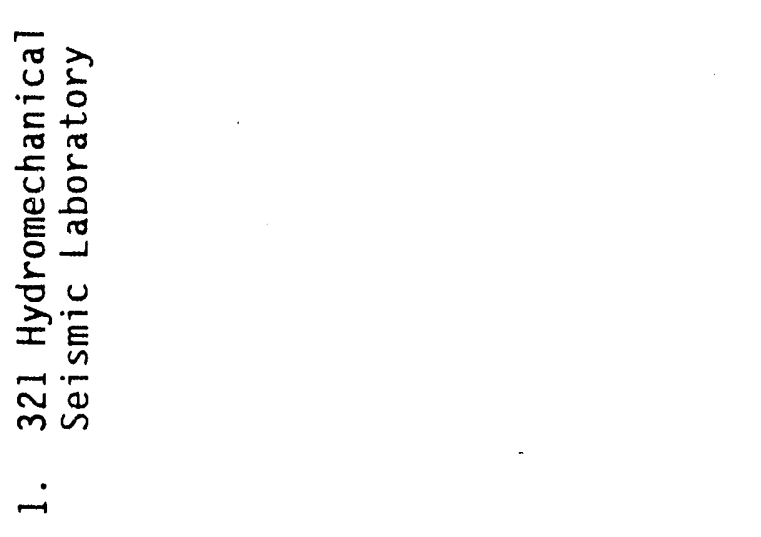 & 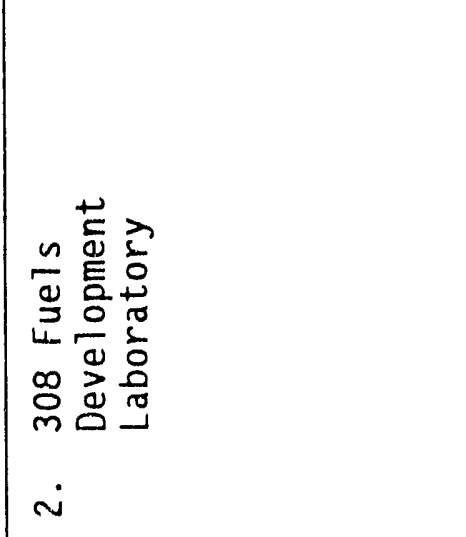 \\
\hline
\end{tabular}


WHC-EP-0231-3

A.9 300 AREA CONTAMINATED FACILITIES. (sheet 2 of 2)

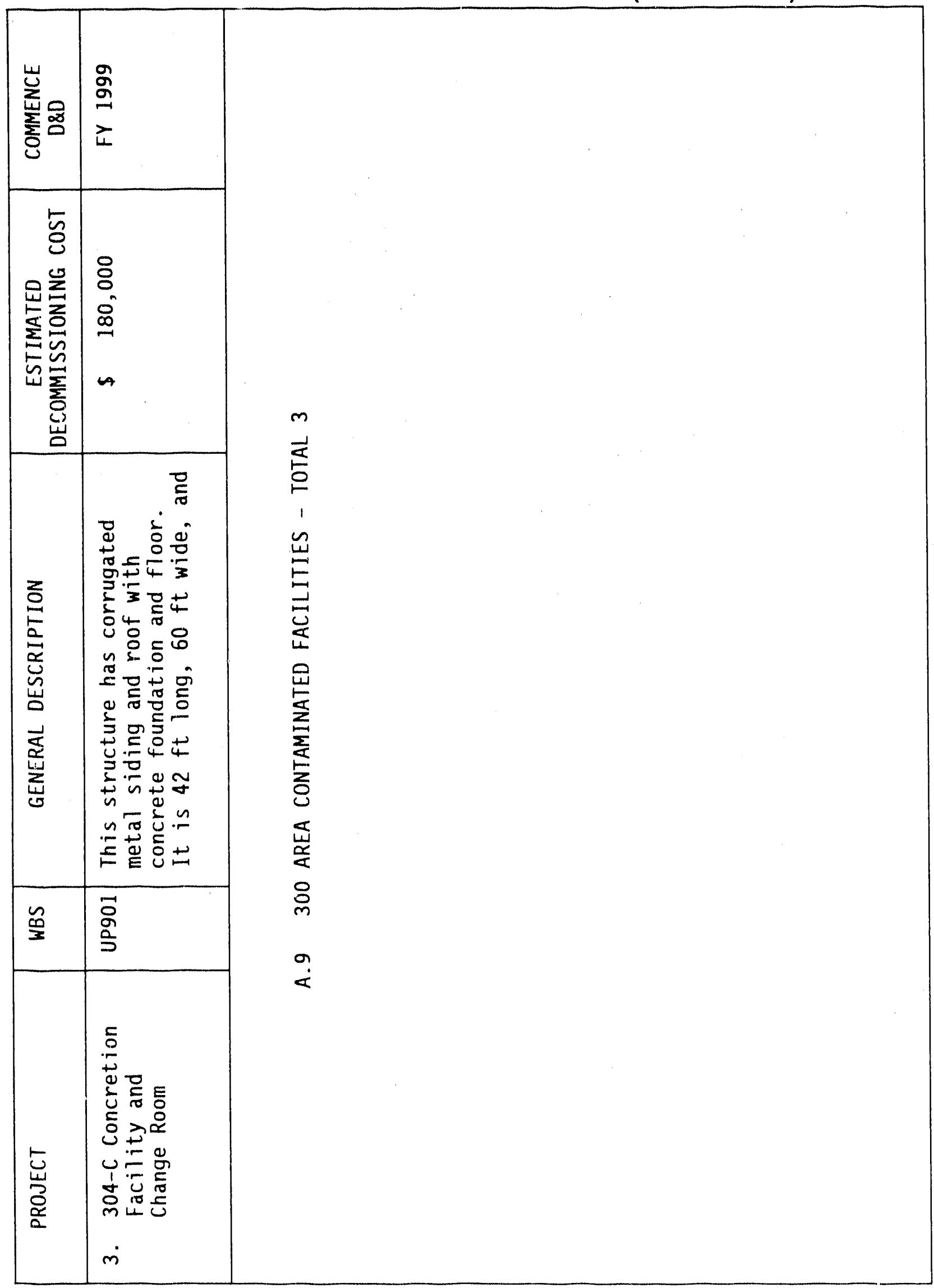


A.10 HANFORD NONCONTAMINATED FACILITIES. (sheet 1 of 7 )

\begin{tabular}{|c|c|c|c|}
\hline 密 & $\begin{array}{l}\circ \\
\stackrel{2}{Ј} \\
亡\end{array}$ & $\begin{array}{l}\stackrel{2}{\varrho} \\
\text { 乙 }\end{array}$ & 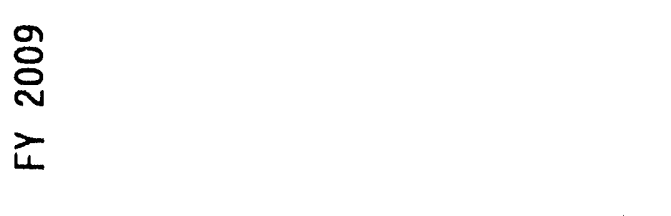 \\
\hline 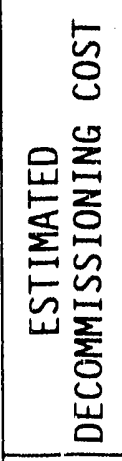 & $\begin{array}{l}8 \\
8 \\
m \\
m\end{array}$ & $\begin{array}{l}8 \\
8 \\
\text { nin } \\
n\end{array}$ & $\begin{array}{l}8 \\
8 \\
\dot{+} \\
\dot{\sigma} \\
n\end{array}$ \\
\hline 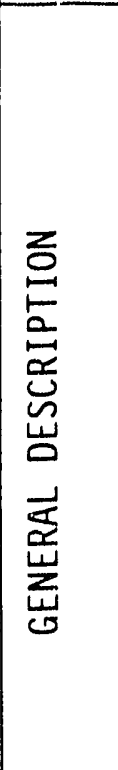 & 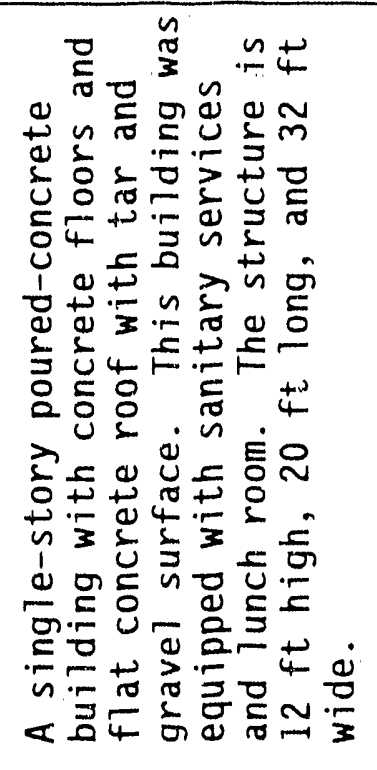 & 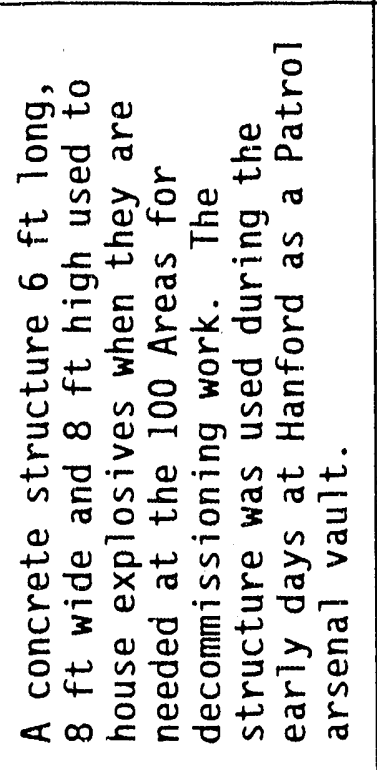 & 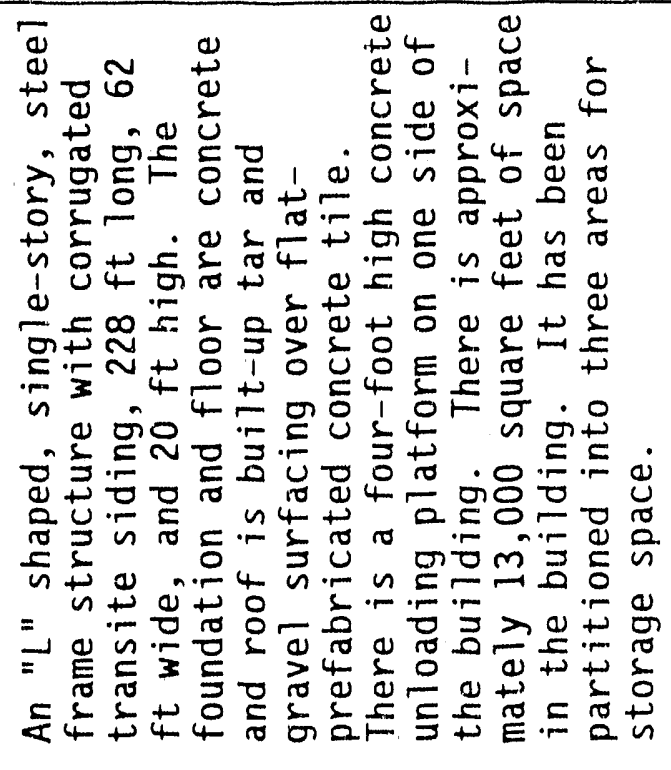 \\
\hline$\frac{\tilde{m}}{\underline{z}}$ & $\begin{array}{l}\widetilde{0} \\
\text { 芆 }\end{array}$ & $\stackrel{\widetilde{\sigma}}{ٍ}$ & 志 \\
\hline 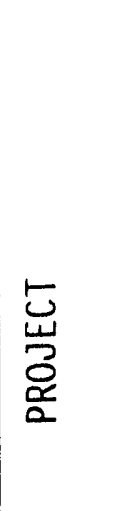 & 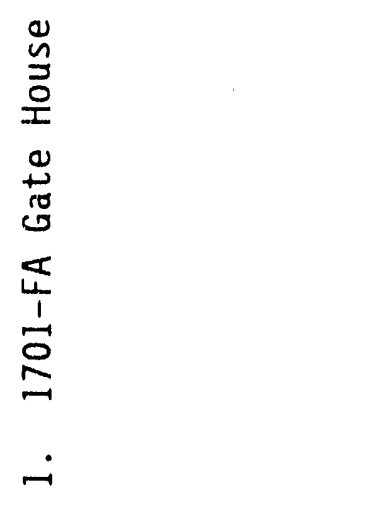 & 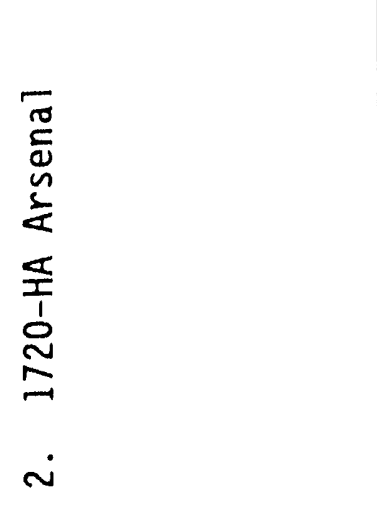 & 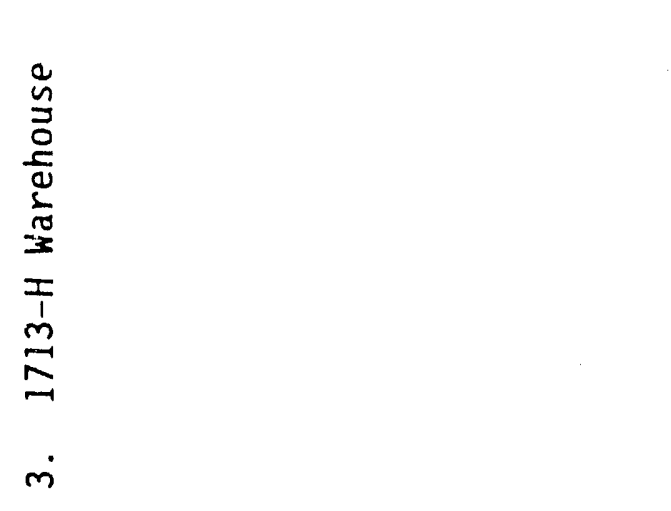 \\
\hline
\end{tabular}


A.10 HANFORD NONCONTAMINATED FACILITIES. (sheet 2 of 7)

\begin{tabular}{|c|c|c|c|c|c|}
\hline 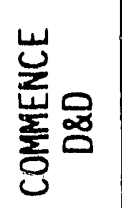 & 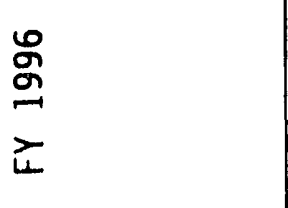 & $\begin{array}{l}\text { Oे } \\
\text { D } \\
\text { z }\end{array}$ & $\begin{array}{l}\text { O } \\
\text { ㅇ } \\
\text { ঠ }\end{array}$ & $\begin{array}{l}\text { Oे } \\
\text { ㅇ } \\
\text { 亡 }\end{array}$ & $\begin{array}{l}\text { o } \\
\text { 인 } \\
\text { خ }\end{array}$ \\
\hline 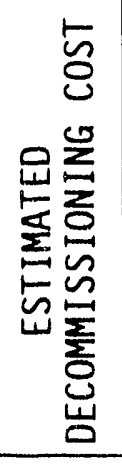 & $\begin{array}{l}8 \\
0 \\
n \\
n\end{array}$ & $\begin{array}{l}8 \\
8 \\
\infty \\
\infty \\
\sim\end{array}$ & $\begin{array}{l}8 \\
8 \\
\text { n }\end{array}$ & $\begin{array}{l}8 \\
0 \\
6 \\
0\end{array}$ & $\begin{array}{l}8 \\
0 \\
0 \\
0\end{array}$ \\
\hline 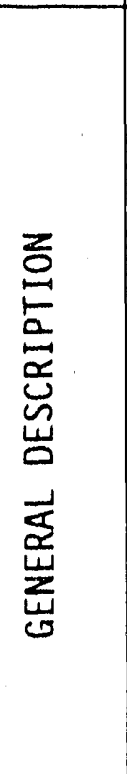 & 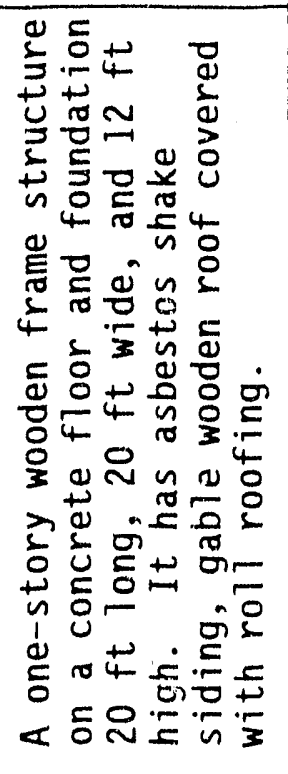 & 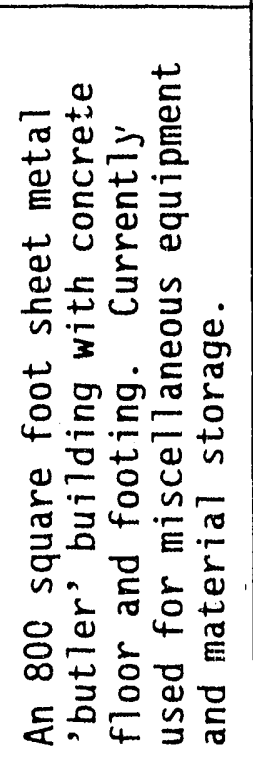 & 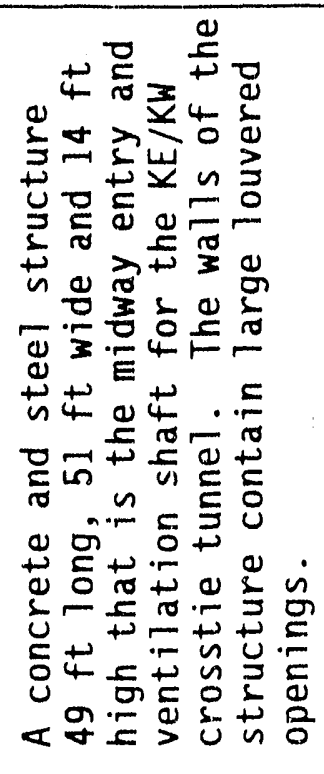 & 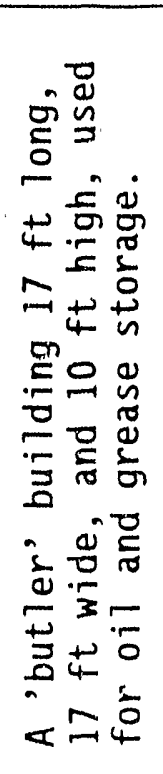 & 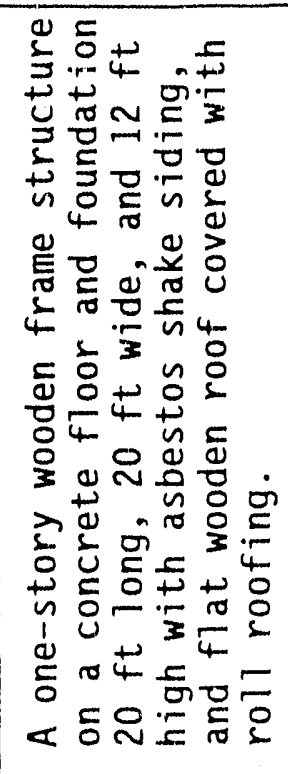 \\
\hline 旡 & $\begin{array}{l}\text { ¿े } \\
3\end{array}$ & 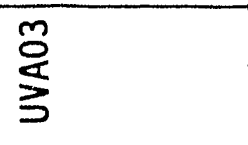 & $\begin{array}{l}\stackrel{2}{0} \\
+ \\
3\end{array}$ & $\stackrel{\text { 号 }}{\stackrel{1}{1}}$ & $\begin{array}{l}2 \\
\\
3\end{array}$ \\
\hline $\begin{array}{l}5 \\
\text { 岁 } \\
\text { \& }\end{array}$ & 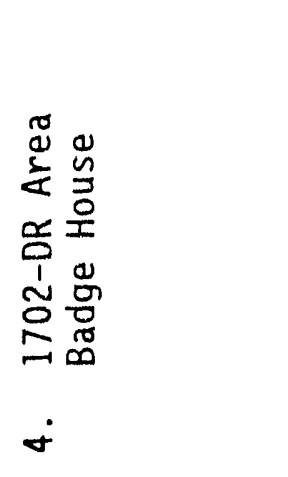 & 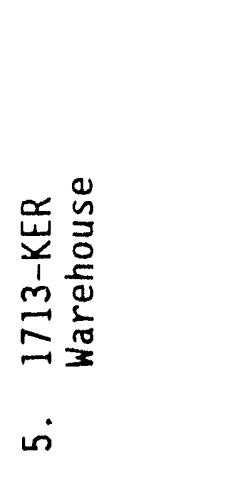 & 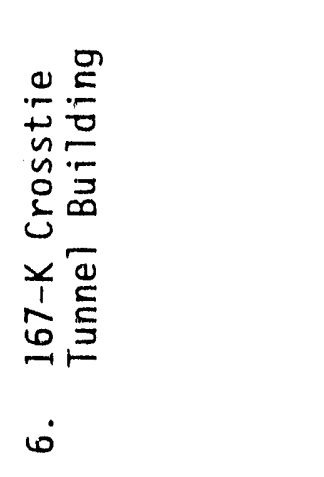 & 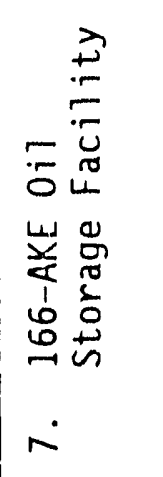 & 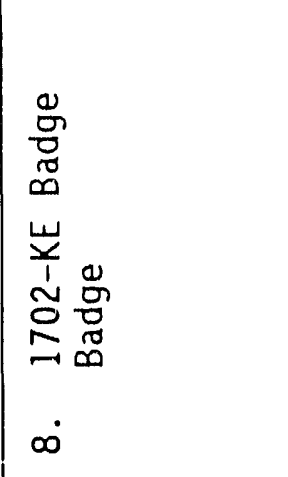 \\
\hline
\end{tabular}


A.10 HANFORD NONCONTAMINATED FACILITIES. (sheet 3 of 7)

\begin{tabular}{|c|c|c|c|c|}
\hline 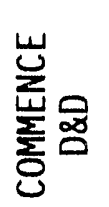 & 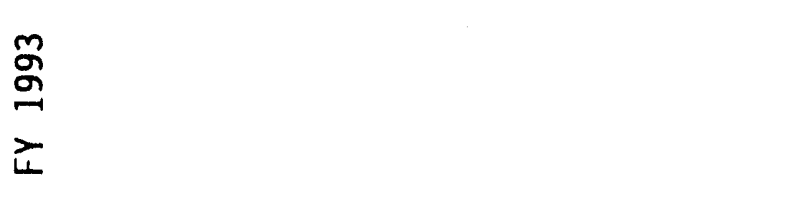 & $\begin{array}{l}\text { : } \\
\stackrel{2}{2} \\
\text { 亡 }\end{array}$ & $\begin{array}{l}\infty \\
\stackrel{0}{2} \\
\longleftarrow\end{array}$ & $\begin{array}{l}\mathscr{2} \\
\text { ప } \\
\text { 亡े }\end{array}$ \\
\hline 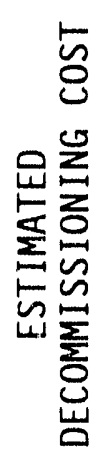 & 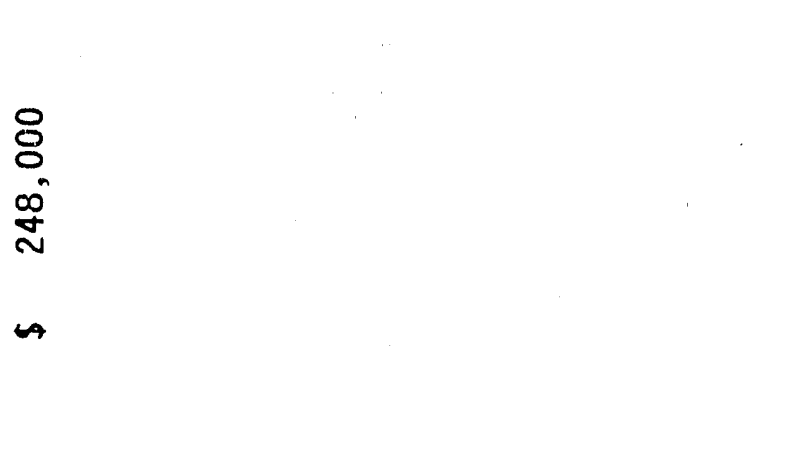 & $\begin{array}{l}8 \\
0 \\
0\end{array}$ & $\begin{array}{l}8 \\
0 \\
0 \\
0\end{array}$ & $\begin{array}{l}8 \\
8 \\
\text { in } \\
\text { n }\end{array}$ \\
\hline 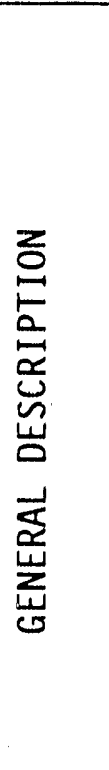 & 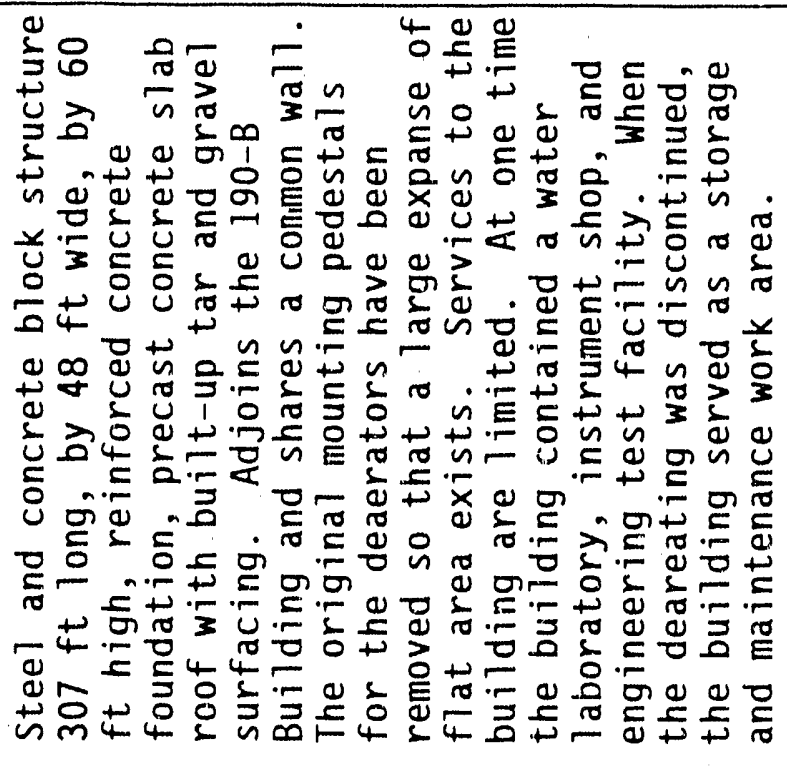 & 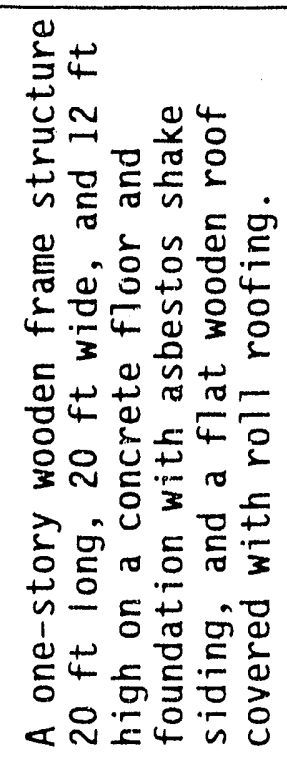 & 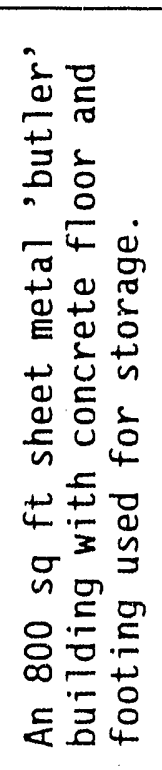 & 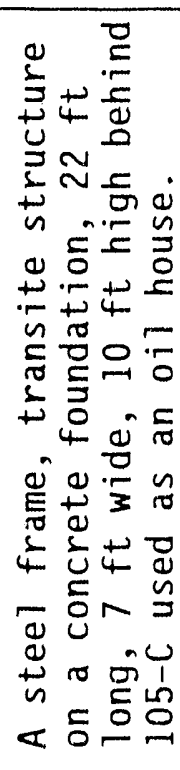 \\
\hline$\stackrel{\tilde{m}}{3}$ & 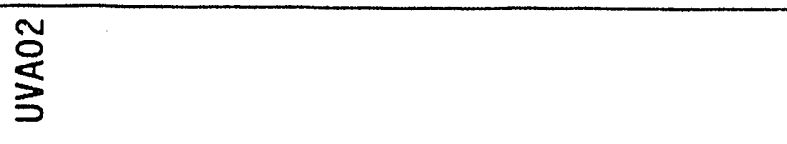 & $\begin{array}{l}\mathscr{0} \\
3 \\
3\end{array}$ & 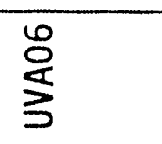 & 嚆 \\
\hline $\begin{array}{l}\text { 总 } \\
\text { o } \\
\text { व. }\end{array}$ & 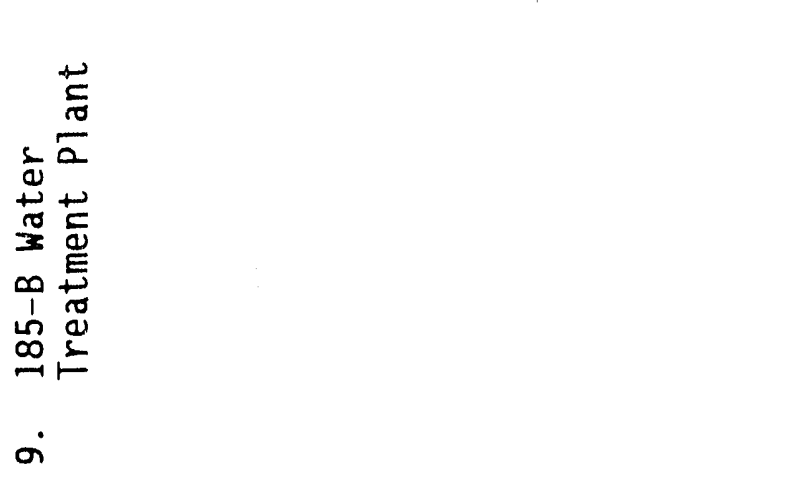 & 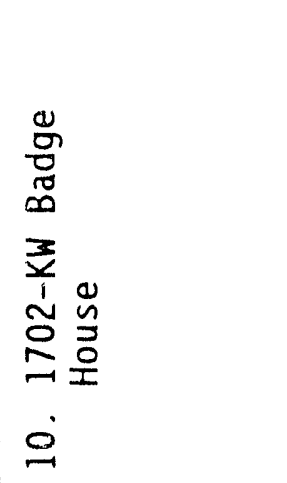 & 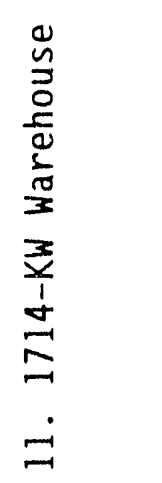 & 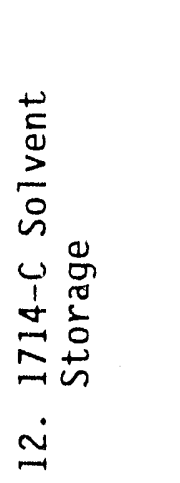 \\
\hline
\end{tabular}


A.10 HANFORD NONCONTAMINATED FACILITIES. (sheet 4 of 7)

\begin{tabular}{|c|c|c|}
\hline 岂 & $\begin{array}{l}\text { ò } \\
\text { i } \\
\text { خ }\end{array}$ & $\begin{array}{l}\stackrel{0}{0} \\
\text { 군 }\end{array}$ \\
\hline 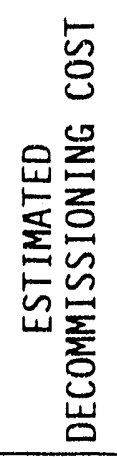 & $\begin{array}{l}\text { ठे } \\
\text { مी }\end{array}$ & 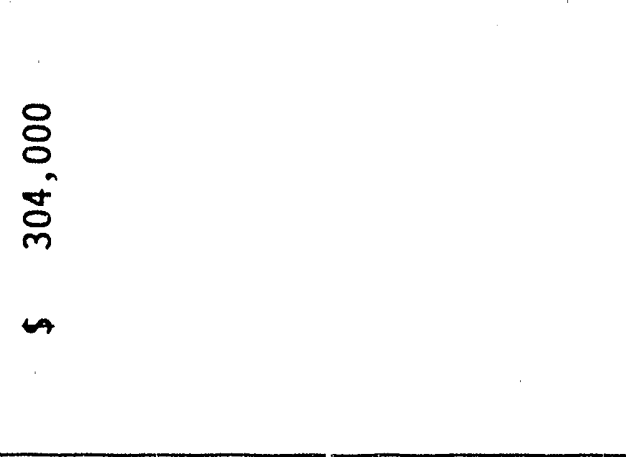 \\
\hline 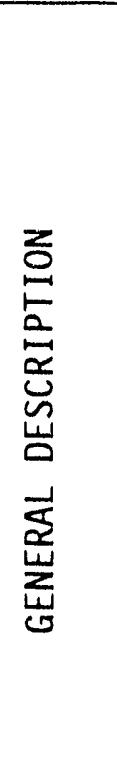 & 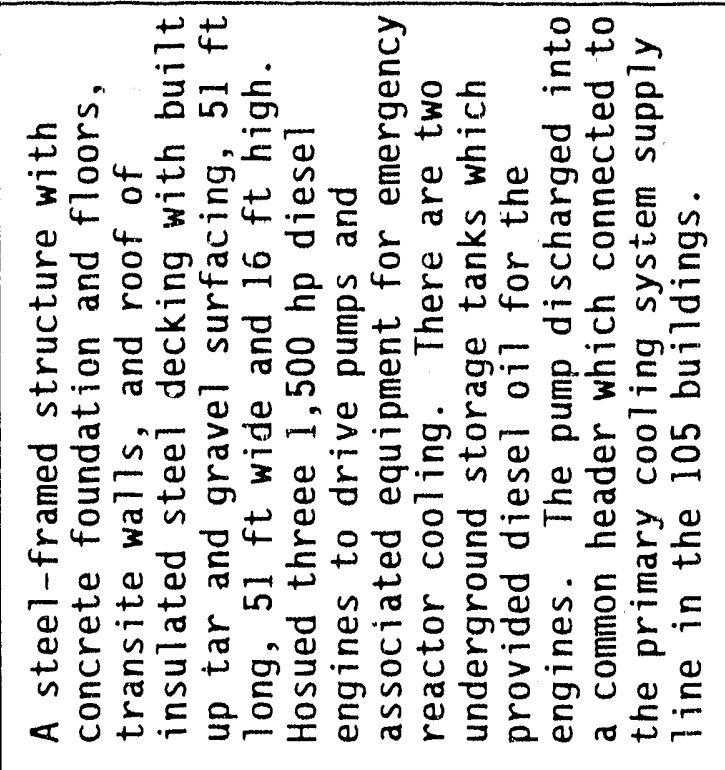 & 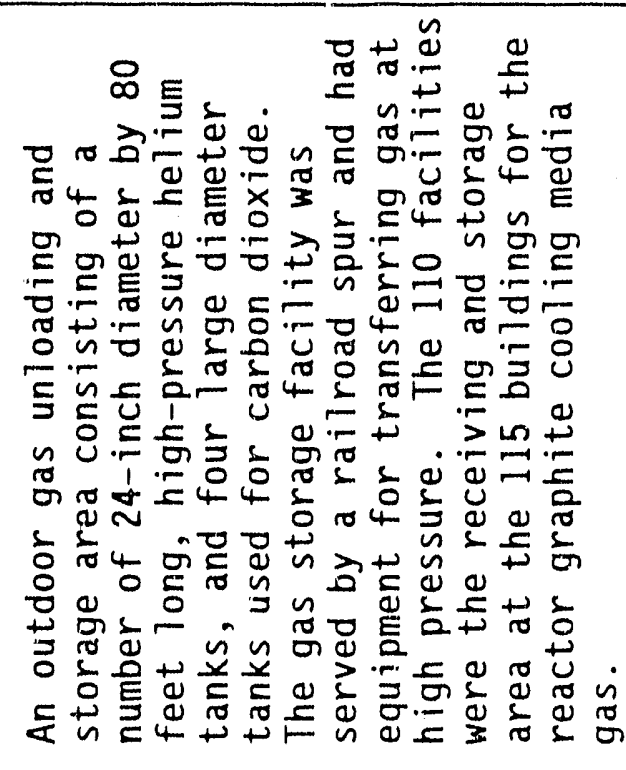 \\
\hline$\tilde{m}$ & $\begin{array}{l}0 \\
\text { Oे } \\
3\end{array}$ & 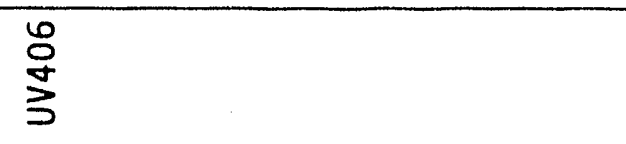 \\
\hline $\begin{array}{l}\bar{u} \\
\text { 岂 } \\
\text { \& }\end{array}$ & 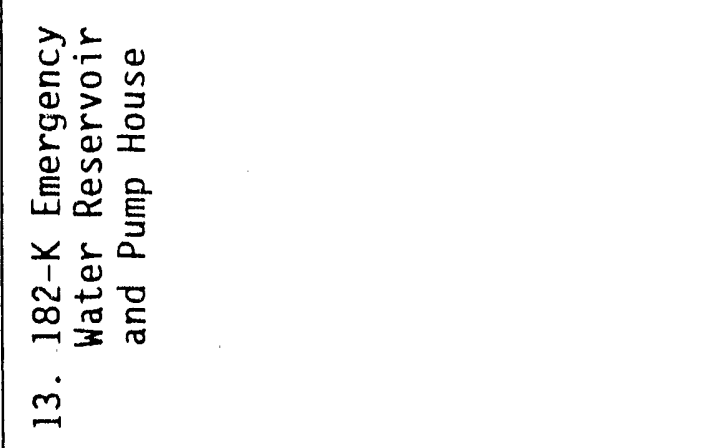 & 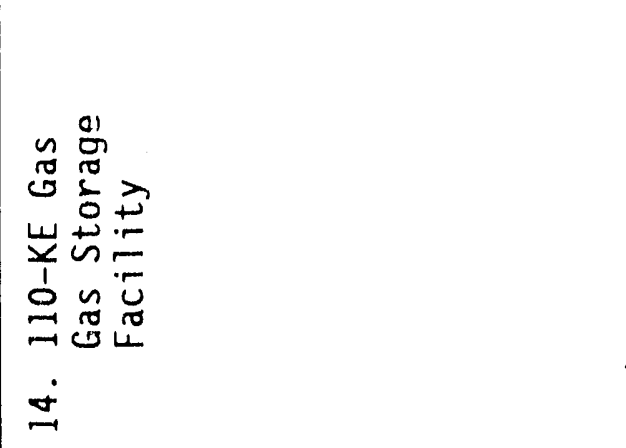 \\
\hline
\end{tabular}


A.10 HANFORD NONCONTAMINATED FACILITIES. (sheet 5 of 7)

\begin{tabular}{|c|c|c|c|c|}
\hline 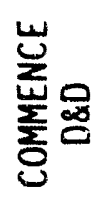 & $\begin{array}{l}\text { 움 } \\
\text { 는 }\end{array}$ & $\begin{array}{l}\stackrel{\circ}{\varrho} \\
\frac{2}{4}\end{array}$ & 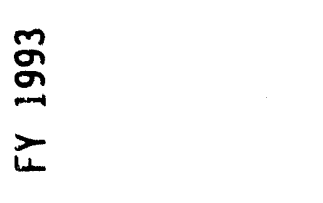 & $\begin{array}{l}\text { Ò } \\
\text { D } \\
2\end{array}$ \\
\hline 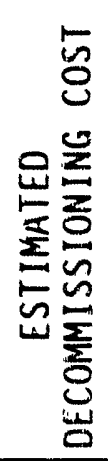 & $\begin{array}{l}\stackrel{8}{0} \\
\dot{0} \\
\text { in } \\
\text { in }\end{array}$ & $\begin{array}{l}8 \\
8 \\
\text { n }\end{array}$ & $\begin{array}{l}8 \\
8 \\
0 \\
0 \\
6 \\
- \\
-1\end{array}$ & $\begin{array}{l}8 \\
\circ \\
\sigma \\
n\end{array}$ \\
\hline 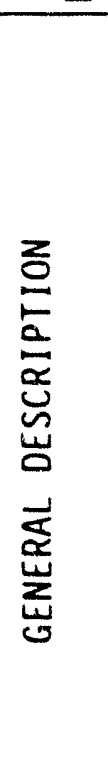 & 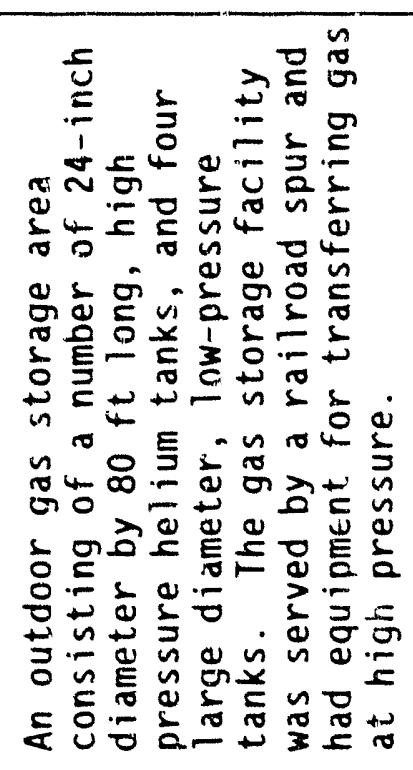 & 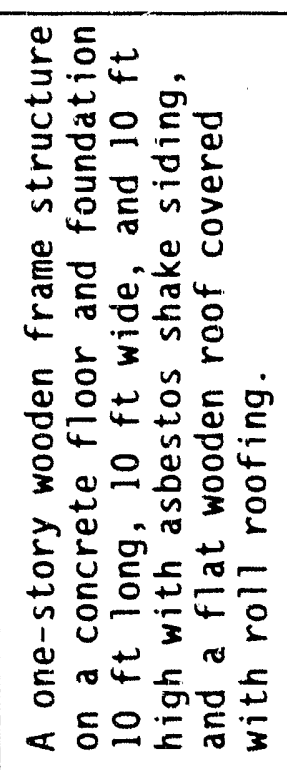 & 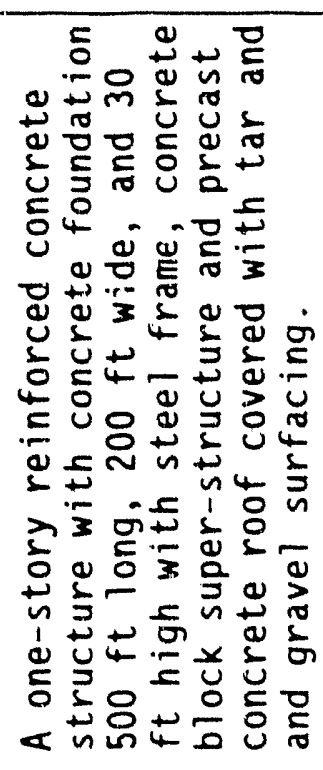 & 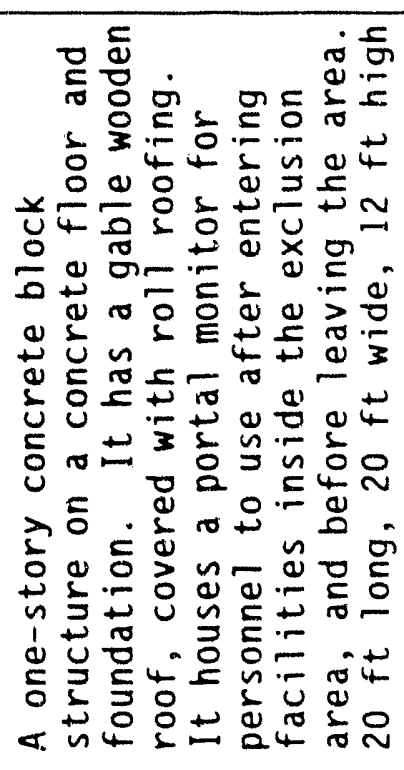 \\
\hline$\hat{\mathfrak{g}}$ & 产 & $\begin{array}{l}\text { ma } \\
\text { 商 }\end{array}$ & 草 & 京 \\
\hline 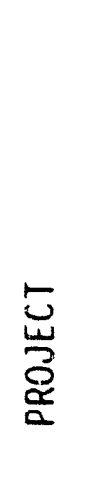 & 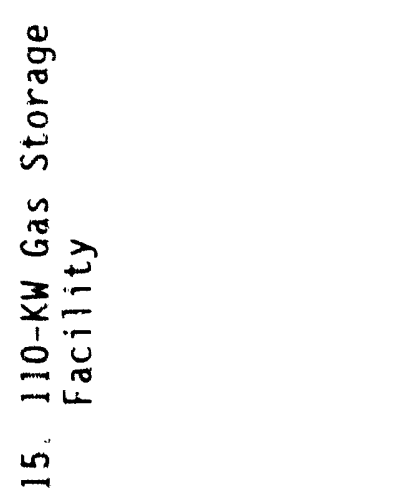 & 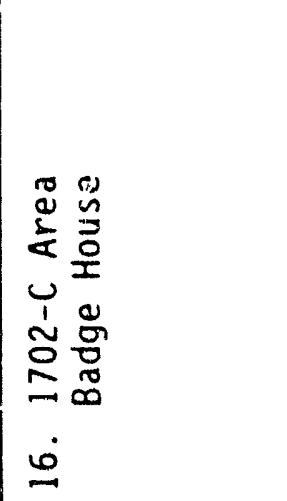 & 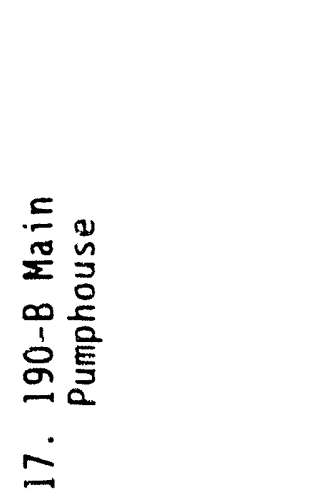 & 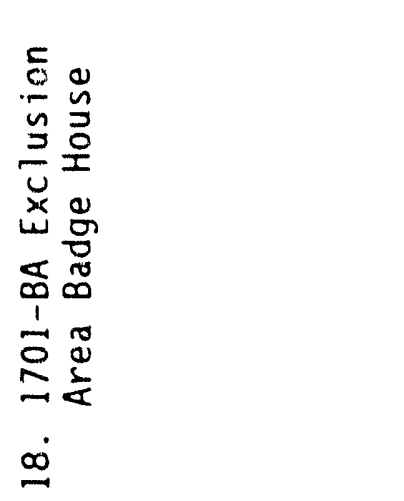 \\
\hline
\end{tabular}


A. 10 HANFORD NONCONTAMINATED FACILITIES. (sheet 6 of 7)

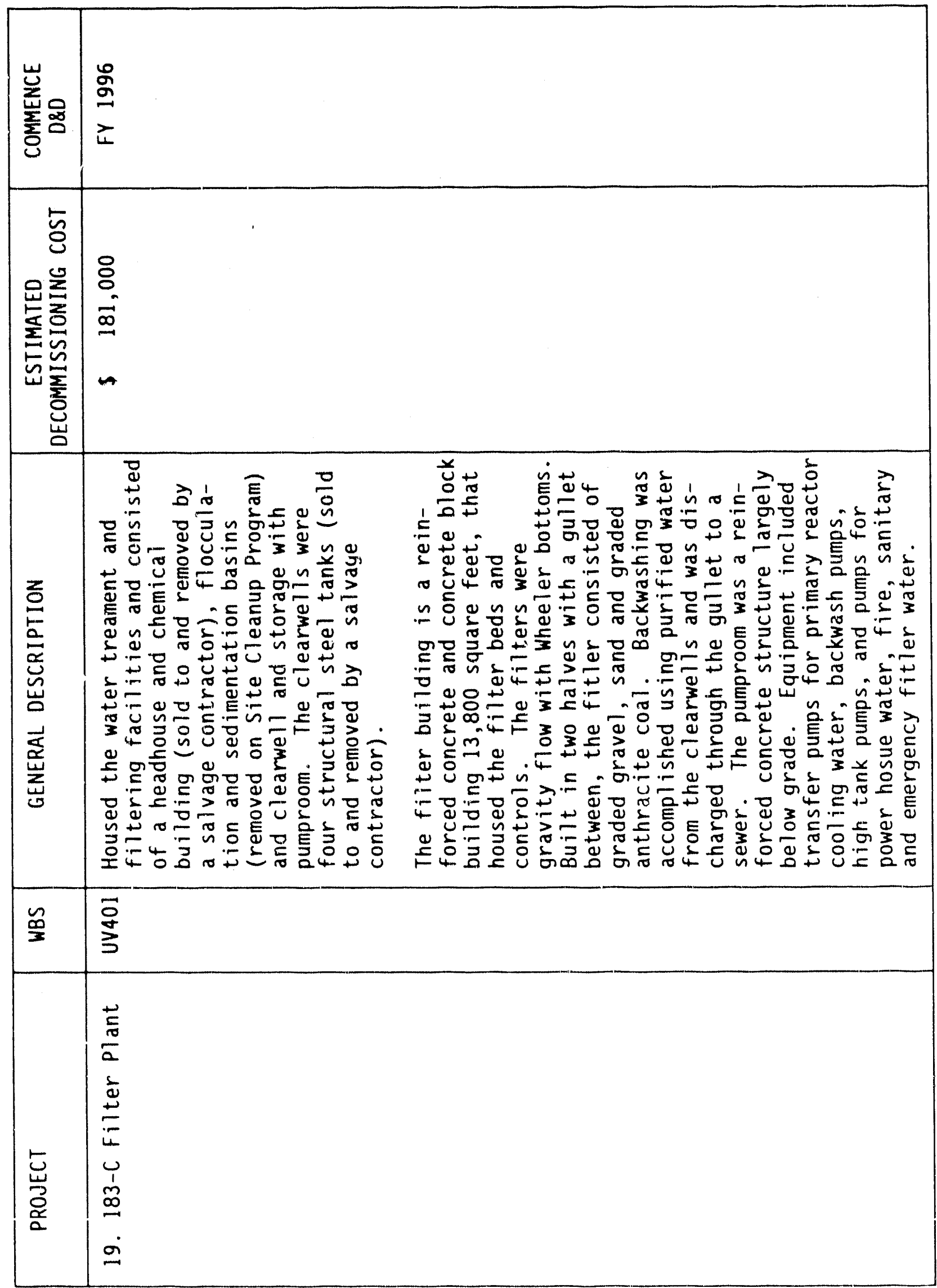


WHC-EP-0231-3

A. 10 HANFORD NONCONTAMINATED FACILITIES. (sheet 7 of 7)

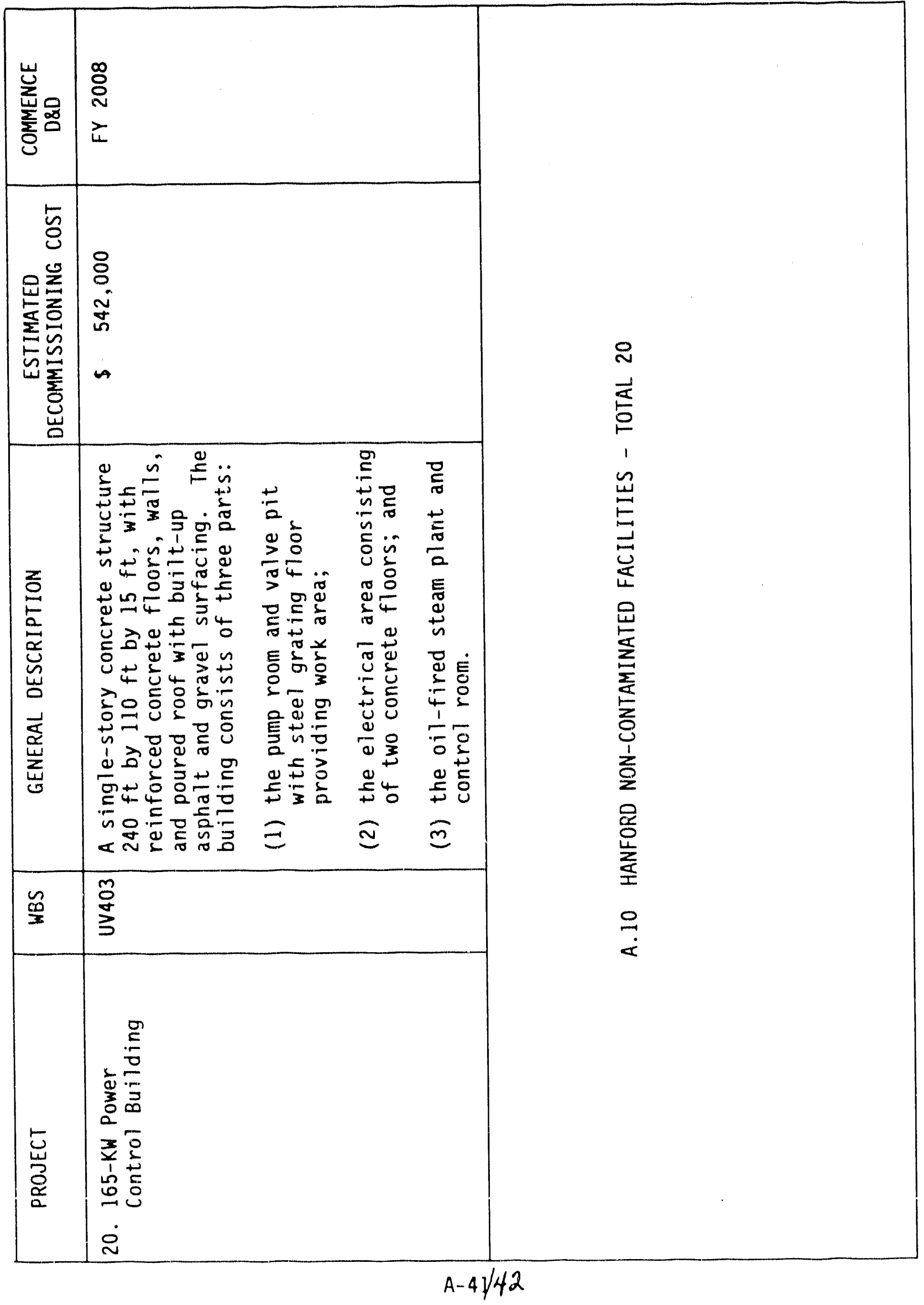


A.11 200 AREA STORAGE VAULTS.

\begin{tabular}{|c|c|c|c|}
\hline 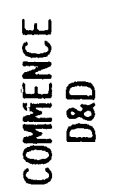 & $\begin{array}{l}0 \\
\text { O } \\
\searrow \\
亡\end{array}$ & 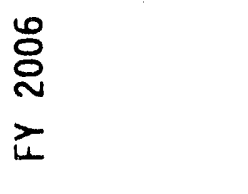 & \\
\hline 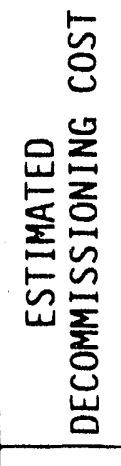 & 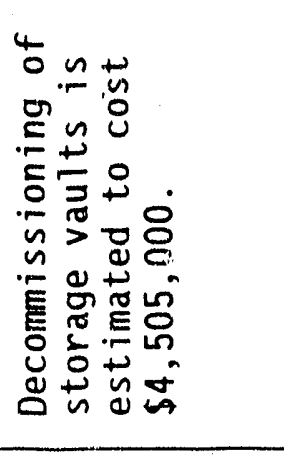 & 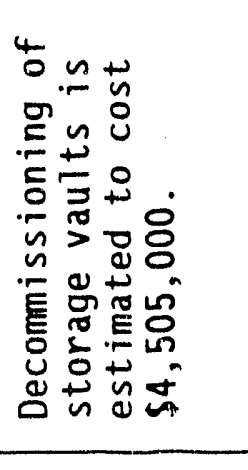 & $\begin{array}{r}\sim \\
\mathbb{E}\end{array}$ \\
\hline 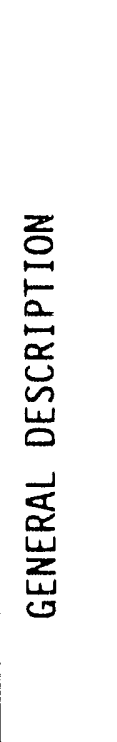 & 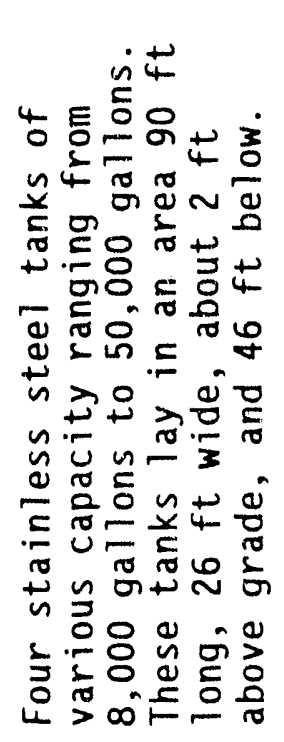 & 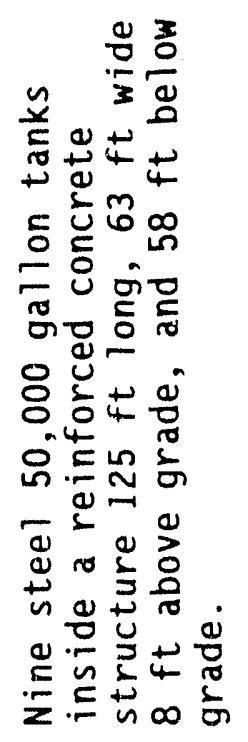 & 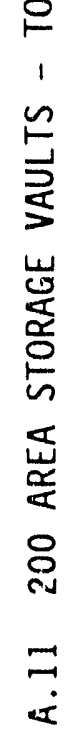 \\
\hline$\tilde{\infty}$ & 官 & 芩 & \\
\hline 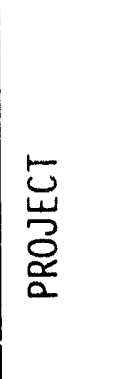 & $\begin{array}{l}\frac{\omega}{J} \\
\stackrel{0}{J} \\
\frac{\alpha}{J} \\
1 \\
\stackrel{J}{\sim} \\
\dot{\sim}\end{array}$ & 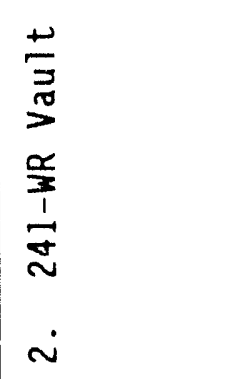 & \\
\hline
\end{tabular}


WHC-EP-0231-3

\section{APPENDIX B}

\section{AREA SITE MAPS}

NOTE: The 600 Area map is included to show the location of 212-N, 212-P, and 212-R Storage Buildings, which are the only facilities in the Hanford Surplus Facilities Program (HSFP) Plan that are not inside or in close proximity to the 100 and 200 Area boundaries. 


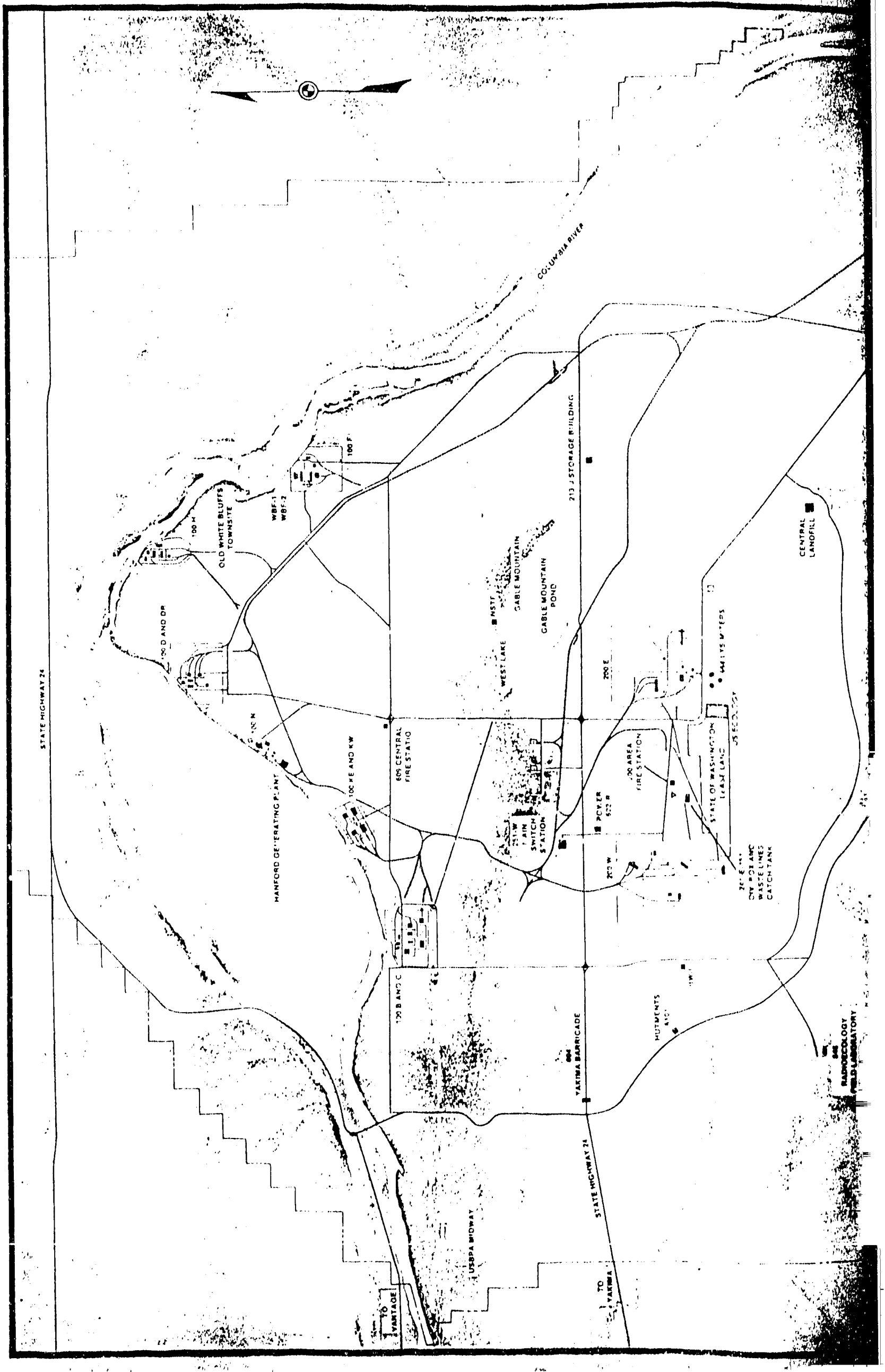




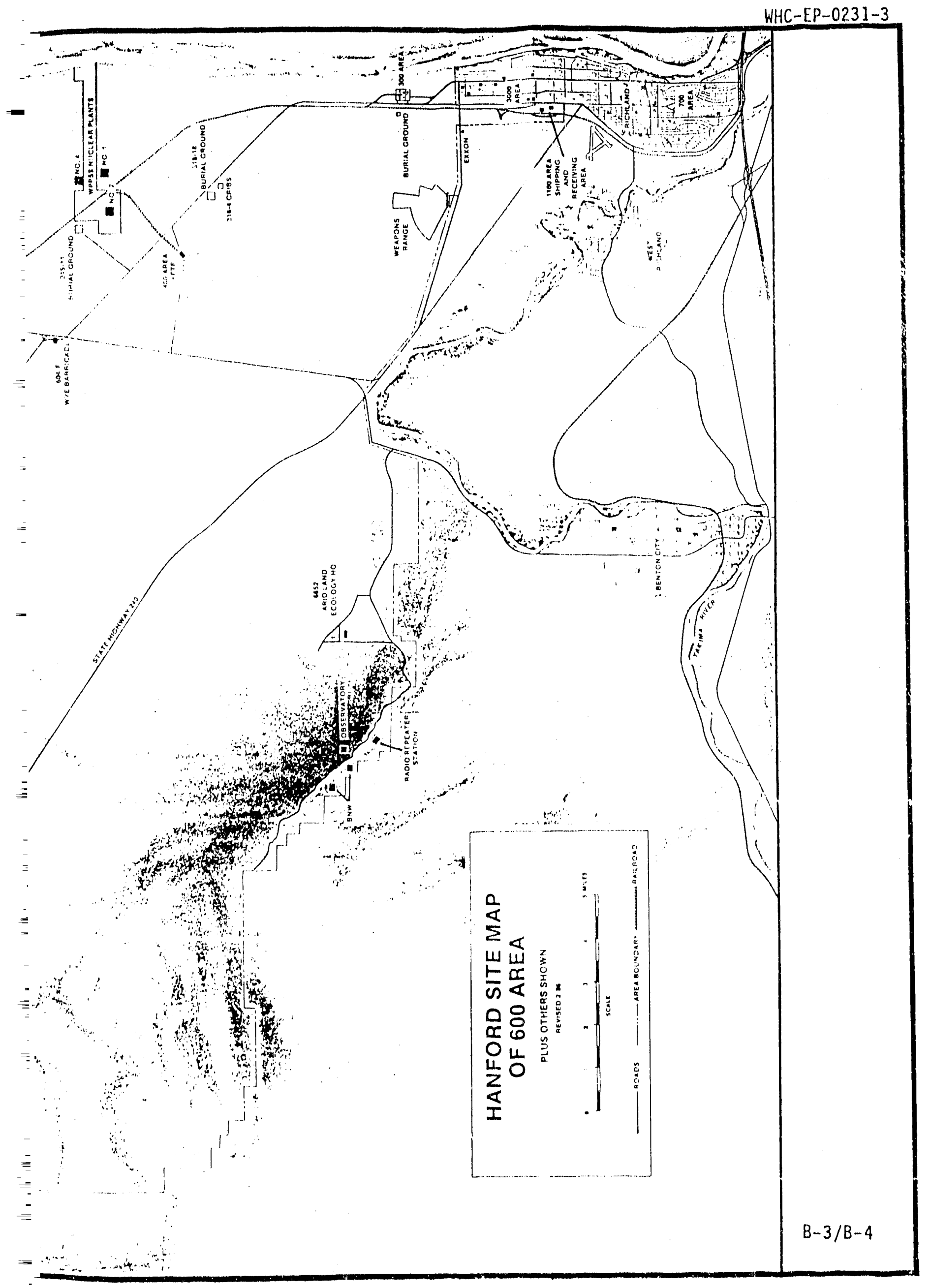




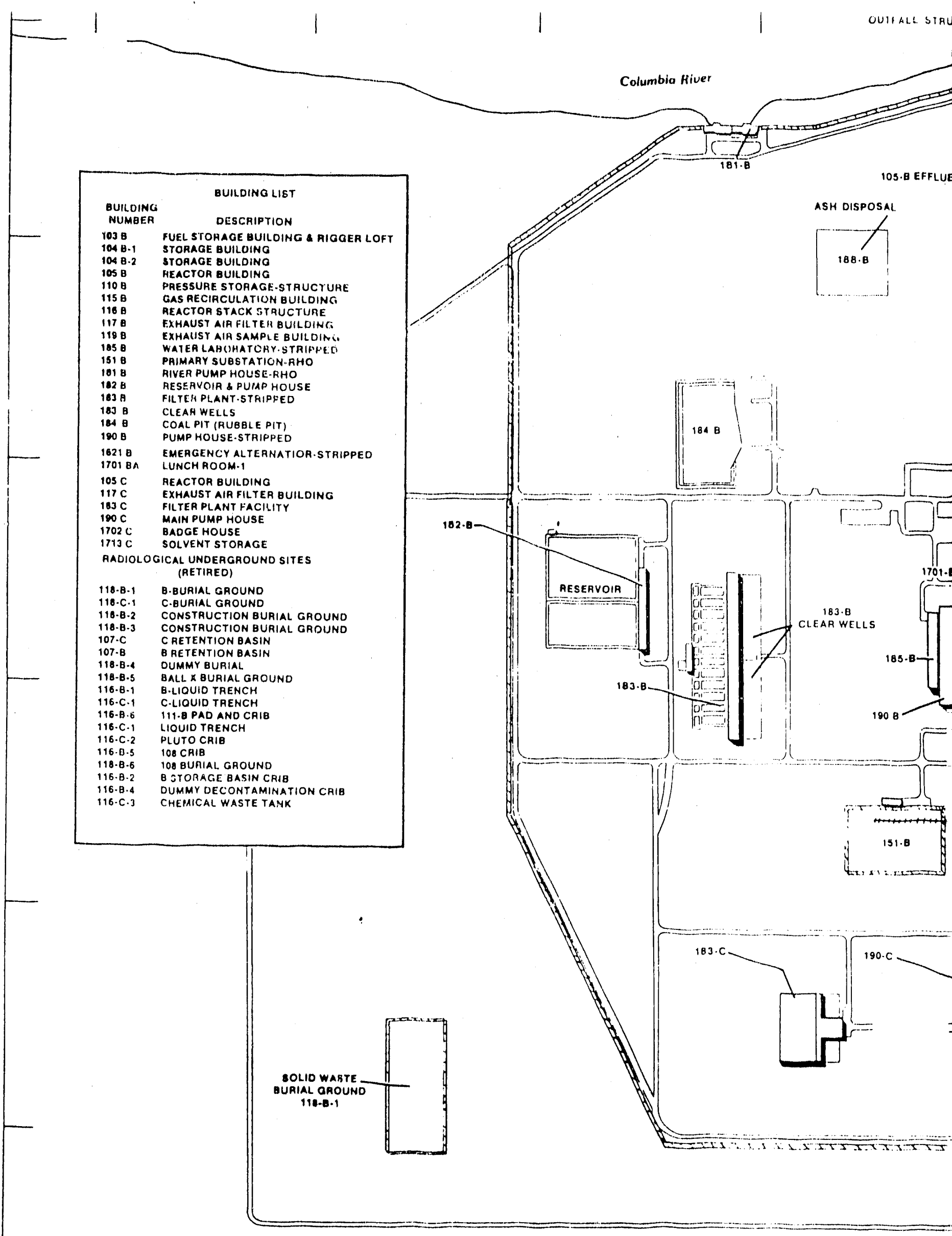




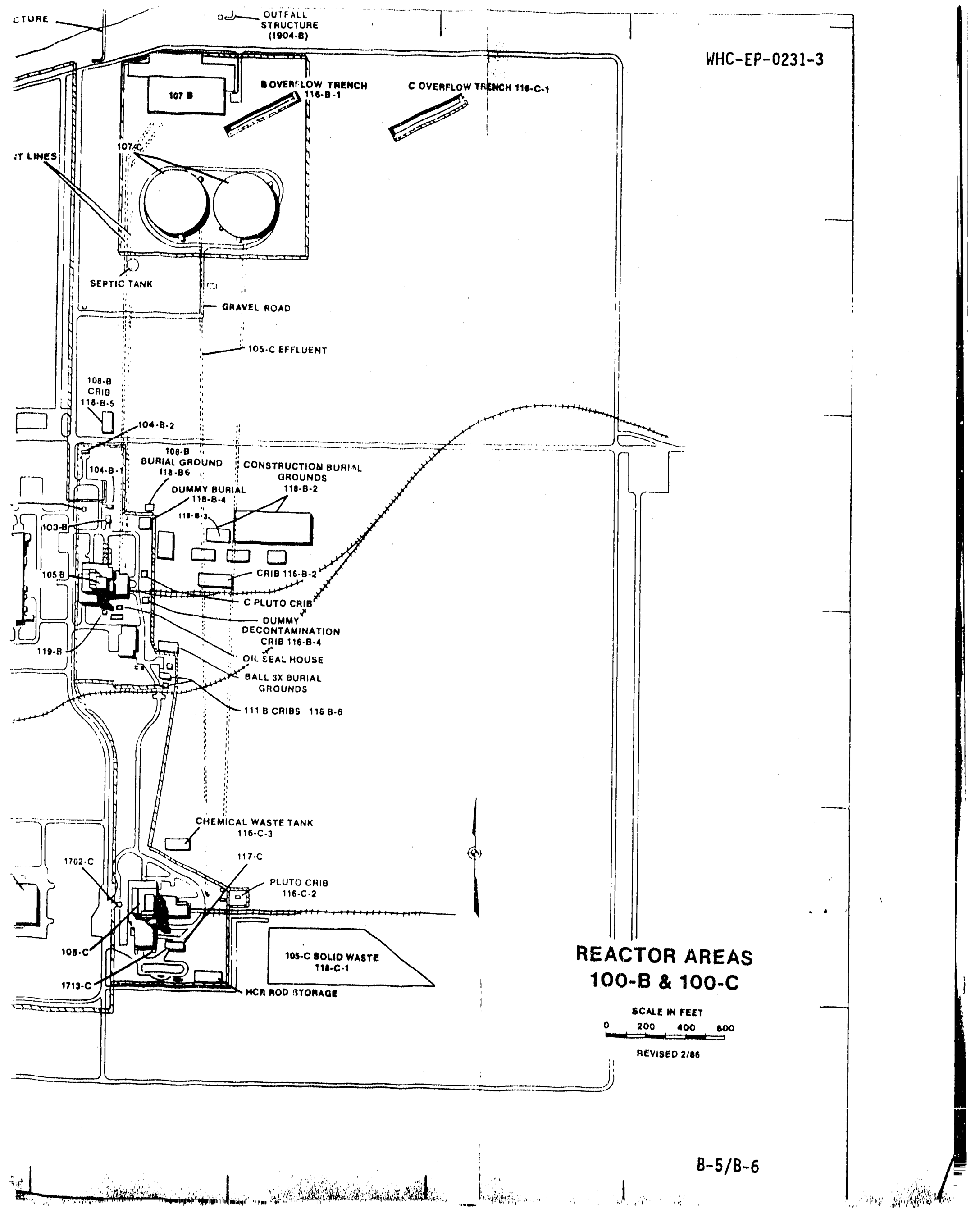




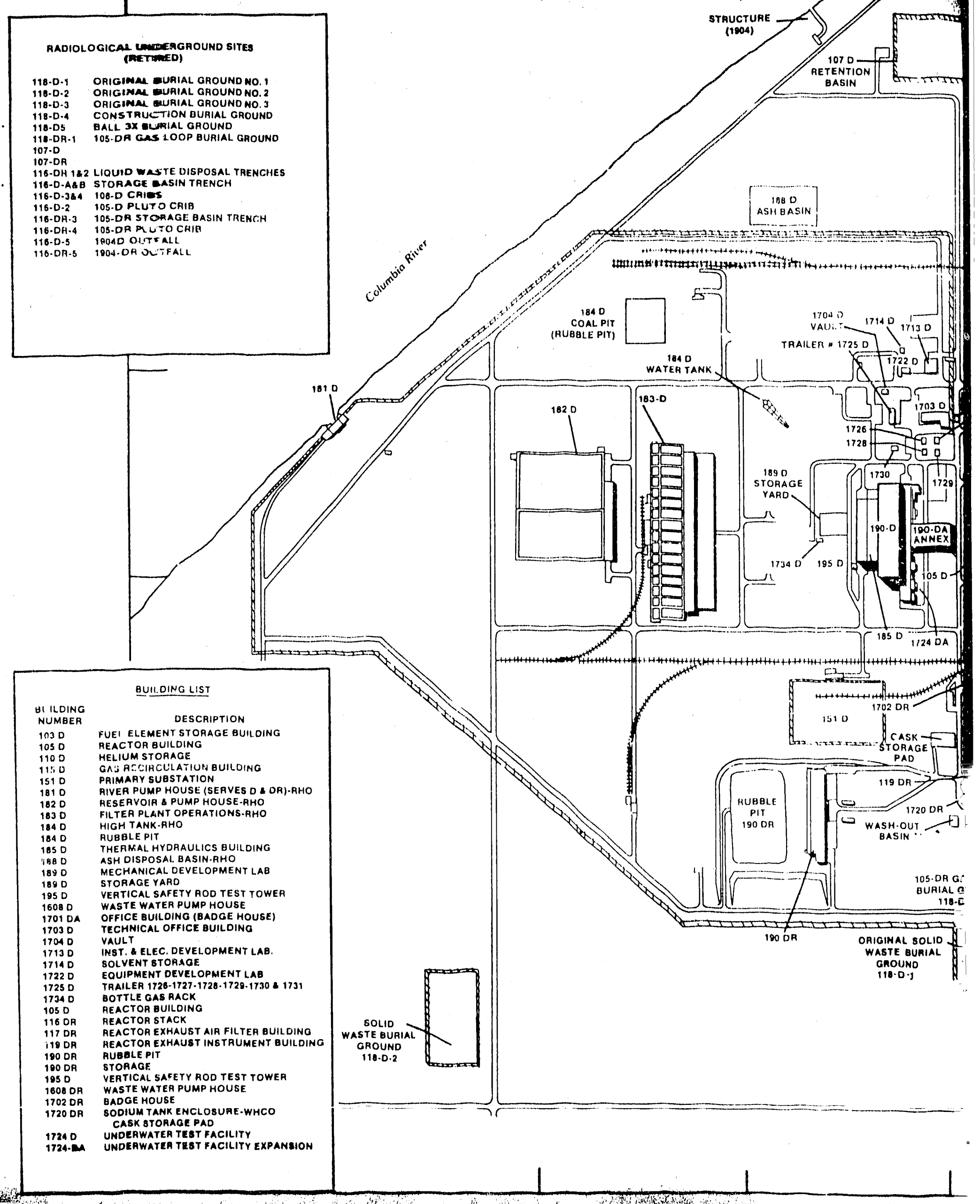




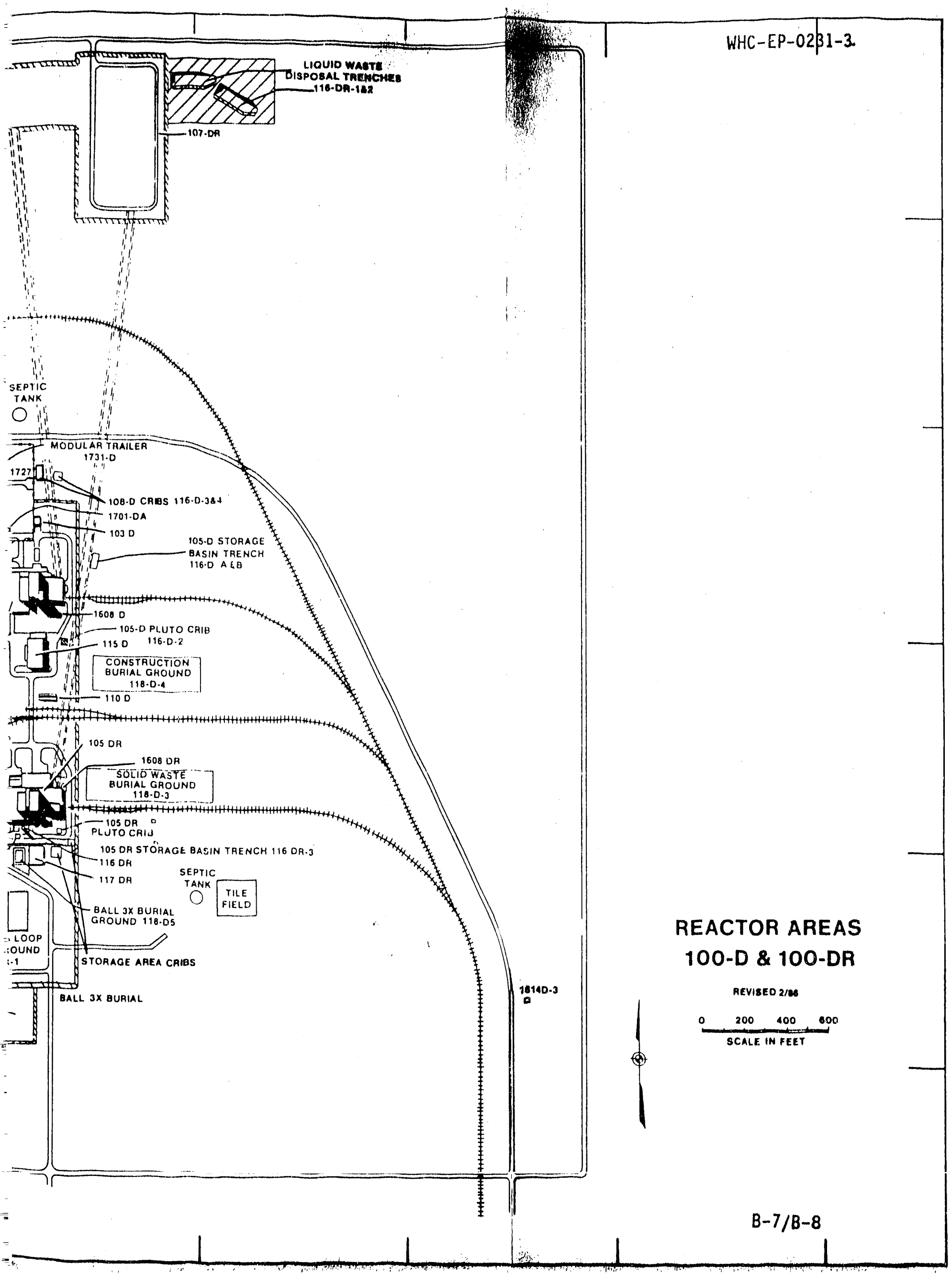




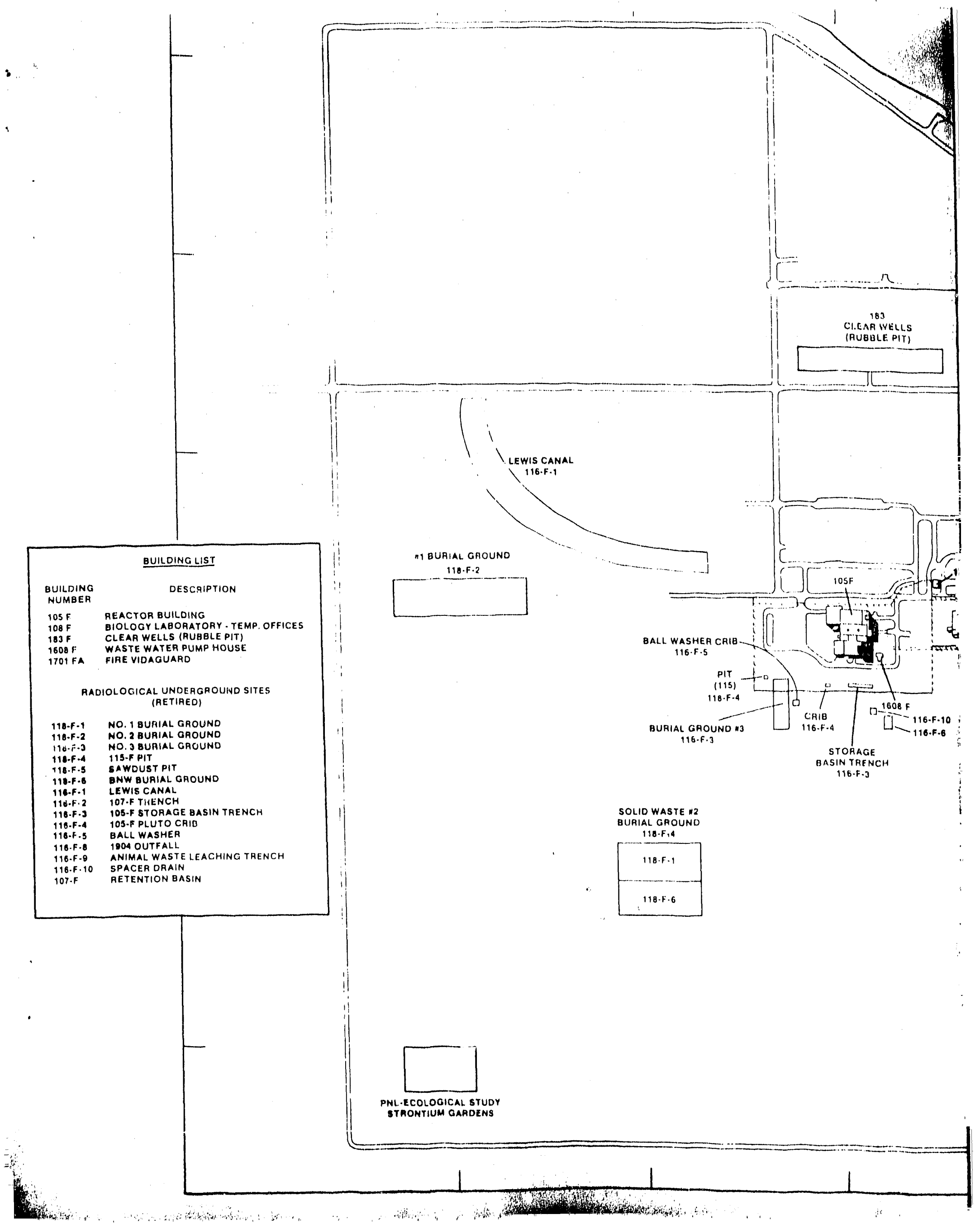




\begin{tabular}{|c|c|}
\hline \multicolumn{2}{|r|}{ BUILDINO L.IST } \\
\hline $\begin{array}{l}\text { BUILDING } \\
\text { NUMBER }\end{array}$ & DESCAIPTION \\
\hline $\begin{array}{l}183 H \\
105 H \\
1806 H \\
1713 H \\
1720 H\end{array}$ & $\begin{array}{l}\text { SOLAR PONDS L CLEAR WELLS } \\
\text { (RUBBLEPIT) } \\
\text { REACTOO BUILDING } \\
\text { WASTE WATEA PUMP HOUSE } \\
\text { WAREHOUSE } \\
\text { ARSENAL }\end{array}$ \\
\hline & $\begin{array}{l}\text { AADIOLOGICAL UNDEAGAOUND SITES } \\
\text { (RETIRED }\end{array}$ \\
\hline $190-H-1$ & BURIAL CIAOUND \\
\hline $198-H \cdot 2$ & BUAIAL GAOUND.iNS \\
\hline $107 \cdot \mathrm{H}$ & RETENTION BASIN \\
\hline $118-H \cdot 3$ & CONSTAUCTION BUAIAL GROUND \\
\hline $116 \cdot H \cdot 1$ & LIQUID WASTE TRENCY \\
\hline $116-H \cdot 2$ & 1608 CA18 \\
\hline $118-H \cdot 5$ & ROD CAVE \& THIMBLE PIT \\
\hline $118-H \cdot 4$ & BALL JX BURIAL \\
\hline $118 \cdot H \cdot 3$ & DECONTAMINATION PIT \\
\hline
\end{tabular}



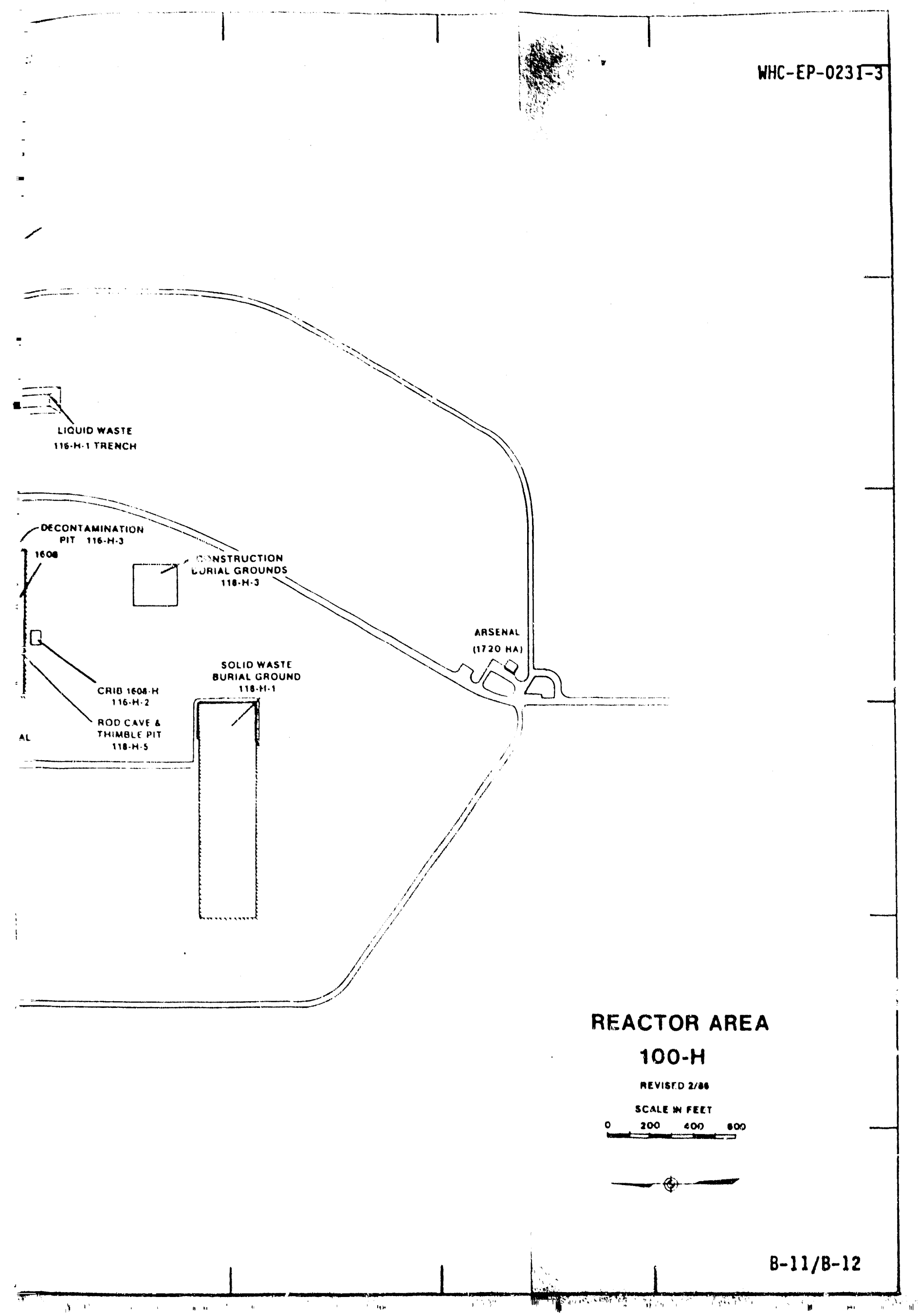
$\mid$

$\mid$

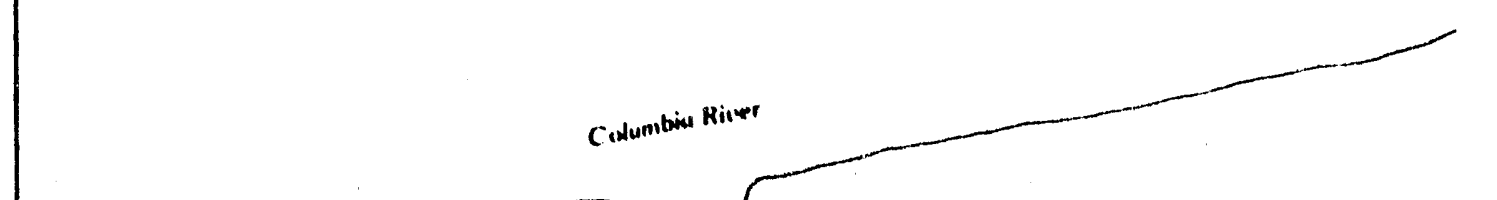

\begin{tabular}{|c|c|}
\hline \multicolumn{2}{|r|}{ BUILOINGLISI } \\
\hline $\begin{array}{l}\text { BUILDING } \\
\text { NUMBER }\end{array}$ & DESCAIPTION \\
\hline $\operatorname{los} \mathrm{kW}$ & AEACTOA BUILOING \\
\hline $107 \mathrm{~kW}$ & WATER AETENTION BASIN \\
\hline $110 \mathrm{~kW}$ & GAS STOAAGE \\
\hline $115 \mathrm{KW}$ & GAS AECIACULATION BUILDING \\
\hline $116 \mathrm{kw}$ & REACTOA STACK \\
\hline $117 \mathrm{KW}$ & EXHAUST AIA FILTER BUILOING \\
\hline $110 \mathrm{KW}$ & EXMAUST AIR SAMPLE BUILOING \\
\hline $150 \mathrm{~kW}$ & MEAT RECOVERY FACILITY \\
\hline $151 \mathrm{~K}$ & SWITCMING STATION \\
\hline $151 \mathrm{~kW}$ & SUESTATION $230 . \mathrm{KV}$ \\
\hline $165 \mathrm{~kW}$ & POWEA CONTAOL BUILDING \\
\hline $166 \mathrm{~kW}$ & OIL BUNKEA \\
\hline $167 k$ & CAOSS TILE TUNNEL BUILDING \\
\hline $101 \mathrm{~kW}$ & AIVER PUMP STATION \\
\hline $182 \times$ & EMERGENCY WATER PUMP HOUSE \\
\hline $103 \mathrm{~kW}$ & FILTER PLANT \\
\hline $18 \mathrm{~K} \mathrm{KW}$ & CHLORINE VAULY \\
\hline $103 \mathrm{KW}$ & HEAD HOUSE \\
\hline $100 \mathrm{KW}$ & MAIN PUMP HOUSE \\
\hline $1701 \mathrm{~K}$ & BAOLE HOUSE. \\
\hline $1701 \mathrm{KA}$ & EXCLUSION AREA BADGE HOUSE \\
\hline $1702 \mathrm{~kW}$ & BADGE HOUST \\
\hline $1713 \mathrm{~kW}$ & WAREHOUSI \\
\hline $1714 \mathrm{KW}$ & OIL STOAAGE. \\
\hline $1717 \mathrm{~K}$ & MAINTENANCE \& IHANSPOHTATION \\
\hline $1720 \mathrm{~K}$ & OFFICES — TELEPHONE EXCHANGL \\
\hline $17: 1 \mathrm{~K}$ & UFFICE YRAILEA \\
\hline $1722 \mathrm{~K}$ & OFFICE TRAILER \\
\hline $105 \mathrm{KE}$ & REACTORFACILITY \\
\hline 1OY KE & WATER RETENIION BASIN \\
\hline $110 \times \mathrm{K}$ & IASESTORACIE \\
\hline $115 \mathrm{KE}$ & GAS RECIACULATION BUILDING \\
\hline $116 \mathrm{KE}$ & REACTOR STACK \\
\hline$\because 17 A E$ & EXHAUST AIR FILTER BUILDING \\
\hline $110 \mathrm{KE}$ & MAINTENANCE SHOP \\
\hline IEOKE & HEAT RECOVEAV FACILITY \\
\hline $165 \mathrm{KE}$ & POWEA CONIAOL BUILDING \\
\hline 186.A KE & OIL HOUSE \\
\hline IOS KE & OIL BUNKER \\
\hline $181 \mathrm{kE}$ & RIVER PUMFI STATION \\
\hline $103 \mathrm{KE}$ & CHLORINE VAUIT \\
\hline $103 \mathrm{KE}$ & HEAD NOUSE \\
\hline $1702 \mathrm{KE}$ & BAUGE HOUSE \\
\hline 1705 & EFLLUENY WATEA THEATMENY PILOI PLANI. \\
\hline $1708 \mathrm{KE}$ & WATEH STUDIES SEMIWOAKS FACIIITY \\
\hline 1708 KEA & WAYER STUUIES RE CIRCULATION BUII DING \\
\hline IJ1J KE & SHOP BUILDING \\
\hline $1713 \mathrm{KER}$ & WAREHOUSE \\
\hline $1714 \mathrm{KE}$ & OIL • PAINT BTOHAOE \\
\hline & $\begin{array}{l}\text { AADIOLOGICAL UNDEAGROUND SITES } \\
\text { (AETIRED) }\end{array}$ \\
\hline $110 k$ & ROLIO WASTE UUNIAL GROIINDS \\
\hline $110 k \cdot 1$ & EMEAOENCY CAIS \\
\hline $116 \mathrm{~K}-2$ & - MILE WASTE TRENCH \\
\hline $107 \mathrm{KE}$ & AE TENYICN DASIN TANKS \\
\hline $\begin{array}{l}\text { Pot KW } \\
116 \mathrm{KE}+1\end{array}$ & $\begin{array}{l}\text { AFTENTION DABIAA TANKS } \\
\text { IIS KE CAIB }\end{array}$ \\
\hline $116 \times k-1$ & $115 \times W$ CAIB \\
\hline $116 \mathrm{KE} \cdot 2$ & THOO KEA CAIB \\
\hline $110 \mathrm{nis}$ & 150 UUTRALL \\
\hline
\end{tabular}
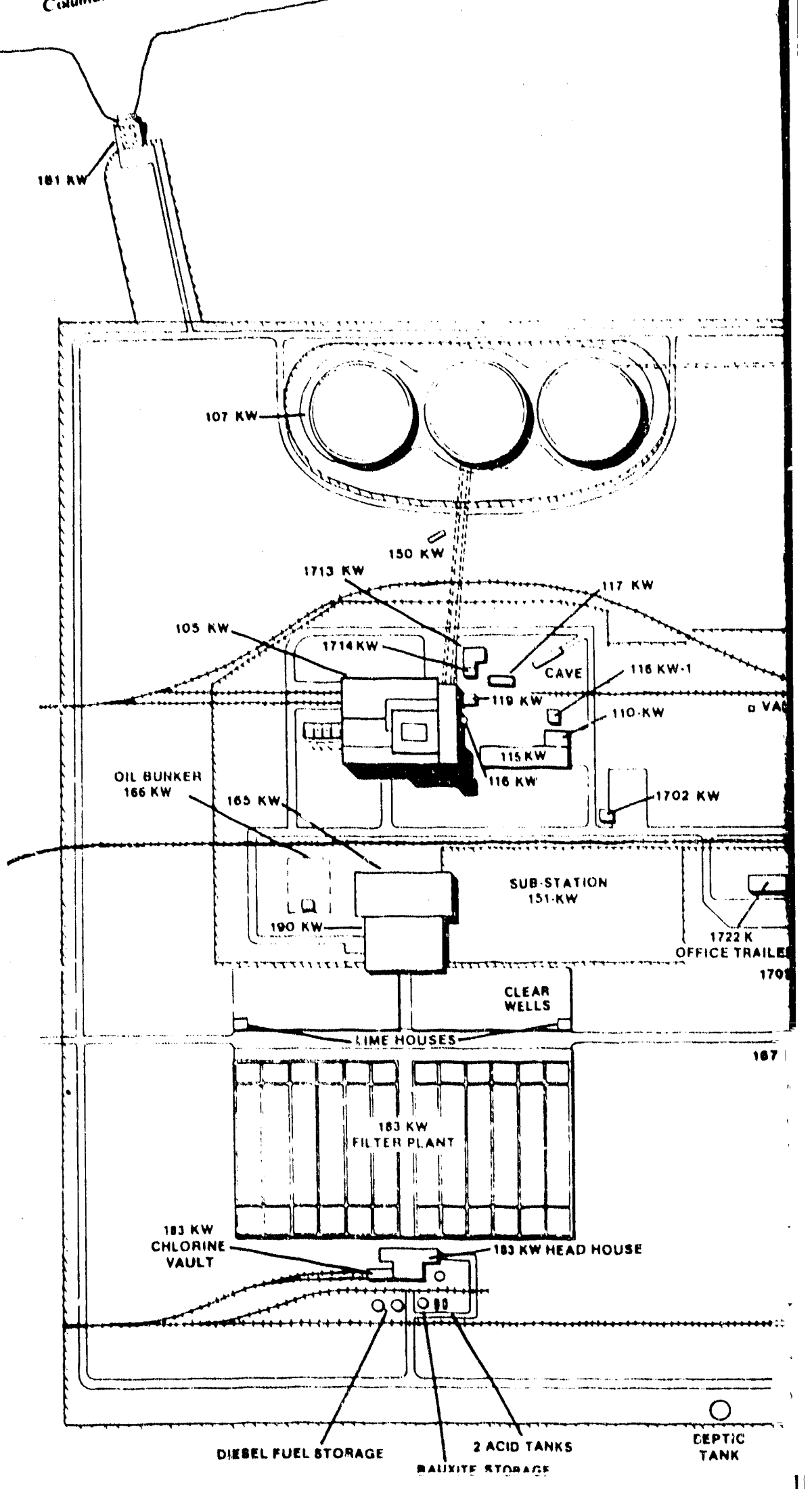


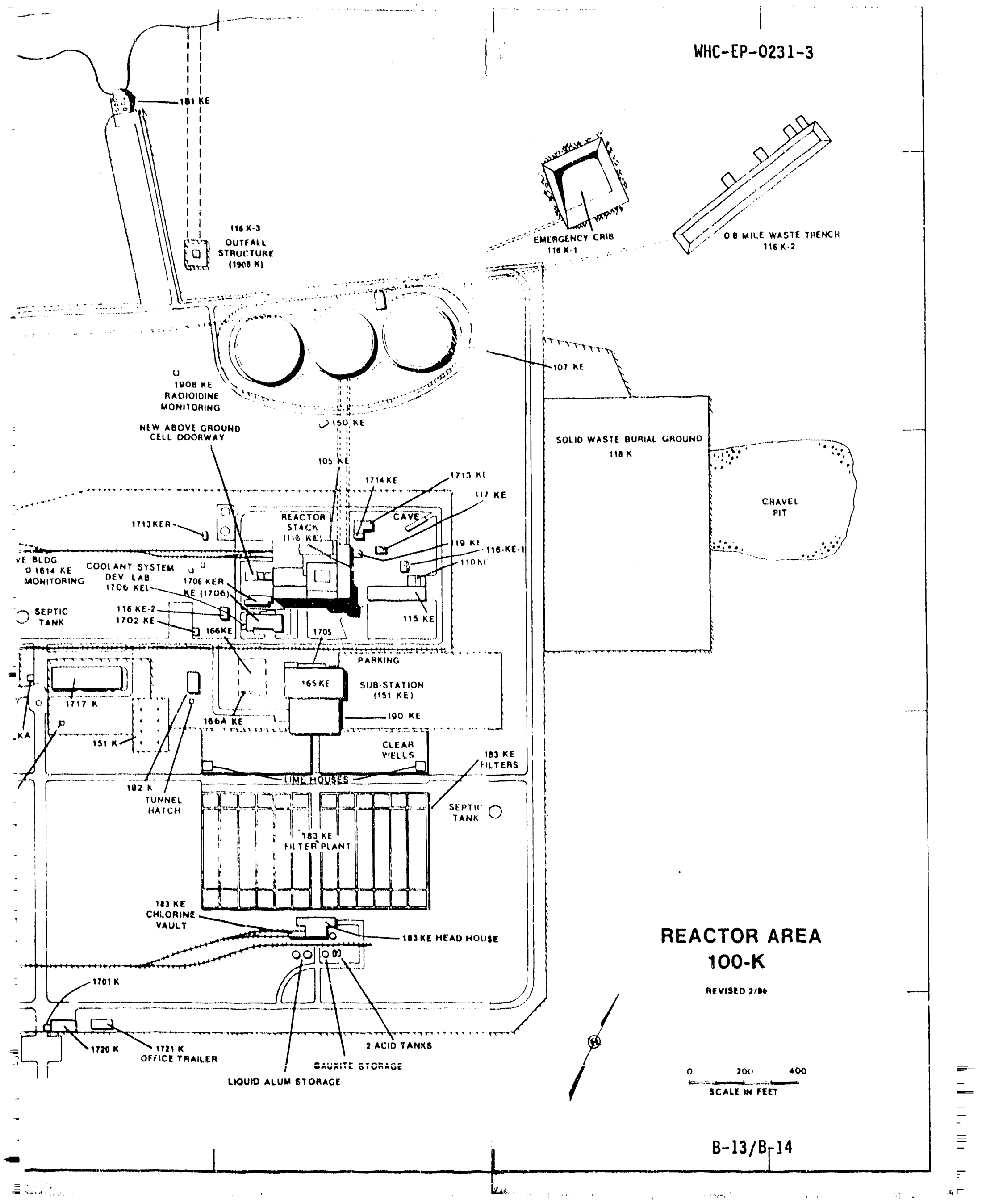




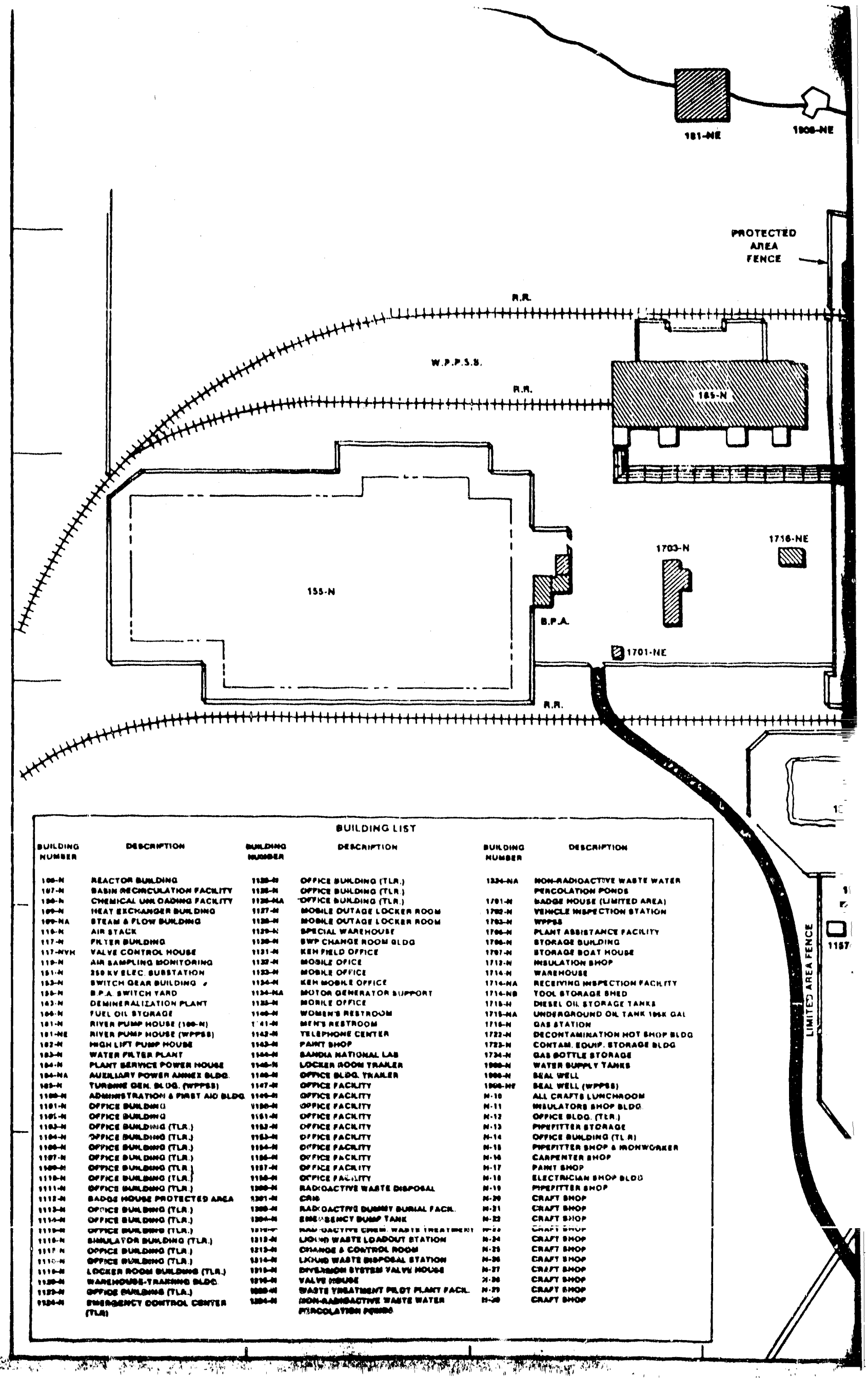




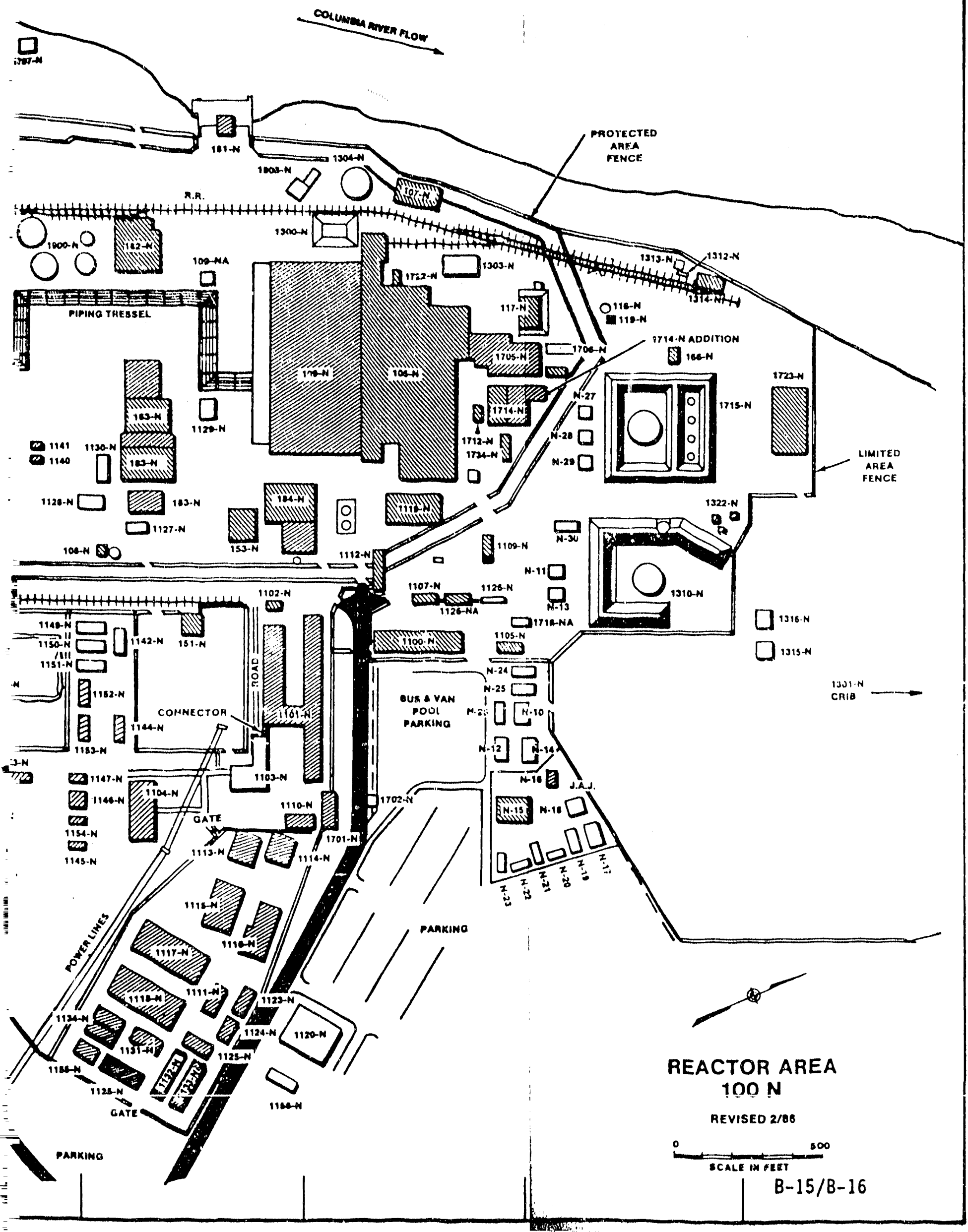


eunLirsaust

\begin{tabular}{|c|c|}
\hline 201-C & STRONTIUM SEMI WORKS \\
\hline $202 \cdot A$ & PUACX \\
\hline $207 \cdot A$ & METENTION BASIM \\
\hline $200-E$ & BNW CRITICAL MASS LAO \\
\hline $211 \cdot-A$ & CHEMICAL MAKE UP TANK FAAM \\
\hline $212-\lambda, 212-B$ & FISSHON PHOOUCTS, LOADOUT STATIIIA \\
\hline 215-c & GASER. ARATION BUILDING \\
\hline 216-C & QAS HALPAAATION BUILDINC \\
\hline $2111 \cdot t-4,5,5 \wedge, 2,9$ & DURIAL GROUNDS \\
\hline 218.E.10 & GUAIAL GROUND \\
\hline 218-E.128 & - UAJAL GAOUND \\
\hline 221. & SEPARATION GUILDING \\
\hline $211.3 \%$ & CONOENSACF EFILUTNY WISCHAROE FAEILITY \\
\hline 222.6 & OFFICE BLILUINO \\
\hline $2 \cdot 0 \cdot n$ & STOHACBE BCIIL DIVA \\
\hline 225.8 & INCAPSULATIOS MUIIININA \\
\hline $241 \cdot 4 x$ & WASIE STORAGE IANK I $\cdots$ 'A \\
\hline $241 \cdot$ An & TANE FAHM \\
\hline $241 . A Y$ & YANK + A.RM \\
\hline $241.8 \mathrm{Y}$ & TANK FARM \\
\hline $241 . A W$ & WASTE SYORAGE MAN'I I HA.M \\
\hline $241 \cdot \lambda 2$ & WASTE STOAAGE TANE IAI'AI \\
\hline $241 . \mathrm{C}$ & WASTE STOAAGE TANK FAHM \\
\hline $242 \cdot A$ & EVAPORATION BUILUING \\
\hline $244 \cdot A, A R, B \times A$ & VAULTS \\
\hline 271.3 & SEAVICE BIILLDINO \\
\hline 271.CA & CONYROL HOUSE \\
\hline $272 \cdot B C, E$ & SHOPs \\
\hline 273-E. & ABANDONED \\
\hline 274-E & MAINTENANCE BHOP \\
\hline 275-E & CAAPENTER'S PAINT SHOP \\
\hline 27S-EA & WAREHOUSE \\
\hline 278-8 & SOLVENT STOAAOE \\
\hline $282 . \mathrm{E}$ & AESERVOIA \\
\hline $283 \cdot E$ & FILTER PL.ANT \\
\hline 284.E & $\begin{array}{l}\text { POWEA HOUSE } \\
\text { FAN HOUSE \& STACK }\end{array}$ \\
\hline 291.4 & $\begin{array}{l}\text { FAN HOUSE A STACK } \\
\text { SAND FILTERS }\end{array}$ \\
\hline $\begin{array}{l}291.8 \\
291.8 \mathrm{C}, \mathrm{BO}, \mathrm{BF}\end{array}$ & $\begin{array}{l}\text { SAND FILTERS } \\
\text { NEW FILTEHS }\end{array}$ \\
\hline 201-8E & STACK \\
\hline $2810-8 \mathrm{G}$ & STACK AIN BAMPLER \\
\hline $281 \cdot C, 292 \cdot \mathrm{e}$ & VENTILATINGE STAZKS \\
\hline $293 . A$ & OFF GAS TREATMENT ACID HECOVERY BLDO. \\
\hline $2101 \cdot M$ & SHARE PARTS ANO ELECTRICAL WAHEHOUSE \\
\hline $2400 \cdot \varepsilon$ & DRY MATEHIAL HANOLING FACILITY \\
\hline 2701-M & STORAGE BUILDING \\
\hline 2Y03-E & CHEMICAL TESTING FACILITY \\
\hline 2rosc.e. & OFFICE HUILDINO \\
\hline $2707 . \mathrm{k}$ & CHANGE HOUSE \\
\hline $2709 \cdot E$ & VACANT \\
\hline $2713-E$ & OFFICL BUILDINO \\
\hline 2715.E: & OIL W HAINT STOHAGE BUILDING \\
\hline 2715.48 & INHLAMGABLE STOF:AGE \& PAINI SPRAY BLOG. \\
\hline 2716.8 & STOHAOE \\
\hline $2116 . \mathrm{E}$ & CAITICAL. MASS FISSILE STOAAGE BLUG. \\
\hline $2714-\mathrm{E}$ & FIAST AIO STATION \\
\hline $27 \div 9 \cdot \mathrm{E}$ & YAC.NNT \\
\hline $2721 \cdot E$ & PATRUL HEAUQUARTEAS \\
\hline $2721.6 \mathrm{~A}$ & HELICOPTER FACILITY \\
\hline 2725 & OFFICF DUII HiNG \\
\hline $2727 \cdot E$ & OFFICE DUIL.DING \\
\hline $2750-E$ & OFFICE DUILDING \\
\hline 27s, E. & OFFICE BUILUING \\
\hline 2752.E & OFFICE UUILDINO \\
\hline $2 \gamma \leqslant 3 \cdot E$ & CFFICF PUILDING \\
\hline
\end{tabular}

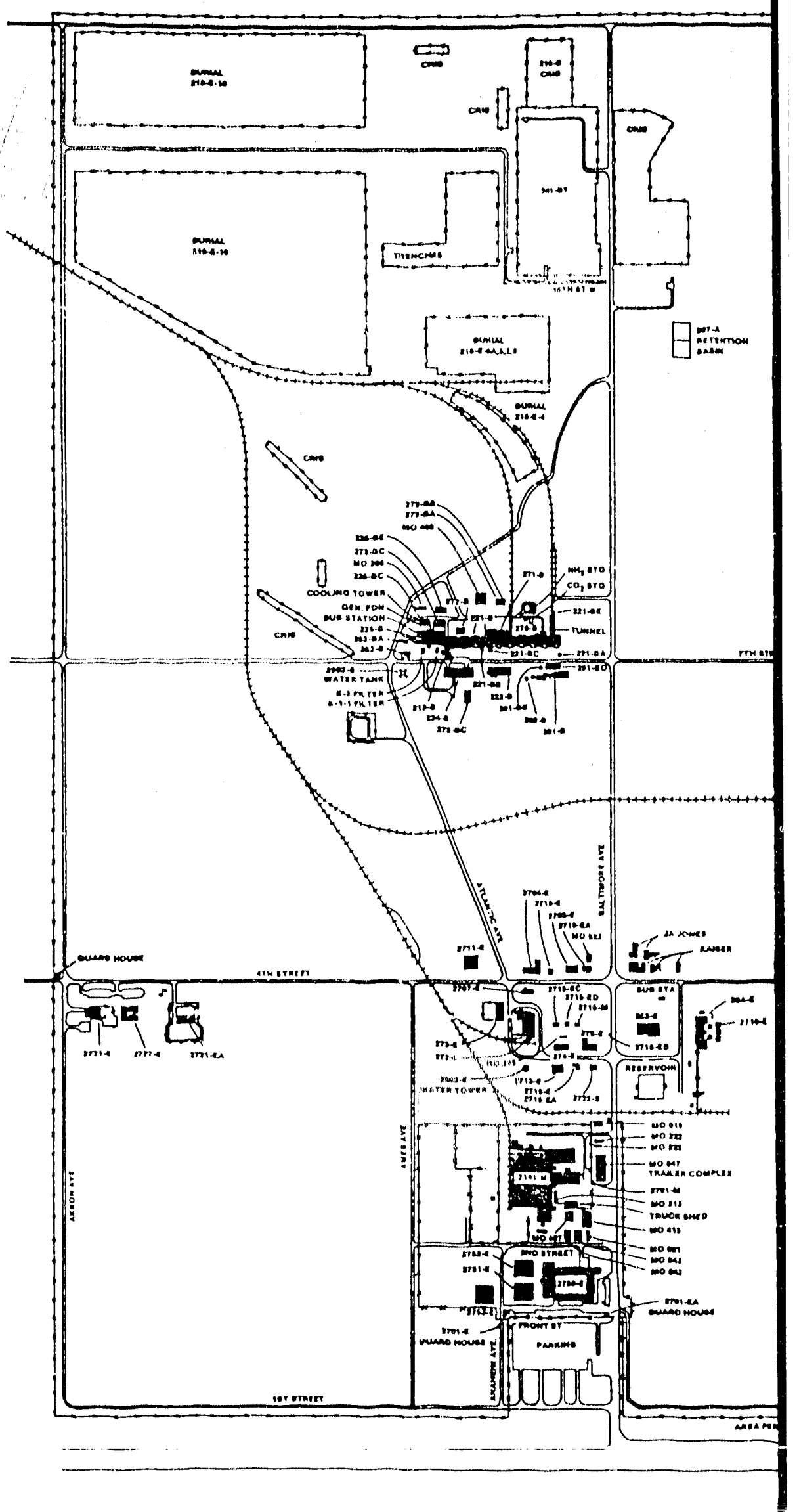




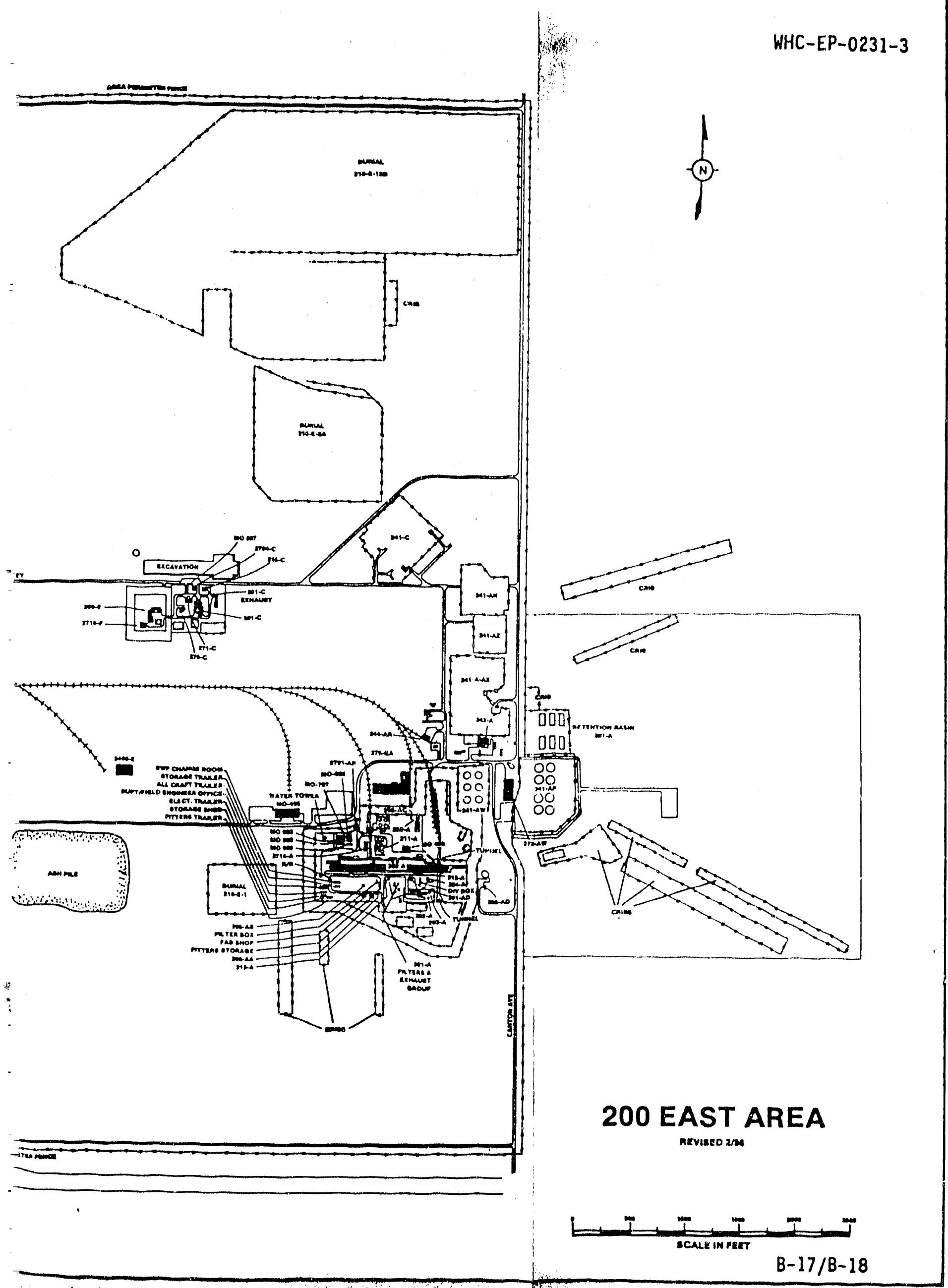

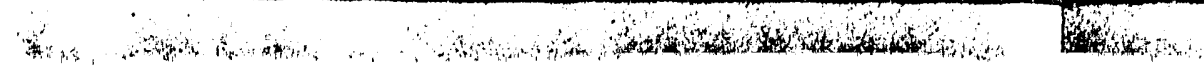




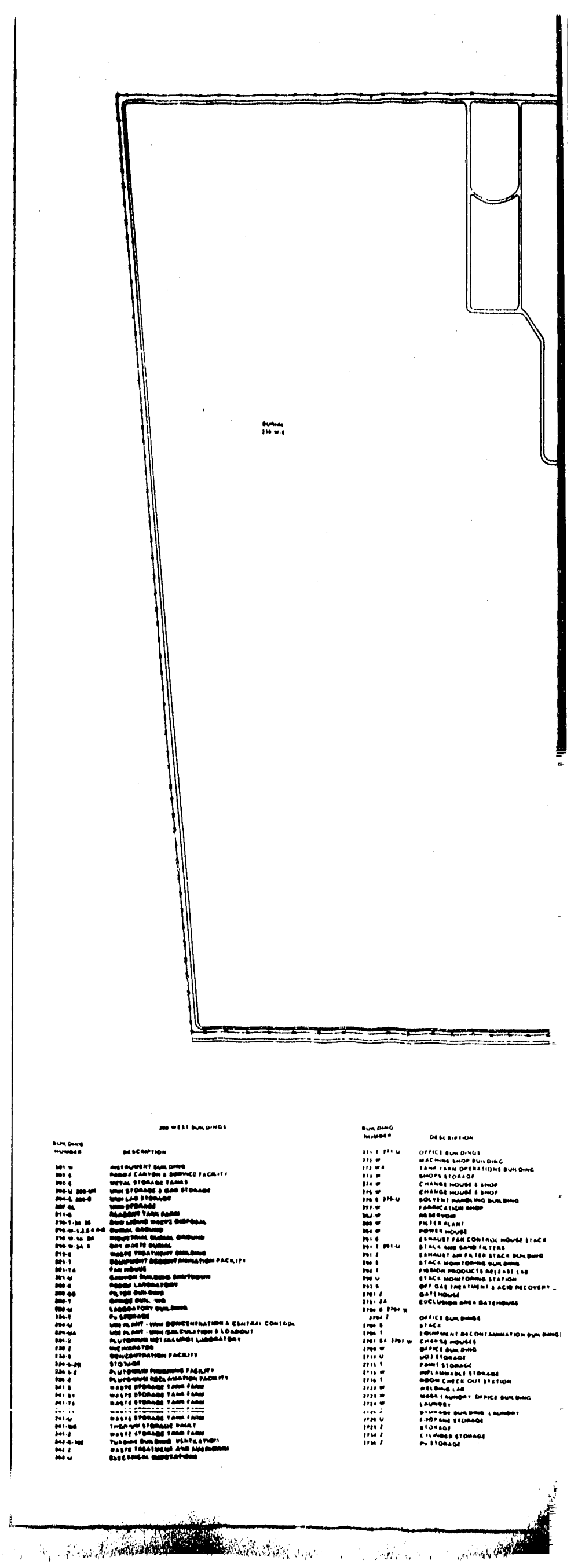




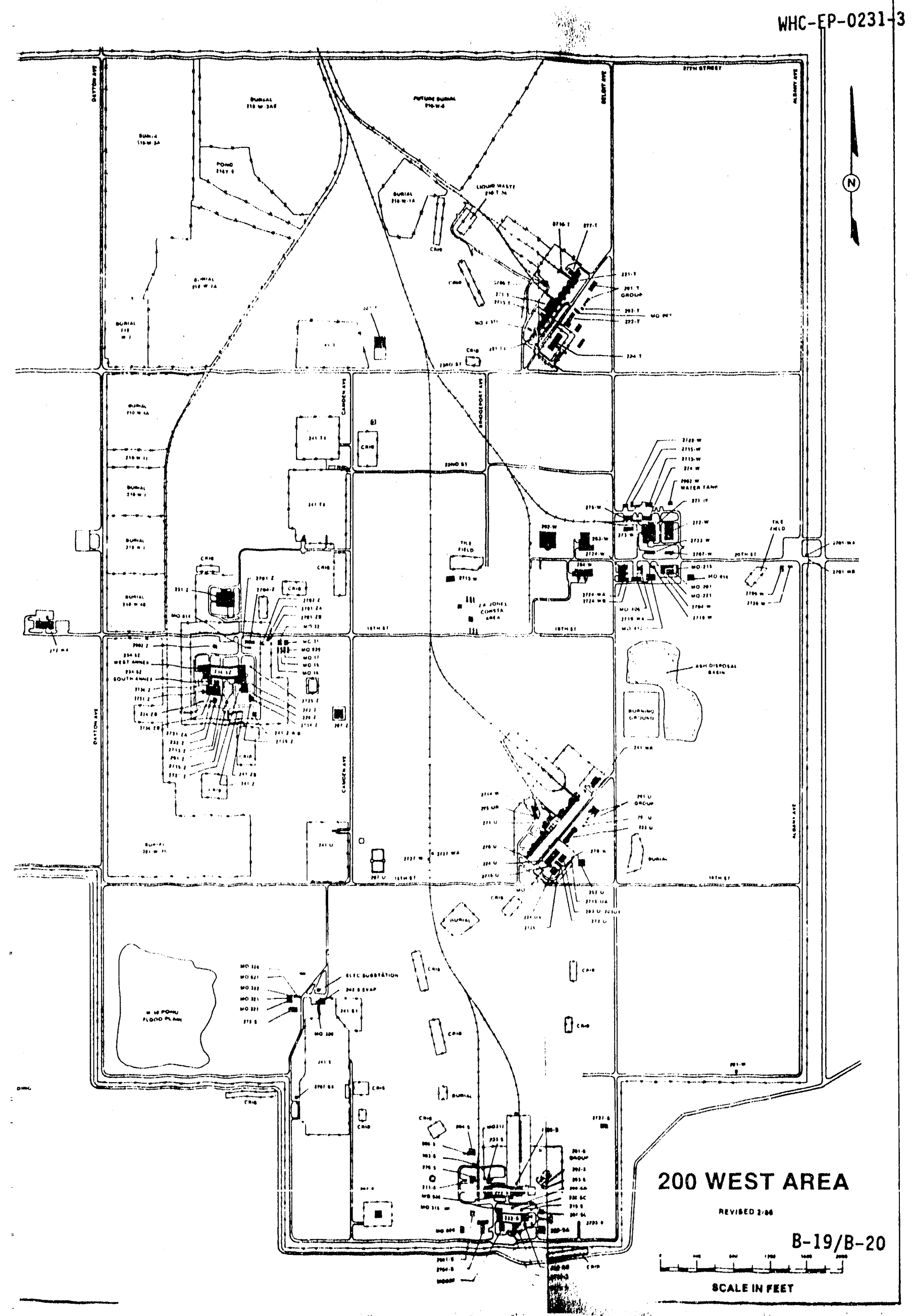




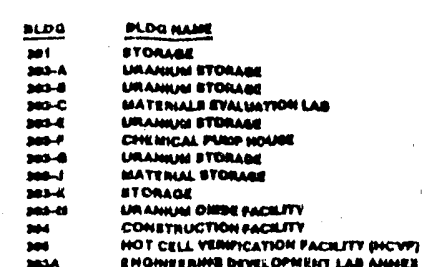

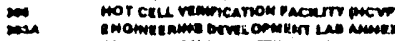

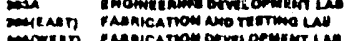

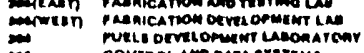

iil cowrnot vas

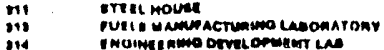

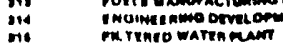

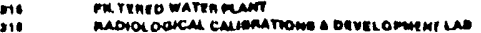

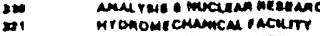

the

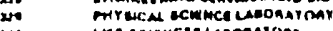

indecremcle lasomation

wis malledine

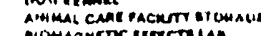

pi: momamerme

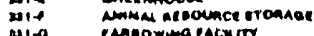

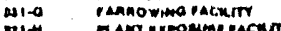

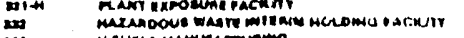

Movice

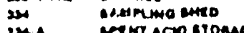

20. Ment acm eromace

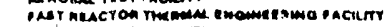

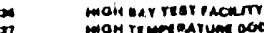

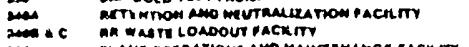

matroma

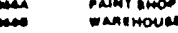

Mack inomace

are acmenaron cueritation

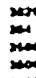

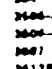

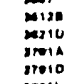

ming

(rid

mive

ind

ind

ind

molc

ind

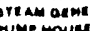

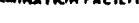

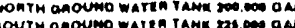

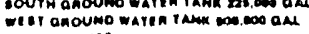

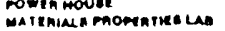

anevice watrop

iurnoencr aenenaton amo conthol

amiorncivacano onartom

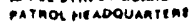

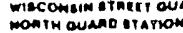

then

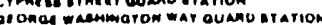

orrce:

然

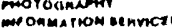

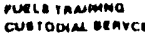

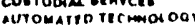

momatrow cenvices

cronace isan

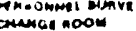

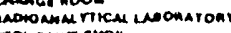

ime citarion

a ox eromace

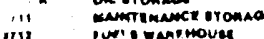

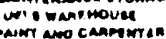

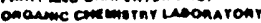

ironace

croancer

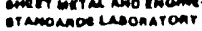

\section{merourt stomace}

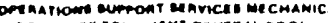

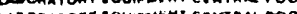

momaroury

cromage (a)

comate sumbino

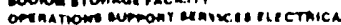

coupvrra rackirst

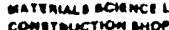

combinucriom ato or

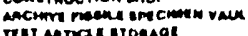

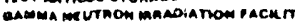

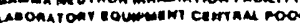

romaces

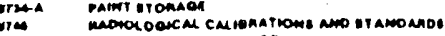

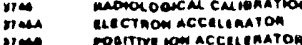

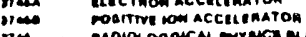

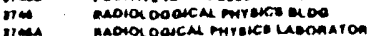

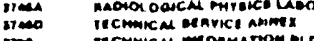

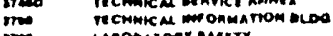

choobatont ewertr

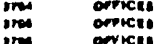

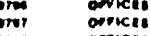

im

im

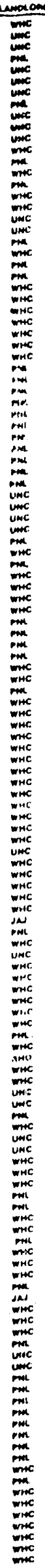

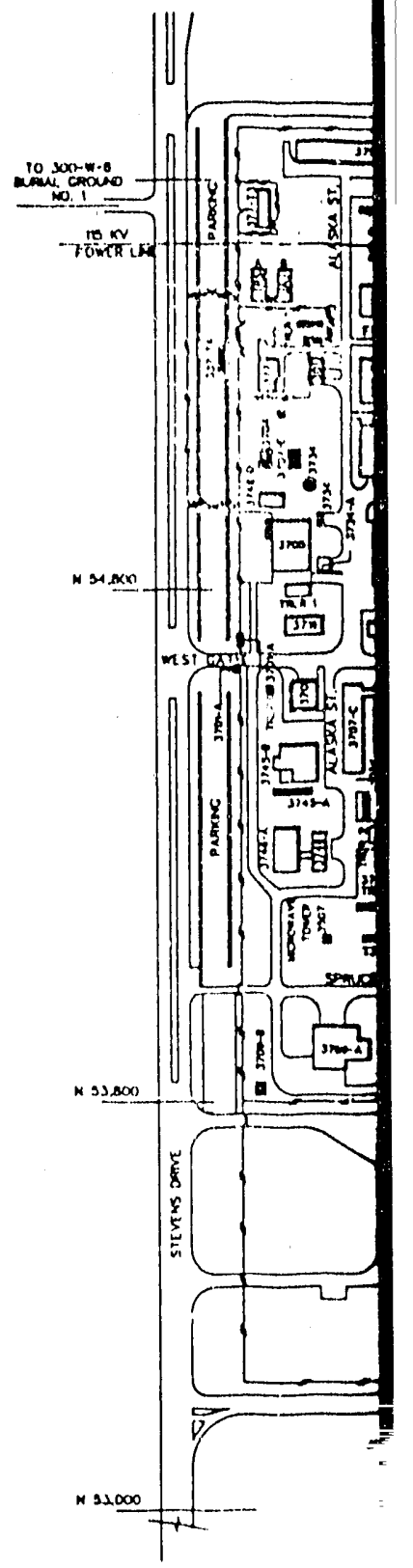




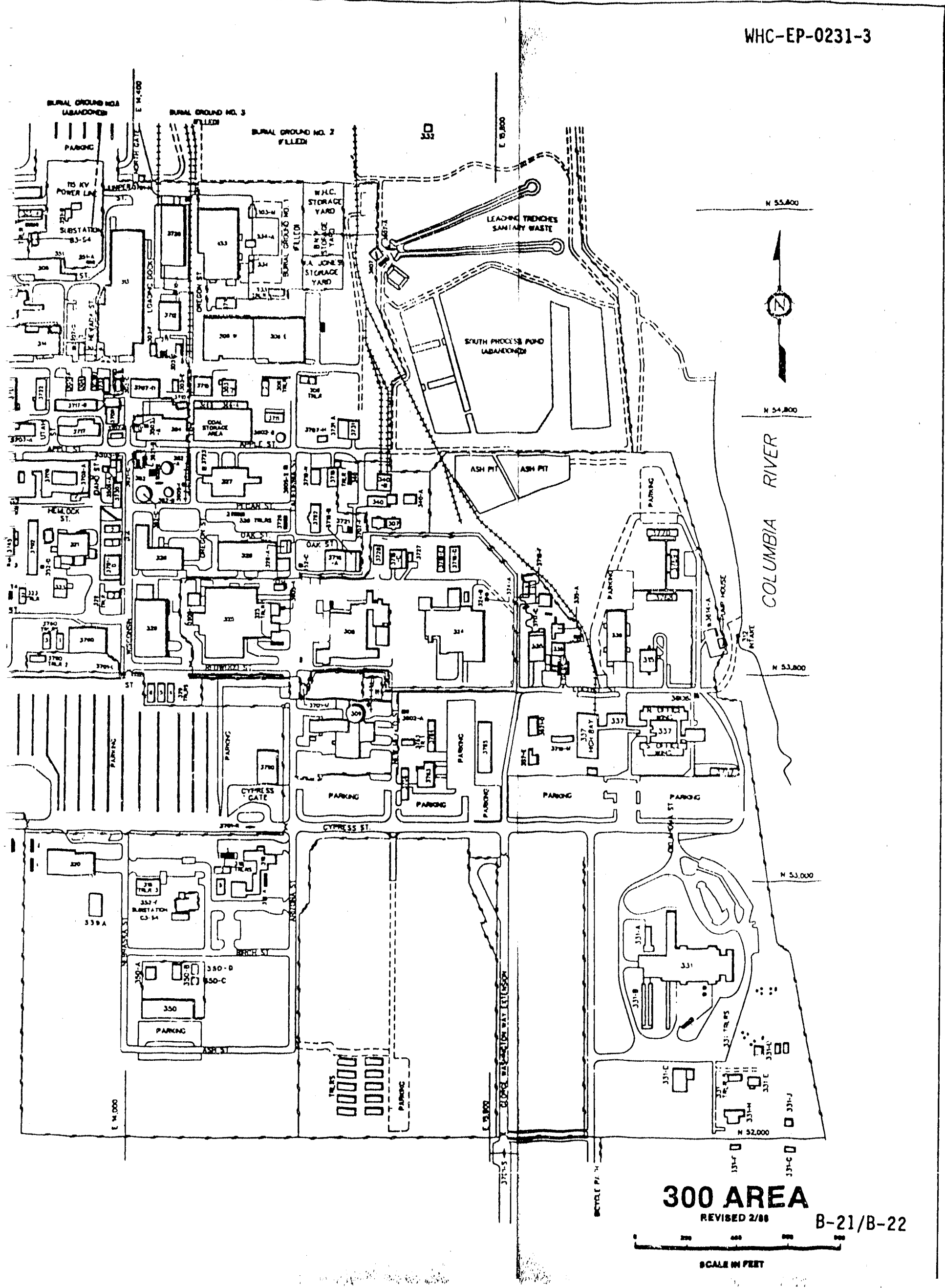



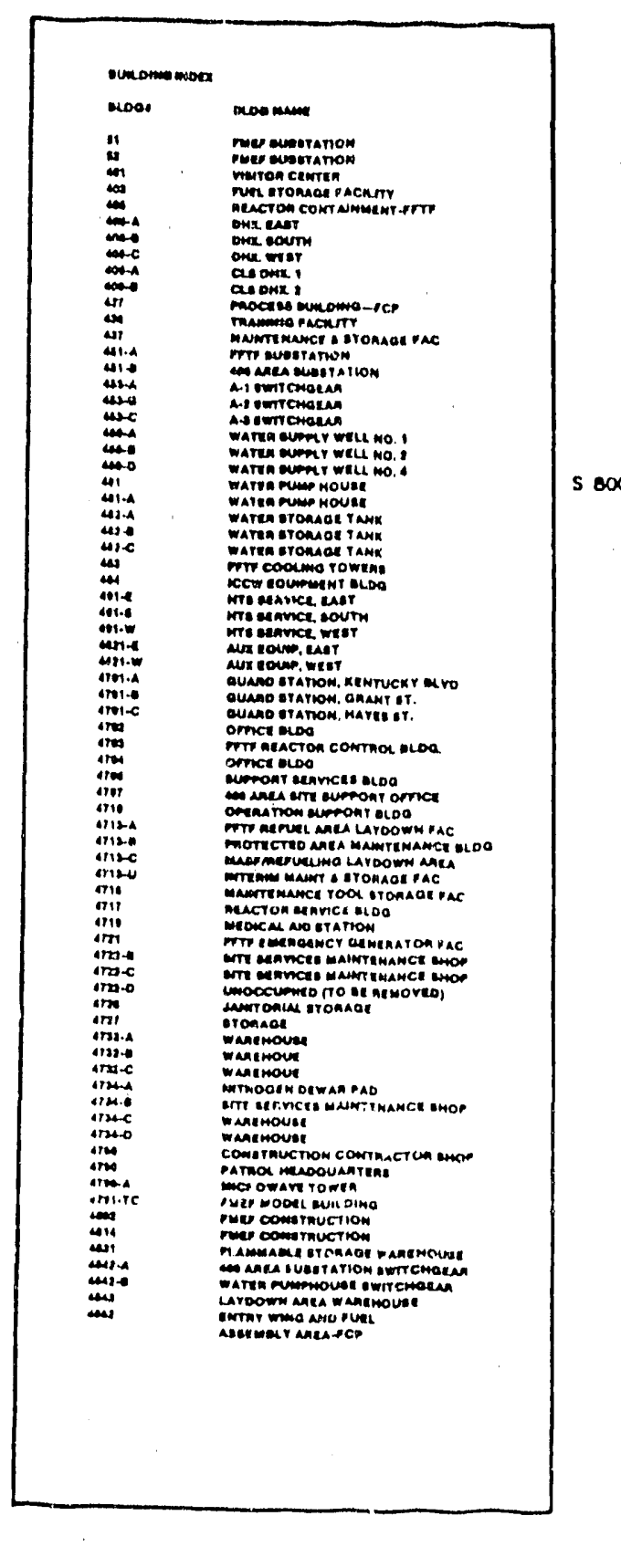


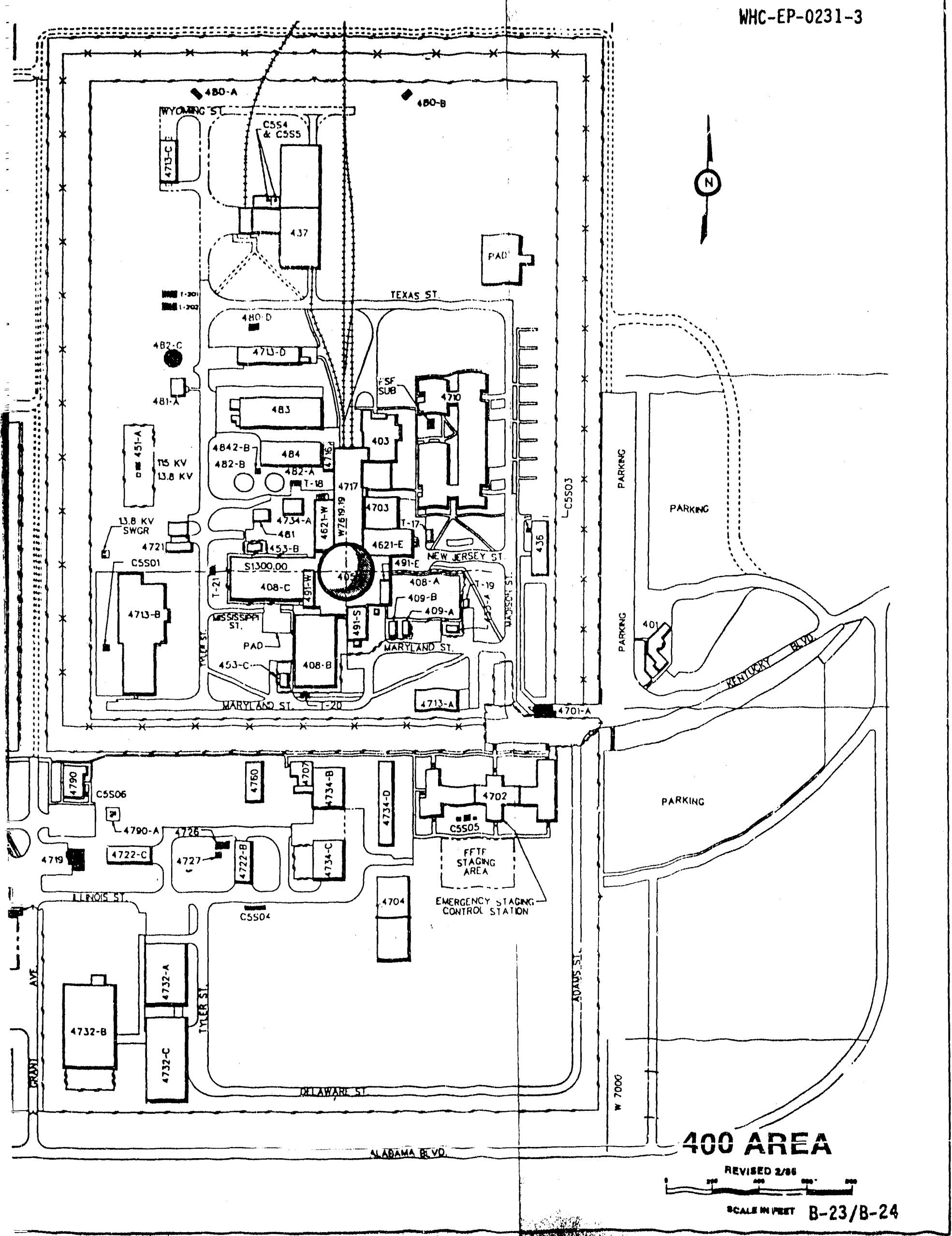




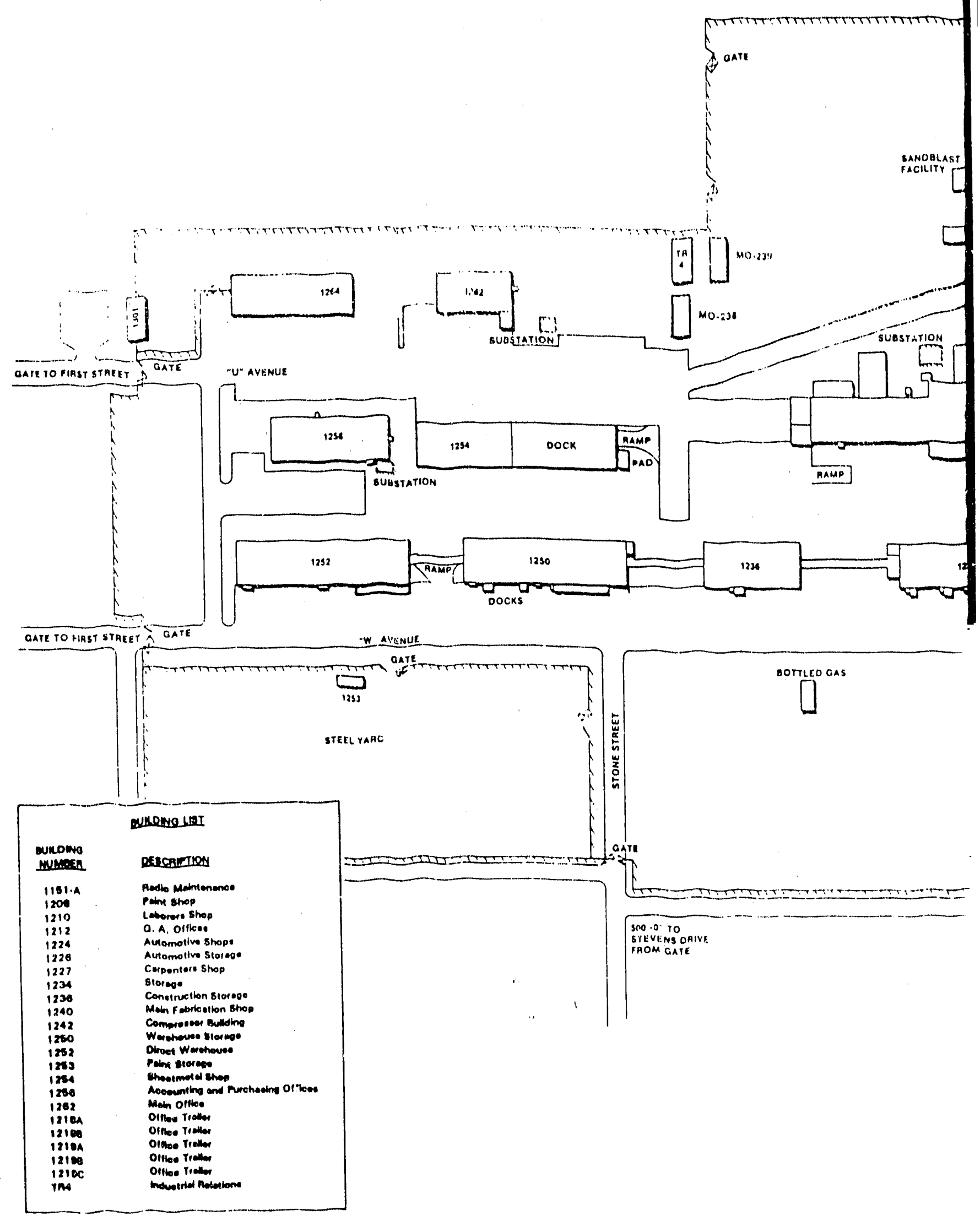




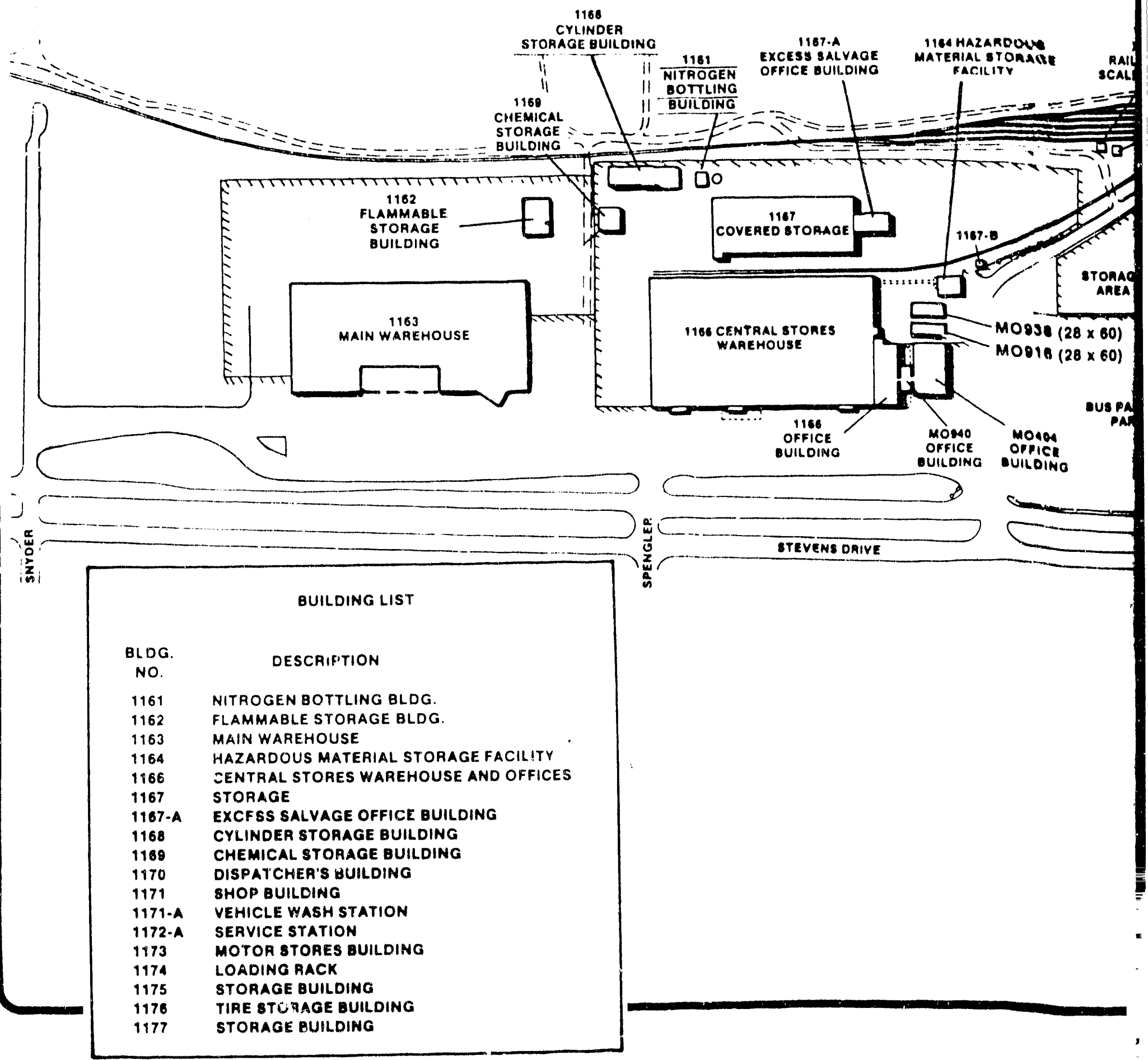




\begin{tabular}{|c|c|}
\hline & BUILDING LIST \\
\hline $\begin{array}{l}\text { BLDG. } \\
\text { NUMBER }\end{array}$ & DESCRIFTION \\
\hline $701 \mathrm{~A}$ & ELECTRICIANS SHOP \\
\hline 703 & DOE OFFICE BUILDING \\
\hline 712 & RECORDS CENTER \\
\hline 747 & $\begin{array}{l}\text { ENVIRONMENTAL HEALTH SCIENCES } \\
\text { LAB/FILTER TEST FACILITY (HEHF) }\end{array}$ \\
\hline $747 \mathrm{~A}$ & WHOLE BOOY OUNTEA (PNL) \\
\hline 747A/T1 & OFFICE TAAILEA \\
\hline 7478 & OFFICE ANNEX (HEMF) \\
\hline 748 & $\begin{array}{l}\text { EMERGENCY DECONTAMINATION } \\
\text { FACILITY (MEHF) }\end{array}$ \\
\hline
\end{tabular}

\section{AREA}

AEVISED 2/86

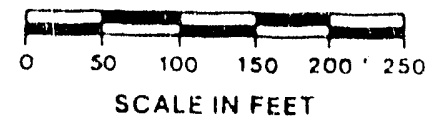

[.... DOE PROPERTY
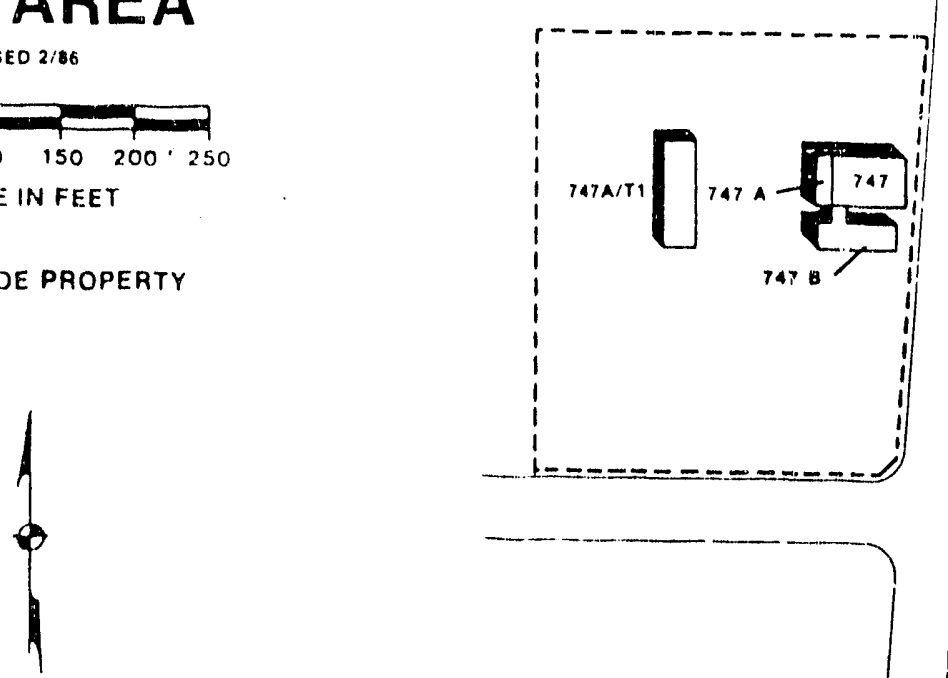


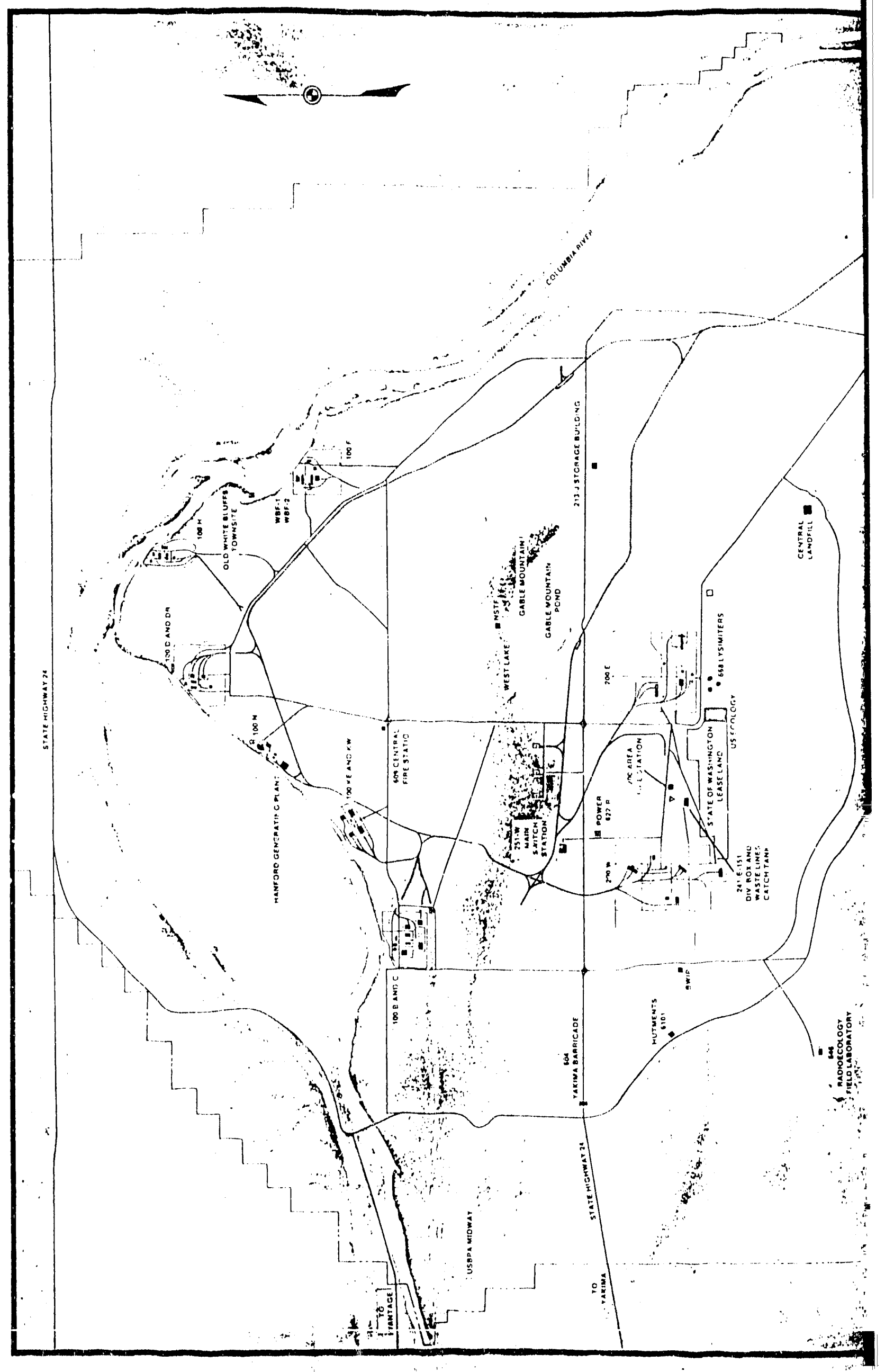




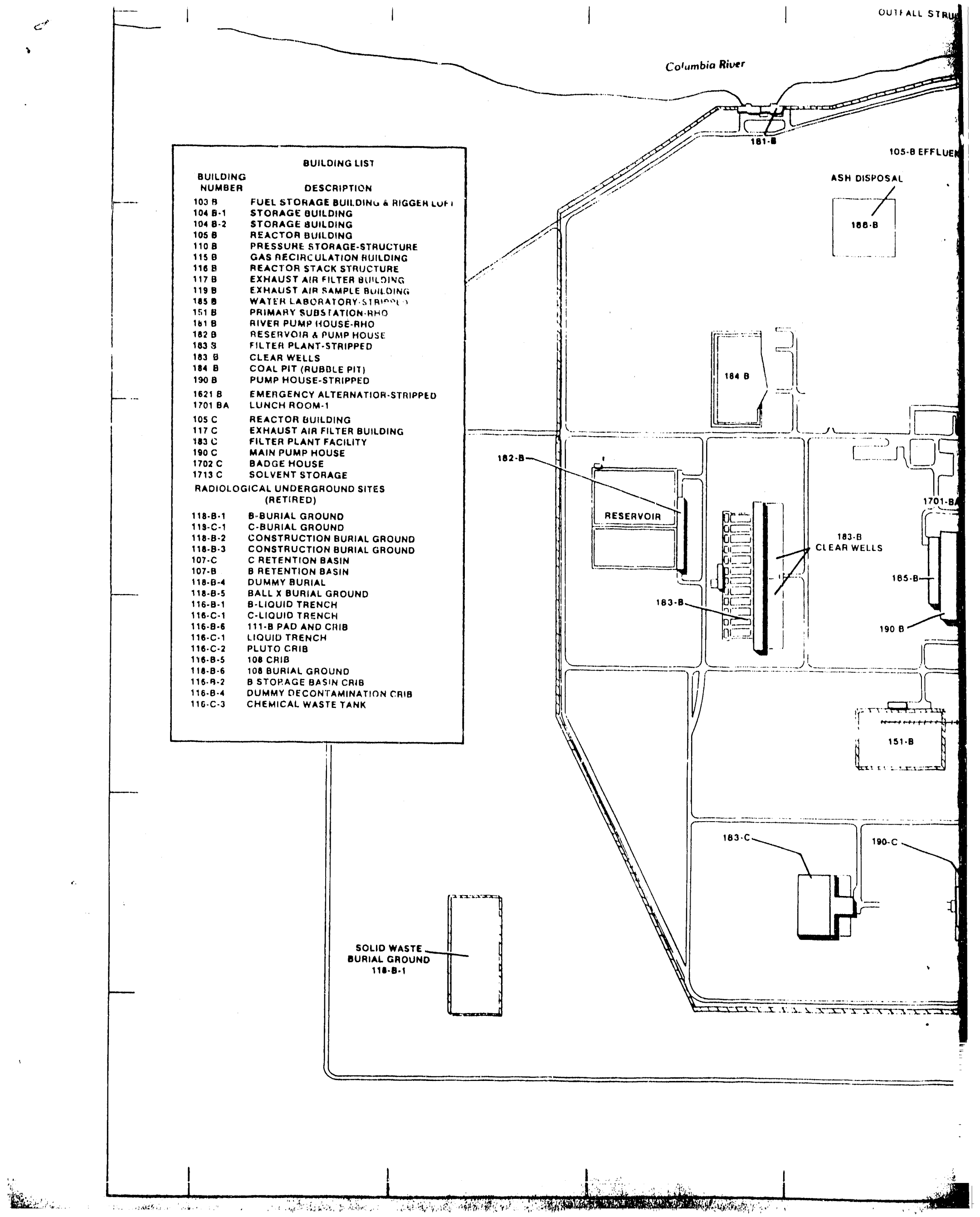




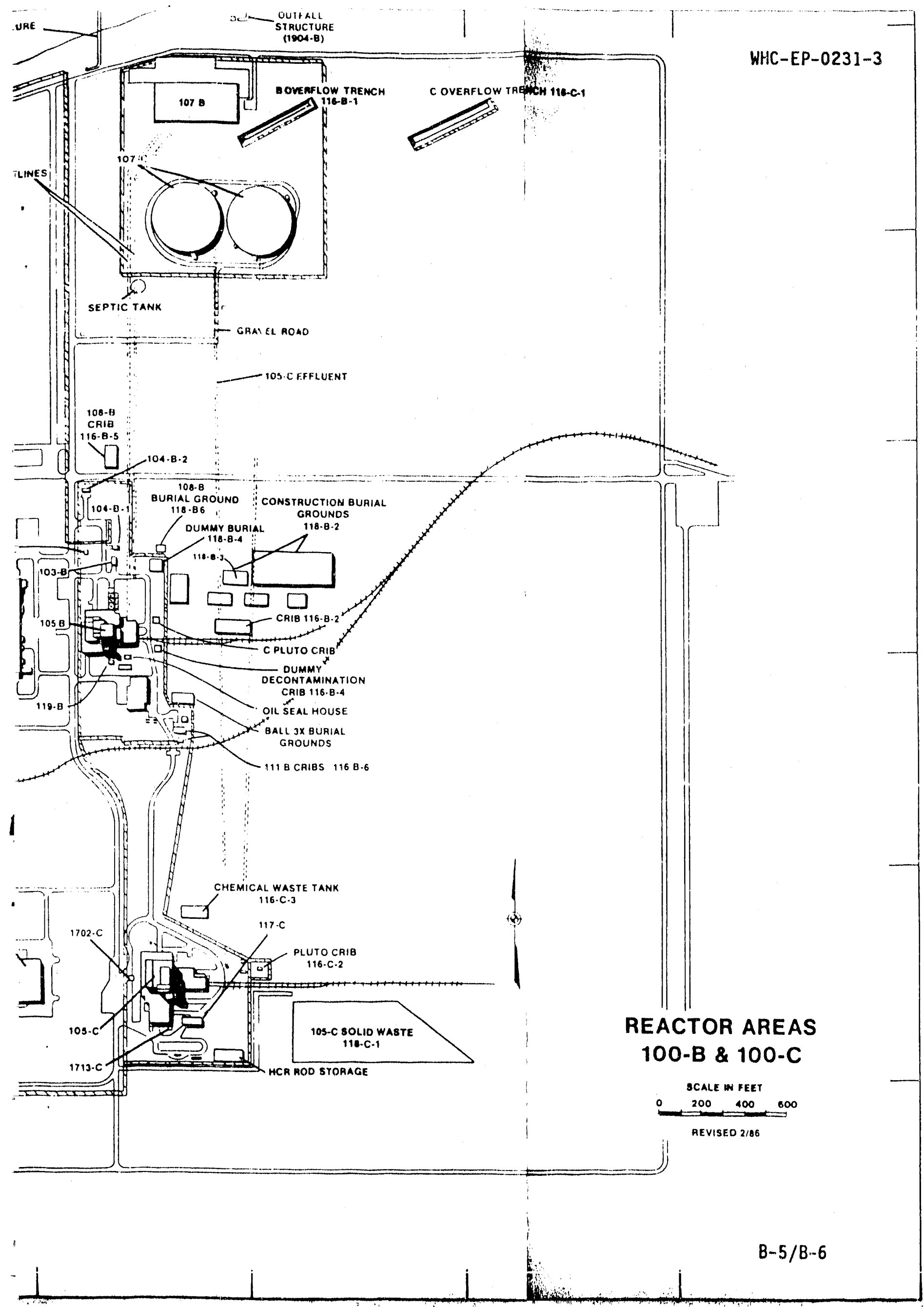




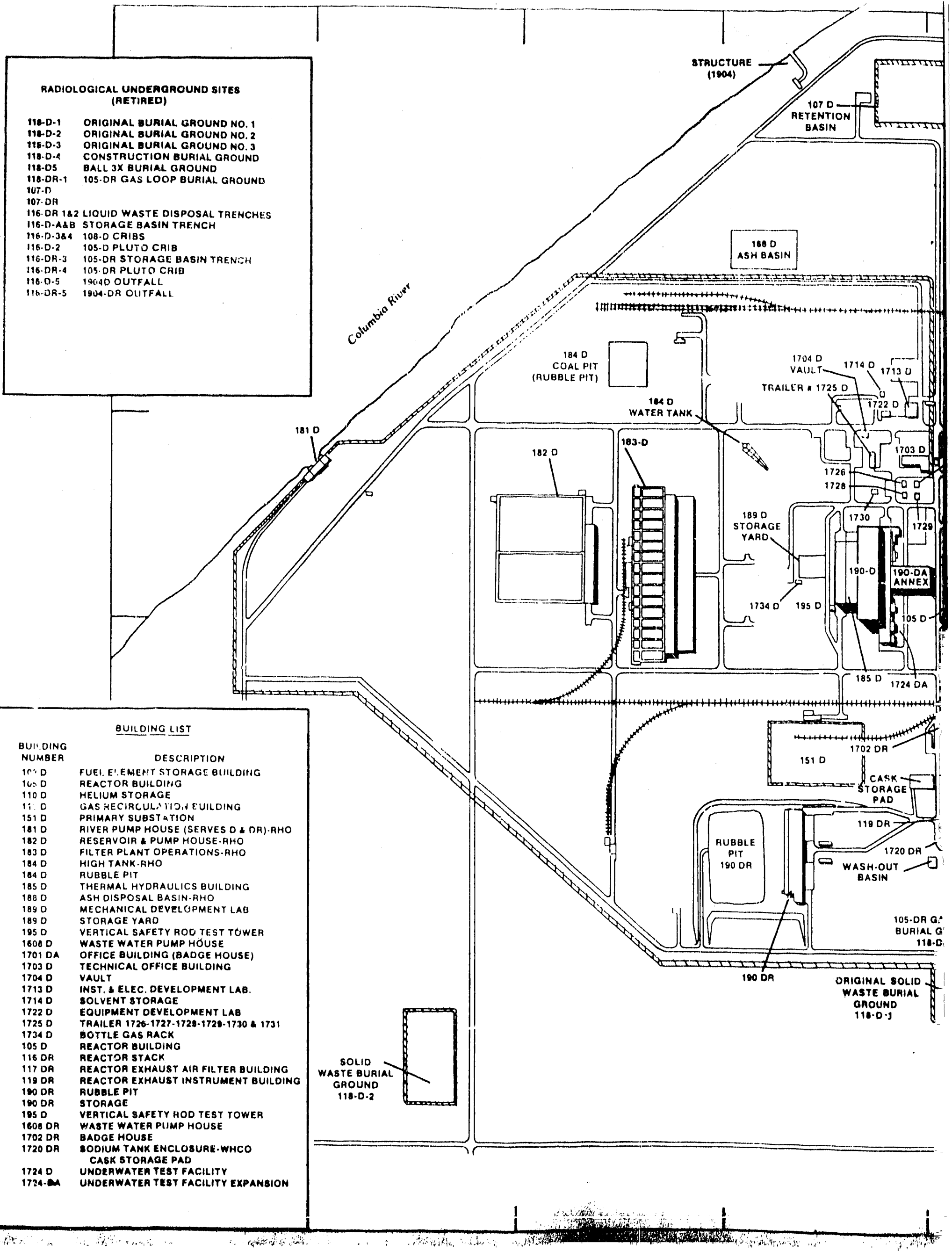




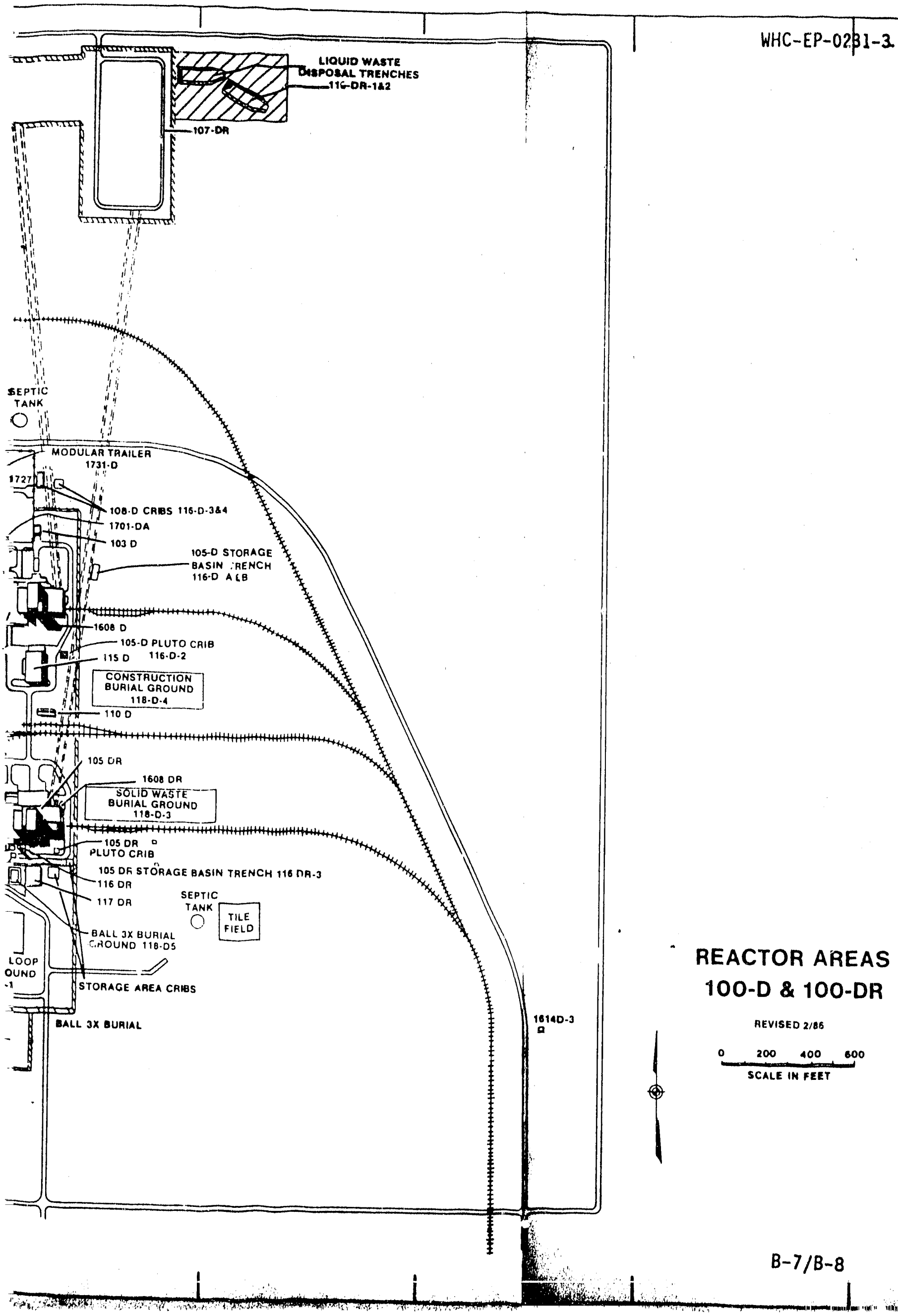


WHC-EP-0231-3

\section{APPENDIX C}

LONG-RANGE COST/SCHEDULE PROJECTION 
Table 1. Hanford Decommissioning Baseline Long-Range Projection. (\$000) (sheet 1 of 7 )

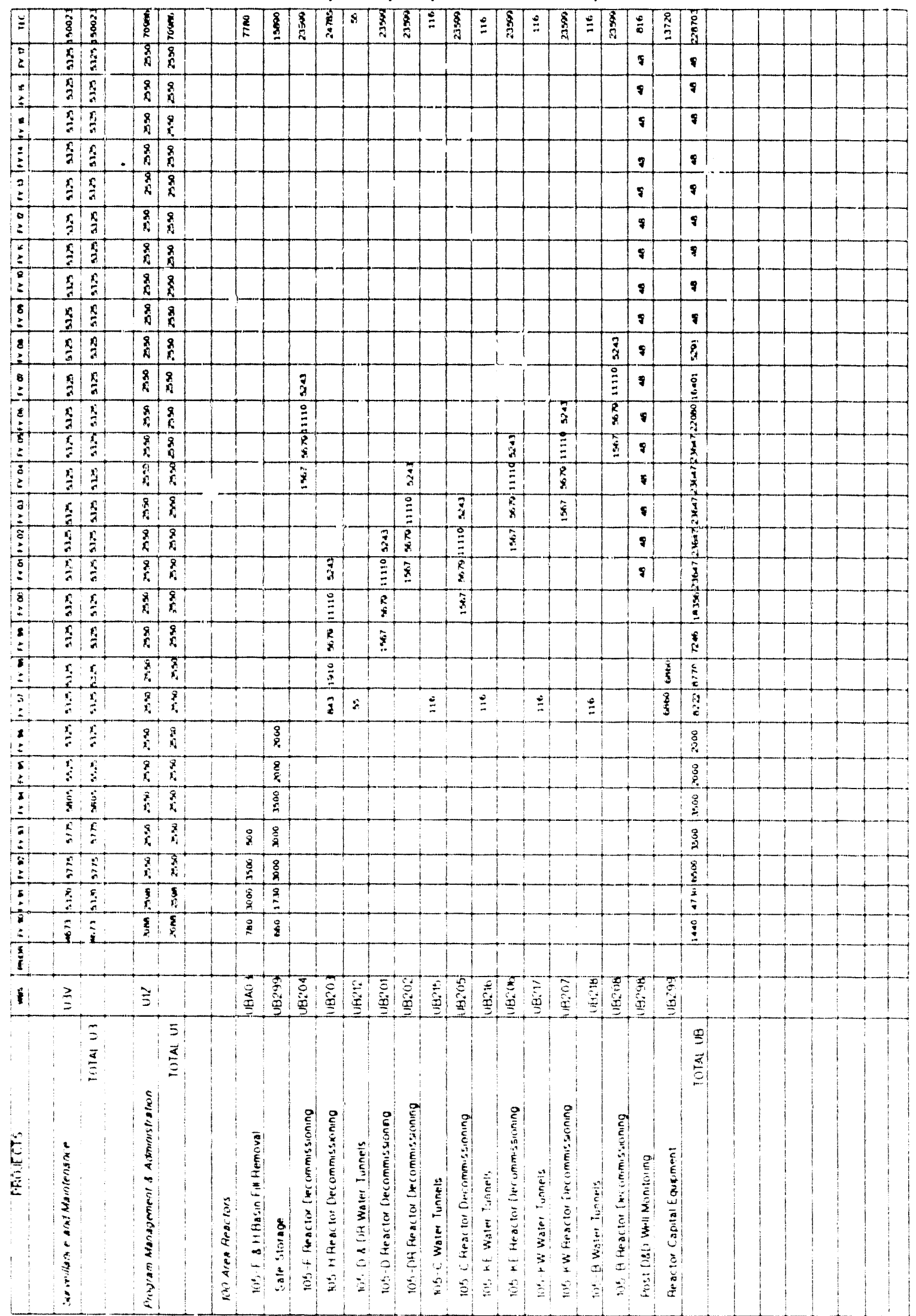


Table 1. Hanford Decommissioning Baseline Long-Range Projection. (\$000) (sheet 2 of 7 )

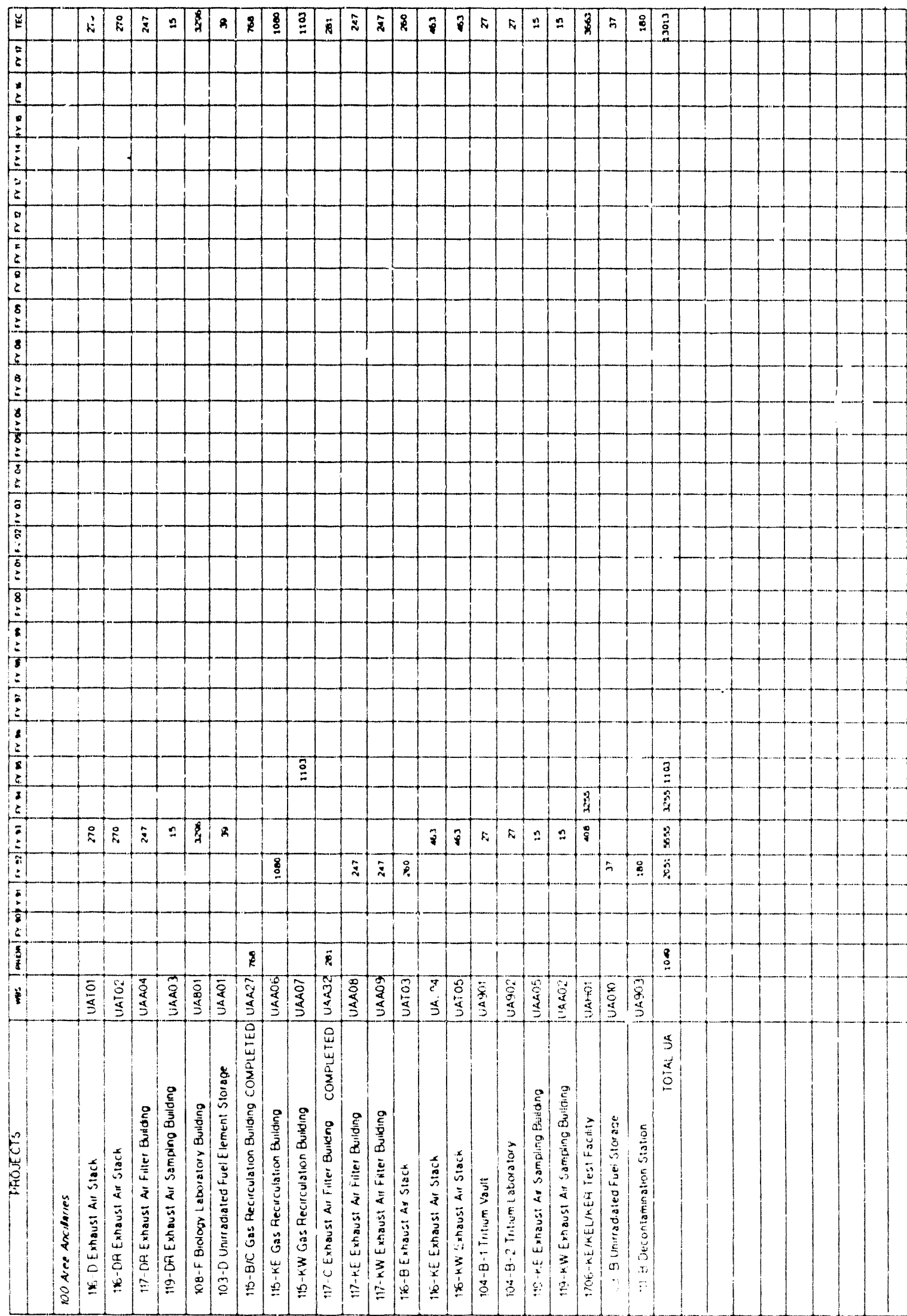


Table 1. Hanford Decommissioning Baseline Long-Range Projection. (\$000) (sheet 3 of 7 )

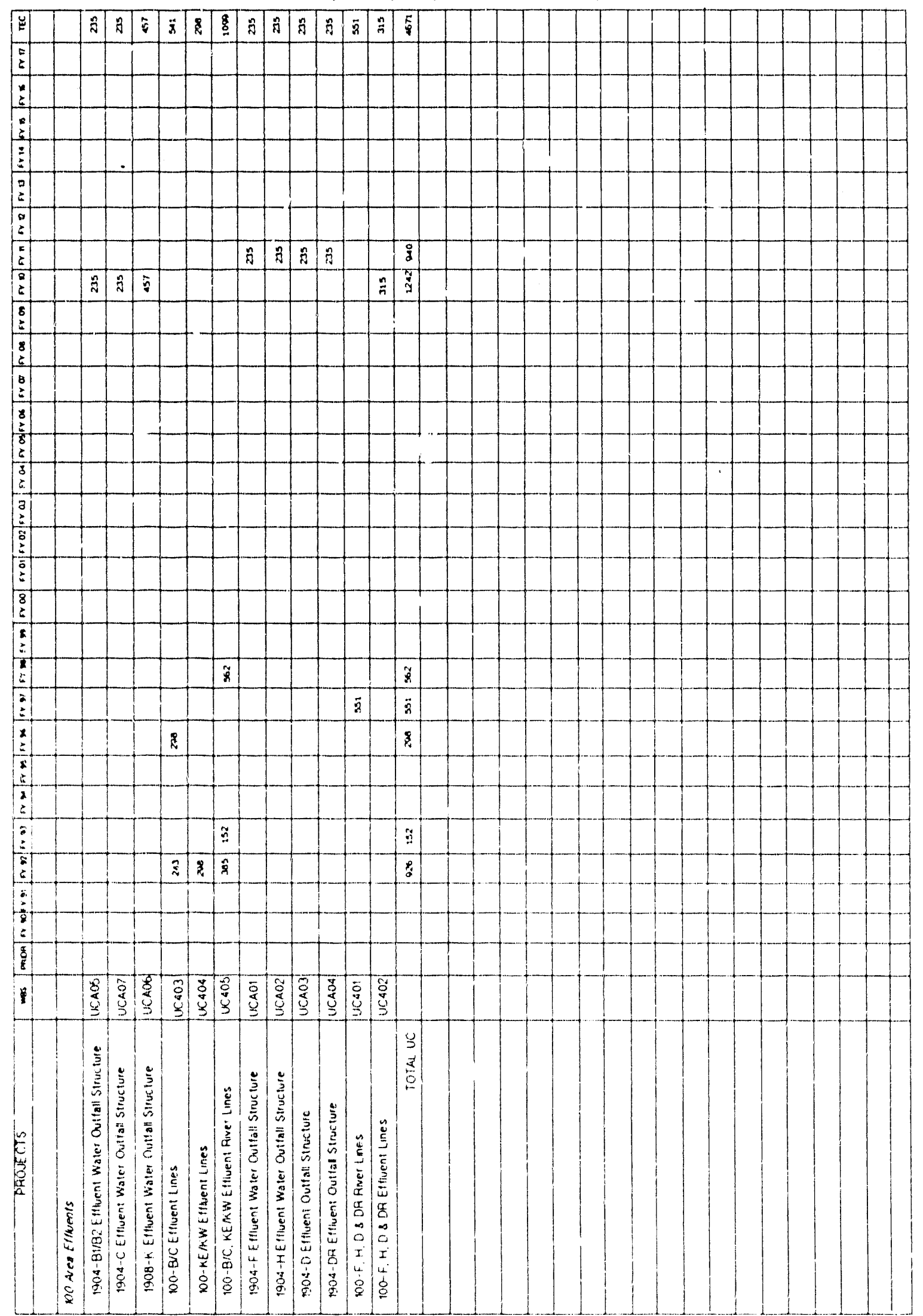


Table 1. Hanford Decommissioning Base? ine Long-Range Projection. (\$000) (sheet 4 of 7 )

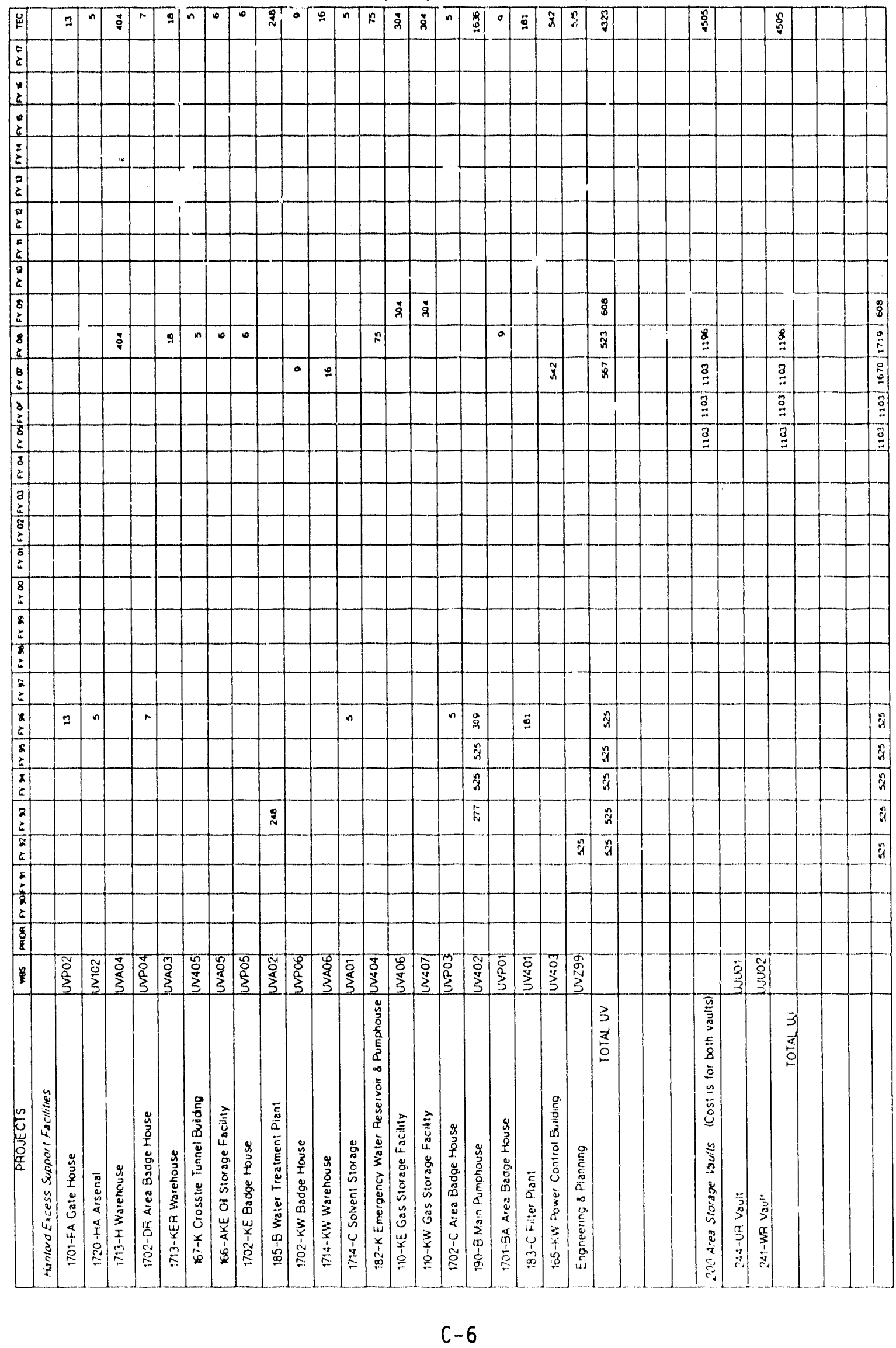


Table 1. Hanford Decommissioning Basel ine Long-Range Projection. . $(\$ 000)$ (sheet 5 of 7 )

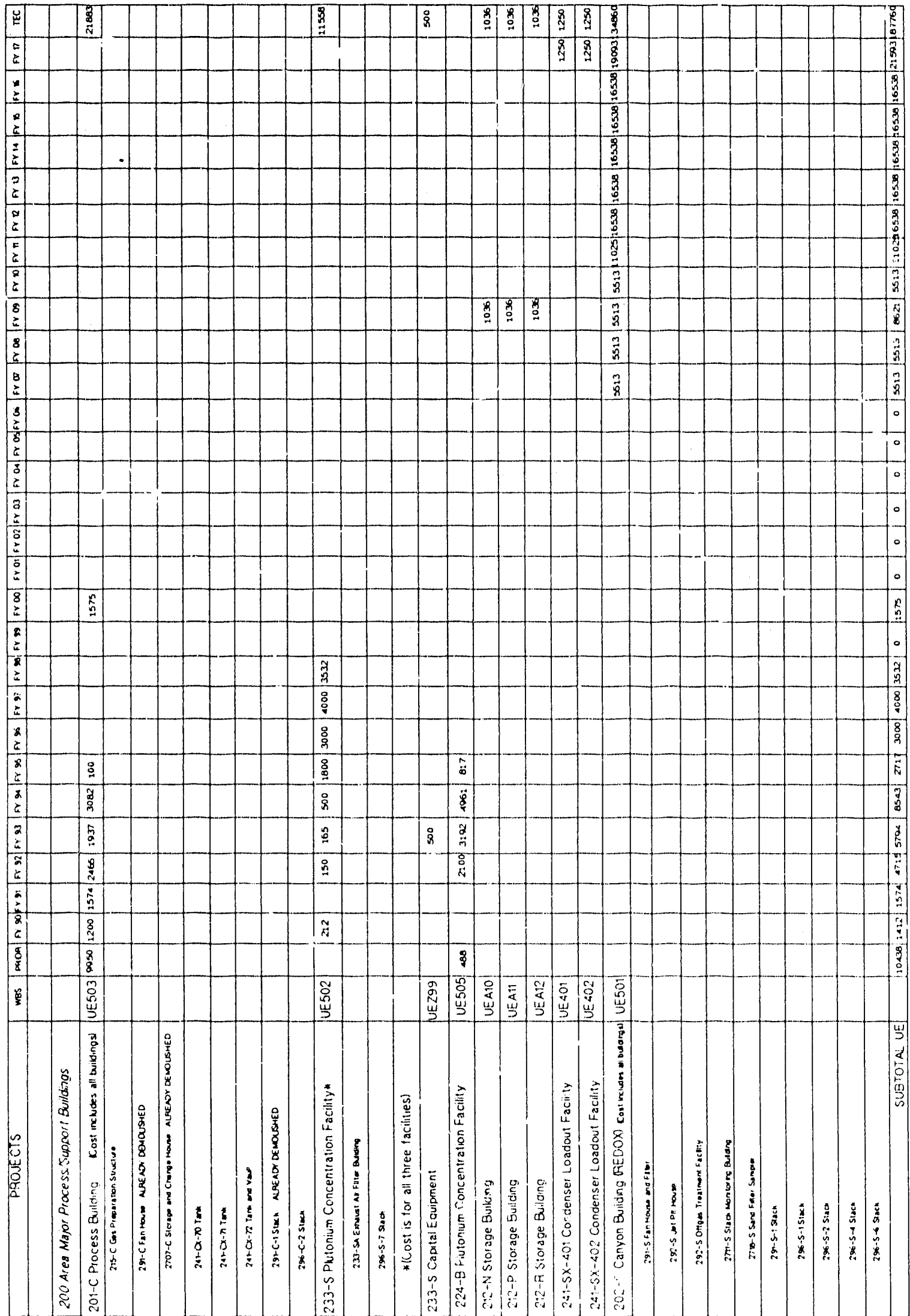


Table 1. Hanford Decommissioning Baseline Long-Range Projection. $(\$ 000)$ (sheet 6 of 7 )

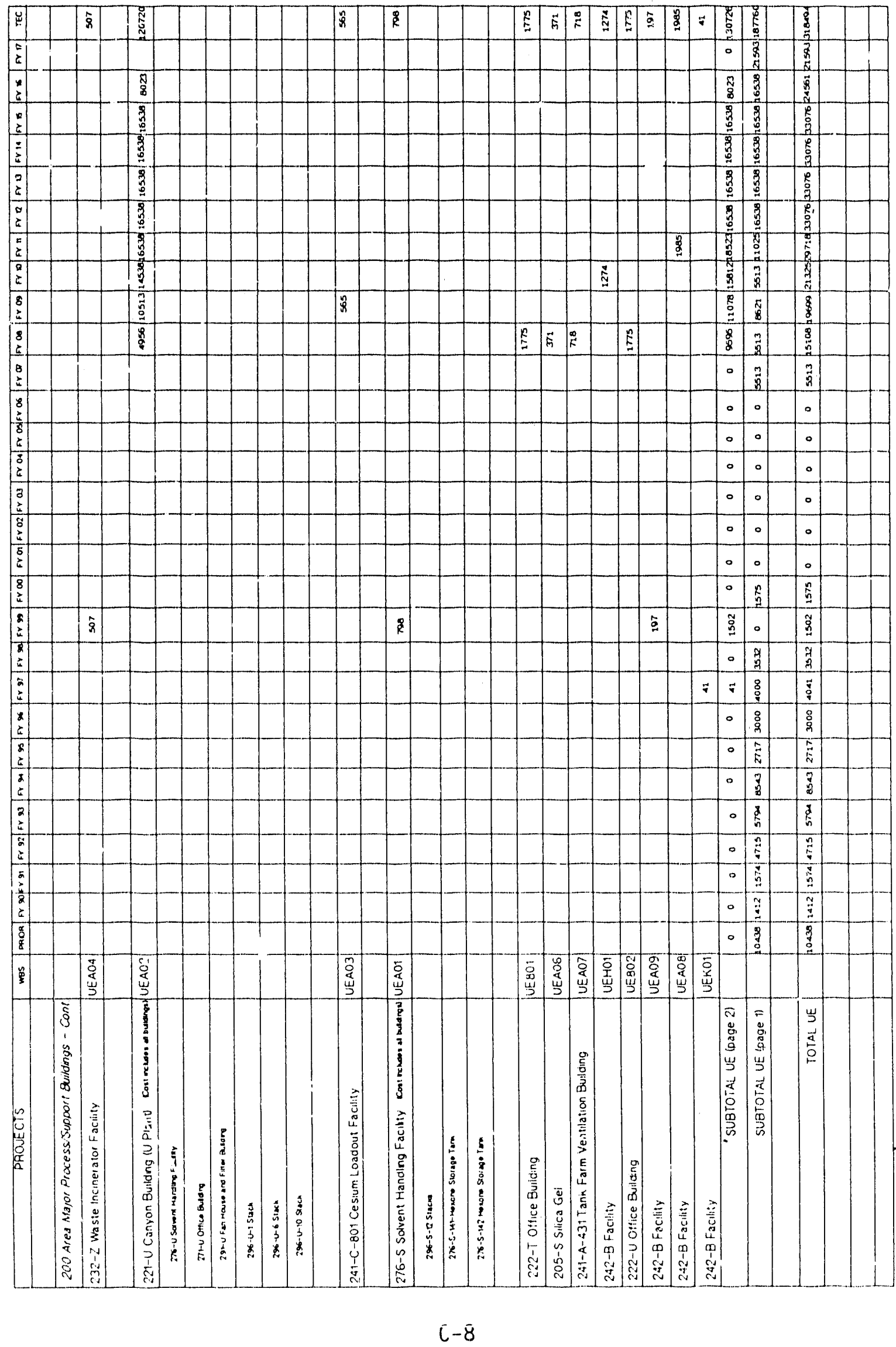


Table 1. Hanford Decommissioning Baseline Long-Range Projection. $(\$ 000)$ (sheet 7 of 7 )

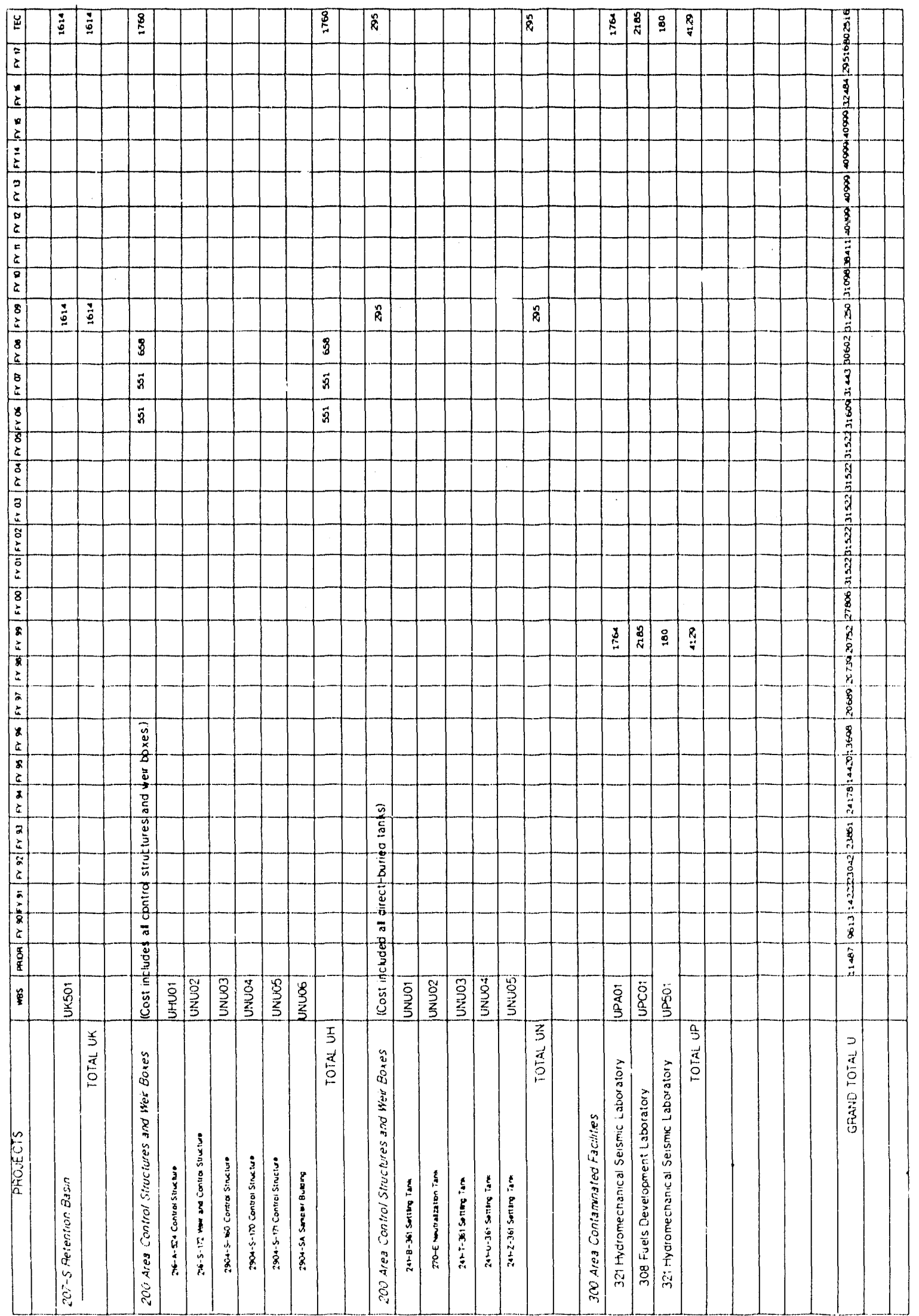



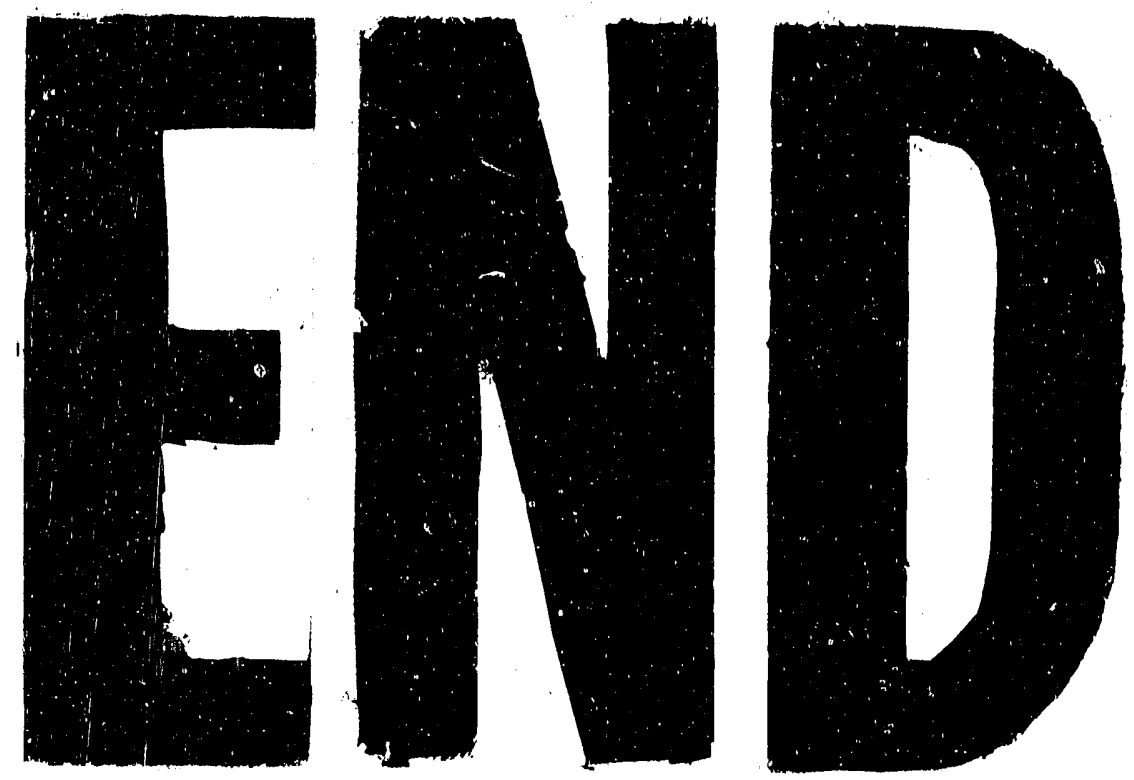

4
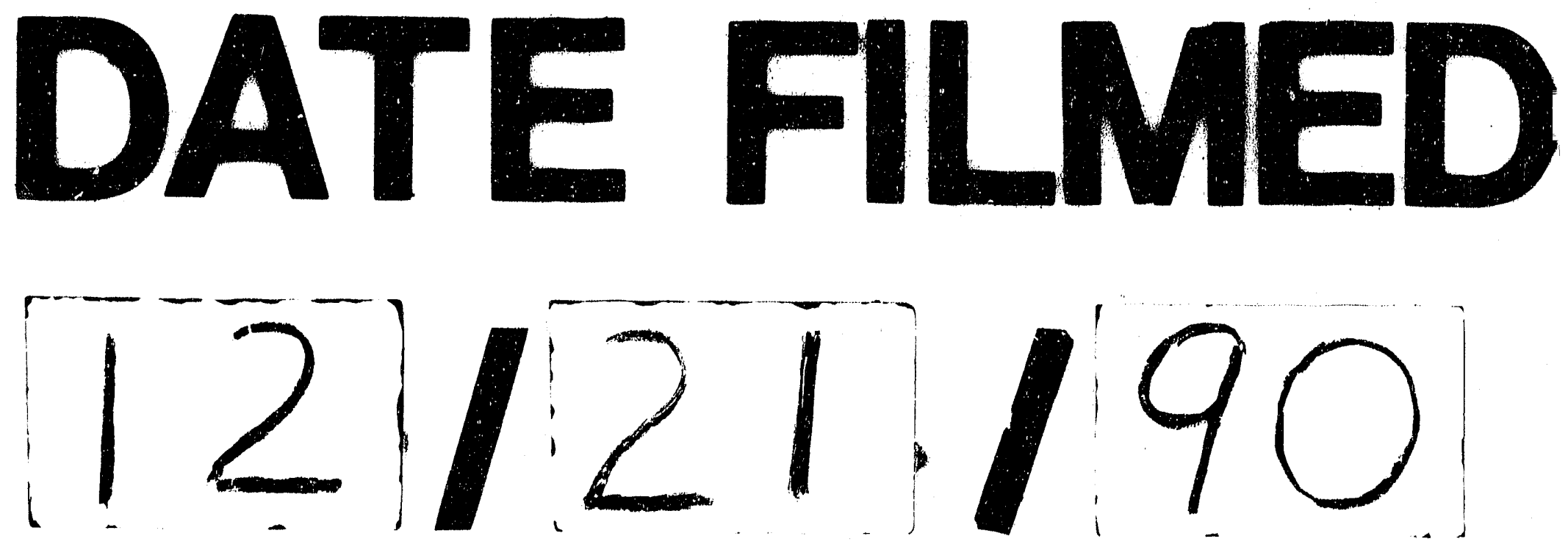
